
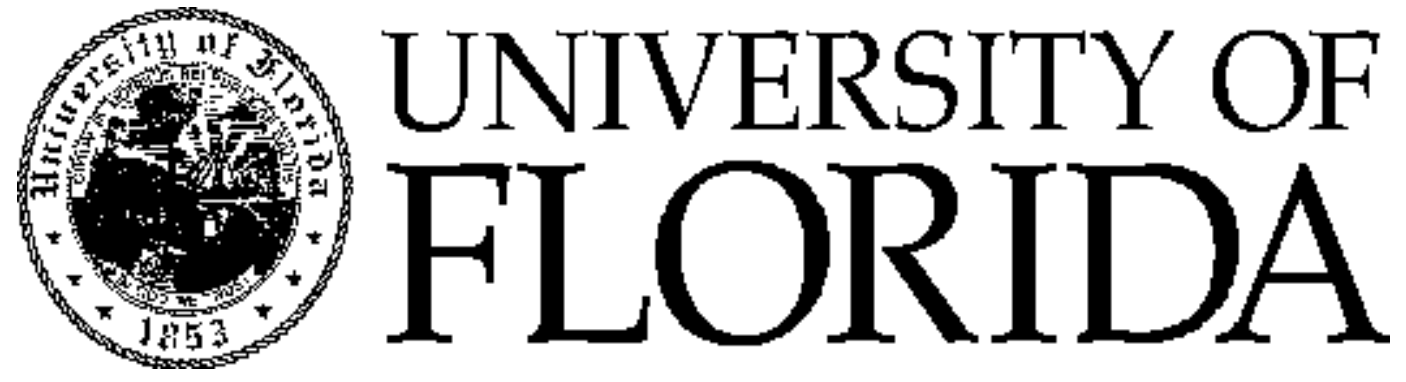

\title{
Market Development Strategies for the Florida Tropical Fruit Industry
}

Florida Agricultural Market Research Center Industry Report 97-2

December 1997

\author{
by \\ Robert L. Degner \\ Susan D. Moss \\ Jonathan H. Crane
}

Submitted to the Florida Department of Agriculture and Consumer Services

by the Florida Agricultural Market Research Center

Food and Resource Economics Department

Institute of Food and Agricultural Sciences

University of Florida, Gainesville, FL 32611 


\section{PREFACE}

The extensive fieldwork required for this project was began in 1994 and was completed in early 1996. Because of tropical fruit grower and shipper interest, results of the on-going research were released piecemeal through several conferences, associated proceedings, journal articles, and a draft report in mid-1996. These materials, submitted to the Florida Department of Agriculture and Consumer Services and the USDA's Federal State Market Improvement Program (FSMIP), met the required reporting requirements. This report has been prepared to fill the continuing need for one comprehensive reference covering all phases of this tropical fruit marketing research. 


\begin{abstract}
Telephone surveys of tropical fruit growers and shippers in south Florida and of major food retailers and specialty produce wholesalers nationwide were conducted to determine availability, sales trends, and market development strategies for 11 tropical fruits selected by Florida Tropical Fruit Growers of South Florida, Inc., on the basis of their commercial potential. The fruits targeted were mangos, carambola, lychee, papaya, mamey sapote, specialty bananas, longan, guava, passion fruit, atemoya, and sugar apples. The grower-shipper survey revealed no major changes in the production of most fruits in the wake of Hurricane Andrew although modest increases were anticipated for lychees, longans, and papayas. Mangos, papayas, and carambolas were found to be widely available at wholesale and retail levels, and sales trends were generally positive. However, the remaining fruits had varying degrees of availability at wholesale and retail levels. Some fruits, such as mamey sapote, atemoya, and sugar apples had very limited distribution, particularly west of the Mississippi River because of phytosanitary restrictions. Retail and wholesale produce buyers generally agreed that the greatest impediments to increased sales of tropical fruit from Florida were (1) lack of consumer familiarity and awareness, (2) high prices relative to other types of fruit, and (3) supply problems, such as limited or inconsistent supplies and short production seasons. This paper analyzes marketing suggestions made by the trade and makes specific recommendations for improved marketing programs for south Florida's tropical fruit growers and shippers.
\end{abstract}




\title{
FLORIDA AGRICULTURAL MARKET RESEARCH CENTER
}

The Florida Agricultural Market Research Center is a service of the Food and Resource Economics Department. Its purpose is to provide timely, applied research on current and emerging marketing problems affecting Florida's agricultural and marine industries. A basic goal of the Center seeks to provide marketing research and related information to producer organizations, trade associations, and governmental agencies concerned with improving and expanding markets for Florida's agricultural and marine producers.

Client organizations are required to pay direct costs associated with their research projects. Such costs include labor for personnel and telephone interviewing, mail surveys, travel, and computer analyses. Professional time and support is provided to organized producer groups at no charge by IFAS.

Professional agricultural economists with specialized training and experience in marketing participate in every Center project. Cooperating personnel from other IFAS units are also involved whenever specialized technical assistance is needed.

\author{
Dr. Robert L. Degner, Director \\ Florida Agricultural Research Center \\ 1083 McCarty Hall \\ University of Florida \\ Gainesville, Florida 32611-0240 \\ (352) 392-1871 (Voice) \\ (352) 392-1886 (Fax) \\ DEGNER@FRED.IFAS.UFL.EDU (E-mail)
}




\section{ACKNOWLEDGMENTS}

We express our appreciation to the Florida Department of Agriculture and Consumer Services and the United States Department of Agriculture, Agricultural Marketing Service, for providing major funding for this project. We are also deeply indebted to Dr. Carlos Balerdi, Dade County Extension Agent (Tropical fruit specialist) for invaluable assistance throughout the project. We are also grateful to Noble Hendrix, tropical fruit grower and shipper, for his suggestions during the formative stages of the project. Thanks are also due to the Board of Directors of Tropical Fruit Growers of South Florida, Inc., for their assistance in clarifying the objectives of this study and for enlisting the cooperation of their members, whose assistance was invaluable. We also thank the publisher and staff of The Blue Book for helping to identify specialty produce wholesalers throughout the U.S. for the wholesale trade survey.

We appreciate the dedication and hard work of our Research Assistants, Lisa Mazak Demmy and Stephanie Shephard, in conducting the interviews of tropical fruit growers, retailers and wholesalers upon which this report is based. We also acknowledge and appreciate the help of Kim Langedyk in researching and writing much of the section dealing with cultural characteristics of Asian and Hispanic consumers.

Finally, gratitude is expressed to Thurston L. Brooks for his graphics expertise and to Vivian Thompson for typing much of the final manuscript. 


\section{TABLE OF CONTENTS}

PREFACE $\ldots \ldots \ldots \ldots \ldots \ldots \ldots \ldots \ldots \ldots \ldots \ldots \ldots \ldots \ldots \ldots \ldots \ldots \ldots \ldots$

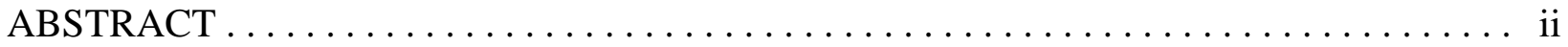

FLORIDA AGRICULTURAL MARKET RESEARCH CENTER $\ldots \ldots \ldots \ldots \ldots \ldots \ldots \ldots$ iii

ACKNOWLEDGMENTS $\ldots \ldots \ldots \ldots \ldots \ldots \ldots \ldots \ldots \ldots \ldots \ldots \ldots \ldots \ldots \ldots \ldots$

TABLE OF CONTENTS $\ldots \ldots \ldots \ldots \ldots \ldots \ldots \ldots \ldots \ldots \ldots \ldots \ldots \ldots \ldots \ldots$

LIST OF TABLES $\ldots \ldots \ldots \ldots \ldots \ldots \ldots \ldots \ldots \ldots \ldots \ldots \ldots \ldots \ldots \ldots \ldots \ldots \ldots \ldots \ldots$

LIST OF FIGURES $\ldots \ldots \ldots \ldots \ldots \ldots \ldots \ldots \ldots \ldots \ldots \ldots \ldots \ldots \ldots \ldots \ldots \ldots \ldots$

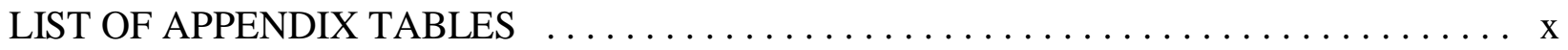

EXECUTIVE SUMMARY $\ldots \ldots \ldots \ldots \ldots \ldots \ldots \ldots \ldots \ldots \ldots \ldots \ldots \ldots \ldots \ldots \ldots$

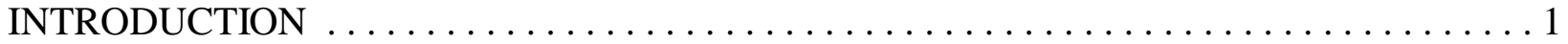

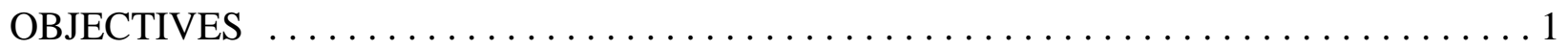

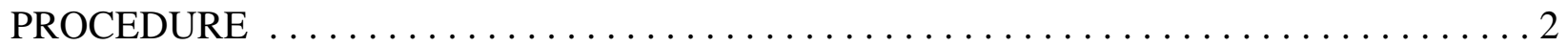

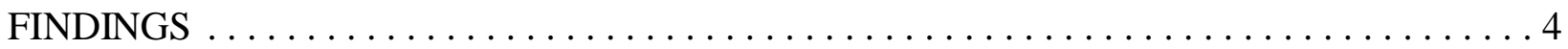

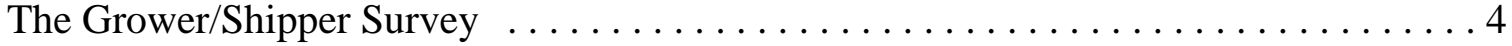

Pre- and Post Hurricane Acreages $\ldots \ldots \ldots \ldots \ldots \ldots \ldots \ldots \ldots$

Comments Regarding Marketing Problems . . . . . . . . . . . . . . . 7

Marketing Tropical Fruits to Asian and Hispanic Consumers . . . . . . . . . . . . . 9

Major Asian and Hispanic Markets . . . . . . . . . . . . . . . . . 9

Location of Top 25 Hispanic and Asian U.S. Market Regions . . . . . . . . . . 12

General Cultural Attributes of Asians and Hispanics . . . . . . . . . . . . 14

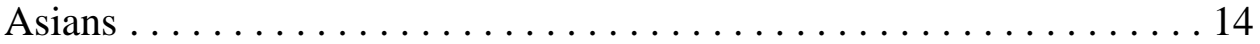

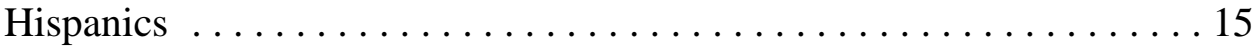

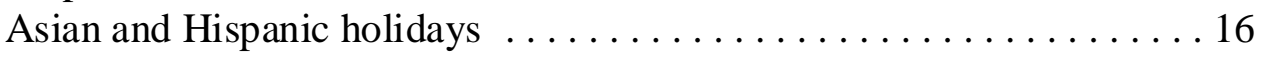

The Chain Supermarket Survey . . . . . . . . . . . . . . . . . . . . . . 19

Availability of Selected Tropical Fruits in Major Supermarkets . . . . . . . . . 19

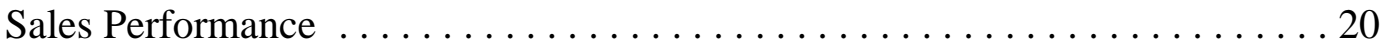

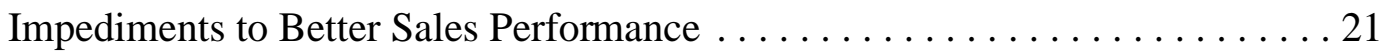

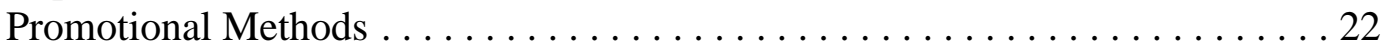




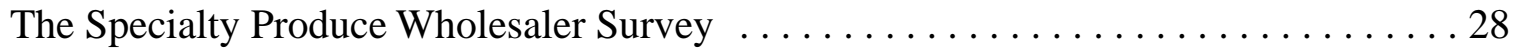

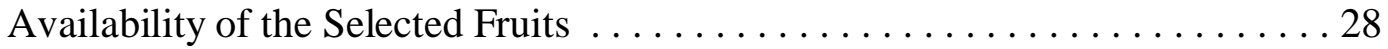

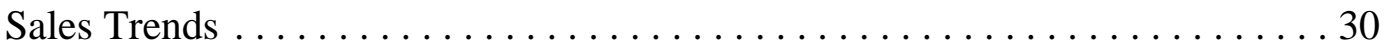

Wholesalers' Geographic Sources and Quality Ratings of Selected Fruits . . . 31

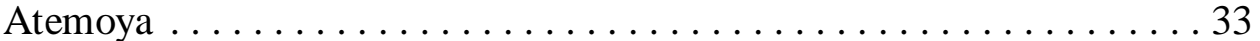

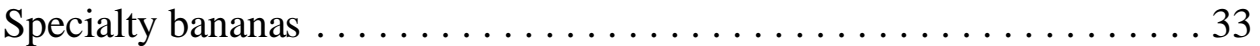

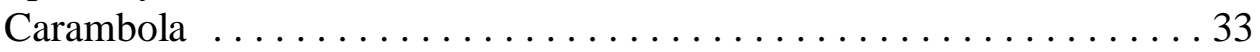

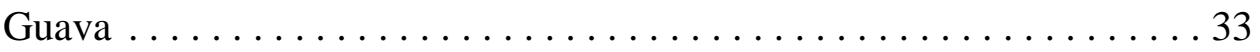

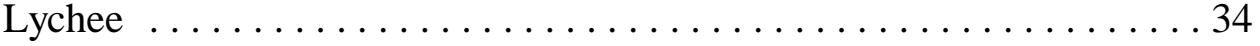

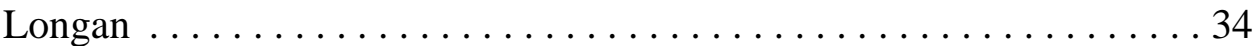

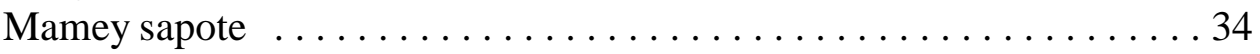

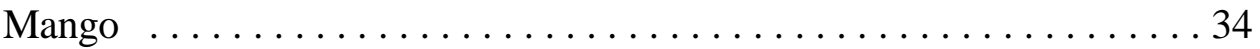

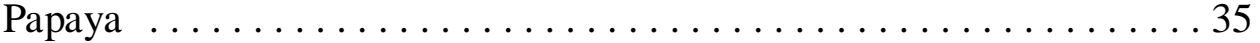

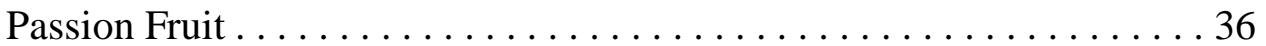

Sugar apple . . . . . . . . . . . . . . . . . 36

Wholesalers' Suggestions for Improving South Florida's Tropical Fruit Sales . . 36

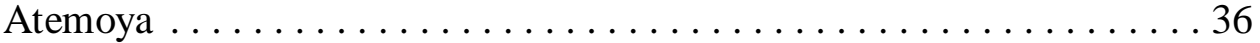

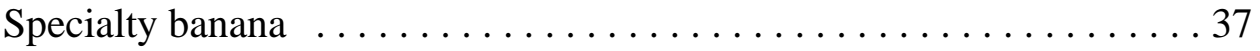

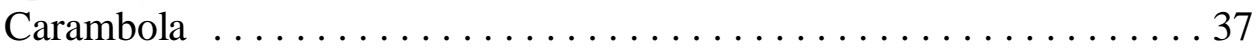

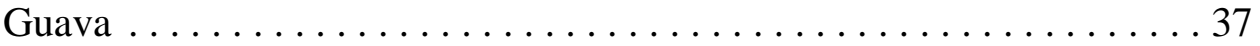

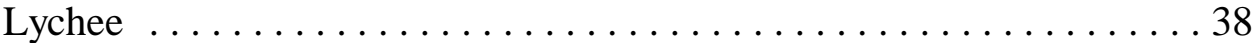

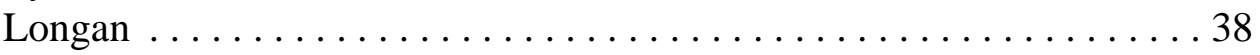

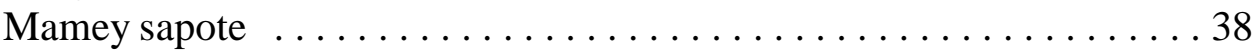

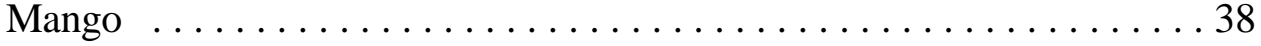

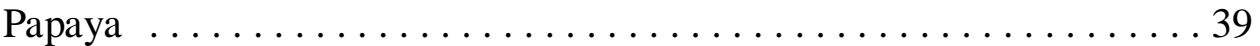

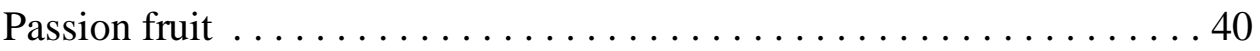

Sugar apple ...................... 40

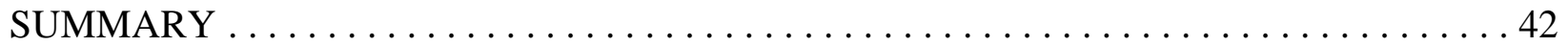

CONCLUSIONS AND RECOMMENDATIONS $\ldots \ldots \ldots \ldots \ldots \ldots \ldots \ldots \ldots \ldots \ldots . \ldots 47$

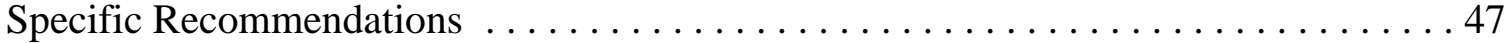

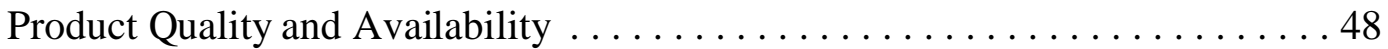

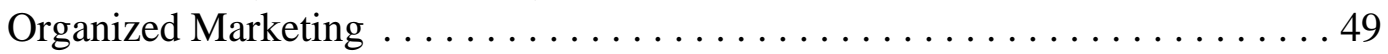

Contracts with existing firms . . . . . . . . . . . . . 49

Marketing orders ......................... 49

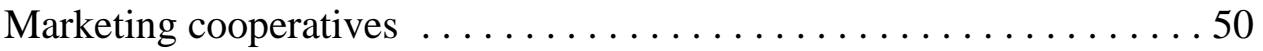

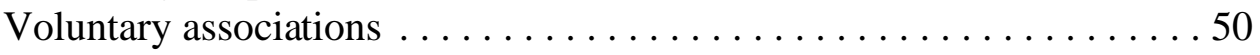

Market Development: Geographic Considerations . . . . . . . . . . . . 51

Development Activities for Traditional Commercial Markets . . . . . . . . 52

Educational programs and materials directed to the produce trade . . . 5 52

Educational programs and promotional materials directed to

consumers ........................... 54

Direct Marketing: An alternative to the traditional commercial 


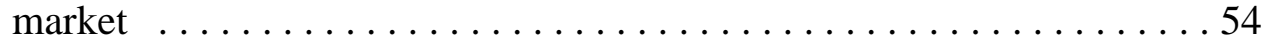

Concluding Observations: Opportunities and Challenges $\ldots \ldots \ldots \ldots \ldots 56$

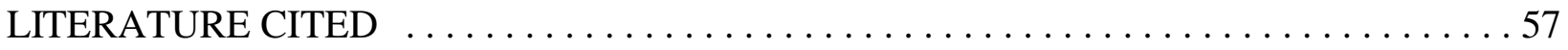

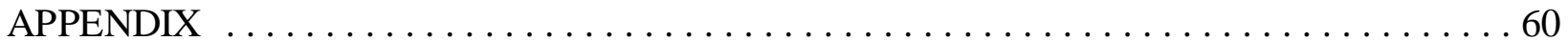




\section{LIST OF TABLES}

Table 1. Pre- and post-hurricane acreage and production estimates for selected tropical

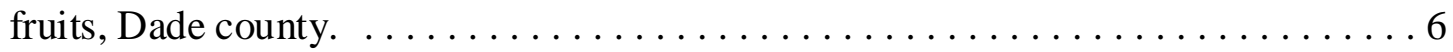

Table 2. Growers' and shippers' expressed needs with respect to marketing tropical fruit. . . . 8

Table 3. Top 25 Asian and top 25 Hispanic market areas ..................... 9

Table 4. Resident population of the United States by race and Hispanic origin compared with the population of the thirty cities targeted for ethnic Asian and Hispanic populations ....................................... 10

Table 5. Ethnic detail, aggregated for the top 25 Asian markets. ................ 13

Table 6. Ethnic detail, aggregated for the top 25 Hispanic markets. ............... 14

Table 7. Summary of major Asian holidays where food is important, by month and tropical fruit availability. .................................... 17

Table 8. Summary of major Hispanic holidays where food is important by month and tropical fruit availability . . . . . . . . . . . . . . . . . . . . . 18

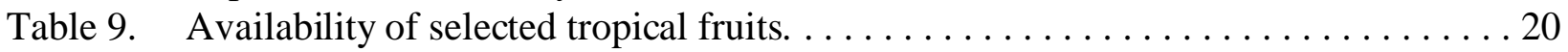

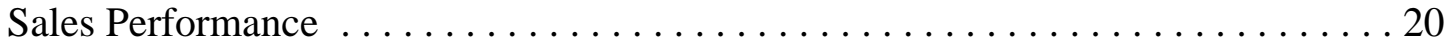

Table 10. Sales performance of selected tropical fruit. ..................... 20

Table 11. Chain supermarket buyers perceptions that tropical fruit is too expensive. . . . . 21 21

Table 12. Promotional activities reported used for tropical fruit by chainstores, $1994-95 \ldots 2.23$

Table 13. Promotional methods and materials recommended for tropical fruits by supermarket chain produce executives, aided recall. ................ 24

Table 14. Price card sizes preferred by supermarkets. ................... 25

Table 15. Miscellaneous methods for improving sales of Florida-produced tropical fruit, as recommended by product executives of supermarket chains, open-ended

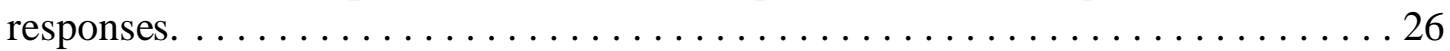

Table 16. The number of chainstore produce executives unfamiliar with selected tropical

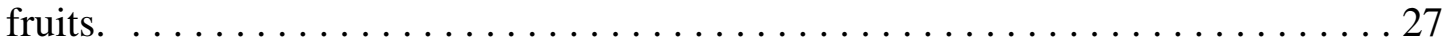

Table 17. Number of specialty wholesalers handling targeted fruits. . . . . . . . . . 29

Table 18. Sales trends for targeted fruits, reported by specialty produce wholesalers. . . . . . 31

Table 19. Wholesalers' ratings of sources of fruit. . . . . . . . . . . . . . . . . 32

Table 20. Specialty produce wholesalers' suggestions for improving sales of selected

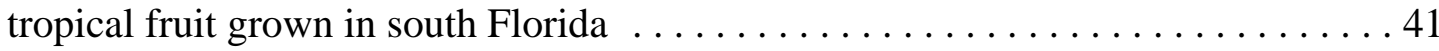




\section{LIST OF FIGURES}

Figure 1. Population growth, by race or ethnicity, $1980-1989 \ldots \ldots \ldots \ldots \ldots \ldots$

Figure 2. Median household income, by race or ethnicity, $1988 \ldots \ldots \ldots \ldots \ldots \ldots 11$

Figure 3. Hispanic population growth, $1980-2000 \ldots \ldots \ldots \ldots \ldots \ldots \ldots \ldots \ldots$

Figure 4. MSAs with the greatest concentration of Asians, ranked, $1994 \ldots \ldots \ldots \ldots 12$

Figure 5. MSAs with the greatest concentration of Hispanics, ranked, $1994 \ldots \ldots$. . . . 12 


\section{LIST OF APPENDIX TABLES}

Appendix Table A-1. Estimates of pre-hurricane sales distributions for selected tropical fruits, Dade County, Florida, in percentages . . . . . . . . . . 61

Appendix Table A-2. Estimates of post-hurricane sales distribution for selected tropical fruits, Dade County, Florida, in percentages . . . . . . . . 62

Appendix Table A-3. Estimates of post-hurricane sales distributions for selected tropical fruits, Dade County, Florida, in pounds .............. 63

Appendix Table A-4. Number of growers and shippers, estimated production at maturity for plantings as of 12-31-94, and volume of production self-packed and shipped by type of fruit $\ldots \ldots \ldots \ldots \ldots \ldots \ldots \ldots 64$

Appendix Table B-1. Top 25 Hispanic and Asian U.S. Market Regions …........ 65 Appendix Table B-2. Distribution of Chinese population by city $\ldots \ldots \ldots \ldots \ldots \ldots 70$ Appendix Table B-3. Distribution of Filipino population by city $\ldots \ldots \ldots \ldots \ldots \ldots 71$ Appendix Table B-4. Distribution of Asian Indian population by city . . . . . . . . . 72 Appendix Table B-5. Distribution of Korean population by city $\ldots \ldots \ldots \ldots \ldots \ldots 73$ Appendix Table B-6. Distribution of Japanese population by city . . . . . . . . . . . 74 Appendix Table B-7. Distribution of Vietnamese population by city . . . . . . . . . 75 Appendix Table B-8. Distribution of Mexican population by city ............. 76 Appendix Table B-9. Distribution of Puerto Rican population by city . . . . . . . . . 77 Appendix Table B-10. Distribution of Cuban population by city $\ldots \ldots \ldots \ldots \ldots \ldots 78$ Appendix Table B-11. Distribution of Salvadoran population by city $\ldots \ldots \ldots \ldots \ldots 79$ Appendix Table B-12. Distribution of Dominican population by city $\ldots \ldots \ldots \ldots \ldots 80$ Appendix Table B-13. Distribution of Colombian population by city $\ldots \ldots \ldots \ldots \ldots 81$ Appendix Table B-14. Asian market region 1, Los Angeles, Ethnic detail .......... 82 Appendix Table B-15. Asian market region 2, San Francisco, Ethnic detail . . . . . . . . 82 Appendix Table B-16. Asian market region 3, New York, Ethnic detail . . . . . . . . 83 Appendix Table B-17. Asian market region 4, Chicago, Ethnic detail ............ 83 Appendix Table B-18. Asian market region 5, Baltimore/Washington, Ethnic detail . . . 84 Appendix Table B-19. Asian market region 6, Fresno, Ethnic detail . . . . . . . . . . 84 Appendix Table B-20. Asian market region 7, Seattle, Ethnic detail . ............ 85 Appendix Table B-21. Asian market region 8, Boston, Ethnic detail ............. 85 Appendix Table B-22. Asian market region 9, Houston, Ethnic detail ............ 86 Appendix Table B-23. Asian market region 10, Philadelphia, Ethnic detail . . . . . . . 86 Appendix Table B-24. Asian market region 11, Dallas, Ethnic detail . . ........... 87 Appendix Table B-25. Asian market region 12, Portland, Ethnic detail . . . . . . . . . 87 Appendix Table B-26. Asian market region 13, Minneapolis, Ethnic detail . . . . . . . . 88 Appendix Table B-27. Asian market region 14, Detroit, Ethnic detail . . . . . . . . . . 88 Appendix Table B-28. Asian market region 15, Tampa, Ethnic detail . ............ 89 Appendix Table B-29. Asian market region 16, Charlotte, Ethnic detail . . . . . . . . . 89 Appendix Table B-30. Asian market region 17, Denver, Ethnic detail . . . . . . . . . 90 Appendix Table B-31. Asian market region 18, Atlanta, Ethnic detail ............ 90 Appendix Table B-32. Asian market region 19, Cincinnati, Ethnic detail .......... 91 
Appendix Table B-33. Asian market region 20, Hartford, Ethnic detail . . . . . . . . . 91

Appendix Table B-34. Asian market region 21, Miami, Ethnic detail . . . . . . . . . 92

Appendix Table B-35. Asian market region 22, Phoenix, Ethnic detail . . . . . . . . . 92

Appendix Table B-36. Asian market region 23, Richmond, Ethnic detail . . . . . . . . 93

Appendix Table B-37. Asian market region 24, San Antonio, Ethnic detail . . . . . . . . . 93

Appendix Table B-38. Asian market region 25, Milwaukee, Ethnic detail . . . . . . . . . . 94

Appendix Table B-39. Hispanic market region 1, Los Angeles, Ethnic detail . . . . . . . 95

Appendix Table B-40. Hispanic market region 2, New York, Ethnic detail . . . . . . . . 95

Appendix Table B-41. Hispanic market region 3, San Antonio, Ethnic detail . . . . . . . . 96

Appendix Table B-42. Hispanic market region 4, Albuquerque, Ethnic detail . . . . . . . 96

Appendix Table B-43. Hispanic market region 5, San Francisco, Ethnic detail . . . . . . . 97

Appendix Table B-44. Hispanic market region 6, Miami, Ethnic detail . . . . . . . . . . 97

Appendix Table B-45. Hispanic market region 7, Chicago, Ethnic detail . . . . . . . . 98

Appendix Table B-46. Hispanic market region 8, Houston, Ethnic detail . . . . . . . . 98

Appendix Table B-47. Hispanic market region 9, Fresno, Ethnic detail . . . . . . . . . . . 99

Appendix Table B-48. Hispanic market region 10, Phoenix, Ethnic detail . . . . . . . . . 99

Appendix Table B-49. Hispanic market region 11, Dallas, Ethnic detail . . . . . . . . . 100

Appendix Table B-50. Hispanic market region 12, Denver, Ethnic detail . . . . . . . . 100

Appendix Table B-51. Hispanic market region 13, Tampa, Ethnic detail . . . . . . . . 101

Appendix Table B-52. Hispanic market region 14, Boston, Ethnic detail . . . . . . . . 101

Appendix Table B-53. Hispanic market region 15, Baltimore/Washington, Ethnic

detail . . . . . . . . . . . . . . . . . . . . . 102

Appendix Table B-54. Hispanic market region 16, Hartford, Ethnic detail . . . . . . . 102

Appendix Table B-55. Hispanic market region 17, Philadelphia, Ethnic detail . . . . . . 103

Appendix Table B-56. Hispanic market region 18, Seattle, Ethnic detail . . . . . . . . . 103

Appendix Table B-57. Hispanic market region 19, Salt Lake City, Ethnic detail . . . . . . 104

Appendix Table B-58. Hispanic market region 20, Portland, Ethnic detail . . . . . . . 104

Appendix Table B-59. Hispanic market region 21, Detroit, Ethnic detail . . . . . . . 105

Appendix Table B-60. Hispanic market region 22, Kansas City, Ethnic detail . . . . . . 105

Appendix Table B-61. Hispanic market region 23, Milwaukee, Ethnic detail . . . . . . 106

Appendix Table B-62. Hispanic market region 24, Scranton/Harrisburg, Ethnic

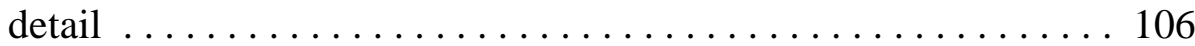

Appendix Table B-63. Hispanic market region 25, Oklahoma City, Ethnic detail . . . . . 107

Appendix Table B-64. Calendar of fruit availability and Asian holidays. . . . . . . . . 108

Appendix Table B-65. Calendar of fruit availability and Hispanic holidays . . . . . . . . 112

Appendix Table C-1. Chainstore produce executives' comments on atemoya, 75 firms,

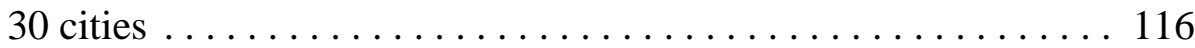

Appendix Table C-2. Chainstore produce executives' comments on specialty bananas,

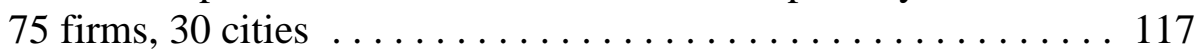

Appendix Table C-3. Chainstore produce executives' comments on carambola, 75 firms,

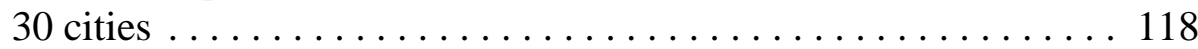

Appendix Table C-4. Chainstore produce executives' comments on guava, 75 firms,

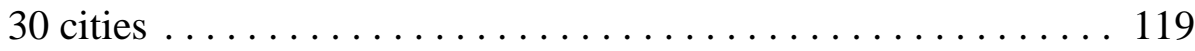

Appendix Table C-5. Chainstore produce executives' comments on lychee, 75 firms, 
30 cities ............................... 120

Appendix Table C-6. Chainstore produce executives' comments on longan, 75 firms,

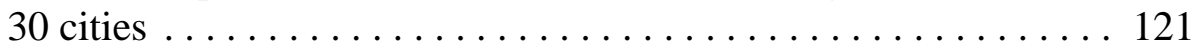

Appendix Table C-7. Chainstore produce executives' comments on mamey sapote, 75 firms, 30 cities . . . . . . . . . . . . . . . . . . . 122

Appendix Table C-8. Chainstore produce executives' comments on mango, 75 firms, 30 cities ............................... 123

Appendix Table C-9. Chainstore produce executives' comments on papaya, 75 firms, 30 cities . . . . . . . . . . . . . . . . . . . . . . . 124

Appendix Table C-10. Chainstore produce executives' comments on passion fruit, 75 firms, 30 cities . ......................... 125

Appendix Table C-11. Chainstore produce executives' comments on sugar apple, 75 firms, 30 cities . . . . . . . . . . . . . . . . . . . 126

Appendix Table D-1. Phytosanitary restrictions resulting from the Caribbean Fruit Fly on selected tropical fruit shipments to California, Texas and Arizona ................................. 127

Appendix Table D-2. Sales trends reported by specialty produce wholesalers for selected tropical fruits by U.S. region . . . . . . . . . . . . . . . 128

Appendix Table D-3. Wholesalers' sources of specialty tropical fruits, by fruit . . . . . 129 


\section{EXECUTIVE SUMMARY}

This study examines tropical fruit production and marketing in south Florida.

The purpose of the study was to improve the efficiency of the marketing system for tropical fruits and to formulate viable market development strategies for 11 selected fruits thought to have the greatest commercial potential. These fruits were mangos, carambola, lychee, papaya, mamey sapote, specialty bananas, longan, guava, passion fruit, atemoya and sugar apple.

The 11 fruits were selected by the board of directors of Tropical Fruit Growers of South Florida, Inc., an organization comprised largely of growers, shippers and horticulturists interested in developing and promoting south Florida's tropical fruit industry.

To meet the study's objectives, three telephone surveys were conducted: a survey of tropical fruit growers and shippers in south Florida, a survey of produce buyers of major food retailers in geographic areas of the U.S. containing the 25 highest concentrations of Asian and Hispanic residents, and a survey of specialty produce wholesalers throughout the U.S.

The grower shipper survey revealed that total tropical fruit acreage at the end of 1994 was about 35 percent below pre-Hurricane Andrew levels dropping from approximately 20,000 to 13,000 acres.

* The grower survey showed some acreage shifts, but none that would require major redirection of marketing activities or investments in marketing infrastructure.

* Census of population data were used to identify the largest concentrations of Asian and Hispanic residents. The greatest numbers of Asians were found to be in the populous northeast, the industrial cities of the upper midwest, major urban centers in Texas and on the Pacific west coast. Relatively large numbers of Hispanics were also found in urban centers of the northeast, upper midwest and west coast. Large numbers of Hispanics were also located in Florida and southwestern regions of the U.S., including Texas, Oklahoma, New Mexico, Arizona, and Colorado.

Ethnic detail within the Asian and Hispanic populations were also identified by prevailing grocery distribution regions. Shippers can use this information to identify markets and plan timely, effective promotions geared to cultural attributes and holidays of specific ethnic subgroups within Asian and Hispanic populations.

The survey of chainstore produce buyers in the grocery distribution regions containing the largest concentrations of Asian and Hispanic residents indicated almost universal availability for mangos, papayas and carambolas. Sales performance of these fruits was also rated favorably by most buyers. Passion fruit, guavas, specialty bananas and lychees were 
available on a regular (or seasonal) basis in about half to two-thirds of all stores. However, sales were rated as "poor" by 60 to 80 percent of the respondents. Atemoyas, mamey sapotes, longans and sugar apples were typically available in less than one-third of the chainstores, and sales ratings were also relatively poor.

Chainstore buyers identified four basic impediments to greater sales volume of the 11 tropical fruits. These were (1) lack of consumer awareness, mentioned by 40 to 70 percent of the buyers, depending on the fruit, (2) relatively high prices, mentioned by 15 to 20 percent (3) supply problems or inconsistent supplies and short production seasons, three to 20 percent and (4) low product quality. Fortunately, complaints about product quality were minimal for most of the 11 fruits.

About 20 percent of the chainstore retailers used no promotional materials or activities for tropical fruit other than basic product identification. Newspaper ads, in-store demonstrations, price specials, special displays, recipes and "tropical theme" promotions for multiple kinds of fruit were the most frequently used and most highly rated activities.

* There was considerable retailer interest in price cards, posters, in-store demonstrations and recipes. Retailers favored relatively small price cards, with 7" x 11" being the most requested size. Ninety percent of the retailers using price cards from outside sources wanted formats smaller than 80 square inches.

* About one-fourth of the retailers recommended that the Florida tropical fruit industry develop a promotional kit containing a variety of point-of-sale (POS) items such as price cards, recipes, posters and ad slicks.

* Several retailers suggested targeting the foodservice industry as a means of introducing and promoting tropical fruit to consumers.

* A few buyers admitted they were unfamiliar with some of the less common fruits; they recommended educational programs directed at the trade. Such activities could include trade shows, direct mail and product samples.

* Survey data from 145 specialty produce wholesalers throughout the U.S. showed almost universal availability of mangos and papayas. Carambolas were handled by about 60 percent of the wholesalers east of the Mississippi River (eastern region), and by only 40 percent of those west of the Mississippi (western region). The remaining fruits were available from fewer than half of the eastern firms, but distribution was far less common in the western region.

* The limited availability of many of the fruits in the western region is likely the result of phytosanitary restrictions in place to keep the Carribean fruit fly out of Texas, Arizona and California.

* Increased promotion was the most frequently mentioned market development strategy 
suggested by specialty produce wholesalers. Improved quality, i.e., less product damage and/or better varieties were also mentioned, particularly for mangos, passion fruit and papayas. Overcoming supply problems such as erratic availability and short seasons were also suggested for many of the fruits, but particularly for lychees and longans.

Both the retailer and wholesaler surveys discussed above showed limited distribution of many of the 11 target fruits. Taking an optimistic view, this indicates considerable potential. However, the firms that are not currently handling various tropical fruits have to be convinced to do so. A study by researchers at Cornell University found that supply availability, profit potential, nutritional information, vendor support, ripeness information, preparation and recipe information were important factors in deciding whether or not to carry a new item. Further, produce buyers felt that the burden of providing marketing and promotional information for new produce items rested on suppliers (51 percent) commodity organizations ( 28 percent) and national trade organizations ( 7 percent). Only 12 percent felt retailers were primarily responsible for such information.

* Our survey of specialty produce wholesalers found that few developed any type of educational or promotional materials for tropical fruit.

* If retailers and specialty produce wholesalers will not develop required educational and promotional materials, Florida growers and shippers must.

* The Florida tropical fruit industry has successfully leveraged its efforts through the Florida Department of Agriculture and Consumer Services (FDACS). Items such as the brochure "Tastes of the Tropics", the videotape "Tropical Fruit", and the tropical fruit section on the FDACS website will also provide considerable exposure for industry. However, more efforts are needed to provide immediate market development impact.

\section{Specific Recommendations}

* Consider organized marketing. A cohesive, organized approach would enhance growers' and shippers' marketing programs. There are many forms of organized marketing that could be considered, ranging from informal cooperation with other growers and shippers to highly structured and regulated organizations such as marketing orders and cooperatives.

* Address supply problems. Some fruits, particularly lychees, longans, atemoyas and sugar apples are particularly and adversely affected by short marketing seasons. New cultivars, cultural practices or storage technology should be explored to extend the seasonal availability of high quality fruit.

* Develop educational programs and materials directed at the produce trade. Trade shows are an effective means of reaching large numbers of produce professionals. Product samples can be used to educate buyers and entice them to carry unfamiliar items. Fruit availability 
calendars can serve as effective reminders of seasonal supplies. Buyers also need information on handling, such as storage temperatures, packaging, and expected shelf-life. They can also benefit from suggestions of tie-in items which can increase profitability.

The produce trade also needs consumer information such as ripening techniques, preparation methods and recipes.

Reach the produce trade through display contests, paid advertising in trade periodicals, trade directories, direct mail, faxes, e-mail and videotapes.

Develop a promotional kit containing price cards, shelf talkers, recipes, nutritional brochures, posters and ad slicks.

Target specialty produce wholesalers and retailers in areas with large numbers of Asian and Hispanic residents. Many are already familiar with tropical fruits, which can reduce educational costs.

Target eastern U.S. markets to avoid quality problems caused by fruit fly control measures, if applicable. Further, markets closer to Florida can reduce transportation time and perhaps some damage in transit. Quicker delivery can effectively extend shelf life of fragile fruit.

Improve packaging and labeling. Explore use of alternative packaging materials such as clear plastic clam shell packs. Such packages can prevent fruit damage, add value to retailers by reducing handling time, and showcase the fruit in the store. Labels with "selling words", UPC or PLU numbers and information useful to consumers also add value to retailers.

Develop educational and promotional materials and programs directed to consumers. Instore demonstrations are particularly effective, but point-of-sale materials such as price cards, posters, die-cuts, brochures, recipes and videotapes are also useful. A tropical fruit "website" on the internet which features all readily available tropical fruits can provide tremendous exposure for the tropical fruit industry and to individual firms.

* Consider alternative market channels such as direct marketing to consumers via the internet, traditional mail order utilizing catalogues or brochures, and local greenmarkets (farmer's markets).

In conclusion, the marketing environment for tropical fruits is very positive at present. Consumption of fresh fruits has been steadily increasing over the past several decades and is currently at record levels, fueled by consumers' growing awareness of health benefits associated with fresh produce and increased purchasing power. Further, the outlook for marketing tropical fruits is particularly bright because of growing ethnic populations and consumers' willingness to try "new", exotic items. Market development activities undertaken under these positive conditions have excellent potential for paying great dividends. 


\section{INTRODUCTION}

South Florida is one of the few areas within the continental U.S. where a wide variety of tropical fruits can be grown commercially. Avocados, limes, mangoes, carambola (star fruit), bananas, papaya, mamey sapote, and lychee are the leading fruit crops, but more than two dozen additional exotic tropical species are also produced (Degner, Mack and Moss, 1995).

On August 24, 1992, Hurricane Andrew ravaged the principal production area in the southern portion of Dade County. Approximately 40 percent of all tropical fruit acreage was destroyed and the remaining acreage was heavily damaged. The three fruit crops with the largest acreages, avocados, limes, and mangoes, also suffered the greatest losses. A March 1993 tree inventory revealed a loss of nearly 3,000 acres of avocados, over 4,400 acres of limes, and over 1,000 acres of mangoes since the last official inventory was taken in 1990. On an acreage basis, this represented one-third of the 1990 avocados, two-thirds of the limes, and nearly 40 percent of the mangoes (Florida Agricultural Statistics Service, 1993).

The devastation wrought by Hurricane Andrew resulted in a tremendous disruption of Florida's tropical fruit industry. This research was undertaken to assist the tropical fruit industry in south Florida to take stock of their production potential in the aftermath of the hurricane and to develop improved marketing strategies for a wider variety of exotic tropical fruits.

\section{OBJECTIVES}

The basic objectives of this study were to improve the efficiency of the marketing system for tropical fruits and to formulate viable market development strategies for eleven selected fruits. Specific objectives were to:

(1) Delineate existing marketing channels for tropical fruits produced in south Florida and estimate the proportions of each type of fruit moving through each channel during pre- and post-hurricane periods.

(2) Identify geographic areas of the U.S. where the greatest concentrations of Asian and Hispanic populations are located and determine ways to increase sales of selected tropical fruits to Asian and Hispanic consumers.

(3) Identify the major chain supermarkets serving the Metropolitan Statistical Areas (MSAs) where the top twenty-five concentrations of Asian and Hispanic populations are located and determine ways to increase sales through these outlets.

(4) Identify specialty produce wholesalers throughout the U.S. and determine the potential for increasing sales of tropical fruit through these dealers.

(5) Determine the need for improved educational and promotional materials aimed at the trade and at consumers. 


\section{PROCEDURE}

The major emphasis of this research was on 11 selected tropical fruits. These fruits were chosen by the Board of Directors of the Florida Tropical Fruit Grower's Association, on the basis of commercial potential. The 11 fruits were mango (Mangifera indica), carambola (Averrhoa carambola), lychee (Litchi chinensis), papaya (Carica papaya), specialty bananas, mamey sapote (Pouteria sapota), guava (Psidium guajava), longan (Dimocarpus longan), passion fruit (Passiflora edulis \& p. edulis f. flavicarpa), atemoya (Annona cherimola $\times$ A. squamosa), and sugar apple (Annona squamosa). These fruits were featured in a promotional brochure entitled "Tastes of the Tropics" (Florida Department of Agriculture and Consumer Services, 1993).

Board members of the Tropical Fruit Grower's Association also suggested that the research seek ways to target Asian and Hispanic consumers. Based upon their experience in selling and shipping exotic produce, board members felt that Asians and Hispanics were likely to be familiar with many of the selected fruits, and that this familiarity would reduce the need for expensive educational programs.

To meet Objective 1, telephone interviews of commercial tropical fruit growers and packershippers in the south Florida growing region were conducted in the first six months of 1995. A sampling frame of growers was developed from Cooperative Extension Service contact and mailing lists, the membership roster of Tropical Fruit Growers' of South Florida, Inc., and grove owners identified on property tax rolls of the Dade County Tax Assessor's office. The original intent was to interview 50 growers and use a case study approach to describe the prevailing marketing channels and estimate their relative importance. However, after interviewing had begun, it quickly became evident that extreme variability among growers' and shippers' operations would require a much larger sample to provide meaningful results. Consequently, an effort was made to identify and interview the entire universe of tropical fruit growers. In total, 295 growers and shippers were identified and subsequently 245 were interviewed. This more extensive survey also allowed pre-hurricane and post-hurricane acreages (as of December 31, 1994) of all commercially significant tropical fruits to be estimated. These acreages, coupled with average tropical fruit yields, allowed estimation of total yields at maturity so that impending market development needs could be assessed.

Objectives 2 and 3 were addressed by analyzing U.S. Census data in conjunction with prevailing geographic food distribution patterns (U.S. Department of Census, 1990, Progressive Grocer, 1993). A leading trade directory, Progressive Grocer's Marketing Guidebook, was used to identify major food distribution regions throughout the U.S. Populations of Asians and Hispanics residing within each of the distribution regions were then obtained on a county-by-county basis from the 1990 Census of Population and aggregated for each region. The regions were then ranked by total numbers of Asians and total numbers of Hispanics, and the top 25 regions of each analyzed in greater detail and reported in sections below. Because many of the food distribution regions contain large numbers of both Asians and Hispanics, there was considerable overlap in the top 25 rankings. Thus, a total of 30 marketing regions were analyzed. 
Because of significant cultural differences among ethnic groups within the Asian and Hispanic categories, population statistics were reported for each ethnic subgroup as reported by the Census. For example, the Asian category was subdivided into 19 subcategories such as Chinese, Filipino, Asian Indian, Korean, etc. The Hispanic category was subdivided into 15 subgroups, including Mexican, Puerto Rican, Cuban, etc. Population statistics and rankings for each ethnic subgroup were reported for each of the 30 market regions to facilitate market development activities targeted to specific ethnic groups.

Once the 30 regions with the largest ethnic concentrations were identified, Progressive Grocer's Marketing Guidebook was used to determine the three largest chain supermarkets in each region. The head produce buyer in each firm was then sent a letter and a copy of the "Tastes of the Tropics" brochure to inform them of the study and lay the groundwork for a telephone interview. Approximately one week after the letters were sent, research assistants from the Florida Agricultural Market Research Center (FAMRC) contacted the head produce buyers by telephone. Usable data were obtained from 75 of the 90 firms.

The fourth objective was to identify specialty produce wholesalers throughout the U.S. and to explore ways to increase sales of the 11 selected tropical fruits through these outlets. Approximately 200 specialty produce wholesalers were identified by the Produce Reporter Company through its database used to publish The Blue Book (Produce Reporter Company, 1995). The same protocol was used in contacting the head buyers of the specialty produce wholesalers as was used in the survey of chain supermarket produce buyers. Each received a letter and the "Tastes of the Tropics" brochure approximately one week prior to being contacted by telephone for an interview by FAMRC research assistants. Usable data were obtained from 145 firms.

Finally, the need for improved educational materials for the trade and consumers (Objective 5) was determined through the surveys of food retailers and specialty produce wholesalers described above. Additionally, interviews of graduate students and faculty members at the University of Florida from China, India, Japan, Korea, the Phillippines, Vietnam, Colombia, Cuba, the Dominican Republic, El Salvador, Mexico and Puerto Rico were conducted to identify seasonal and holiday themes for each of these countries which would be appropriate for promoting tropical fruit. At least one representative from each of these six Asian and six Hispanic countries was selected for a personal interview. These twelve countries account for over 85 percent of the ethnic Asians and Hispanics in the targeted market regions. Information gained from these face-to-face interviews was augmented by reviewing literature which dealt with marketing to Asians and Hispanics. 


\section{FINDINGS}

The findings of this study are presented in four major sections. The first section presents the results of an extensive tropical fruit grower/shipper survey. This survey presents an assessment of the production and marketing situation affecting tropical fruits in south Florida, primarily in Dade County.

The second major section discusses ways to market tropical fruit more effectively to Asian and Hispanic consumers. It identifies major concentrations of Asian and Hispanic consumers throughout the U.S. within the context of prevailing grocery marketing regions. Also, cultural attributes of the major ethnic groups are discussed so that more effective marketing programs can be designed to reach them.

The third major section examines the marketing of the 11 selected tropical fruits through large supermarket chains located in food distribution regions where the largest concentrations of Asian and Hispanic consumers are located. It should be noted that even though the marketing regions were selected on the basis of Asian and Hispanic populations, these regions also include 149 million non-Hispanic Whites and 22.9 million Blacks. This third section summarizes market penetration and sales trends for each of the 11 fruits in major supermarket chains. Also, impediments to greater sales are explored, and currently used as well as desired promotional methods discussed.

The fourth major section presents the results of the nationwide survey of specialty produce wholesalers. This survey determined the extent of distribution by specialty wholesalers, usual sources of supply, and wholesalers' suggestions for improving Florida's tropical fruit sales.

The Summary section re-caps relevant findings and the major section entitled Conclusions and Recommendations formulates market development recommendations that can be implemented by individual growers, grower organizations and governmental agencies such as the Florida Department of Agriculture and Consumer Services.

\section{The Grower/Shipper Survey}

The findings reported here are based upon telephone interviews of 245 persons active in the tropical fruit industry in south Florida. Interviews were conducted in the first half of 1995 by FAMRC research assistants.

\section{Pre- and Post Hurricane Acreages}

Although the major emphasis of this study was on the 11 tropical fruits mentioned above, the grower survey was designed to ascertain production shifts for all commercially grown tropical fruits. This additional detail was sought because the devastation caused by Hurricane Andrew had the potential to cause major acreage shifts among fruit crops which would require changing emphasis on marketing activities. 
In total, overall acreage of tropical fruit crops as of December 31, 1994 was still 35 percent below pre-hurricane levels, with the bulk of the acreage losses represented by avocados, limes and mangoes (Table 1). The remaining tropical fruit crops grown commercially in south Florida (those with total 1992 acreages of 10 acres or more) showed an overall increase of 210 acres, or 8 percent. Carambola acreage declined from 650 to 532 acres, specialty bananas (including plantains) dropped from 400 to 300, and atemoya acreage was reduced from 83 to 41. Also, sugar apple acreage declined from 41 to 23 acres. Mamey sapote acreage was reduced slightly, from 318 to 307 acres (Table 1).

Papaya acreage nearly doubled, going from 202 to 394 acres. Lychee acreage increased by 25 percent, from 410 to 511 acres. Longan, guava, and passion fruit also showed significant gains. Longan acreage went from 206 to 294, a 43 percent increase, while guava acreage went from 147 to 197, a gain of 34 percent (Table 1). Although the 1994-95 grower survey showed an increase in passion fruit acreage from 45 to 62 acres between 1992 and the end of 1994, subsequent informal acreage estimates for 1996 revealed that acreage had declined to only 15 acres. Pummelo had a gain of 27 acres, and jackfruit 15 acres. Acreages of Barbados cherries (acerola), key lime, sapodilla, coconut, wax jambu, and persimmons showed increases of less than 10 acres each. Estimates for star apple (caimito), black sapote, Annona reticulata, canistel, akee and white sapote remained unchanged from relatively small pre-hurricane levels, ranging from one to three acres each. Additionally, very small plantings of ambarella, jaboticaba, loquat, macadamia, Monstera delicioso, Spanish lime (also known as "genip" and "mamoncillo"), tamarind and wampee are found in Dade County. However, most of these are dooryard or border plantings with limited commercial sales. Although the survey indicated some shifts were occurring toward a greater emphasis on several of the "minor" fruit crops, initial fears of very large increases appear unfounded.

The grower survey also sought to determine the prevailing marketing channels, their relative importance, and geographic distribution patterns. The survey was also designed to identify any major changes in the marketing channels that were likely to occur in the aftermath of Hurricane Andrew. Based upon the survey, no significant shifts in marketing channels are anticipated (Appendix Tables A-1 through A-3).

In general, relatively small quantities of most tropical fruits are sold by growers directly to consumers through u-pick operations, farmers' markets, or other direct sales methods. Of the 11 targeted fruits, lychees, specialty bananas, and sugar apples had the highest percentages of total production sold directly to consumers. About 7 percent of lychee production and about 5 percent of both specialty banana and sugar apple production was marketed directly to consumers. Nearly 4 percent of mango production was marketed directly, as was approximately 2 percent of guava and longan production. Less than one-half of one percent of mamey sapote, atemoya, and passion fruit production was sold directly to consumers. On-tree sales to local fruit dealers are relatively small for most of the 11 targeted fruit crops, but the most notable exception is mamey sapote. Nearly half of its production is sold in this manner, probably because of the labor-intensive picking procedure required to identify ripe fruit. Other fruits with the greatest percentages sold on-tree to dealers included sugar apple, longan, and lychee, with about 34, 13 and 8 percent sold in this manner, respectively. 
Table 1. Pre- and post-hurricane acreage and production estimates for selected tropical fruits, Dade county.

\begin{tabular}{|c|c|c|c|c|c|c|}
\hline \multirow[b]{3}{*}{ Fruit Crop ${ }^{\mathrm{a}}$} & \multicolumn{4}{|c|}{ Change } & \multirow{3}{*}{$\begin{array}{c}\text { Total } \\
\text { Production } \\
1992\end{array}$} & \multirow{3}{*}{$\begin{array}{l}\text { Anticipated } \\
\text { Production } \\
\text { at Maturity }\end{array}$} \\
\hline & \multicolumn{2}{|c|}{ Acreage estimates } & \multirow{2}{*}{$\begin{array}{l}\text { in Acreage } \\
1992-1994\end{array}$} & \multirow{2}{*}{$\begin{array}{c}\text { Acreage } \\
\text { yield/acre }^{\mathrm{b}}\end{array}$} & & \\
\hline & 1992 & 1994 & & & & \\
\hline & \multicolumn{2}{|c|}{ (-------acres-------) } & (percent) & (pounds) & \multicolumn{2}{|c|}{ (-------1,000 pounds--------) } \\
\hline Avocado & $8,987^{\mathrm{c}}$ & 6,040 & -32.8 & 13,890 & 124,829 & 83,896 \\
\hline Tahiti lime & $6,071^{\mathrm{c}}$ & 2,618 & -56.9 & 30,000 & 182,130 & 78,540 \\
\hline Mango & $2,424^{\mathrm{c}}$ & 1,550 & -36.1 & 25,000 & 60,600 & 38,750 \\
\hline Carambola & 650 & 532 & -18.2 & 39,875 & 25,919 & 21,214 \\
\hline Lychee & 410 & 511 & 24.6 & 16,763 & 6,873 & 8,566 \\
\hline Papaya & 202 & 394 & 95.0 & 35,000 & 7,070 & 13,790 \\
\hline Mamey sapote & 318 & 307 & -3.5 & 18,500 & 5,883 & 5,680 \\
\hline Banana/plantain ${ }^{\mathrm{d}}$ & 400 & 300 & -25.0 & 15,000 & 6,000 & 4,500 \\
\hline Longan & 206 & 294 & 42.7 & 15,675 & 3,229 & 4,608 \\
\hline Guava & 147 & 197 & 34.0 & 25,000 & 3,675 & 4,925 \\
\hline Barbados cherry (Acerola) & 66 & 73 & 10.6 & 16,650 & 1,099 & 1,215 \\
\hline Passion fruit & 45 & 62 & 37.8 & 21,500 & 968 & 1,333 \\
\hline Atemoya & 83 & 41 & -50.6 & 6,425 & 533 & 263 \\
\hline Pummelo & 8 & 35 & 337.5 & 25,000 & 200 & 875 \\
\hline Jackfruit & 12 & 27 & 125.0 & 32,625 & 392 & 881 \\
\hline Kumquat & 28 & 26 & -7.1 & 8,325 & 233 & 216 \\
\hline Citrus (misc.) & 26 & 24 & -7.7 & 27,000 & 702 & 648 \\
\hline Sugar apple & 41 & 23 & -43.9 & 5,400 & 221 & 124 \\
\hline Key lime & 13 & 18 & 38.5 & 12,250 & 159 & 221 \\
\hline Sapodilla & 11 & 12 & 9.1 & 10,000 & 110 & 120 \\
\hline Coconut palm & 7 & 9 & 28.6 & 10,000 & 70 & 90 \\
\hline Wax jambu & 7 & 8 & 14.3 & 19,900 & 139 & 159 \\
\hline Persimmon & 0 & 4 & n.a. & 9,063 & 0 & 36 \\
\hline Caimito (Star apple) & 3 & 3 & 0.0 & 8,000 & 24 & 24 \\
\hline Black sapote & 2 & 2 & 0.0 & 14,500 & 29 & 29 \\
\hline Annona reticulata & 2 & 2 & 0.0 & 6,695 & 13 & 13 \\
\hline Canistel & 2 & 2 & 0.0 & 20,000 & 40 & 40 \\
\hline Akee & 1 & 1 & 0.0 & 16,650 & 17 & 17 \\
\hline White sapote & 1 & 1 & 0.0 & 19,125 & 19 & 19 \\
\hline Total production & 20,173 & 13,116 & -35.0 & n.a. & n.a. & n.a. \\
\hline \multicolumn{7}{|c|}{$\begin{array}{l}\text { a'Very small plantings of ambarella, jaboticaba, loquat, macadamia, monstera delicioso, Spanish lime (also known as "genip" and } \\
\text { "mamoncillo"), tamarind and wampee are also found in Dade County. Most of these are dooryard or border plantings with limited } \\
\text { commercial sales. }\end{array}$} \\
\hline \multicolumn{7}{|c|}{$\begin{array}{l}{ }^{\mathrm{b}} \text { Average yields are for the post-hurricane period only, and were estimated from grower interviews and by University of Florida horticulturists. } \\
{ }^{\mathrm{c} A c r e a g e} \text { for this crop as of October, } 1990 \text { was estimated by the Florida Agricultural Statistics Service. This is the last official acreage } \\
\text { estimate } \\
\text { prior to Hurricane Andrew. }\end{array}$} \\
\hline
\end{tabular}


Approximately half of the mango, carambola and lychee production was reportedly picked and sold to local packer-shippers. About one-third of the papayas, specialty bananas and longans were picked and sold to packer-shippers and about one-fifth of the sugar apple production. The survey indicated that about 5 percent of mamey sapote production, 4 percent of atemoya production and less than 1 percent guava production was picked and sold to packer-shippers.

The grower survey indicated a relatively high degree of vertical integration for many of the 11 selected fruit crops. In other words, relatively large percentages of total production are grown, harvested, and self-packed and shipped to either local or distant markets. Over 96 percent of both guava and atemoya production is self-packed and shipped, as well as nearly 90 percent of all passion fruit. About two-thirds of the papaya production and slightly over half of the specialty banana and longan production is self-packed and shipped. Nearly half of the mamey sapote and mango production and about 40 percent of the carambola and sugar apple production is also self-packed and shipped (Appendix Table A-4).

Packers and shippers were asked to estimate the quantities of each type of fruit shipped to specific geographic locations. However, because of the proprietary nature of this data, several large firms were reluctant to provide this information, rendering overall distribution estimates impossible.

\section{Comments Regarding Marketing Problems}

Growers and shippers were asked what special needs, if any, they had with respect to marketing tropical fruit. Market development was the most frequently mentioned need, cited by slightly over 30 percent of all respondents (Table 2). Many expressed concerns that retailers, wholesalers and consumers are unaware of various types of tropical fruit. Many respondents felt that promotional items such as recipes, point-of-sale materials, ad copy and ad "slicks" could enhance current marketing. Some also suggested public relations efforts, general public education programs and pro-Florida advertising. Others mentioned educational programs directed at the trade, namely food retailers and produce wholesalers. Growers also requested assistance in locating and targeting domestic ethnic groups for market development. Thirty-eight of those interviewed, about 15 percent, wanted help in identifying wholesale or retail buyers of tropical fruits. Approximately the same number expressed a need for help in dealing with foreign competition (Table 2).

Sixteen growers (about six percent) complained of problems with local packers. They cited unfair business practices and poor prices. Ten survey respondents, about four percent, requested help with post-harvest handling problems, particularly storage temperature, ways to extend shelf life, and improved packing methods.

About three percent were interested in receiving better market information on prevailing prices and available quantities. A similar number said there was a need for a marketing association or cooperative, and about two percent mentioned a need for improved grades and standards. Two percent also expressed a need for some mechanism for stabilizing prices. 
Two respondents suggested that domestic supply controls would solve current marketing problems, and two also suggested that increased production was the answer. One respondent felt that a marketing order for all tropical fruit would help solve grower's marketing problems, and one other suggested that a processing plant would be helpful (Table 2).

Table 2. Growers' and shippers' expressed need s with respect to marketing tropical fruit.

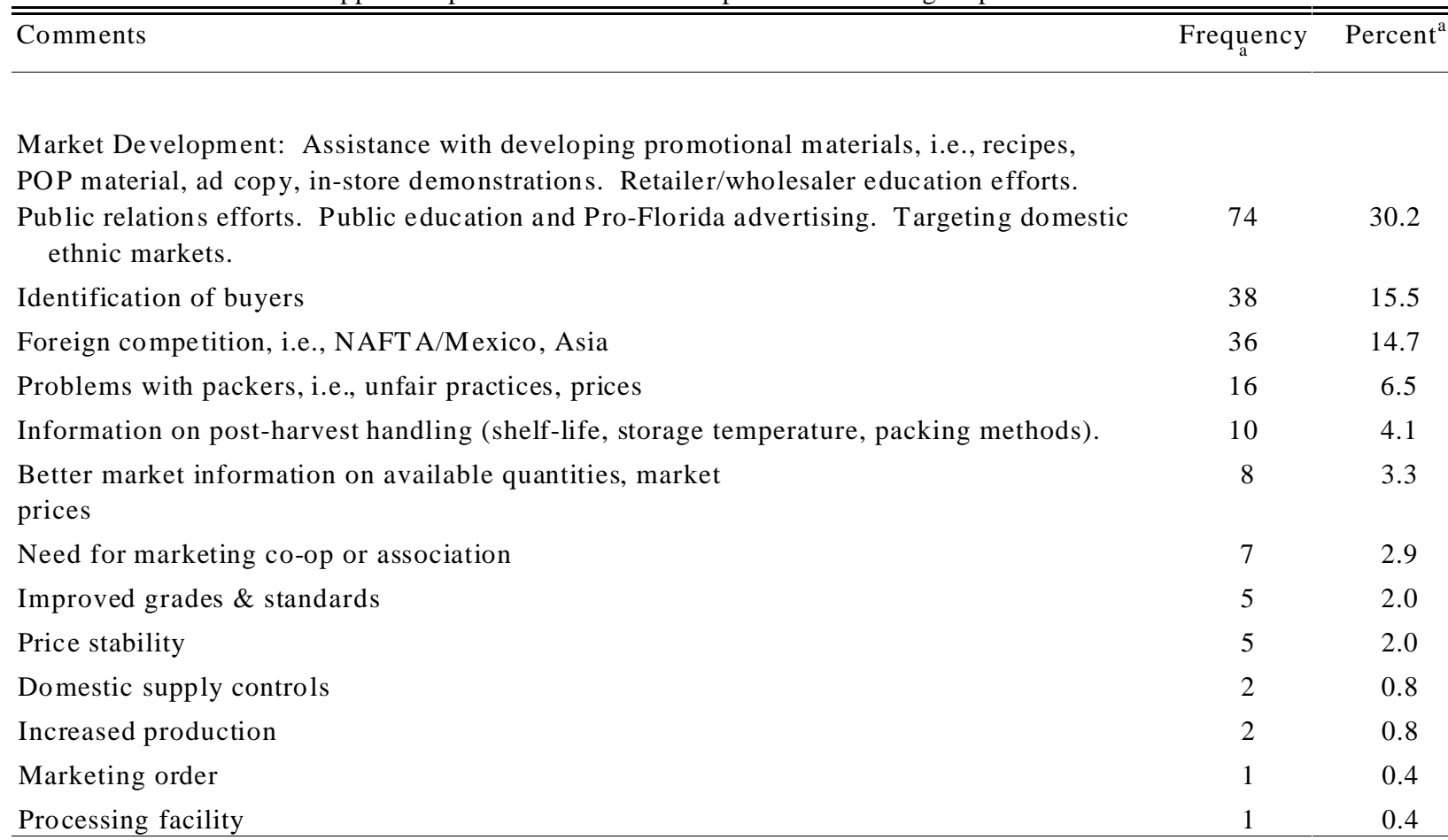

${ }^{\mathrm{a}}$ Frequencies and percentages are not summed because of multiple responses. Percentages are based upon 245 responses. 


\section{Marketing Tropical Fruits to Asian and Hispanic Consumers}

\section{Major Asian and Hispanic Markets}

Discussions with tropical fruit growers and shippers in South Florida revealed that Hispanics and Asians constitute viable markets for many tropical fruits because of their familiarity with these items and their propensity to buy them when available. Thus, the first step was to identify the geographic markets with the greatest concentrations of these ethnic groups. Accordingly, the 25 largest Hispanic and Asian markets were identified using U.S. Census data available on CD-ROM (U.S. Department of Commerce, 1990) (Table 3). The original intent was to focus on MSAs, Metropolitan Statistical Areas (MSAs) but the scope of the study was expanded to include markets which were defined as geographic regions with wellestablished food distribution patterns, as designated by Progressive Grocer's 1994 Marketing Guidebook. Detailed ethnic population statistics for Hispanics and Asians by country-of-origin were derived for each market area.

The market areas examined included a much greater geographical area than the city by which it is referenced. For example, the Boston market encompasses the city and all surrounding suburbs of Boston, as well as all or parts of Massachusetts, Rhode Island, Vermont, New Hampshire, and Maine. Thus, a total of 46 counties in five states containing an estimated population of over 8.8 million people is included in the analysis of the Boston market area.

Twenty of the top 25 Hispanic and top 25 Asian markets overlapped, resulting in a total of thirty markets throughout the U.S. that were examined. If the ethnic populations of all 30 markets are summed there are 23.7 million Hispanics, 7.0 million Asians, 149.0 million Whites (including Hispanics) and 22.9 million Blacks living in the targeted market areas. If "Asian Indian" and "Other" categories are included, the total population for all 30 market areas is about 190.1 million people. The estimated population of the U.S. in 1994 is approximately 260 million, thus the 30 markets represent roughly 73 percent of the total U.S. population (Table 4).

Table 3. Top 25 Asian and top 25 Hispanic market areas.

\begin{tabular}{|c|c|c|}
\hline Rank & Asian & Hispanic \\
\hline 1 & Los Angeles & Los Angeles \\
\hline 2 & San Francisco & New York \\
\hline 3 & New York & San Antonio \\
\hline 4 & Chicago & Albuquerque \\
\hline 5 & Baltimore/Wash. & San Francisco \\
\hline 6 & Fresno & Miami \\
\hline 7 & Seattle & Chicago \\
\hline 8 & Boston & Houston \\
\hline 9 & Houston & Fresno \\
\hline 10 & Philadelphia & Phoenix \\
\hline 11 & Dallas & Dallas \\
\hline 12 & Portland, OR & Denver \\
\hline 13 & Minneapolis & Tampa \\
\hline 14 & Detroit & Boston \\
\hline 15 & Tampa & Baltimore/Wash. \\
\hline 16 & Charlotte & Hartford \\
\hline 17 & Denver & Philadelphia \\
\hline 18 & Atlanta & Seattle \\
\hline 19 & Cincinnati & Salt Lake City \\
\hline 20 & Hartford & Portland, OR \\
\hline 21 & Miami & Detroit \\
\hline 22 & Phoenix & Kansas City \\
\hline 23 & Richmond & Milwaukee \\
\hline 24 & San Antonio & Scranton/Harrisburg \\
\hline 25 & Milwaukee & Oklahoma City \\
\hline
\end{tabular}

Source: U.S. Bureau of the Census, Population Division. 
Table 4. Resident population of the United States by race and Hispanic origin compared with the population of the thirty cities targeted for ethnic Asian and Hispanic populations.

\begin{tabular}{|c|c|c|c|c|c|}
\hline \multirow[b]{2}{*}{ Race } & \multicolumn{2}{|c|}{ U.S. population } & \multicolumn{3}{|c|}{ Population in the 30 market areas } \\
\hline & $\begin{array}{l}\text { millions } \\
\text { of } \\
\text { people }\end{array}$ & $\begin{array}{c}\text { percent of } \\
\text { U.S. } \\
\text { population }\end{array}$ & $\begin{array}{c}\text { millions } \\
\text { of } \\
\text { people }\end{array}$ & $\begin{array}{c}\text { percent of } \\
\text { population in } \\
\text { market areas }\end{array}$ & $\begin{array}{l}\text { percent of } \\
\text { racial group } \\
\text { in the U.S. }\end{array}$ \\
\hline White & 216 & $? ?$ & 149 & $? ?$ & 69.0 \\
\hline Black & 33 & $? ?$ & 23 & $? ?$ & 69.3 \\
\hline Asian and Pacific Islander & 9 & $? ?$ & 7 & $? ?$ & 77.9 \\
\hline American Indian, Eskimo, and Aleut & 2 & $? ?$ & 2 & $? ?$ & 80.5 \\
\hline Other & n.a. & n.a. & 10 & $? ?$ & \\
\hline Hispanic origin ${ }^{a}$ & 26 & $? ?$ & 24 & $? ?$ & 91.3 \\
\hline Total & 260 & 0.0 & 191 & $? ?$ & 73.4 \\
\hline
\end{tabular}

${ }^{a}$ For the most part, Hispanics are included in the "white" category above, although some are included in other categories. Thus to avoid double counting, Hispanics are not included in the total population figures.

${ }^{\mathrm{b}}$ This percentage represents the total number of people residing in the 30 markets relative to the total U.S. population.

Source: U.S. Bureau of the Census, Population Division, release PPL-41.

In addition to their general familiarity with tropical fruits, another reason for targeting marketing efforts to Hispanics and Asians is that these groups are the two fastest growing minority populations in the U.S. During the 1980-89 period, Asian population increased by about 80 percent, and the Hispanic population by 39 percent. In comparison, the Black population increased by 14 percent and Non-Hispanic Whites by only 4.4 percent (Figure 1).

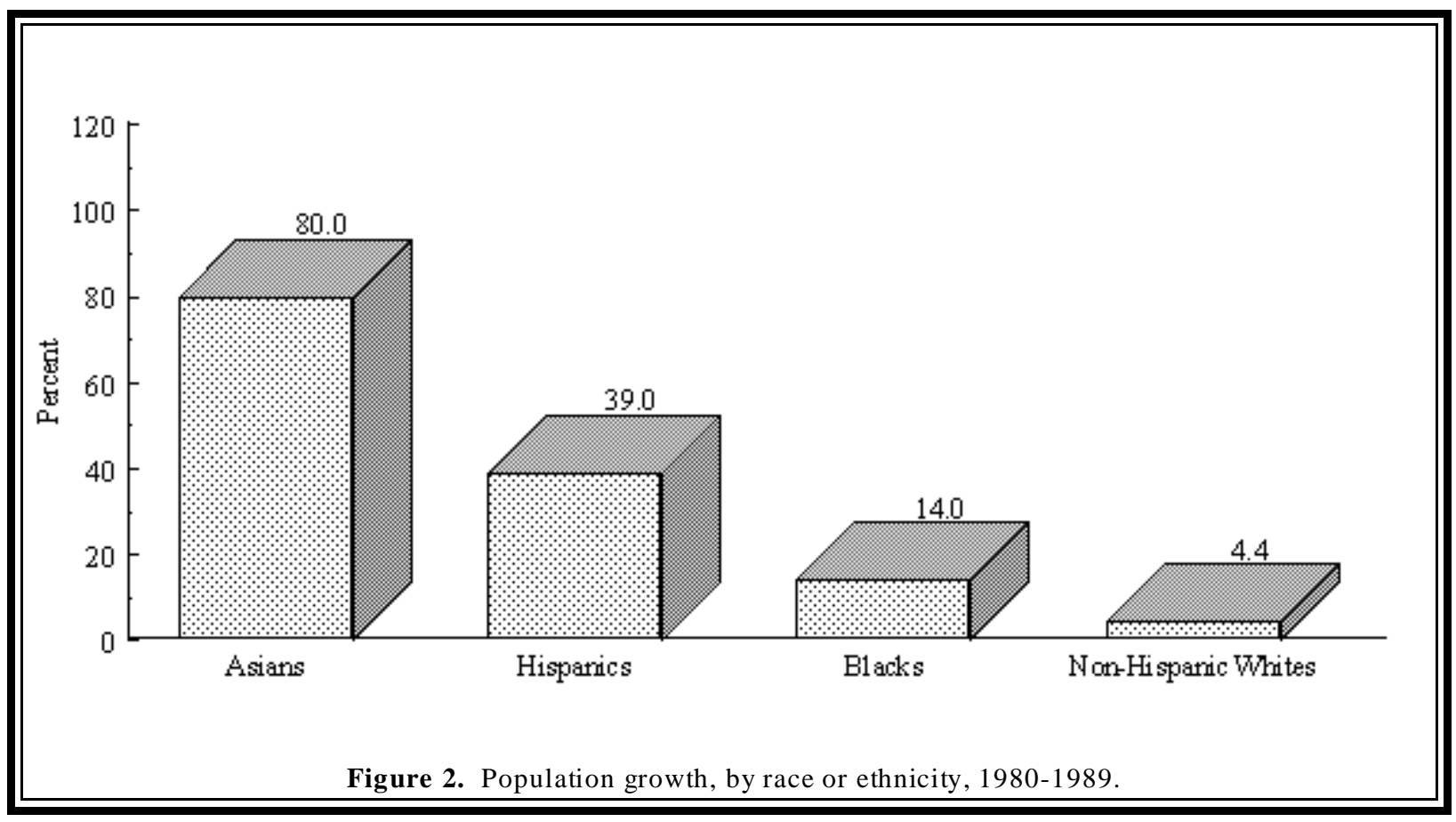


Asians are also of interest because of the relatively high median household incomes. The median household income of Asians was \$31,578 in 1988, exceeding that of all other ethnic groups (Figure 2). Median income in Asian households is higher than those in households of other ethnic groups because Asians generally have more wage-earners per household. Non-Hispanic Whites earned the next-highest median household income in 1988 with $\$ 28,661$, followed by Hispanics with $\$ 20,000$, and Blacks with $\$ 16,004$.

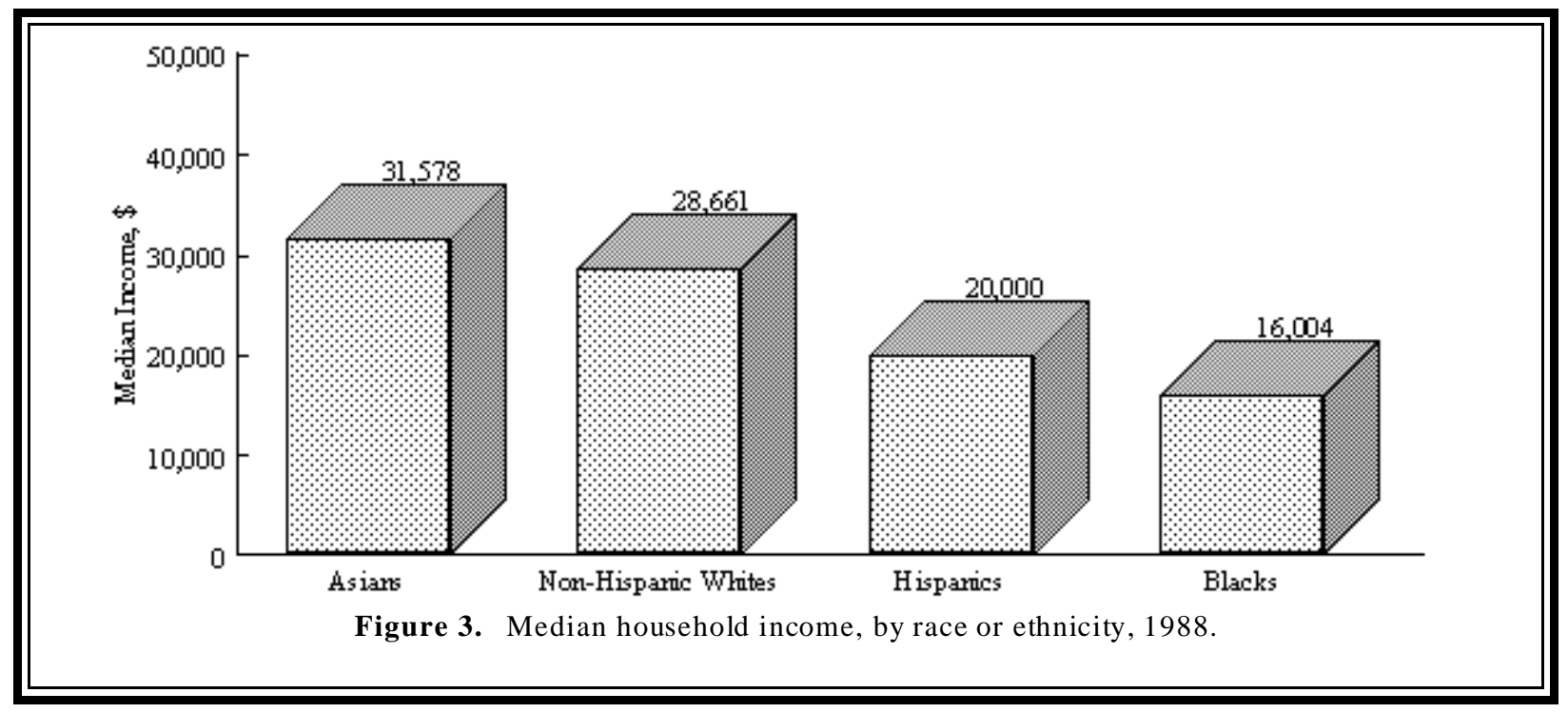

Although Asians are the fastest growing minority, Hispanics constitute one of the largest minorities in absolute numbers with about 20 million people of Hispanic origin currently living in the U.S. In 1980 there were approximately 14.5 million Hispanics in the U.S., but by the year 2000, it is likely that there will be over 25 million people of Hispanic origin living in the U.S. (Figure 3).

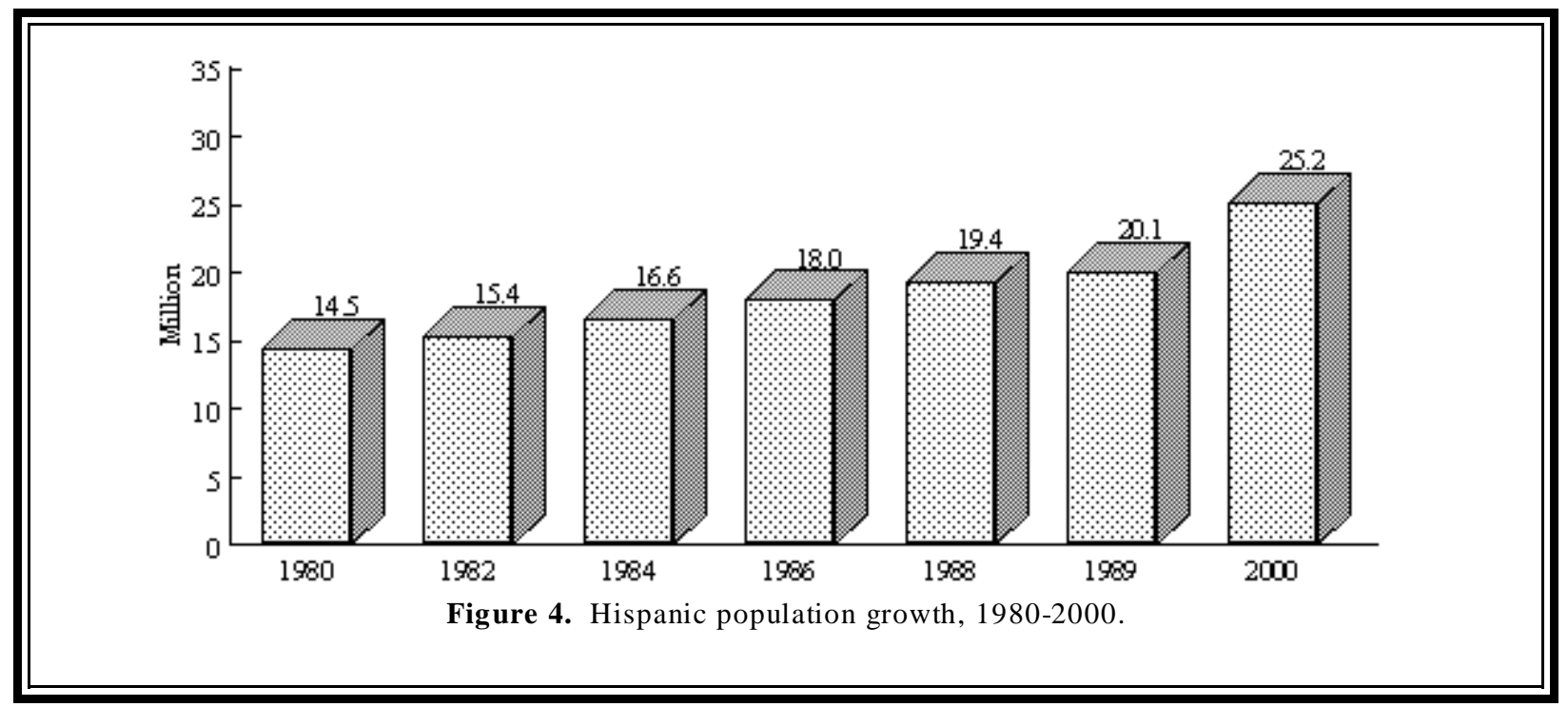




\section{Location of Top 25 Hispanic and Asian U.S. Market Regions}

Figures 4 and 5 provide a visual aid in locating the top 25 market regions with the greatest concentrations of Asians and Hispanics along with their respective ranks. Racial and general ethnic composition of each of the top 25 Asian and top 25 Hispanic market regions along with 1990-1994 population changes are found in Appendix B (Appendix Table B-1).

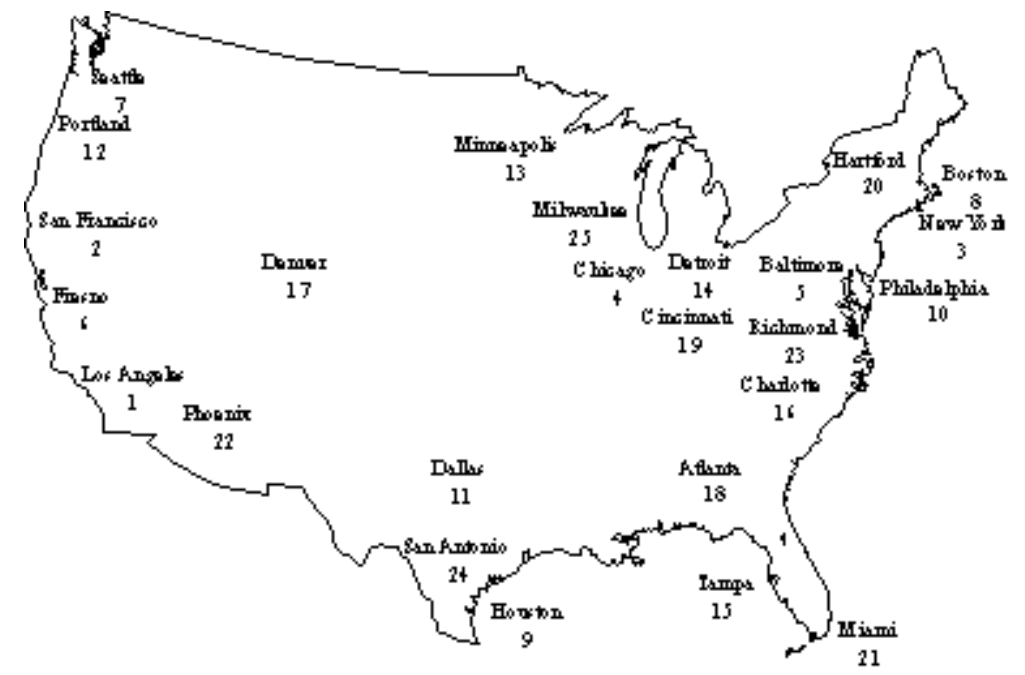

Figure 6. MSAs with the greatest concentration of Asians, ranked, 1994.

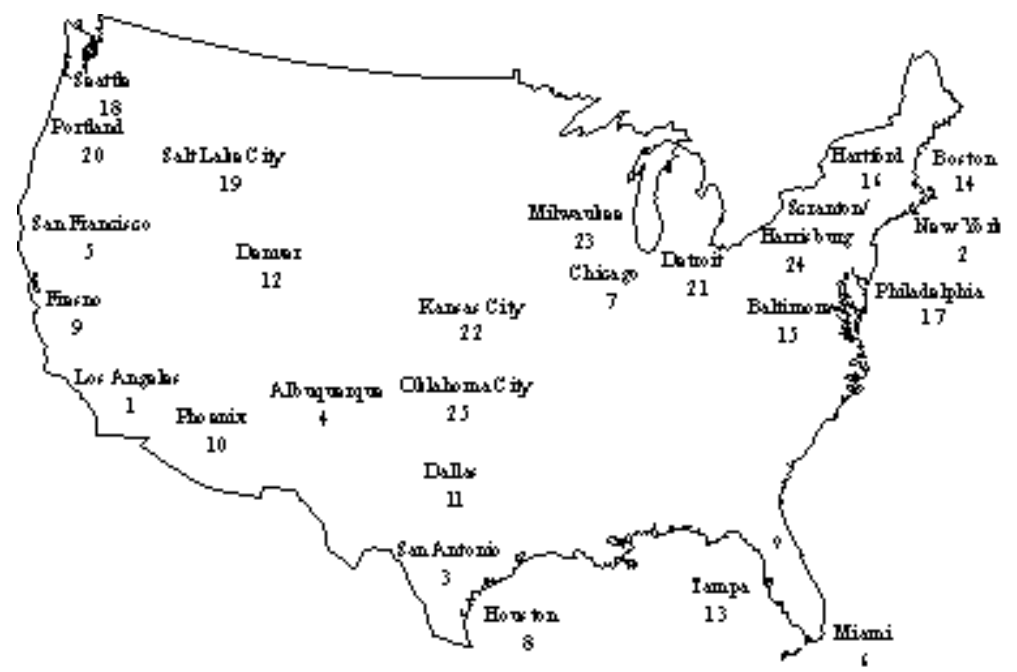

Figure 5. MSAs with the greatest concentration of Hispanics, ranked, 1994. 
Tables 5 and 6 summarize Asian and Hispanic ethnic detail for the top twenty-five market regions for each group. Asians of ethnic Chinese descent number 1.7 million, followed by Filipinos with about 1.3 million people. Asian Indians and Koreans rank third and fourth with about 0.8 million people each and Asians of Japanese and Vietnamese descent number about 0.6 million people each. Hispanics of ethnic Mexican descent are by far the most prevalent Hispanic group with 14.5 million people. Puerto Ricans rank second and Cubans third with 2.7 million and 1.2 million people, respectively. Salvadorans and Dominicans rank fourth and fifth with about 0.6 million people each.

The top six ethnic Asian groups can all be found in large numbers residing in the San Francisco, Los Angeles and New York areas. Almost 70 percent of both the Chinese and Filipino populations reside in these three areas. New York is home to about 28 percent of the Asian Indian population, followed by Los Angeles with about 11 percent. The other 23 market areas have less than 10 percent of the Asian Indian population. Roughly a third of all ethnic Koreans, Japanese and Vietnamese can be found in the Los Angeles market area. Nearly 18 percent of all Koreans live in the New York area and about 18 percent of both Japanese and Vietnamese live in the San Francisco region. (Appendix Tables B-2 through B-7).

Hispanics of Mexican descent are located predominately in the Southwest and in Southern California. The Los Angeles, San Antonio and Albuquerque regions are home to almost 60 percent of the Mexican population in the twenty-five market areas. In contrast, almost 50 percent of Puerto Ricans make their homes in the New York area. About 62 percent of Cubans are located in the Miami, Florida region. Fifty percent of Salvadorans are located in the Los Angeles area and 79 percent of Dominicans are located in the New York region. Nearly three-fourths of all Colombians are found in the New York, Miami, and Los Angeles areas. (Appendix Tables B-8 through B-13).
Table 5. Ethnic detail, aggregated for the top 25 Asian markets.

\begin{tabular}{|c|c|c|}
\hline & \multicolumn{2}{|c|}{$\begin{array}{l}1994 \text { Projected Asian } \\
\text { Population }\end{array}$} \\
\hline & (number) & (percent) \\
\hline \multicolumn{3}{|l|}{ Asian or Pacific Islander: } \\
\hline Chinese & $1,694,007$ & 24.9 \\
\hline Filipino & $1,343,697$ & 19.8 \\
\hline Asian Indian & 796,188 & 11.7 \\
\hline Korean & 785,665 & 11.6 \\
\hline Japanese & 633,294 & 9.3 \\
\hline Vietnamese & 589,405 & 8.7 \\
\hline Cambodian & 162,153 & 2.4 \\
\hline Laotian & 138,841 & 2.0 \\
\hline Hmong & 105,586 & 1.6 \\
\hline Thai & 88,475 & 1.3 \\
\hline Other Asian & 272,107 & 4.0 \\
\hline \multicolumn{3}{|l|}{ Pacific Islander: } \\
\hline \multicolumn{3}{|l|}{ Polynesian: } \\
\hline Hawaiian & 67,504 & 1.0 \\
\hline Samoan & 42,708 & 0.6 \\
\hline Tongan & 10,922 & 0.2 \\
\hline Other Polynesian & 2,698 & 0.0 \\
\hline \multicolumn{3}{|l|}{ Micronesian: } \\
\hline Guamanian & 46,319 & 0.7 \\
\hline Other Micronesian & 4,814 & 0.1 \\
\hline Melanesian & 7,565 & 0.1 \\
\hline Pacific Islander, not specified & 4,398 & 0.1 \\
\hline Total Asian market population & $6,796,346$ & 100.0 \\
\hline Total market population & $171,716,428$ & 100.0 \\
\hline $\begin{array}{l}\text { Asian population as a percent of } \\
\text { total }\end{array}$ & & 4.0 \\
\hline
\end{tabular}


Table 6. Ethnic detail, aggregated for the top 25 Hispanic markets.

\begin{tabular}{|c|c|c|c|}
\hline \multirow[b]{3}{*}{ Hispanic origin: } & \multicolumn{2}{|c|}{$\begin{array}{r}1994 \text { Projected Hispanic } \\
\text { Population }\end{array}$} & \multirow{2}{*}{$\begin{array}{l}\text { ethnic subgroups and other } \\
\text { smaller subgroups are reported } \\
\text { on a city-by-city basis in }\end{array}$} \\
\hline & (Number) & (Percent) & \\
\hline & & & Appendix Tables B-14 through \\
\hline Mexican & $14,536,792$ & 62.2 & B-63. \\
\hline Puerto Rican & $2,682,993$ & 11.5 & \\
\hline $\begin{array}{l}\text { Cuban } \\
\text { Other Hispanic: }\end{array}$ & $1,150,785$ & 4.9 & $\begin{array}{l}\text { General Cultural Attributes of } \\
\text { Asians and Hispanics }\end{array}$ \\
\hline $\begin{array}{l}\text { Dominican (Dominican } \\
\text { Republic) }\end{array}$ & 563,794 & 2.4 & A basic understanding of \\
\hline Central American: & & & Asian and Hispanic cultural \\
\hline Salvadoran & 632,445 & 2.7 & essential in devising effective \\
\hline Guatemalan & 296,668 & 1.3 & market development programs \\
\hline Nicaraguan & 221,172 & 0.9 & and materials. Simply \\
\hline Honduran & 129,506 & 0.6 & translating advertising designed \\
\hline Panamanian & 86,683 & 0.4 & for the general market into an \\
\hline Other Central American & 65,224 & 0.3 & Asian language or Spanish is \\
\hline South American: & & & insufficient because of names \\
\hline Colombian & 400,024 & 1.7 & among various dialects of the \\
\hline Ecuadorian & 206,944 & 0.9 & same basic language (i.e., \\
\hline Peruvian & 187,635 & 0.8 & Mexican Spanish vs. Cuban) or \\
\hline Other South American & 301,986 & 1.3 & because some English word \\
\hline Other Hispanic & $1,890,055$ & 8.1 & $\begin{array}{l}\text { simply do not translate directly } \\
\text { into other languages to convey }\end{array}$ \\
\hline Total Hispanic market population & $23,352,707$ & 100.0 & $\begin{array}{l}\text { the desired meaning. Campaigns } \\
\text { must take into account cultural } \\
\text { aspects of the specific ethnic }\end{array}$ \\
\hline
\end{tabular}

\section{$\underline{\text { Asians }}$}

Asian culture emphasizes tradition, responsibility, humility, duty to family, and respect for the elderly. Asians place a very high value on children and their education, and parents consider it their duty to provide an education for their children. In contrast to the American emphasis on individualism and independence, Asian children are taught to seek anonymity and not to call attention to themselves (Wong 1993, p. 70-71). Family ties are close and Asians like to spend time with family and friends. Keeping this in mind, Angi Ma Wong has compiled a list of selling words which have high appeal to the Asian consumer. This list includes words such as security, tradition, trust, future generations, children, family, and community (Wong 1993, p. 109). Thus, in keeping with Asians' appreciation for family, friends, and tradition, promotional materials should be designed to express these elements. For example, point of sale materials could convey the "traditional" 
aspects of certain tropical fruits that can be shared with family and friends to keep traditions alive. This type of appeal may be especially effective when used in conjunction with traditional events such as major holidays.

As consumers, Asians are very brand-status- and value-conscious (Tong 1991, p. 103). Quality is a major concern for Asian consumers. However, while they value luxury and quality, Asians are also frugal and will shop around for the best prices (Tong 1991, p. 103).

Although tropical fruit growers and shippers are not directly involved with retail pricing, they should be aware that many Asians associate different concepts with numbers. Eight is considered the luckiest number since it's pronunciation is similar to the pronunciation of the word meaning "to prosper," while four is the unluckiest for the Japanese, Koreans and Chinese, because it sounds like the word for "death" in all three languages, and should therefore be avoided. Five is a good number by itself, but is unlucky when placed before eight, since it sounds like "not" in Cantonese, and the combination of five-eight therefore means "not to prosper." The number three sounds similar to the word for life, and the number one sounds like the word for "guaranteed," so one before three or one before eight is considered lucky. Finally, the number nine is associated with dragons and longevity and is therefore a popular number, except for the Japanese who associate it with suffering. (Wong 1993, pp. 120-121). This type of information could be incorporated in educational and promotional packets intended for the wholesale and retail trade.

Colors also have different meanings is Asian culture. Red is a good color, as it stands for joy and happiness to the Chinese and Japanese. However, some Koreans associate this color with communism and do not like the use of it. Purple was traditionally associated with heaven and the emperor in China, while green is the color of health, growth, family life, prosperity, and harmony and therefore is a good color. Blue is a favorite of the Japanese, but the Chinese associate it with mourning. Yellow represents the earth for Chinese, and yellow chrysanthemums are used by the Koreans, Japanese, and Chinese in funeral arrangements. White is another funeral color, as is black, which is associated with death, guilt, and evil. (Wong 1993, pp. 123-124). Because color is such an important cultural consideration, particular care should be used in selecting colors for various types of point-of-sale materials, including price cards, posters, recipe cards and so forth.

Finally, it should be noted that word of mouth is extremely important in reaching the Asian market and that most Asian business stems from referrals. Since many immigrants do not use English on a daily basis until years after their arrival, Asian-language media is often the only way to reach this market. Native language newspapers are especially effective. While only 60 percent of American adults read daily newspapers, native language papers reach 95.0 percent of Chinese, 92.1 percent of Koreans, 96.5 percent of Japanese, 97.7 percent of Filipinos, and 98.4 percent of Indians (Tong 1991, p. 104).

\section{$\underline{\text { Hispanics }}$}

Hispanics are similar to Asians in the fact that they are very family oriented and often live in extended families. Hispanics also value children highly; they view children as very precious, and may overprotect them as a result. Hispanics are very religious and church oriented; most are Roman Catholic. They are a visual people who love emotional messages; Hispanics are guided by emotions 
much more than other Americans. Most foreign-born Hispanic Americans see themselves as visitors in the United States; they plan to go back home some day and want to maintain their cultural identity while living in this country (Miranda, 1996). Linking various promotional material to their home country or Hispanic heritage can be effective.

As consumers, Hispanics tend to buy brand names; they do not trust generics. Proportionally, dollars spent in the supermarket are much greater with the Hispanic consumer than the general market (American Management Association 1987, p. 19). Hispanics value quality food and are willing to pay for it. Hispanics are less likely to believe in money-back guarantees and comparisons with the competition than other Americans, but are more influenced by celebrity endorsements of products and products which are the "official" product of a sports group or event (Galceran and Berry 1995, p. 30).

The broadcast media (television and radio) is the best way to reach the Hispanic market. Hispanics prefer to spend their free time in group activities, and watching television or listening to the radio are much more group oriented than reading (American Management Association 1987, $\mathrm{p}$. 20). Hispanics watch 30 percent more television and listen to 20 percent more radio than other Americans, and 64 percent of Hispanics say their favorite leisure activity is "watching Spanish tv" (Miranda 1996, p. 24).

\section{$\underline{\text { Asian and Hispanic holidays }}$}

As in most cultures, Asian and Hispanic ethnic groups celebrate holidays and festivals at various times throughout the year, and food often plays an important role on these occasions. Also, many of these events coincide with the availability of tropical fruits produced in south Florida, providing opportunities for promotional tie-ins which could greatly enhance sales.

Holidays celebrated by the six largest ethnic sub-groups of Asians and Hispanics (Chinese, Filipino, Asian Indian, Korean, Japanese, Vietnamese, Mexican, Puerto Rican, Cuban, Salvadoran, Dominican and Columbian) were identified through secondary sources and confirmed through faceto-face interviews with graduate students and faculty members at the University of Florida. Each respondent was a native of one of these countries or had extensive professional experience in a respective country. Respondents were asked to identify holidays that were likely to be celebrated by numbers of the various ethnic groups after they had become established in the U.S. Respondents were then asked to rate the overall importance of each holiday using a three point semantic scale where 1 = "very important", 2 = "moderately important" and 3 = "minor importance". Additionally, respondents were asked to rate the importance of food in celebrating the holiday with a similar three point scale where $\mathrm{A}=$ "very significant", $\mathrm{B}=$ "moderately significant", and $\mathrm{C}=$ "not significant". Thus, a rating of $1 \mathrm{~A}$ would indicate a very important holiday where food plays a very significant role in its celebration. Table 7 summarizes all such 1A ratings by months of availability for selected tropical fruits and by Asian ethnic subgroups, and Table 8 does the same for major Hispanic subgroups. Specific holidays, their relative importance, and dates celebrated are organized by month and country and reported in Appendix Tables B-64 and B-65. 
Table 7. Summary of major Asian holidays where food is very important, by month and tropical fruit availability.

\begin{tabular}{|c|c|c|c|c|c|c|c|c|c|c|c|c|}
\hline Fruits & January & February & March & April & May & June & July & August & September & October & November & December \\
\hline Carambola & $\begin{array}{c}\text { Chinese } \\
\text { Japanese } \\
\text { Filipino } \\
\text { Korean }\end{array}$ & $\begin{array}{c}\text { Filipino } \\
\text { Vietnamese }\end{array}$ & $\begin{array}{l}\text { Indian } \\
\text { Filipino }\end{array}$ & & & & & $\begin{array}{l}\text { Chinese } \\
\text { Korean }\end{array}$ & Indian & Indian & & $\begin{array}{c}\text { Chinese } \\
\text { Japanese } \\
\text { Filipino }\end{array}$ \\
\hline Banana & $\begin{array}{c}\text { Chinese } \\
\text { Japanese } \\
\text { Filipino } \\
\text { Korean }\end{array}$ & $\begin{array}{c}\text { Filipino } \\
\text { Vietnamese }\end{array}$ & $\begin{array}{l}\text { Indian } \\
\text { Filipino }\end{array}$ & Japanese & & & Indian & $\begin{array}{l}\text { Chinese } \\
\text { Korean }\end{array}$ & Indian & Indian & & $\begin{array}{c}\text { Chinese } \\
\text { Japanese } \\
\text { Filipino }\end{array}$ \\
\hline Mamey & $\begin{array}{c}\text { Chinese } \\
\text { Japanese } \\
\text { Filipino } \\
\text { Korean }\end{array}$ & $\begin{array}{c}\text { Filipino } \\
\text { Vietnamese }\end{array}$ & $\begin{array}{l}\text { Indian } \\
\text { Filipino }\end{array}$ & Japanese & & & Indian & $\begin{array}{l}\text { Chinese } \\
\text { Korean }\end{array}$ & Indian & & & \\
\hline Guava & $\begin{array}{l}\text { Chinese } \\
\text { Japanese } \\
\text { Filipino } \\
\text { Korean }\end{array}$ & $\begin{array}{c}\text { Filipino } \\
\text { Vietnamese }\end{array}$ & & & & & Indian & $\begin{array}{l}\text { Chinese } \\
\text { Korean }\end{array}$ & Indian & Indian & & \\
\hline Papaya & $\begin{array}{c}\text { Chinese } \\
\text { Japanese } \\
\text { Filipino } \\
\text { Korean }\end{array}$ & $\begin{array}{c}\text { Filipino } \\
\text { Vietnamese }\end{array}$ & $\begin{array}{l}\text { Indian } \\
\text { Filipino }\end{array}$ & Japanese & & & Indian & $\begin{array}{l}\text { Chinese } \\
\text { Korean }\end{array}$ & Indian & Indian & & $\begin{array}{l}\text { Chinese } \\
\text { Japanese } \\
\text { Filipino }\end{array}$ \\
\hline $\begin{array}{l}\text { Passion } \\
\text { Fruit }\end{array}$ & $\begin{array}{l}\text { Chinese } \\
\text { Japanese } \\
\text { Filipino } \\
\text { Korean }\end{array}$ & $\begin{array}{c}\text { Filipino } \\
\text { Vietnamese }\end{array}$ & $\begin{array}{l}\text { Indian } \\
\text { Filipino }\end{array}$ & & & & Indian & $\begin{array}{l}\text { Chinese } \\
\text { Korean }\end{array}$ & Indian & Indian & & $\begin{array}{c}\text { Chinese } \\
\text { Japanese } \\
\text { Filipino }\end{array}$ \\
\hline Lychee & & & & & $\begin{array}{l}\text { Chines } \\
\text { e }\end{array}$ & & & & & & & \\
\hline Mango & & & & & & & Indian & $\begin{array}{l}\text { Chinese } \\
\text { Korean }\end{array}$ & Indian & & & \\
\hline Longan & & & & & & & Indian & $\begin{array}{c}\text { Chinese } \\
\text { Korean }\end{array}$ & & & & \\
\hline Atemoya & & & & & & & & $\begin{array}{l}\text { Chinese } \\
\text { Korean }\end{array}$ & Indian & Indian & & \\
\hline $\begin{array}{l}\text { Sugar } \\
\text { Apple }\end{array}$ & & & & & & & & $\begin{array}{c}\text { Chinese } \\
\text { Korean }\end{array}$ & Indian & Indian & & \\
\hline
\end{tabular}


Table 8. Summary of major Hispanic holidays where food is very important by month and tropical fruit availability.

\begin{tabular}{|c|c|c|c|c|c|c|c|c|c|c|c|c|}
\hline Fruits & January & February & March & April & May & June & July & August & September & October & November & December \\
\hline Ca rambola & Columbians & $\begin{array}{l}\text { Puerto } \\
\text { Ricans }\end{array}$ & $\begin{array}{l}\text { Columbians } \\
\text { Dominicans } \\
\text { Salvadorans } \\
\text { Puerto Ricans }\end{array}$ & & & & & & Mexicans & & $\begin{array}{c}\text { Cubans } \\
\text { Salvadorans } \\
\text { Mexicans }\end{array}$ & $\begin{array}{l}\text { Columbians } \\
\text { Cubans } \\
\text { Salvadorans } \\
\text { Mexicans } \\
\text { Puerto.Ricans. }\end{array}$ \\
\hline Banana & Columbians & $\begin{array}{l}\text { Puerto } \\
\text { Ricans }\end{array}$ & $\begin{array}{l}\text { Columbians } \\
\text { Dominicans } \\
\text { Salvadorans } \\
\text { Puerto Ricans }\end{array}$ & $\begin{array}{l}\text { Puerto } \\
\text { Ricans }\end{array}$ & $\begin{array}{l}\text { Puerto } \\
\text { Ricans }\end{array}$ & & & & Mexicans & 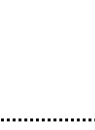 & $\begin{array}{c}\text { Cubans } \\
\text { Salvadorans } \\
\text { Mexicans }\end{array}$ & Columbians \\
\hline Mamey & Columbians & $\begin{array}{l}\text { Puerto } \\
\text { Ricans }\end{array}$ & $\begin{array}{c}\text { Columbians } \\
\text { Dominicans } \\
\text { Salvadorans } \\
\text { Puerto Ricans }\end{array}$ & $\begin{array}{l}\text { Puerto } \\
\text { Ricans }\end{array}$ & & & & & Mexicans & & & \\
\hline Guava & Columbians & $\begin{array}{l}\text { Puerto } \\
\text { Ricans... }\end{array}$ & & & $\begin{array}{l}\text { Puerto } \\
\text { Ricans. }\end{array}$ & & & & Mexicans & & & \\
\hline Papaya & Columbians & $\begin{array}{l}\text { Puerto } \\
\text { Ricans }\end{array}$ & $\begin{array}{c}\text { Columbians } \\
\text { Dominicans } \\
\text { Salvadorans } \\
\text { Puerto.Ricans......................... }\end{array}$ & $\begin{array}{l}\text { Puerto } \\
\text { Ricans }\end{array}$ & $\begin{array}{l}\text { Puerto } \\
\text { Ricans }\end{array}$ & & & & Mexicans & & $\begin{array}{c}\text { Cubans } \\
\text { Salvadorans } \\
\text { Mexicans }\end{array}$ & Columbians \\
\hline $\begin{array}{l}\text { Passion } \\
\text { Fruit }\end{array}$ & Columbians & $\begin{array}{l}\text { Puerto } \\
\text { Ricans }\end{array}$ & $\begin{array}{c}\text { Columbians } \\
\text { Dominicans } \\
\text { Salvadorans } \\
\text { Puerto Ricans }\end{array}$ & & & & & & Mexicans & & $\begin{array}{c}\text { Cubans } \\
\text { Salvadorans } \\
\text { Mexicans }\end{array}$ & Columbians \\
\hline Lychee & & & & & $\begin{array}{l}\text { Puerto } \\
\text { Ricans }\end{array}$ & & & & & & & \\
\hline Mango & & & & & & & & & Mexicans & & & \\
\hline Longan & & & & & & & & & Mexicans & & & \\
\hline Atemoya & & & & & & & & & Mexicans & & & \\
\hline $\begin{array}{l}\text { Sugar } \\
\text { Apple }\end{array}$ & & & & & & & & & Mexicans & & & \\
\hline
\end{tabular}




\section{The Chain Supermarket Survey}

The original objective was to identify the Metropolitan Statistical Areas (MSAs) where the top 25 concentrations of Asian and Hispanic populations were located and then survey the major supermarket chains operating in these MSAs to determine ways to increase tropical fruit sales through these outlets. However, the scope of the study was expanded to include not only the counties which constitute the MSAs as defined by the Bureau of the Census, but to include all counties within the prevailing grocery distribution regions as defined by Progressive Grocer. Head produce buyers of the three largest chains (in terms of sales) in each market were then contacted by letter to legitimize the survey and by telephone for interviews. Usable data were obtained from 75 firms which represented a total of 15,155 stores.

Initial contacts within each firm were made with the head produce buyer, the intent being to interview the most experienced, knowledgeable person with respect to tropical fruit. In some very large firms, however, produce buyers tend to specialize in selected commodities. In these cases, buyers, responsible for tropical fruits were interviewed. The chain supermarket produce buyer survey covered several topics, including availability of each of the 11 selected fruits, general sales performance, and promotional methods that had been used for tropical fruits. They were also queried as to preferred types and sizes of point-of-sale material, and were also asked to recommend ways to increase sales of Florida-grown tropical fruit.

\section{Availability of Selected Tropical Fruits in Major Supermarkets}

Produce buyers were asked how many of their stores carried each of the 11 selected fruits at some time during the course of a year, i.e., during the typical "season" for seasonal items. They were also asked to indicate how many of their stores sold the targeted tropical fruits on an infrequent or special order basis.

Mangos, papayas and carambolas were found to be very popular and widely available. Mangos and papayas were carried on a regular basis by all of the cooperating firms in all of their stores (Table 9). Carambolas were regularly carried by 71 of the 75 chains, representing 97 percent of all stores. Passion fruit was available on a regular basis in 54 chains representing 70 percent of all stores, and guavas regularly handled by 49 firms representing about two-thirds of all stores.

Specialty bananas were sold by 43 of the 75 firms representing about 60 percent of all stores. Lychees were available on a regular seasonal basis by only 29 of the 75 firms; these firms accounted for just under half of all stores. However, produce buyers from 20 additional firms indicated that lychees were occasionally handled by some of their stores on a special order basis; thus, lychees had the potential to be available in about 70 percent of all stores.

Availability of the remaining four tropical fruits, namely atemoyas, mamey sapotes, longans, and sugar apples was found to be comparatively limited. Atemoyas and mamey sapotes were both available seasonally in about one-fourth of all firms representing approximately 30 percent of all stores. Longans were available in 12 chains with 17 percent of the stores, and sugar apples were available in only 7 chains accounting for 7 percent of all stores. Availability of these last four tropical fruits on a special order basis was also quite limited (Table 9). 
Table 9. Availability of selected tropical fruits.

\begin{tabular}{|c|c|c|c|c|c|c|c|c|c|}
\hline \multirow[t]{2}{*}{ Fruit } & \multicolumn{3}{|c|}{ Availability on a regular basis } & \multicolumn{3}{|c|}{$\begin{array}{l}\text { Availability by special } \\
\text { order only }\end{array}$} & \multicolumn{3}{|c|}{ Total availability } \\
\hline & Firms & Stores & $\%$ Stores & Firms & Stores & $\%$ Stores & Firms & Stores & $\%$ Stores \\
\hline Mango & 75 & 15,155 & 100 & 0 & 0 & 0 & 75 & 15,155 & 100 \\
\hline Papaya & 75 & 15,155 & 100 & 0 & 0 & 0 & 75 & 15,155 & 100 \\
\hline Carambola & 71 & 14,723 & 97 & 1 & 45 & 0 & 72 & 14,768 & 97 \\
\hline Passion Fruit & 54 & 10,627 & 70 & 9 & 2,906 & 19 & 63 & 13,533 & 89 \\
\hline Guava & 49 & 9,938 & 66 & 10 & 2,716 & 18 & 59 & 12,654 & 84 \\
\hline Banana & 43 & 9,263 & 61 & 7 & 2,128 & 14 & 50 & 11,391 & 75 \\
\hline Lychee & 29 & 7,239 & 48 & 20 & 3,186 & 21 & 49 & 10,425 & 69 \\
\hline Atemoya & 22 & 4,886 & 32 & 10 & 2,465 & 16 & 32 & 7,351 & 48 \\
\hline Mamey Sapote & 18 & 4,286 & 28 & 9 & 1,685 & 11 & 27 & 5,971 & 39 \\
\hline Longan & 12 & 2,592 & 17 & 8 & 1,997 & 13 & 20 & 4,589 & 30 \\
\hline Sugar Apple & 7 & 1,115 & 7 & 4 & 760 & 5 & 11 & 1,875 & 12 \\
\hline
\end{tabular}

Source: Mazak and Degner, 1994.

\section{Sales Performance}

Sales performance of the 11 selected fruits was rated as "excellent", "fair" or "poor" by produce buyers with first-hand knowledge of sales within their firms. Mangos, papayas, and carambolas received the most favorable sales performance ratings, with approximately 80 to 90 percent of the produce buyers indicating that sales were excellent or fair. Mangos received the highest ratings, with 87 percent of all buyers reporting excellent sales, followed by carambolas with about 47 percent indicating excellent sales (Table 10). The remaining eight fruits received substantially lower sales performance ratings. Of these eight, lychees received "poor" sales ratings from about 60 percent of the chainstore buyers. About two-thirds of the buyers gave "poor" sales performance ratings to atemoyas, specialty bananas and mamey sapotes. The worst overall sales performance ratings were given to passion fruit, sugar apples, guavas and longans, with "poor" ratings of about 79, 79, 81, and 88 percent of the buyers, respectively (Table 10).
Table 10. Sales performance of selected tropical fruit.

\begin{tabular}{lcrrr}
\hline \hline Fruit & $\begin{array}{c}\text { Number of } \\
\text { Chains } \\
\text { Reporting }\end{array}$ & Excellent & Fair & Poor \\
\hline & & & & \\
Atemoya & 32 & 5.9 & 28.2 & 65.9 \\
Banana & 50 & 12.9 & 19.5 & 67.6 \\
Carambola & 72 & 47.3 & 35.6 & 17.1 \\
Guava & 59 & 4.0 & 15.1 & 80.9 \\
Lychee & 49 & 20.5 & 20.5 & 59.0 \\
Longan & 20 & 12.3 & 0.0 & 87.7 \\
Mamey & 27 & 29.6 & 3.5 & 66.8 \\
Sapote & & 87.3 & 4.5 & 8.2 \\
Mango & 75 & 30.7 & 53.5 & 15.8 \\
Papaya & 75 & 0.0 & 21.3 & 78.7 \\
Passion Fruit & 63 & 21.1 & 0.0 & 78.9 \\
Sugar Apple & 11 & & & \\
\hline
\end{tabular}

Source: Mazak and Degner, 1994. 


\section{Impediments to Better Sales Performance}

During the course of discussions about sales performance of each type of fruit, buyers were asked an open-ended question about the major obstacles to improved sales. Four basic problem areas were identified by the buyers: (1) lack of consumer knowledge and awareness, (2) relatively high prices for tropical fruit, (3) limited supplies and (4) quality considerations.

The percentage of chainstore buyers that mentioned lack of consumer knowledge as a serious sales impediment ranged from about 40 to 70 percent, depending on the specific fruit in question. Despite being one of the most widely available fruits and having the best sales ratings, 41 percent of the managers representing the same percentage of stores said that mangos' sales performance was currently limited by consumers' unfamiliarity. Nearly 70 percent indicated that guava sales were hampered by lack of consumer knowledge, and about 60 percent expressed concerns that sales of passion fruit and sugar apples were constrained by this factor as well. Consumers' lack of knowledge was cited as a sales barrier by about half of the buyers for the other fruits under consideration as well.

Significant numbers of buyers mentioned high prices as a major reason for limited sales. Papaya, passion fruit and carambola were among those fruits viewed as too expensive by approximately 20 percent of the chainstore buyers (Table 11). Price was mentioned as a significant detriment to greater sales of the remaining seven fruits by about 10 to 15 percent of the buyers.

Supply considerations such as limited or inconsistent supplies and short production seasons were also mentioned as limiting tropical fruit sales. However, for most fruits the percentages of buyers mentioning this factor were quite low, usually ranging from 3 to 5 percent. The most supply-related complaints were directed at carambolas, with about 20 percent of the buyers indicating that their sales were constrained by the shortness of the season. This large percentage is probably due to the relatively high degree of familiarity with carambolas, coupled with many buyers' expectations of year-round supplies for many popular produce items. Much smaller numbers, about 5 percent of the buyers, expressed some frustration over limited or inconsistent supplies. A few buyers, about 5 to 7 percent, complained
Table 11. Chain supermarket buyers perceptions that tropical fruit is too expensive.

\begin{tabular}{|c|c|c|c|c|}
\hline \multirow{3}{*}{ Fruit } & \multicolumn{4}{|c|}{ Perception that fruit is too expensive } \\
\hline & \multicolumn{2}{|c|}{ Firms } & \multicolumn{2}{|c|}{ Stores } \\
\hline & (Number) & $(\text { Percent })^{\mathrm{a}}$ & (Number) & $(\text { Percent })^{\mathrm{a}}$ \\
\hline Atemoya & 10 & 15.4 & 2,403 & 17.5 \\
\hline $\begin{array}{l}\text { Specialty } \\
\text { bananas }\end{array}$ & 8 & 10.7 & 2,246 & 14.8 \\
\hline Carambola & 14 & 18.7 & 3,219 & 21.2 \\
\hline Guava & 10 & 13.5 & 2,030 & 13.5 \\
\hline Lychee & 12 & 16.9 & 2,773 & 19.3 \\
\hline Longan & 5 & 9.1 & 1,223 & 10.7 \\
\hline Mamey sapote & 6 & 10.0 & 1,873 & 14.5 \\
\hline Mango & 8 & 10.7 & 1,507 & 9.9 \\
\hline Papaya & 16 & 21.3 & 3,230 & 21.3 \\
\hline Passion fruit & 14 & 18.7 & 2,308 & 15.2 \\
\hline Sugar apples & 7 & 13.7 & 1,813 & 18.7 \\
\hline
\end{tabular}

${ }^{2}$ Percentages are based on the following numbers: Atemoya, 65 firms, 13,707 stores; guava, 74 firms, 15,005 stores; lychee, 71 firms, 14,360 stores; longan, 55 firms, 11,411 stores; mamey sapote, 60 firms, 12,924 stores; sugar apple, 51 firms, 9,701 stores. 
about the short seasonal availability of lychees, longans, and Florida mangos. For most of the 11 tropical fruits, complaints about product quality were minimal. However, 8 of the 75 buyers (11 percent) were critical of the arrival condition of specialty bananas. Most complained of bruising, but several also mentioned inconsistent ripening, i.e., primarily unripe fruit.

Mango quality also received a lot of discussion, but most of the comments were directed at varietal differences. About one-fourth of the buyers specifically mentioned a preference for the 'Tommy Atkins' variety, and an additional one-fifth were adamant about their preference for blush varieties, with several buyers stating unequivocably that they did not want green varieties. The general consensus is that the attractiveness of blush varieties has greater consumer (sales) appeal. Virtually all buyers' comments regarding quality had to do with appearance. Although mainstream American consumers and many Hispanics may prefer blush varieties, Asians, especially immigrants from Southeast Asia and India, may be more familiar with yellow or greenish yellow skinned varieties which have little or no blush. Varieties such as 'Saigon' and 'Nam Doc Mai' may appeal to these ethnic consumers because of their excellent eating qualities. Some Asians also enjoy pickled mangos, and some like to eat low-acid mangos green. The 'Brooks Late', and 'Keitt' could be promoted to Asians for pickling when green, and the 'Nam Doc Mai' as a low acid type fruit that is to be eaten green (Campbell, 1992).

Buyers made very few negative comments about carambola; several buyers representing relatively large chains were not pleased with tart varieties, suggesting that only the sweet type be shipped.

Several buyers emphasized that quality was of paramount importance for lychees and longans. They felt that Asian buyers were particularly quality conscious, an opinion confirmed by survey research (Wong, 1993). As for papaya, several buyers noted that the quality of fruit from Florida had improved, but several others mentioned the need for further improvement. Appearance and ripeness were the attributes mentioned most frequently. Several buyers expressed a strong preference for Hawaiian varieties over Florida's.

For the remaining fruits, very few quality problems were noted. The one recurring suggestion was to improve the fruits' appearance, i.e., by reducing or eliminating blemishes and bruises.

\section{Promotional Methods}

All buyers were asked what methods had been used for promoting tropical fruits in their stores. They were also asked to rate the effectiveness of each method used, using a 10 point scale where 10 represented "excellent" and 1 represented "very poor".

Fourteen of the 75 cooperating firms reportedly used no promotional activities of any type for tropical fruit, other than basic product identification signs in their stores. These 14 firms represented nearly 20 percent of the cooperating firms, and accounted for slightly over 21 percent of all stores. These firms also reported minimal sales performance, with all reporting fair or poor sales for all 11 of the tropical fruits studied. 
Advertising in newspaper circulars/flyers was the most commonly used promotional method, used by 43 of the 75 firms. These 43 firms represent nearly 60 percent of all stores, and 73.0 percent of the stores that engaged in some form of promotion. The average effectiveness rating was 7.4 (Table 12).

Table 12. Promotional activities reported used for tropical fruit by chainstores, 1994-95.

\begin{tabular}{|c|c|c|c|c|c|c|}
\hline $\begin{array}{l}\text { Promotional } \\
\text { Activities }\end{array}$ & $\begin{array}{l}\text { Number of } \\
\text { Firms }\end{array}$ & $\begin{array}{l}\text { Percent of } \\
\text { Firms }^{\mathrm{a}}\end{array}$ & Stores & $\begin{array}{c}\text { Percent of All } \\
\text { Stores }^{\mathrm{b}}\end{array}$ & $\begin{array}{c}\text { Percent of Stores } \\
\text { Promoting Tropical } \\
\text { Fruit }^{\mathrm{c}}\end{array}$ & $\begin{array}{l}\text { Average } \\
\text { Rating }^{\mathrm{d}}\end{array}$ \\
\hline Newspaper flyers & 43 & 57.3 & 8,715 & 57.5 & 73.0 & 7.4 \\
\hline $\begin{array}{l}\text { In-store } \\
\text { demonstrations }\end{array}$ & 35 & 46.7 & 6,121 & 40.4 & 51.3 & 8.4 \\
\hline Price specials & 13 & 17.3 & 2,709 & 17.9 & 22.7 & 8.1 \\
\hline Special displays & 9 & 12.0 & 1,386 & 9.1 & 11.6 & 6.7 \\
\hline Recipes & 5 & 6.7 & 1,208 & 8.0 & 10.1 & 6.5 \\
\hline $\begin{array}{l}\text { Tropical fruit } \\
\text { promotions }\end{array}$ & 6 & 8.0 & 1,196 & 7.9 & 10.0 & 7.0 \\
\hline In-store signs & 3 & 4.0 & 607 & 4.0 & 5.1 & 5.8 \\
\hline Mixed-pack sales & 2 & 2.7 & 293 & 1.9 & 2.5 & 7.5 \\
\hline Coupons & 1 & 1.3 & 160 & 1.1 & 1.3 & 9.0 \\
\hline In-store videos & 1 & 1.3 & 101 & 0.7 & 0.8 & 6.0 \\
\hline None reported & 14 & 18.7 & 3,222 & 21.3 & n.a. & n.a. \\
\hline
\end{tabular}

In-store demonstrations were the second most frequently utilized promotional method, reported by 35 of the 75 firms. These 35 firms represented slightly over 40 percent of all stores, and over 50 percent of the stores promoting tropical fruit. In-store demonstrations received one of the highest effectiveness rating of all, 8.4 on the 10 point scale (Table 12).

Price specials or price reductions were also one of the most commonly used promotional methods reported by 17 percent of all firms and nearly one-fourth of the stores that used some type of promotion. Price specials were also rated quite high with respect to effectiveness, receiving an 8.1 rating, second only to in-store demonstrations (Table 12).

Special individual fruit displays, recipes, and multiple fruit "tropical fruit" displays were used by about 12, 7 and 8 percent of the firms, respectively. These methods were used in 8 to 9 percent of all stores, and received relatively low effectiveness ratings, ranging from 6 to 7 on the 10 point effectiveness scale (Table 12).

In-store signs were used to promote tropical fruit sales by only three firms, and effectiveness ratings were quite low, averaging only 5.8. Mixed pack (sample packs) were used by several firms. 
Representatives of these firms felt that relatively small sample packs stimulated customers' curiosity and encouraged them to try the exotic, unknown items. Coupons and in-store videos had each been tried by only one firm to promote tropical fruit. Because of the small numbers of firms using in-store signs and videos, sample packs, and coupons, effectiveness ratings for these promotional methods should be interpreted with caution.

After produce buyers had discussed the various types of promotional methods that had been tried in their stores, they were read a list of commonly used promotional methods and materials and asked to indicate whether or not they would recommend using them to promote tropical fruit. This aided recall approach was used to assure a broad-based evaluation of the kinds of items found in many promotional kits used by commodity groups in generic promotional programs.

Price cards from outside sources were mentioned as an acceptable item by just over 60 percent of the 72 produce buyers; however, these firms accounted for only 41 percent of the stores (Table 13). This disproportionately small number of stores relative to the number of firms is due to the greater tendency of small chains to use point of sale materials from outside suppliers whereas many large firms prefer to use in-house POS materials to achieve a cleaner, more uniform store appearance.

Thirty-two of the 45 buyers willing to use price cards from outside sources indicated a preferred size. The 32 respondents expressed preferences for a total of 15 specific dimension ranging from $3 "$ x 5" to $11 "$ x $14 "$. The most frequently mentioned size preference was for 7" x 11", cited by nearly a third of all respondents. The second most frequently preferred size was $8.5^{\prime \prime} \mathrm{x} 11 "$, mentioned by 13 percent of those expressing a preference. Price cards measuring 5" x 7" and 3" x 5" were mentioned by equal numbers of buyers, roughly 10 percent of those responding (Table 14). Dimensions of 4" x 6" and 8" x 11" were also mentioned by more than one firm. However, nine additional sizes such as 4" x 4", 4" x 5", etc. were mentioned by nine different buyers (Table 14). Despite the tremendous diversity in preferred sizes, there was consistency in that most wanted relatively small sizes. Only four of the 32 retailers wanted cards larger than 80 square inches.

Posters were recommended as a satisfactory promotional device by nearly 60 percent of the firms, but these firms represented just over half of the total stores (Table 13). As with price cards, this result is most likely due to many larger chains' reluctance to use outside sources for POS materials.
Table 13. Promotional methods and materials recommended for tropical fruits by supermarket chain produce executives, aided recall.

\begin{tabular}{|c|c|c|c|}
\hline $\begin{array}{l}\text { Promotional } \\
\text { method }\end{array}$ & $\begin{array}{c}\text { Number of } \\
\text { firms }\end{array}$ & $\begin{array}{c}\text { Percent of firms } \\
\text { recommending } \\
\text { method }^{\mathrm{a}}\end{array}$ & $\begin{array}{c}\text { Percent of stores } \\
\text { recommending } \\
\text { method }^{\mathrm{b}}\end{array}$ \\
\hline Price cards & 45 & 62.5 & 40.9 \\
\hline Posters & 41 & 57.7 & 51.8 \\
\hline Demonstrations & 41 & 56.9 & 48.0 \\
\hline Recipes & 35 & 48.6 & 42.7 \\
\hline Brochures & 15 & 20.8 & 23.7 \\
\hline Ad slicks & 10 & 13.9 & 18.2 \\
\hline
\end{tabular}


When asked whether they would recommend in-store demonstrations for the 11 tropical fruits in question, about 57 percent of the firms answered affirmatively; these firms represented just under half of all stores. This seems surprisingly low, given the relatively high effectiveness ratings given to this promotional method. However, it is clear from several buyers' comments that they felt the high costs on in-store demonstrations would far outweigh the benefits.

Recipes distributed at the point of sale were recommended by nearly half the firms representing about 43 percent of all stores. Informational
Table 14. Price card sizes preferred by supermarkets.

\begin{tabular}{|c|c|c|c|c|}
\hline $\begin{array}{l}\text { Preferred size } \\
(\mathrm{LxW}, \text { inches })^{\mathrm{a}}\end{array}$ & $\begin{array}{c}\text { Number of } \\
\text { responses }\end{array}$ & $\begin{array}{l}\text { Percent of } \\
\quad \text { firms } \\
\text { represented }^{\mathrm{b}}\end{array}$ & $\begin{array}{l}\text { Number of } \\
\text { stores } \\
\text { represented }\end{array}$ & $\begin{array}{l}\text { Percent of } \\
\text { stores } \\
\text { represented }\end{array}$ \\
\hline $7 "$ x $11 "$ & 9 & 28 & 1,954 & 31 \\
\hline $8.5 " \mathrm{n} 11 "$ & 4 & 13 & 672 & 11 \\
\hline $5 " \times 7 "$ & 3 & 9 & 405 & 6 \\
\hline $3 "$ x 5" & 3 & 9 & 555 & 9 \\
\hline 4" x 6" & 2 & 6 & 199 & 3 \\
\hline $8 " x 11 "$ & 2 & 6 & 890 & 14 \\
\hline All other sizes ${ }^{c}$ & 9 & 28 & 1,713 & 27 \\
\hline Totals & 32 & 100 & 6,388 & 100 \\
\hline \multicolumn{5}{|c|}{$\begin{array}{l}\text { aAlthough preferences were very diverse with respect to specific dimensions, there was } \\
\text { consistency in that most wanted relatively small sizes. Only four of the } 32 \text { retailers } \\
\text { wanted price cards larger than } 80 \text { square inches. }\end{array}$} \\
\hline \multicolumn{5}{|c|}{$\begin{array}{l}\text { 'Percentages are based on } 32 \text { responses representing } 6,388 \text { stores; they do not sum to } 100 \\
\text { percent because of rounding. Retailers using only in-house POS materials were not asked } \\
\text { this question. }\end{array}$} \\
\hline
\end{tabular}

brochures were far less popular with buyers, recommended by only one-fifth of them, and representing about one-fourth of the stores (Table 13). Ad slicks were the least popular promotional item, favored by about 14 percent of the firms, but accounting for nearly 20 percent of the stores. This result is due to the greater propensity of larger chains to use newspaper advertising to promote minor items such as tropical fruit.

After the buyers had reacted to the preceding traditional promotional items and methods (Table 13), they were asked what other kinds of promotional efforts, if any, they would recommend for Florida-produced tropical fruit. Although the numbers of responses are relatively small, some of the ideas may be viable for the south Florida tropical fruit industry.

The most frequently mentioned promotional suggestion was not for a specific form of promotion, but for a cohesive, comprehensive approach (Table 15). One-fourth of the supermarket buyers suggested that Florida growers and shippers use a variety of materials that would include the full spectrum of POS materials and activities coupled with media advertising and publicity (unpaid media coverage). Several specifically recommended that Florida should attempt to develop generalized "tropical fruit" promotions that could be used for a number of different fruits rather than materials specific to one type of fruit.

Another method recommended for improving sales of Florida-produced tropical fruit was to provide consumers with nutritional information, mentioned by five buyers representing slightly over 
7 percent of the stores (Table 15). Nutritional information could be included in many other forms of materials, such as recipes, brochures, and even in in-store signs and posters where appropriate.

Magazines, televisions, and radio were each mentioned by three buyers (Table 15). For magazines, feature stories and paid ads were both recommended. Television coverage included similar recommendations, i.e., features on cooking shows and paid ads. Paid radio spots were also mentioned as a means of reaching consumers.

Buyers from three firms also recommended that the Florida tropical fruit industry also target foodservice outlets for market development. Their rationale was that restaurants would introduce the exotic fruits to consumers, who in turn would buy the fruit from retail food stores.

Several buyers suggested that sales could be increased if Florida growers and shippers improved product quality and packaging. While there is always room for improvement of the basic product and the condition in which it arrives at its retail destination, criticisms of product quality were relatively rare, as mentioned in a preceding section. With the exception of specialty bananas, poor product quality does not appear to be a significant obstacle to greater market acceptance.

The last suggestion for improving sales of Florida-grown tropical fruit, offered by two honest and perceptive buyers, was to provide more information, including product samples, to produce buyers (Table 15). All buyers interviewed had expressed familiarity with mangos, papayas, carambolas, passion fruit, and specialty bananas. However, it became obvious during the course of the interviews that many buyers were unfamiliar with many of the fruits included in this study. For example, nearly one-third of the buyers, representing 36 percent of all stores, admitted that they were unfamiliar with the sugar apple (Table 16). About one-fourth of the buyers, representing a similar proportion of stores, were unfamiliar with longans. One-fifth of the buyers were somewhat unfamiliar with mamey sapotes and about 13 percent knew little about atemoyas. Although the overwhelming majority of buyers indicated that they were familiar with lychees and guavas, four firms representing nearly 800 stores knew little about lychees and one buyer admitted to being unfamiliar with guavas.

Table 15. Miscellaneous methods for improving sales of Florida-produced open-ended responses.

\begin{tabular}{|c|c|c|c|}
\hline \multirow[b]{2}{*}{ Method } & \multicolumn{2}{|c|}{ Firms } & \multirow{2}{*}{$\begin{array}{c}\text { Percent of } \\
\text { stores }^{\mathrm{b}}\end{array}$} \\
\hline & Number & Percent $^{\mathrm{a}}$ & \\
\hline Comprehensive campaigns & 18 & 25.0 & 29.5 \\
\hline Nutritional education & 5 & 6.9 & 7.4 \\
\hline Lower prices & 4 & 5.6 & 3.9 \\
\hline Magazine stories/ads & 3 & 4.2 & 11.5 \\
\hline Television ads/cooking shows & 3 & 4.2 & 4.9 \\
\hline Radio ads & 3 & 4.2 & 3.9 \\
\hline $\begin{array}{l}\text { Introduce to consumers through } \\
\text { foodservice exposure }\end{array}$ & 3 & 4.2 & 3.7 \\
\hline Improve product quality/packing & 2 & 2.8 & 4.0 \\
\hline $\begin{array}{l}\text { Provide information/samples to } \\
\text { produce buyers }\end{array}$ & 2 & 2.8 & 2.3 \\
\hline Totals & 72 & - & -- \\
\hline $\begin{array}{l}\text { "Percentages are based upon observations } \\
\text { because of multiple responses. }\end{array}$ & from 72 fir & Percentages & t summed \\
\hline
\end{tabular}


Table 16. The number of chainstore produce executives unfamiliar with selected tropical fruits.

\begin{tabular}{lcccc}
\hline \hline Fruit $^{\mathrm{b}}$ & \multicolumn{2}{c}{ Firms } & \multicolumn{2}{c}{ Stores } \\
& No. & Percent $^{\mathrm{b}}$ & No. & Percent $^{\mathrm{c}}$ \\
Sugar apple & 24 & 32.0 & 5,454 & 36.0 \\
Longan & 20 & 26.7 & 3,744 & 24.7 \\
Mamey sapote & 15 & 20.0 & 2,231 & 14.7 \\
Atemoya & 10 & 13.3 & 1,448 & 9.6 \\
Lychee & 4 & 1.3 & 795 & 5.2 \\
Guava & 1 & & $-\mathrm{d}^{\mathrm{d}}$ & $-\mathrm{d}^{\mathrm{d}}$ \\
\hline
\end{tabular}

${ }^{2}$ All chainstore produce executives were familiar with mangos, papayas, passion fruit, specialty bananas and carambolas.

${ }^{b}$ Percentages are based upon 75 firms.

'Percentages are based upon 15,155 stores.

${ }^{\mathrm{d}}$ Data not reported to avoid disclosure.

The degree of produce buyers' unfamiliarity with these fruits is probably underestimated, because experienced professionals may be reluctant to admit to being less than expert in their knowledge. If this assumption is correct, buyer education, through direct mail, samples, personal visits and trade shows could increase total demand for lesser-known tropicals. Special efforts to educate the trade are necessary to gain access to the retail marketplace, because it is unlikely that buyers will order expensive and perishable fruits that are unfamiliar. 


\section{The Specialty Produce Wholesaler Survey}

The specialty produce wholesaler survey was conducted to determine which of the 11 targeted fruits were handled, sales trends of each fruit, the geographic sources of fruits, buyers' perceived quality of fruits from various areas, and kinds of promotional activities used for tropical fruit.

Approximately 200 specialty wholesalers throughout the U.S. were identified with the assistance of the staff of the Produce Reporter Company; the firms selected for interviewing were listed under numerous categories in The Blue Book, and included buying brokers, commission merchants, foodservices, jobbers and receivers. Specific produce specialities for these firms included "tropical produce", "mangos", "papayas", "persimmons", and "Chinese produce". At least six attempts were made to interview the head buyer of each firm, unless an outright refusal was encountered. A total of 145 firms in 20 states provided usable data. The largest numbers of cooperating firms were found in California, Florida, New York and Texas, with 57, 22, 16 and 10, respectively. These states accounted for nearly three-quarters of all cooperating specialty wholesalers. Other significant numbers were interviewed in Illinois, Pennsylvania, Massachusetts, New Jersey and Michigan with 7, 5, 4, 3 and 3, respectively. All of the specialty produce wholesalers were located in the same food distribution regions as the retail chainstores discussed in the preceding section. Slightly over half (54 percent) were located in the western region, i.e., west of the Mississippi River, and the remainder in the eastern region. About 85 percent of the specialty wholesalers in the western region were located in two states, California and Texas; California accounted for about 72 percent and Texas 13 percent. The eastern-western regions relative to the Mississippi River were defined to allow examination of regional differences in fruit availability and demand trends. The regional definition based on the Mississippi River has generally coincided with Florida's ground transportation advantage in serving markets east of the river, and western produce suppliers' transportation advantage in serving markets to the west. This regional definition also allows a rough comparison of demand trends for the populous east coast versus west coast markets.

\section{Availability of the Selected Fruits}

Availability of the 11 selected fruits through specialty produce wholesalers varied considerably among the fruits. Also, availability of some fruits was quite different between the eastern and western regions.

Mangos and papayas were by far the mostly widely available of the 11 targeted tropical fruits. Mangos were handled by about 98 percent of the specialty wholesalers in the eastern region and 90 percent of those in the western region (Table 17).

Papayas were available from about 80 percent of the wholesalers in both the eastern and western regions. However, carambola availability was much greater in the eastern region. Approximately 60 percent of the eastern region wholesalers handled carambola, compared with about 20 percent of those in the western region. Lychee availability was also greater in eastern markets, handled by nearly half of the firms, as compared with about one-fourth of the western 
wholesalers. Availability of guavas was not too dissimilar for the two regions, with about 38 percent of the eastern wholesalers carrying them as compared to 30 percent of the western firms (Table 17).

Passion fruit availability was markedly different for the two regions, with about 45 percent of the eastern region wholesalers offering it compared with only 20 percent of those in the western region. Specialty bananas were available from approximately the same percentages of specialty wholesalers in the two regions, just under 30 percent. However, mamey sapotes were available from nearly one-fourth of the firms in the eastern region, but only 10 percent of those in the western region. The availability of atemoyas and sugar

Table 17. Number of specialty wholesalers handling targeted fruits.

\begin{tabular}{|c|c|c|c|c|c|c|}
\hline \multirow[t]{2}{*}{ Fruit } & \multicolumn{2}{|c|}{ Eastern } & \multicolumn{2}{|c|}{ Western } & \multicolumn{2}{|c|}{ Overall } \\
\hline & number & percent $^{\mathrm{a}}$ & number & percent $^{\mathrm{a}}$ & number & percent $^{\mathrm{a}}$ \\
\hline Mango & 65 & 98.5 & 71 & 89.9 & 136 & 93.8 \\
\hline Papaya & 53 & 80.3 & 64 & 81.0 & 117 & 80.7 \\
\hline Carambola & 39 & 59.1 & 16 & 20.3 & 55 & 37.9 \\
\hline Lychee & 31 & 47.0 & 20 & 25.3 & 51 & 35.2 \\
\hline Guava & 25 & 37.9 & 24 & 30.4 & 49 & 33.8 \\
\hline Passion fruit & 30 & 45.5 & 16 & 20.3 & 46 & 31.7 \\
\hline Specialty banana & 18 & 27.3 & 23 & 29.1 & 41 & 28.3 \\
\hline Mamey sapote & 15 & 22.7 & 8 & 10.1 & 23 & 15.9 \\
\hline Atemoya & 14 & 21.2 & 4 & 5.1 & 18 & 12.4 \\
\hline Longan & 10 & 15.2 & 6 & 7.6 & 16 & 11.0 \\
\hline Sugar apple & 7 & 10.6 & 2 & 2.5 & 9 & 6.2 \\
\hline
\end{tabular}

${ }^{\text {a } E a s t e r n ~ a n d ~ W e s t e r n ~ r e g i o n ~ p e r c e n t a g e s ~ a r e ~ b a s e d ~ u p o n ~} 66$ and 79 firms, respectively, and overall percentages are based upon the total of 145 firms. apples was also very dissimilar for the two regions. In the east, atemoyas were offered by about 20 percent of the firms, but only 5 percent in the west. Similarly, sugar apples were available from about 11 percent of the wholesalers in the eastern region, but only 2 percent in the western region. Longans were handled by about 15 percent of the eastern region wholesalers, and by about 8 percent of those west of the Mississippi (Table 17).

Much of the disparate availability between the eastern and western region for some fruits is undoubtedly due to the phytosanitary restrictions that prohibit transportation or delivery of Floridaproduced fruit to California, Texas and Arizona. Specifically, annonas (atemoyas and sugar apples) and passion fruit grown in Florida cannot be shipped to these states because of the Caribbean fruit fly, Anastrephasuspensa. There are presently no approved treatments which would allow these fruits to enter those states (Paul Hornby, 1997). (Appendix Table D-1). This limitation certainly has a detrimental effect on Florida's market potential for these fruits in some of the most populous ethnic markets of the west. Mamey sapote shipments to these state are also prohibited, but efforts continue to lift the quarantine of this fruit. 
Also, because of the Caribbean fruit fly threat, carambolas, guavas, mangos and papayas grown in Florida must be subjected to approved treatments in order to be shipped to these states. Carambolas receive a cold treatment ( 12 days at $34^{\circ} \mathrm{F}$.), while guavas, mangos and papayas receive various hot water treatments. All of the treatments reduce shelf life and may adversely affect product quality, but the effects on carambola are generally less detrimental. Lychees and longans, as long as they are produced under commercial conditions, may enter California, Texas and Arizona without treatment. "Commercial" fruit is defined as "that fruit which has been commercially produced, cleaned, sorted and packed. The foregoing results in fruit that is free of splits or cracks, among other things, and thus without risk of harboring Caribbean fruit fly" (California Department of Agriculture, 1996). Also, specialty bananas are not restricted because they are not a host plant to the Caribbean fruit fly. In addition to the phytosanitary restrictions, distance to market is another detriment that may make expansion of western markets more difficult. Aside from obviously greater shipping costs, ground transportation may be too rough and take too long for fragile fruit with relatively short shelf lives. For these fruits, development of markets closer to south Florida is the most promising alternative.

With the exception of mangos and papayas, the relatively limited availability of the targeted fruits in the eastern region indicates markets that are far from saturated, markets that offer opportunity for expansion. The western region also appears to hold much promise for high value, high quality fruits that require no treatment such as lychee and longan, and fruit that can withstand the adverse effects of treatment without significant loss of quality, such as carambola.

\section{Sales Trends}

In general, produce wholesalers' reported sales trends for the previous two years were positive. For nine of the selected fruits, more than 90 percent of the wholesalers reported either stable or increasing sales trends. For the two remaining fruits, over 85 percent noted stable or increasing sales. For every one of the 11 fruits, the percentages of wholesalers reporting upward trends in sales were considerably greater than those reporting declining sales (Table 18).

Sales trends were examined for each of the 11 fruits by region i.e., eastern (east of the Mississippi River) and western using $\chi^{2}$ analysis. Because of the extremely small numbers of wholesalers reporting declining trends, the $\chi^{2}$ analyses only examined the frequency distributions reporting stable or increasing sales trends by region. For most fruits, there were no statistically significant differences in sales trends between the two regions at commonly accepted levels of probability. However, at marginally higher probability levels, there were significant regional differences in reported sales trends for carambola. There were statistically significant regional differences in sales trends for lychee and passion fruit at the 0.1 and 0.01 probability levels, respectively. (Table 18, Appendix Table D-2). 
Table 18. Sales trends for targeted fruits, reported by specialty produce wholesalers.

\begin{tabular}{|c|c|c|c|c|c|c|c|}
\hline \multirow[b]{3}{*}{ Fruit } & \multirow{3}{*}{$\begin{array}{c}\text { Number } \\
\text { reporting } \\
\text { a trend }\end{array}$} & \multicolumn{6}{|c|}{ Trend } \\
\hline & & \multicolumn{2}{|c|}{ Down } & \multicolumn{2}{|c|}{ Stable } & \multicolumn{2}{|c|}{ Up } \\
\hline & & number & percent & number & percent & number & percent \\
\hline Mango & 131 & 13 & 9.9 & 29 & 22.1 & 89 & 67.9 \\
\hline \multicolumn{8}{|l|}{ Carambola $^{\mathrm{a}}$} \\
\hline Eastern region & & 0 & 0.0 & 11 & 29.7 & 26 & 70.3 \\
\hline Western region & & 1 & 7.1 & 7 & 50.0 & 6 & 42.9 \\
\hline Overall & 51 & 1 & 2.0 & 18 & 35.3 & 32 & 62.7 \\
\hline Papaya & 114 & 10 & 8.8 & 36 & 31.6 & 68 & 59.6 \\
\hline Banana & 39 & 1 & 2.6 & 19 & 48.7 & 19 & 48.7 \\
\hline Longan & 16 & 0 & 0.0 & 9 & 56.3 & 7 & 43.8 \\
\hline \multicolumn{8}{|l|}{ Lychee $^{\mathrm{b}}$} \\
\hline Eastern region & & 1 & 3.6 & 19 & 67.9 & 8 & 28.6 \\
\hline Western region & & 3 & 15.8 & 7 & 36.8 & 9 & 47.4 \\
\hline Overall & 47 & 4 & 8.5 & 26 & 55.3 & 17 & 36.2 \\
\hline Guava & 46 & 4 & 8.7 & 27 & 58.7 & 15 & 32.6 \\
\hline \multicolumn{8}{|l|}{ Passion fruit ${ }^{\mathrm{c}}$} \\
\hline Eastern region & & 2 & 7.1 & 21 & 75.0 & 5 & 17.9 \\
\hline Western region & & 0 & 0.0 & 6 & 40.0 & 9 & 60.0 \\
\hline Overall & 43 & 2 & 4.7 & 27 & 62.8 & 14 & 32.6 \\
\hline Mamey sapote & 21 & 3 & 14.3 & 12 & 57.1 & 6 & 28.6 \\
\hline Atemoya & 18 & 2 & 11.1 & 12 & 66.7 & 4 & 22.2 \\
\hline Sugar apple & 8 & 0 & 0.0 & 7 & 87.5 & 1 & 12.5 \\
\hline
\end{tabular}

${ }^{a}$ Chi-square analysis indicates regional differences in stable and upward trend distributions are statistically significant, $\mathrm{X}^{2}=2.428, \mathrm{P}=0.119$ ${ }^{\mathrm{b}} \mathrm{Chi}$-square analysis indicates regional differences in stable and upward trend distributions are statistically significant, $\mathrm{X}^{2}=2.978, \mathrm{P}=0.084$ ${ }^{c} \mathrm{Chi}$-square analysis indicates regional differences in stable and upward trend distributions are statistically significant, $\mathrm{X}^{2}=7.031, \mathrm{P}=0.01$.

\section{Wholesalers' Geographic Sources and Quality Ratings of Selected Fruits}

For each of the 11 selected fruits, wholesalers were asked to indicate their usual geographic sources and to rate the overall quality from each source using a rating scale where 10 represented "excellent" and 1 indicated "extremely poor". For some fruits and sources, very few respondents provided ratings, which precludes rigorous statistical comparisons of mean ratings. Thus caution must be exercised in interpreting the results, especially where small numbers of observations are reported (Table 19). Another word of caution is in order with respect to buyers' reported sources of fruit in Table 19 and Appendix Table D-3. In a few cases, the buyers' responses were "educated" guesses which appear to be incorrect; these responses may also reflect an intermediate geographic source of fruit that originated elsewhere. 
Table 19. Wholesalers' ratings of sources of fruit.

\begin{tabular}{|c|c|c|c|c|c|c|c|c|c|c|c|c|c|c|c|c|c|c|c|c|c|c|}
\hline \multirow[b]{3}{*}{ Source } & \multicolumn{22}{|c|}{ Type of Fruit } \\
\hline & \multicolumn{2}{|c|}{ Atemoya } & \multicolumn{2}{|c|}{ Banana } & \multicolumn{2}{|c|}{ Carambola } & \multicolumn{2}{|c|}{ Guava } & \multicolumn{2}{|c|}{ Lychee } & \multicolumn{2}{|c|}{ Longan } & \multicolumn{2}{|c|}{$\begin{array}{c}\text { Mamey } \\
\text { Sapote }\end{array}$} & \multicolumn{2}{|c|}{ Mango } & \multicolumn{2}{|c|}{ Papaya } & \multicolumn{2}{|c|}{$\begin{array}{c}\text { Passion } \\
\text { Fruit }\end{array}$} & \multicolumn{2}{|c|}{$\begin{array}{l}\text { Sugar } \\
\text { Apple }\end{array}$} \\
\hline & $\mathrm{n}$ & $\begin{array}{l}\text { mean } \\
\text { rating }\end{array}$ & $\mathrm{n}$ & $\begin{array}{l}\text { mean } \\
\text { rating }\end{array}$ & $\mathrm{n}$ & $\begin{array}{l}\text { mean } \\
\text { rating }\end{array}$ & $\mathrm{n}$ & $\begin{array}{l}\text { mean } \\
\text { rating }\end{array}$ & $\mathrm{n}$ & $\begin{array}{l}\text { mean } \\
\text { rating }\end{array}$ & $\mathrm{n}$ & $\begin{array}{l}\text { mean } \\
\text { rating }\end{array}$ & $\mathrm{n}$ & $\begin{array}{l}\text { mean } \\
\text { rating }\end{array}$ & $\mathrm{n}$ & $\begin{array}{l}\text { mean } \\
\text { rating }\end{array}$ & $\mathrm{n}$ & $\begin{array}{l}\text { mean } \\
\text { rating }\end{array}$ & $\mathrm{n}$ & $\begin{array}{l}\text { mean } \\
\text { rating }\end{array}$ & $\mathrm{n}$ & $\begin{array}{l}\text { mean } \\
\text { rating }\end{array}$ \\
\hline Arizona & & & & & & & & & & & & & & & 2 & 8.0 & & & & & & \\
\hline Bahamas & & & & & & & & & & & & & & & & & 2 & 8.0 & & & & \\
\hline Belize & & & & & & & & & & & & & & & 1 & 7.0 & 6 & 7.3 & & & & \\
\hline Brazil & & & & & & & & & & & & & & & 33 & $8.3 *$ & & & & & & \\
\hline California & 2 & 7.0 & 2 & 9.0 & 3 & 7.7 & 11 & 7.4 & 2 & 8.5 & 1 & 6.0 & & & & & & & 13 & $7.9 *$ & & \\
\hline "Carribean" & & & & & & & & & 1 & 9.0 & & & & & & & 2 & 9.5 & & & & \\
\hline $\begin{array}{l}\text { "Central } \\
\text { America" }\end{array}$ & & & & & & & & & & & & & & & 3 & 8.7 & 3 & 7.3 & & & & \\
\hline Chile & & & & & & & & & 1 & 6.0 & & & & & 4 & $6.5 *$ & & & 1 & 8.0 & & \\
\hline Columbia & & & & & & & & & & & & & & & 1 & 8.0 & & & & & & \\
\hline Costa Rica & & & 5 & 7.4 & & & & & & & & & & & 2 & 7.5 & 1 & 3.0 & & & & \\
\hline $\begin{array}{l}\text { Dominican } \\
\text { Rep. }\end{array}$ & & & 1 & 4.0 & & & & & & & & & & & & & 15 & $6.7 \div$ & & & & \\
\hline Ecuador & & & 11 & 8.3 & & & & & & & & & & & 18 & $6.2 * *$ & & & & & & \\
\hline El Salvador & & & & & & & & & & & & & & & 1 & 8.0 & & & & & & \\
\hline Florida $^{\mathrm{a}}$ & 10 & 7.8 & 3 & 6.7 & 39 & 7.7 & 19 & 7.8 & 24 & 8.4 & 9 & 7.5 & 9 & 8.4 & 26 & 7.5 & 11 & 8.4 & 21 & 6.9 & 6 & 8.2 \\
\hline Guatemala & & & 3 & 7.0 & & & 1 & 6.0 & & & & & & & 17 & 7.4 & 1 & 6.0 & & & & \\
\hline Haiti & & & & & & & & & & & & & & & 23 & 6.7 & & & & & & \\
\hline Hawaii & & & & & 5 & 6.8 & 1 & 10.0 & 1 & 10.0 & & & & & 1 & 5.0 & 43 & 8.7 & & & & \\
\hline Honduras & & & 4 & 7.5 & & & & & & & & & & & & & & & & & & \\
\hline Israel & & & & & & & & & 3 & 8.3 & & & & & & & & & & & & \\
\hline Jamaica & & & & & & & & & & & & & & & 1 & 10.0 & 25 & 7.6 & & & & \\
\hline Malaysia & & & & & 1 & 7.0 & & & & & & & & & & & & & & & & \\
\hline Mexico & & & 11 & 7.2 & & & 5 & 7.2 & 12 & $6.9 *$ & 1 & 10.0 & 1 & 8.0 & 98 & 7.5 & 45 & $7.3 \div$ & & & & \\
\hline New Zealand & & & & & & & 6 & 8.6 & & & & & & & 2 & 8.5 & & & 19 & $9.0 * *$ & & \\
\hline Nicaragua & & & & & & & & & & & & & & & 3 & $5.7 \div$ & & & & & & \\
\hline Panama & & & 2 & 7.0 & & & & & & & & & & & & & & & & & & \\
\hline Peru & & & & & & & & & & & & & & & 37 & 6.9 & & & & & & \\
\hline Phillippines & & & 1 & 9.0 & & & & & & & & & & & & & 1 & 7.0 & & & & \\
\hline Puerto Rico & & & 1 & 10.0 & & & & & & & & & & & 4 & 7.0 & 1 & 7.0 & & & & \\
\hline "SE Asia" & & & & & & & & & & & 1 & 7.0 & & & & & & & & & & \\
\hline St. Vincent & & & & & & & & & & & & & & & 1 & 4.0 & & & & & & \\
\hline "S. America" & 1 & 7.0 & 4 & $9.3 *$ & 2 & 7.5 & & & & & & & 1 & 7.0 & 11 & 7.7 & 1 & 5.0 & 2 & 7.5 & & \\
\hline Texas & & & & & & & & & & & & & & & 1 & 8.0 & 1 & 7.0 & & & & \\
\hline Thailand & & & & & & & & & 1 & 8.0 & & & & & & & & & & & & \\
\hline Venezuela & & & 3 & 8.3 & & & & & & & & & & & 17 & \begin{tabular}{|l|}
7.0 \\
\end{tabular} & & & & & & \\
\hline
\end{tabular}

${ }^{a} \mathrm{~A}$ t-test was used to compare mean ratings of specific Florida-produced fruits with those of fruits originating in other areas where there were sufficient observations. An F test was used to determine whether pooled variances were appropriate. The symbols $\ddagger$, $*$ and $* *$ indicate the means that are significantly different from Florida's at the $0.10,0.05$ and 0.001 probability levels. Mean ratings without superscripts indicate that they were not significantly different from Florida's ratings or there were too few observations for meaningful comparisons. 


\section{Atemoya}

Of the 18 wholesalers reporting atemoya sales, 12 reported purchasing Florida-grown atemoya, two purchased California-grown atemoya, one purchased atemoya from Mexico, one purchased atemoya grown in South America, and five were not aware of the fruit's origin. (Appendix Table D-3). Several California wholesalers reported receiving atemoyas from Florida, but because of phytosanitary restrictions, this is very unlikely. This is another indication that wholesale buyers have limited knowledge about some of the more obscure tropical fruits. On the scale described above, wholesalers' average rating for Florida was 7.8. The few ratings for California and "South American" atemoyas were somewhat lower (Table 19).

\section{Specialty bananas}

Of the 39 wholesalers reporting specialty banana sales, only three reported getting any of them from Florida. Only one of the six Florida wholesalers reported Florida as a source. (Appendix Table D-3). East coast wholesalers said they received the bulk of their supplies from South and Central America, with Ecuador and Venezuela among the most frequently mentioned sources. Costa Rica, Honduras, Puerto Rico, and the Dominican Republic were also mentioned as sources. Most wholesalers in the western region received the bulk of their specialty bananas from Mexico and Ecuador, with a few reporting Guatemala, Venezuela, Panama, and the Phillippines as sources.

Only three firms rated Florida-produced specialty bananas, so the average rating of 6.7 may not be very accurate. Ratings from other major sources such as Ecuador and Mexico had relatively high ratings of 8.3 and 7.2, respectively (Table 19). This indicates that quality competition, especially from Ecuador, may be formidable.

\section{Carambola}

Florida was the overwhelming leader as a source of carambola in both the eastern and western regions. Over 40 of the 51 wholesalers responding to this question reported purchasing most all carambola from Florida sources. Other sources of carambola included California (probably Malaysian), Hawaii, Malaysia, "South America" and Mexico. Wholesalers rated Florida-grown carambola at 7.7, and Hawaiian carambola at 6.5 (Table 19, Appendix Table D-3).

\section{$\underline{\text { Guava }}$}

Florida was the predominant supplier of guava to eastern region wholesalers. However, a few respondents in the east said that New Zealand, Guatemala, and Mexico were their major sources. In the western region, California was the predominant source, followed by Mexico. A few western wholesalers also mentioned New Zealand and Florida as sources (Appendix D-3). Florida average overall quality rating was 7.8 on the 10 point scale, compared with 7.4 for California. Mexico's average rating was 7.2, while New Zealand's was 8.6. Thus, it appears that the quality of Floridaproduced guavas is generally acceptable to the wholesale trade, although rated somewhat lower than guavas from New Zealand (Table 19). 


\section{Lychee}

In the eastern region, Florida was mentioned as the primary source by 85 percent of the firms reporting a geographic source for lychees. Mexico was mentioned as the primary source by two wholesalers. Chile and Hawaii were also mentioned as a primary source by one firm each.

Among western region wholesalers, Mexico was the primary source for nearly 60 percent. Florida was the primary source of lychees for 3 of 14 firms (about 20 percent) of the western region wholesalers, and Thailand was cited as a major supplier by one western wholesaler. Israel, Australia and New Zealand were also mentioned as minor sources by several wholesalers. (Appendix Table D-3).

The overall quality ratings of Florida lychees was 8.4 on the 10 point scale $(10=$ excellent $)$, which compares favorably to other major sources (Table 19).

\section{$\underline{\text { Longan }}$}

Because of the relatively small numbers of firms handling longan, data on sources of supplies are also limited. Nevertheless, Florida appears to be the major source nationwide, although several California wholesalers mentioned "southeast Asia" and Mexico as their major sources. (Appendix Table D-3). The average quality rating of Florida longans was 7.5; there were too few quality ratings of fruit from other sources to be meaningful.

\section{Mamey sapote}

Mamey sapotes were handled by very few firms in the western region. Several wholesalers in California were unsure as to the origin of their mamey sapote, but one said Mexico and another said Costa Rica was their primary source. Almost all of the eastern region wholesalers said Florida was their primary source of mamey sapotes. Mexico was mentioned as a secondary supplier by two eastern region firms. (Appendix Table D-3).

The nine firms that rated Florida mamey sapote gave relatively high ratings; the average was 8.4 on the 10 point scale. Again, there were too few ratings on fruit from other sources to provide meaningful comparisons.

\section{Mango}

The geographical sources of mangos were markedly different for the western and eastern regions. Although Mexico was found to be by far the most dominant supplier in both regions, Mexico has considerably more competition in the eastern region. In the western region, about 85 percent of the wholesalers said Mexico was their sole or primary supplier, with an additional 5 percent indicating that Mexico was a significant secondary supplier. Brazil, Peru, Guatemala, and Chile were mentioned as primary sources by small numbers of firms along with "Arizona", Hawaii, "Texas" and Florida. Those mentioning Arizona and Texas as sources were probably referring to trans-shipped Mexican-grown mangos. Only one California-based firm said Florida was its primary 
source of mangos, although two western region firms said Florida was a secondary source. Other major suppliers to the western region, although on a secondary or basis, included Peru, Brazil and Ecuador. Approximately 15 to 20 percent of the western wholesalers reported receiving a portion of their mango supplies from one or more of these countries. (Appendix Table D-3). Mexico was identified as the primary mango supplier for approximately 40 percent of the eastern region wholesalers, and an additional 25 percent cited Mexico as a secondary source. However, many other areas, including Florida, the Caribbean, and countries in Central and South America were also mentioned as primary sources.

Approximately 13 percent of the eastern region firms said Florida was their primary supplier of mangos, and an additional 21 percent said they received some but less than half of their mango supplies from Florida. Thus, about one-third of the eastern region wholesalers received some Florida mangos. (Appendix Table D-3).

In addition to Mexico and Florida, other countries that were mentioned as major suppliers by eastern region wholesalers included Haiti, Brazil, Guatemala, and Venezuela. Additionally, Puerto Rico and St. Vincent were also mentioned as major supply areas by a few firms. The most frequently mentioned secondary supply areas (in addition to Mexico and Florida) were Brazil, Peru and Venezuela, each mentioned by about one-fifth of all eastern wholesalers. Haiti and Guatemala were also mentioned as secondary suppliers by 17 and 16 percent of the wholesalers, respectively. Other minor supply areas mentioned were Ecuador, Chile, New Zealand, Nicaragua, Belize, and Jamaica. (Appendix Table D-3).

\section{Papaya}

The geographical source of papayas were also quite different for the western and eastern regions. In the western region, nearly half the wholesalers indicated that Mexico was their major source, while nearly 40 percent received the bulk of their papaya supplies from Hawaii. Florida was cited as a primary source by only two firms (about 3 percent). The Dominican Republic the Phillippines, and Texas were mentioned as primary sources by small numbers of firms (Appendix Table D-3).

In the eastern region, Jamaica was mentioned as a primary supplier by one third of the 51 firms reporting sources of papayas. Hawaii was also identified as a major supplier, mentioned as the leading source by 27 percent of the firms. Other primary sources included the Dominican Republic, Mexico and Florida were mentioned by 16, 14 and 12 percent respectively. A few firms indicated that their primary suppliers were Belize, Costa Rica and the Bahamas (Table D-3). Overall, quality ratings of Florida papayas compared favorably with most of the geographic sources mentioned. On the rating scale where 10 represented "excellent" and 1 "extremely poor", Florida papayas received an average rating of 8.4. Wholesalers rated Hawaiian papayas slightly higher; the mean rating was 8.7, but the difference between the rating for Florida and Hawaii produced papayas was not statistically significant (Table 19). Florida's average papaya quality rating of 8.4 was greater than those of other major supply areas. For example, the quality ratings of papayas from Mexico and the Dominican Republic were only 7.3 and 6.7, respectively, and compared with Florida the differences were statistically significant. The mean quality rating of Jamaican papayas was only 7.6, but this rating was not statistically different from Florida's (Table 19). 


\section{Passion Fruit}

Geographic sources of passion fruit were quite different for the eastern and western regions. In the west, California and New Zealand were the two predominant sources; one west coast firm reported getting small quantities of passion fruit from Florida. No other geographic sources were given by western region wholesalers. However, Florida was the one predominant source of passion fruit for wholesalers in the eastern region. New Zealand was mentioned as the primary source of passion fruit by approximately one-fifth of the eastern region respondents. California, "Central America" and "South America" were also mentioned by small numbers of wholesalers (Appendix Table D-3). Quality ratings of Florida-produced passion fruit did not compare very favorably with ratings of fruit from other production areas. The average rating of Florida's passion fruit was 6.9 on the 10-point scale $(10=$ excellent, $1=$ very poor $)$ compared with 9.0 for New Zealand and 7.9 for California. The mean differences for Florida vs. New Zealand and California were statistically significant (Table 19).

\section{$\underline{\text { Sugar apple }}$}

As mentioned in a previous section, distribution of sugar apples was relatively limited. Of nine specialty wholesalers handling sugar apples, only six identified their geographic source and Florida was the only source mentioned. The average quality rating was 8.2 on the 10-point scale, which compares favorably with quality ratings of the other fruits (Table 19).

\section{Wholesalers' Suggestions for Improving South Florida's Tropical Fruit Sales}

Wholesalers were asked for specific ways that South Florida growers and shippers could improve tropical fruit sales. Wholesalers were asked for suggestions only for each of the Floridagrown fruits they carried. Thus, the widely available fruits such as mango and papayas elicited many ideas, but the less-well-known fruits few suggestions. The rationale for asking for suggestions from only those wholesalers carrying Florida fruits was to obtain objective feedback from those with firsthand experience with specific types of Florida-grown fruit. There were many similarities in suggestions across fruits. Additionally, the suggestions tended to fall into four general categories, i.e., increased promotion, lowered prices, supply related issues, and quality considerations. Findings for each of the 11 fruits follow.

\section{$\underline{\text { Atemoya }}$}

Only 10 of the 18 wholesalers carrying atemoyas offered suggestions for improving sales. However, the overwhelming consensus, expressed by 7 or the 10 wholesalers, was increase consumer awareness and demand through promotional activities. One wholesaler expressed concern about prices being too high, and two mentioned supply problems. One complained about the shortness of the season, and another about limited supplies during Florida's season. 
Quality did not appear to be a major impediment to Florida's atemoya sales, but two wholesalers specifically mentioned cold damage as a problem. One also mentioned the need for handling and storage information to obtain satisfactory shelf life while maintaining product quality. Two others urged Florida growers and shippers to market only the highest quality possible on a consistent basis as a way to increase sales (Table 20).

\section{Specialty banana}

Nearly half of the 18 wholesalers offering suggestions for greater sales indicated that promotion was the key. Several said prices were too high, but only one wholesaler complained of limited supplies.

Four of the 18 wholesalers suggested improving quality. One wholesaler specifically complained that Florida specialty bananas frequently arrived bruised and overpriced (Table 20).

\section{Carambola}

About 40 percent of the wholesalers offering suggestions for increased carambola sales mentioned the need for increased promotion. In addition to educating consumers as to carambola's basic qualities and uses, several wholesalers suggested that promotional messages stress the fruit's origin, i.e., "Florida" and "U.S.A." Because of some consumers' concerns about pesticide residues and perceived sanitation problems associated with imported produce, domestic point of origin information could enhance sales.

Sixteen percent expressed the viewpoint that lower prices would encourage consumers to try it, thereby increasing demand. About one-fifth of the wholesalers cited limited supplies and the length (shortness) of the season as significant impediments to increased sales.

Nearly one-third of the wholesalers suggested quality improvements as a way to increase carambola sales. The most frequent quality complaint was damaged fruit particularly bruised ribs. Several viewed shipment of tart varieties as a quality problem; these wholesalers expressed the view that consumers do not like the tart varieties, and that tart varieties undermine consumer acceptance of the sweet varieties. Other suggestions for quality improvements including shipping only mature fruit and culling asymmetrical fruit. Several wholesalers also mentioned that fruit quality could be improved if some alternative to the currently used cold treatment could be utilized.

\section{Guava}

Nearly 60 percent of the wholesalers handling guavas felt that the fruit was poorly known by consumers, and that increased promotion was the way to increase sales. High prices were also mentioned as a detriment to increased sales by 13 percent of the respondents and thirty-five percent felt that improved quality would help. Specific quality problems mentioned were immature fruit, overripe or rotten fruit and inconsistent sizes. Only one of the 23 specialty wholesalers complained of supply problems (Table 20). 


\section{Lychee}

Nearly one-third of the wholesalers recommended increasing promotional activities for lychees. Several felt that emphasizing "Florida" or the "USA" would have a positive effect on some consumers. Nearly one-fifth felt that lower prices would induce more people to try and buy lychees. Slightly over one-third of the wholesalers cited the extremely short season and limited supplies as major limiting factors. Nearly 30 percent mentioned quality improvement as the key to increased sales. Quality complaints included fruit being overripe, short shelf life, and inconsistent sizes and degrees of ripeness within cartons. Several wholesalers stressed the importance of extremely high quality demanded by Asian consumers, emphasizing their preference for the red color which conveys freshness (Table 20).

\section{$\underline{\text { Longan }}$}

Wholesalers' suggestions for improving longan sales were very similar to those for other tropical fruits. Forty percent felt that additional promotion was necessary, and 20 percent were concerned that prevailing price levels were too high to encourage greater consumption. Thirty percent were concerned that the longan season was too short and supplies too limited. A similar number of wholesalers recommended quality improvements, such as large-sized, "export quality" fruit (Table 20).

\section{Mamey sapote}

Eight of the ten wholesalers offering suggestions for greater sales of Florida-grown mamey sapotes cited the need for more consumer education and promotion. One of the ten wholesalers mentioned high prices as a problem, but several mentioned limited supplies as a detriment to greater sales. Several felt that maintaining high quality standards would improve sales although no specific quality problems were mentioned (Table 20).

\section{Mango}

Because of the widespread availability of mangoes, a relatively large number of the produce wholesalers offered suggestions for improving sales of Florida grown mangos. Seventy-five wholesalers offered usable suggestions, and comments from an additional 16 were excluded because they were unfamiliar with Florida fruit. The 16 wholesalers not familiar with Florida fruit were primarily from states importing mangos from Mexico.

Despite the widespread availability and apparent popularity of mangos, nearly one-fourth of the wholesalers recommended additional promotion for enhancing consumer demand; there was a pervasive perception by many wholesalers that mangos were still an ethnic item that appealed primarily to Hispanics and Asians and that promotion was needed to develop the mainstream market. 
High prices were mentioned as an impediment to greater sales of Florida mangos by 20 percent of the wholesalers. Although some of the wholesalers indicated that lowering mango prices in general would stimulate consumer demand, there was a widespread perception among wholesalers that prices for Florida grown mangos were too high relative to prices of imported mangos, particularly those from Mexico.

Nearly sixty percent of the responding wholesalers indicated that improvements in fruit quality or package improvements could improve the sales performance of Florida mangos. About 10 percent only gave vague recommendations to "improve quality", but 20 percent of all respondents cited specific negative product attributes including anthracnose, immature (green) fruit, poor taste, and damage due to hot water treatment for fruit fly control. Additionally, nearly 20 percent of all respondents felt that Florida growers and shippers could increase sales by growing varieties that better met market demand. Slightly over half of these suggested that there was a greater demand among mainstream consumers for blush varieties, but several others expressed a greater need for green-skinned varieties for Asian markets. One wholesaler complained that Florida mangos were generally too large.

Ten of the 75 responding wholesalers expressed the view that Florida sales could be increased by improving packing practices. Several complained of variation within packages with respect to fruit size, color and ripeness. Several wholesalers also said that fruit count sometimes differed from that indicated on the container. Four wholesalers said that some of the packaging materials used by Florida shippers was too weak to withstand the rigors of shipping, resulting in damaged fruit. Additionally, several of these said the cartons were "ugly" and sometimes mislabeled. One respondent suggested that Florida shippers standardize mango grades and cartons. Supply problems for Florida-grown mangos were mentioned by nine of the 75 wholesalers (12 percent). Although a few mentioned limited or erratic supplies as a problem, the majority suggested extending the season as a means of increasing total sales. Cultivar development and evaluation may be the key to achieving a longer season and better eating qualities.

\section{Papaya}

Because of prevailing importing practices and marketing patterns, the wholesalers' evaluations of papayas from "Florida" are likely to reflect a mix of off-shore produced small fruit and tree Florida-grown papayas which tend to be larger. In any case, forty-one wholesalers offered suggestions for improving sales of Florida-sourced papayas. Nearly half, 49 percent, felt that additional promotional efforts were needed (Table 20). Nearly 30 percent felt that Florida's papaya prices were too high, and inferred that lower prices would result in greater consumer demand. Several west coast wholesalers indicated that Florida papayas were usually not competitive with those from Hawaii because of transportation costs, but quality considerations were also found to be a major factor. Nearly one-fourth of the responding wholesalers felt that Florida papaya growers and shippers could increase their market share by improving fruit quality. Other current quality complaints include bruised or otherwise damaged fruit, and underripe or immature fruit. Size was also an issue with some wholesalers, a few complained that Florida-grown papayas were generally too small, but an equal number said they were too large. One wholesaler said he had received a 10 
pound fruit in one shipment. When discussing quality considerations, a relatively high proportion of the wholesalers expressed a strong preference for Hawaiian papayas. About 37 percent offered no encouragement to Florida growers and shippers at all. These wholesalers viewed Hawaii's papaya quality as superior to Florida's because of varietal differences, and were unwilling to entertain the idea of buying Florida papayas. An additional 12 percent said they would buy papayas from Florida if improved varieties similar to those grown in Hawaii were available. Thus, there was substantial anecdotal evidence from the trade that Hawaiian varieties are superior to those grown in Florida. Based on these findings, developing improved cultivars adapted to south Florida will be necessary to enhance Florida papaya growers' competitive position in the U.S. market.

Seven of the 41 responding wholesalers felt that Florida papaya production was too limited. Most reported limited supplies during Florida's production season, but one suggested extending the season if possible.

\section{$\underline{\text { Passion fruit }}$}

Twenty-nine wholesalers offered suggestions for improving passion fruit sales. Over onefourth of the respondents thought that increased promotion was the key to greater sales. One wholesaler summed up the need for consumer education and promotion with the statement "it [passion fruit] is an ugly, misunderstood fruit."

Only two of the 29 responding wholesalers (5 percent) expressed concern that passion fruit was overpriced, and only three ( 7 percent) cited supply problems as a significant limitation to greater sales (Table 20). About one-forth of the wholesalers suggested quality improvement. Several made general recommendations for shipping "highest quality", "export quality" fruit, but about 20 percent of the wholesalers mentioned specific quality problems that, if overcome, could improve sales of Florida-grown passion fruit. The most frequent quality complaint was overripe, wrinkled fruit. There was a definite preference for plump, smooth-skinned, blemish-free fruit. There is a perception among some produce handlers that even slight wrinkles reduce the perception of freshness and adversely affect sales. Several other complaints about passion-fruit "quality" also indicate a lack of understanding about the basic attributes of the fruit; a few complained of the "slimy" texture of the pulp and the over abundance of seeds.

One wholesaler stated that passion fruit was "overrated" and another indicated that passion fruit had "poor sales potential." These comments, coupled with misunderstandings about "wrinkles" and other produce attributes indicate that some educational efforts should be directed toward the trade in order to develop the passion-fruit market.

\section{$\underline{\text { Sugar apple }}$}

Only five wholesalers gave suggestions for improving sales of Florida-grown sugar apples. Three of the five recommended increased promotion, and two suggested improved product quality. One also mentioned that limited supplies were a serious impediment to market development (Table 20). 
Table 20. Specialty produce wholesalers' suggestions for improving sales of selected tropical fruit grown in south Florida.

\begin{tabular}{|c|c|c|c|c|c|}
\hline Fruit & $\begin{array}{l}\text { Number of } \\
\text { respondents }\end{array}$ & $\begin{array}{c}\text { Increase } \\
\text { promotion }\end{array}$ & $\begin{array}{l}\text { Improve } \\
\text { quality }\end{array}$ & $\begin{array}{c}\text { Increase/stabilize } \\
\text { supplies }\end{array}$ & $\begin{array}{l}\text { Lower } \\
\text { prices }\end{array}$ \\
\hline & & \multicolumn{4}{|c|}{ 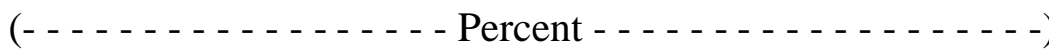 } \\
\hline Atemoya & 10 & 70 & 40 & 20 & 10 \\
\hline $\begin{array}{r}\text { Specialty } \\
\text { bananas }\end{array}$ & 18 & 44 & 22 & 6 & 11 \\
\hline Carambola & 32 & 41 & 31 & 19 & 16 \\
\hline Guava & 23 & 57 & 35 & 4 & 13 \\
\hline Lychee & 28 & 32 & 29 & 36 & 18 \\
\hline Longan & 10 & 40 & 30 & 30 & 20 \\
\hline $\begin{array}{r}\text { Mamey } \\
\text { sapote }\end{array}$ & 10 & 80 & 20 & 20 & 10 \\
\hline Mango & 75 & 23 & 60 & 11 & 20 \\
\hline Papayas & 41 & 49 & 49 & 17 & 27 \\
\hline $\begin{array}{l}\text { Passion } \\
\text { fruit }\end{array}$ & 29 & 27 & 39 & 7 & 5 \\
\hline $\begin{array}{l}\text { Sugar } \\
\text { apple }\end{array}$ & 5 & 60 & 40 & 20 & 0 \\
\hline
\end{tabular}

Percentages are based upon the total number of respondents giving one or more suggestions. 


\section{SUMMARY}

The basic objective of this study was to improve the efficiency of the marketing system for tropical fruits produced in south Florida and to formulate viable market development strategies for 11 selected fruits thought to have the greatest commercial potential. The 11 fruits were mangos, carambola, lychee, papaya, mamey sapote, specialty bananas, longan, guava, passion fruit, atemoya, and sugar apple. These fruits were selected for study by the Board of Directors of Florida Tropical Fruit Growers of South Florida, Inc.

To meet the study's objectives, three telephone surveys were conducted. The first targeted growers and shippers in south Florida, primarily in Dade County. The second survey focused on major food retailers in geographic areas of the U.S. with the 25 highest concentrations of Asian and Hispanic residents. These areas and retailers were identified by using Progressive Grocer's Marketing Guidebook and detailed population data from the 1990 U.S. Census. The third survey obtained data and suggestions for marketing tropical fruit from a nationwide sample of specialty produce wholesalers listed in The Blue Book.

South Florida, particularly the southernmost part of Dade County, contains a very high proportion of the state's tropical fruit. Prior to Hurricane Andrew in August of 1992, nearly 40 different species of fruits were produced in the region, twenty of them on a commercial scale. Before the hurricane, there were over 20,000 acres of tropical fruit groves in Dade County, but only about 13,000 acres at the end of 1994, a 35 percent reduction. Groves of avocados, Persian limes and mangos were particularly hard hit by the storm. Acreages of avocados, limes, and mangos were found to be 33, 57 and 36 percent below pre-hurricane levels. In the months following the hurricane, there was speculation that some grove land formerly devoted to avocados, limes and mangos would be planted to minor, less-well-known fruits included in the eleven mentioned above.

A survey of all known commercial tropical fruit growers in south Florida was undertaken to determine the magnitude of acreage shifts to minor fruits and thus the urgency to develop more aggressive market development programs for these fruits. The grower survey revealed some acreage shifts, but none that would require major redirection of marketing activities in order to prevent catastrophically low grower prices as the result of massive overproduction. Further, the grower survey did not indicate any appreciable pre- to post hurricane changes in the proportions of fruit marketed through various market channels. Large shifts could have required significant investments in marketing infrastructure.

The grower survey also provided insights as to the prevailing market structure of the tropical fruit industry in south Florida. For the most part, the industry is typified by growers with small acreages, many of whom are vertically integrated, i.e., they do their own packing and shipping. The most notable exceptions are producers of the avocados, limes and mangos. These three crops are dominated by a few large, integrated grower-packer-shippers that generally do an excellent job of marketing their output. It should be noted that avocados and Persian limes are covered by Federal market orders. It was because of these crops' long history of quality control and successful marketing programs that they were not included in the present study's trade surveys. 
The grower survey also confirmed that none of the selected fruits were marketed through farmers' cooperatives. However, some fruit growers use facilities of an agricultural cooperative to pack and market their own fruit. Prior to the hurricane, a very small quantity of limes was marketed through a processing cooperative in a distant county. Further, there appeared to be little grower interest in a marketing coop; only two percent of those interviewed expressed the need for such an organization. Also, very small proportions of most tropical fruits were found to be marketed directly to consumers despite growers' proximity to one of the state's most populous and ethnically diverse metropolitan areas. For eight of the 11 selected fruits, direct marketing accounted for less than 4 percent of total production.

One objective of the study was to identify areas of the U.S. with the greatest concentrations of Asians and Hispanics in order to devise more efficient marketing programs to reach these ethnic groups. These groups were targeted because south Florida fruit shippers had identified them as being heavy users of tropical fruit. The geographic areas of the U.S. with the greatest numbers of Asians were found to be the populous northeast, industrial cities of the upper midwest, and major urban centers in Texas and the Pacific west coast. Relatively large numbers of Hispanics were found in urban centers of the northeast, upper Midwest and the west coast. Large numbers of Hispanics were also found in Florida and southwestern regions of the U.S., including Texas, Oklahoma, New Mexico, Arizona, and Colorado.

From a marketing standpoint, however, it is not sufficient to locate and target "Asian" and "Hispanics." While ethnic subgroups of each of these large categories share some common values, there are also many significant cultural differences which should be taken into consideration. For example, a promotion built around Cinco de Mayo (Battle of Puebla), a major Mexican holiday, would have little or no significance to Cubans, Dominicans, or most other Hispanic subgroups. Ethnic detail by city, coupled with cultural attributes and religious and secular holidays celebrated by major ethnic subgroups, can help shippers efficiently identify markets and plan timely, effective promotions.

Analyses of census data by prevailing geographic grocery distribution pattern revealed that 30 distribution regions contained both the top 25 Asian and top 25 Hispanic metropolitan statistical areas (MSAs). A telephone survey of the three largest supermarket chains in each of the 30 regions was conducted to determine the general availability, sales success, and retailers' preferred promotional methods for the 11 selected tropical fruits. Usable data were obtained from 75 firms which represented 15,155 stores. Although the 30 grocery distribution regions were initially selected because of their high concentrations of Asian and Hispanic residents, it should be noted that these areas are among the most densely populated in the U.S. In addition to the estimated 7.0 million Asians and 23.7 million Hispanics, these 30 regions also contained 149.0 million white and 22.9 million blacks in 1990. The 30 areas accounted for about 73 percent of the total U.S. population.

Mangos and papayas were available in all chains and all stores, while carambola were carried by 71 of 75 firms representing 97 percent of all stores. Sales performance of these fruits was also rated favorably by most produce buyers. Passion fruit, guavas, specialty bananas, and lychees were available on a regular (or seasonal) basis in about one half to two-thirds of all stores, but sales ratings 
were disappointing; depending on the fruit, about 60 to 80 percent of the respondents rated sales as poor. Atemoyas, mamey sapotes, longans, and sugar apples were typically available in less than onethird of the chainstores. Sales ratings of these fruits were also disappointing, with two-thirds or more of the retailers describing sales as "poor".

Chainstore produce buyers identified four basic impediments to greater sales volume of the 11 targeted fruits. These obstacles were (1) lack of consumer knowledge and awareness, mentioned by 40 to 70 percent of the buyers, (2) relatively high prices, mentioned by 15 to 20 percent, (3) supply problems such as limited or inconsistent supplies and short production seasons, cited by three to 20 percent. Complaints about product quality, the fourth obstacle to greater sales, were minimal for most of the 11 fruits. However, almost every fruit received a few complaints about blemishes and bruises. Specialty bananas received the greatest number of quality complaints, with produce buyers complaining that they frequently arrived bruised or overripe. Most quality comments about mangos had to do with varietal preferences, with most chain buyers expressing a preference for blush varieties because of sales or "eye" appeal. A few buyers expressed a particular dislike for yellow or green-skinned mangos, but several recognized that Asian customers were more likely to have a preference for better tasting yellow or green skinned varieties. One possible strategy would be to differentiate these yellow/green skinned varieties as "Asian mangos" and promote these to the trade as premium quality "Asian mangos". A similar product differentiation has already been achieved with high quality (and usually high-priced) Asian pears.

Retailers' use of various promotional methods for tropical fruit was also explored. About 20 percent of the retailers reportedly used no promotional activities of any type for tropical fruit, other than basic product identification. Not surprisingly, these firms also reported fair or poor sales for all of the 11 selected tropical fruit. The most frequently used, and generally the highest rated promotional methods were newspaper ads, in-store demonstrations, price specials, special displays, recipes, and "tropical theme" promotions involving multiple kinds of fruits.

When asked to evaluate an array of methods and materials for their perceived effectiveness in promoting tropical fruit, price cards, posters, in-store demonstrations, and recipes were recommended by 62, 58 and 57 and 49 percent of the firms, respectively. There was slightly more support for these promotional methods from smaller chains. Preferred sizes for price cards were relatively small, with the most popular size requested 7" x 11". Nearly 90 percent of the retailers using price cards from outside sources wanted formats smaller than 80 square inches. Retailers insist that price cards must "fit" their usual shelf space allocations for various produce items. A large format price card usually will not encourage retailers to allocate greater space to an item; instead, the card will not be used at all. Preferred poster dimensions were also variable, but "standard" sizes such as 20" x 30" and 24" x 36" are generally acceptable. Posters would be most likely incorporated into tropical theme displays where a variety of fruits would be featured. Brochures and ad slicks were recommended by about 21 and 14 percent, respectively, but these tended to be used by larger chains. About one-fourth of the retailers recommended that the Florida tropical fruit industry develop a promotional kit containing a variety of point-of-sale items, similar to those provided by many agricultural commodity groups and packaged dry grocery manufacturers. Such kits usually contain price cards, recipe pads, posters and ad slicks. Several retailers also recommended that 
Florida develop generic tropical fruit promotions that could be used for different types of fruit. Although this approach could extend the useful life of some materials, it could also generate a "free rider" problem if retailers were to use Florida materials to promote fruit from other producing regions or countries.

Retailers also recommended mass media such as television and radio ads, and magazine ads for promoting tropical fruit and educating consumers. However, given the limited funds available to the Florida tropical fruit industry, paid advertising directed at consumers is probably not a viable option. Food publicity methods such as feature stories in newspaper food pages and magazines and also feature appearances by industry representatives on TV cooking shows were also recommended. Several retailers suggested targeting the foodservice industry (restaurants, schools, etc.) as a means of introducing and promoting tropical fruits to consumers.

Several retailers admitted being somewhat unfamiliar with some of the more exotic fruits, and suggested educational efforts directed at the retail trade would be worthwhile. Results of the retailer survey confirmed the unfamiliarity of many buyers with sugar apples, longans, mamey sapotes, atemoyas and lychees. Exhibits at trade shows sponsored by organizations such as the Produce Marketing Association and United Fresh Fruit and Vegetable Association can serve to educate retailers, especially when shows coincide with the availability of fresh fruit. For fruit with very short seasonal availability, it might be more productive to cultivate positive contacts with retailers by providing them with sample packs of selected fruits along with availability and handling information, and POS materials.

Survey data from 145 specialty produce wholesalers throughout the U.S. showed widespread, almost universal availability of mangos and papayas. Carambolas were available from about 60 percent of the wholesalers east of the Mississippi River, but just under 40 percent in the western region. Lychees, guavas and passion fruit were available from nearly half of the wholesalers in the eastern region, but availability was considerably lower in the west. Similarly, mamey sapotes, atemoyas, longans and sugar apples were handled by 23,21, 15 and 10 percent of the eastern region firms, respectively; in the west, availability was only about one-fourth to half as great.

The limited availability of many of the exotic tropical fruits in western states is undoubtedly caused by phytosanitary restrictions designed to keep the Carribean fruit fly out of Texas, Arizona and California. For some fruits, phytosanitary restrictions require a total ban; others require extended cold treatment or hot water treatment which can adversely affect quality. Specialtybananas from Florida are not affected by these phytosanitary restrictions because bananas are not a host to the Carribean fruit fly. However, competition from Mexico, Central America and South America will more than likely preclude Florida from capturing significantly larger market share in distant western and eastern U.S. markets.

Specialty produce wholesalers generally reported positive sales trends for the previous two year period. For nine of the 11 selected fruits, more than 90 percent of the wholesalers reported either stable or increasing sales trends. For the two remaining fruits, over 85 percent noted stable 
or increasing sales. For every one of the 11 fruits, the percentages of wholesalers reporting upward trends in sales were considerably greater than those reporting declining sales.

Produce wholesalers also provided insights for improving sales of each of the 11 selected tropical fruits. Increased promotion was the most frequently mentioned market development strategy for eight of the 11 tropical fruits, but improved quality was cited most frequently for mangos and passion fruit. Increased promotion and improved quality were recommended by equal numbers of wholesalers as preferred means of increasing sales of Florida-grown papayas. Overcoming supply problems such as erratic availability and short seasonal availability were also mentioned as viable options for many of the fruits, but particularly for lychees and longans. For most of the 11 fruits, significant numbers of wholesalers also suggested that lower prices would stimulate increased consumer awareness and consumption, and some suggested that tropical fruits were less than a good value for consumers when compared to many other types of fruit. While a "lower price" strategy appears logical and would most likely stimulate consumer trial and greater consumption, current prices reflect prevailing supply and demand conditions. It would be poor business management on the part of Florida growers and shippers to accept lower prices than what the market will bear when there is no assurance that price reductions will be passed on to retail customers. One strategy to develop an improved value image in the trade would be for the Florida tropical fruit industry to anticipate and monitor periods of heavy supplies, which are likely to result in lower prices. Peak supply periods could be publicized to the trade, possibly resulting in retail features along with price specials that would encourage consumers to try the fruits while maintaining F.O.B. prices at acceptable levels for growers and shippers. 


\section{CONCLUSIONS AND RECOMMENDATIONS}

This study of the tropical fruit industry in south Florida and the marketing system for tropical fruits throughout the U.S. indicates there is much potential for Florida's tropical fruit growers and shippers. Although distribution of mangos, papayas and carambolas is practically universal throughout the U.S., the surveys of specialty produce wholesalers and major food retailers revealed limited distribution and availability for most of the other tropical fruits. Making these lesser-known fruits more widely available to wholesalers, retailers and ultimately consumers will do much to improve total sales and strengthen the south Florida tropical fruit industry.

Wholesalers and retailers that are not currently handling these tropical fruits produced in south Florida will have to be convinced that it is in their best competitive interests to do so, and those that are handling them must be encouraged to improve their marketing efforts. These are the biggest challenges to Florida's tropical fruit growers and shippers. A recent survey of produce buyers of major supermarket chains in the U.S. conducted by researchers at Cornell University revealed that supply availability, profit potential, nutritional information, vendor support, ripeness information, preparation and recipe information were important factors in deciding whether or not to carry a new produce item. Other factors which influenced their decision to carry or not carry an item included residue-free evidence, test marketing results and availability of point of sale material. Further, chain produce buyers participating in the Cornell study felt that the burden of providing marketing and promotional information for new produce items rested on suppliers (51 percent), commodity organizations ( 28 percent) and national trade organizations ( 7 percent). Only 12 percent felt retailers were primarily responsible for providing their customers with such information (McLaughlin and Perosio, 1994).

Our survey of specialty wholesalers also found that relatively few developed any type of educational or promotional materials for tropical fruit in-house. Thus, it is obvious that south Florida growers and shippers will have to develop and provide educational information and promotional materials largely at their own expense if they engage in serious market expansion efforts. Development of the brochure "Tastes of The Tropics," the video tape "Tropical Fruit," and the tropical fruit section of the Florida Department of Agriculture and Consumer Services (FDACS) web page represent excellent progress in providing the trade and consumers with information about tropical fruits, but more is needed. While a few Florida tropical fruit shippers may be large enough to justify the costs of developing effective marketing information and implementing large-scale market development programs, our grower-shipper survey indicates that most shippers' volumes are too limited to adequately support such programs and reap the benefits of such programs, particularly for individual species of fruit.

\section{$\underline{\text { Specific Recommendations }}$}

With the exception of the first two major sections, the recommendations below are not prioritized; they appear in no particular order of importance. The recommendations begin with "product quality and availability", because having a quality product to sell is the cornerstone of success. A not-too-distant second place section addresses the need for "organized marketing" in the 
south Florida tropical fruit industry. Indeed, if it could be successfully argued that nothing but top quality fruit is currently being shipped, organized marketing would certainly be the top-ranked strategy to achieve marketing goals.

\section{Product Quality and Availability}

In any business endeavor, the "product" is the basis for success or failure. No amount of promotion can make a long-term success out of an inferior product. In the words of Bill Bernbach, a noted advertising executive, "A great ad campaign will make a bad product fail faster. It will get more people to know it's bad.....it's the product itself that's all important....." (Jones, 1986). Lewis Kornfeld, Radio Shack's "Master Marketer", formulated 129 rules of marketing in his book To Catch A Mouse, Make a Noise Like a Cheese. His "First Rule of Marketing" is "without a product, you don't have a business, the formula is $0 \times 1=0$ " (Kornfeld, 1992). Although this study's surveys of the produce trade revealed relatively few complaints about product quality, practically every type of fruit received some. The most frequent complaints were about erratic supplies or short production seasons. Obviously, some supply problems cited by the trade are difficult to solve because of natural forces and the biological cycles of the fruit. Lychees, longans, atemoyas, and sugar apples are particularly and adversely affected by short marketing seasons, ranging from a few weeks to several months. Only specialty bananas and papayas have year-round availability in south Florida. New cultivars, cultural practices, or storage technology should be developed in order to extend the availability of higher quality fruit in the marketplace.

Other fruits, particularly papayas and mangos, received complaints about varietal characteristics. All of the fruits could possibly benefit from improved cultivars, but even excellent cultivars cannot overcome quality problems caused by suboptimum harvest or rough handling. In addition to harvesting and packing for optimum quality, fruit quality and retailer acceptance can also be improved by paying greater attention to packaging and labeling. Alternative packaging materials such a corrugated master containers or flats containing clear plastic clamshell or tub packages may extend shelf life, prevent fruit damage and add value to retailers. Such packages can showcase the fruit and also provide a surface to put information stickers, i.e., stickers with brands, uses, ripening instructions nutritional origin, etc. UPCs (uniform product codes) or PLU (product look up) numbers should be used on retail packs or on individual fruit as appropriate. A leading marketer of specialty produce utilizes PLU stickers and labels which include country of origin, a brief product description, storage and serving information, nutrition facts, a free recipe offer, a consumer guarantee, an "800" number and an e-mail address; another includes short recipes on containers (Carder, 1994). Stickers with selling words such as "Fresh", "Tropical", etc. can also be used to attract attention and help sell customers. Well-designed PLU stickers can also provide much information, but care should be used to make sure the design is not cluttered and that the PLU number is large enough for retail checkout clerks to read. 


\section{Organized Marketing}

Because of the relatively large numbers of small-scale grower-shippers marketing the tropical fruits examined by this study, it is recommended that growers and shippers that have insufficient volume to afford or justify branded product marketing programs on their own consider combining forces with other growers and shippers in joint or "organized" marketing activities. There are numerous kinds of legal organized marketing arrangements, ranging from informal partnerships to highly structured and regulated marketing orders and cooperatives. While joining forces with other growers and shippers can facilitate more aggressive and effective market development programs by sharing costs, the biggest advantages can be greater efficiency and a consolidation of market power. By controlling a larger proportion of available supplies, and reducing the number of small competitors, large private firms or cooperatives may become more efficient in packing and shipping and can sometimes avoid unnecessary and damaging price competition. Additionally, joining forces with other growers and shippers can also establish and enforce quality standards that can provide the trade and consumers with assurance of a consistently high quality product. High quality is especially critical where consumers have little or no experience with a product; a first-time purchaser of an inferior quality tropical fruit is very unlikely to become a repeat purchaser. Further, organized marketing can also provide buyers with larger or more regular supplies, avoiding the frustration of erratic or limited availability. Finally, large marketing organizations have more leverage in market disputes (Abel, Daft, Earley \& Ward, International, 1995). Several of the most common forms of organized marketing are discussed below.

\section{Contracts with existing firms}

One approach is to develop positive working relationships with larger, successful shippers that have ongoing market development programs in place. Contracting sales of fruit to such firms and agreeing to provisions for specific promotional activities may prove to be mutually beneficial.

\section{Marketing orders}

If production volume is sufficient, consider state or federal marketing orders. Such orders typically establish quality and packaging standards and allow for assessments that can be used for research and market development programs. Because virtually all shipments out of a prescribed production area are subject to assessments, everyone pays a fair share for programs. The "free-rider" problem can be significantly reduced, if not eliminated. However, where production is relatively small (as for individual species of limited acreage) administrative costs can be prohibitively large, leaving little revenue for research and promotion. Even if administrative costs are reduced by "piggy-backing" onto an existing marketing order, revenues might still be insufficient to implement aggressive market development programs for some of the fruit crops with limited volume. 


\section{Marketing cooperatives}

Farmers' marketing cooperatives can sometimes provide benefits by increasing numbers' marketing power. A cooperative may also establish more consistent packaging and quality standards, more consistent supplies, and more efficient transportation to market by aggregating small shipments into full containers or by mixing loads if necessary. Marketing cooperatives can also engage in market development activities that would be beyond the financial reach of individual growers or small shippers. However, as with any type of voluntary organization, non-participating growers and shippers can obtain a "free ride" from these activities. Additionally, organizing and maintaining an efficient marketing cooperative can be a challenge. In order to be successful, a marketing coop must have sufficient sales volume to operate efficiently. This requires not only sufficient start up volume, but continued commitment by growers to market their production through the cooperative, even when prices might be better elsewhere. Growers must also feel that they are being treated fairly with respect to quality discounts or penalties and expenditures on market development activities for their specific crops. Further, finding competent, dedicated management and administrative personnel can be difficult, especially with limited, start-up operating budgets.

\section{$\underline{\text { Voluntary associations }}$}

Voluntary trade associations can be an effective way to educate the general public, as well as local and state decision makers about the tropical fruit industry. Association activities can also gain visibility for specific types of fruit crops. Organizations such as Tropical Fruit Growers of South Florida, Inc. can generate much publicity (unpaid media coverage) by sponsoring or participating in community activities such as fairs, festivals and legislative appreciation events. Sponsoring recipe contests, "largest fruit" contests, or other fun events can attract considerable media attention. Recipe contests can also help build an invaluable recipe database that can be used in consumer-oriented promotional programs. Grower/shipper organizations can also develop volunteer programs to sponsor and conduct local in-store demonstrations and educational programs in schools and 4-H clubs. Other association sponsored activities might include preparation of news releases which include recipes and photographs. These can be distributed to food page editors of newspapers within a targeted market area. The association might also screen and sponsor volunteers to appear on television cooking shows to promote the use of selected tropical fruits.

Membership and participation in state and national trade associations is also a way to gain visibility for the tropical fruit industry and to disseminate factual information about tropical fruits to the produce trade. Key organizations include the Florida Fruit and Vegetable Association, The United Fresh Fruit and Vegetable Association, and The Produce Marketing Association. These organizations publish newsletters and other materials that help to educate the trade. Further, the national associations host annual trade shows which can be a viable way of reaching the produce trade with information about Florida grown tropical fruit and potential suppliers.

Finally, voluntary associations such as Tropical Fruit Growers of South Florida, Inc. can maintain strong working relationships with organizations such as the Florida Department of Agriculture and Consumer Services (FDACS) and the University of Florida. Many state 
Departments of Agriculture have implemented promotional programs for food items, especially produce, grown in their respective states. "Jersey Fresh," "Taste of Texas," "Arizona Grown," and "Ohio Proud" are examples of such programs. However, few other states' generic promotional programs can compare with FDACS' successful "Fresh from Florida" campaign. The Department has a long-standing tradition of providing marketing assistance to Florida's commodity groups. FDACS, in cooperation with Tropical Fruit Growers of South Florida, Inc. and the Tropical Fruit Advisory Council, has provided invaluable marketing assistance in recent years by developing the "Tastes of the Tropics" brochure, a tropical fruit video, and a presence on the FDACS web page on the internet. The University of Florida also has a long history of providing the south Florida agricultural community with technical production research and marketing research as well. Continuing these close working relationships can greatly multiply tropical fruit growers' and shippers' production and marketing efforts.

\section{Market Development: Geographic Considerations}

Supplies of many of the fruits studied appear to be too limited to adequately meet the needs of a major, nationwide promotional program, even if resources were available to fund such an effort. Because of limited supplies, phytosanitary restrictions in several states where large numbers of ethnic populations reside and relatively short shelf life for some, it is recommended that modest market development efforts initially focus on south Florida, expand to ethnic markets where phytosanitary restrictions pose fewest problems, and then grow into mainstream markets closest to Florida, primarily the eastern seaboard. Obviously, this strategy could be altered to accommodate promotional programs in other geographic areas deemed ripe for market development because of wholesaler or retailer interest and cooperation. Selling to local wholesalers, retailers and foodservice firms has many potential advantages. These include lower transportation costs (which may result in more competitive retail prices), better product quality and greater shelf-life. Also south Florida markets contain some of the largest concentrations of Asian and Hispanic consumers in the U.S., many of whom are already familiar with tropical fruits. Further, the annual influx of affluent winter visitors and a steady inflow of tourists provide a market eager to try the local fare which they may view as "new" and exotic. Many longer-term winter visitors can be reached through supermarkets and produce stores, but upscale foodservice outlets have the potential of reaching a much broader cross-section of visitors. Rather than pursuing individual foodservice outlets, it would probably be more efficient to work through foodservice suppliers or jobbers specializing in produce sales to upscale restaurants. Targeting local retail and foodservice markets can increase tropical fruit sales in the short term, and also have positive long-term effects as well. Exposing visitors to these fruits can help to disseminate knowledge of them to distant geographic markets, increasing consumer demand in other areas. Another strategy is to target specialty produce wholesalers and retailers in areas of the U.S. with large numbers of Asians and Hispanics. Most of the eleven fruits examined by this study are grown in tropical regions throughout the world and are generally well-known by Asian and Hispanic populations. Because of their familiarity with these fruits, promotional efforts can focus on making these consumers aware of the fruits' availability, rather than expensive educational efforts directed at shoppers that are totally unfamiliar with the fruit. Point-of-sale materials such as price cards and posters written in appropriate Spanish or Asian languages should be developed for these niche cultural and geographic markets. Finally, as fruit supplies and 
promotional resources permit, markets east of the Mississippi River should be targeted because of fruit quality problems caused by fruit fly control measures and quarantines imposed by states with phytosanitary restrictions on some fruit. Additionally, markets closer to Florida can reduce fruit damage in transit and quicker delivery can effectively extend shelf life of fragile fruit.

\section{Development Activities for Traditional Commercial Markets}

The following market development activities are recommended without regard to how they are to be financed, i.e., by large or small private firms or by organized cooperators. Some are obviously beyond the financial reach of small firms, but others can be utilized by virtually any participant in the south Florida tropical fruit industry.

\section{Educational programs and materials directed to the produce trade}

Many produce buyers of wholesale and retail firms could benefit by knowing more about the tropical fruits included in this study. Although most were familiar with mangos, papayas and carambolas, there was evidence that buyers' knowledge of some fruits was limited. Increasing buyers' familiarity with Florida's tropical fruit will get product into more stores and provide exposure to more consumers. The activities below are recommended to reach wholesale and retail produce buyers and merchandisers.

Trade shows.--Participation in industry trade shows is a great way to reach top echelon produce executives. Sponsoring a booth at national shows (Produce Marketing Association or United Fresh Fruit \& Vegetable Association) may be out of the question because of the expense, but cooperating with other Florida commodity groups might be feasible.

Product samples.--Provide potential buyers with product samples if possible. "How does it eat?" is a common question in the produce business; eating is believing, and a great way to educate. Provide samples at trade shows to reach produce retailers and wholesalers. Targeted samples delivered directly to key buyers have been used to good advantage by successful specialty produce wholesalers (Carder, 1994). Samples can be delivered via courier or sales/promotion representatives.

Fruit availability calendars.--Easy-to-read fruit availability calendars remind buyers of fruits' seasonal availability. If printed on high quality stock in four colors with photos of the fruit, this type of item will frequently be posted in buyers' offices or warehouses, and can be relatively long-lived. Fruit availability calendars can also be published as part of paid advertising in trade publications, funds permitting.

Handling information.--Handling specifications, i.e., recommended storage temperatures, humidities, packaging, and realistic estimates of shelf life are essential, even to trade professionals. Many are not fully aware of the handling requirements of exotic tropical fruits. 
Tie-ins.--Tie-ins or cross-merchandising ideas can stimulate impulse sales and improve profitability for retailers. Tie-ins can also help educate consumers as to additional uses for tropical fruits.

Consumer information.--Provide buyers with information that consumers expect, such as ripening techniques, typical uses, preparation methods and recipes. These materials may be in the form of ready-to-use point-of-sale materials that can be distributed to consumers, or included in concise instructions to produce handlers which stress "what your customers need to know about [specific type of fruit]." These materials can enhance retailers' images with consumers by making retail sales staff more knowledgeable.

Display contests.--Encourage retailers to promote tropical fruit by sponsoring display contests with prizes and recognition for winners. This approach requires significant expenditures for administration and prizes.

Paid advertising.--Place informational ads in leading trade journals such as The Packer, The Produce News, Progressive Grocer and others. Advertising can make potential buyers aware of fruit availability and identities of shippers and their sales staff.

Trade directories.--As a shipper, make your presence known by getting listed in trade directories such as The Blue Book and The Red Book, and membership directories of organizations such as the United Fresh Fruit and Vegetable Association and the Produce Marketing Association. Because of the growing importance of the internet, getting listed on key websites will help buyers locate you as well.

Direct mail, fax or e-mail.--Remind past customers of seasonal availability of fruit by direct mail, fax or e-mail. Alert them to the beginning of the season and to impending peak supply periods. Most chainstores need at least two or three weeks notice to include items in their merchandising plans. Avoid use of faxes to firms that are not regular customers; many business people resent unsolicited faxes that tie up their machines and increase their operating costs. The same is true for e-mail. The practice of sending unsolicited e-mail, commonly called "spamming", is an aggravation for many people. If e-mail is used, the potential customer should be given the opportunity to be taken off the e-mail distribution list at once, or the e-mail communication may do more harm than good to the sender's reputation and goodwill.

Promotional kit.--Develop a comprehensive retail promotional kit containing commonly used materials such as price cards, shelf talkers, recipes, nutritional brochures, posters, ad slicks, etc. Be sure to specify "Florida" on all materials.

Video tapes.--Provide wholesalers and retailers with training videos that incorporate basic product information and merchandising suggestions described above. 


\section{Educational programs and promotional materials directed to consumers}

There are many kinds of materials that can be used at retail stores and other venues to educate consumers and stimulate sales. In retail stores, a combination of materials and methods often works best. The following are recommended if resources are available.

In-store demonstrations.--In-store demos are particularly effective in setting customers to try and buy new food products. Customers receive product samples and usually get verbal and written information about the product as well. In-store demonstrations are very effective, but also quite costly. Costs may be reduced by utilizing volunteers, especially in key Florida markets.

Point-of-sale materials.--Price cards, posters, die-cuts, brochures, recipes, and video tapes are effective ways to get retailers' and consumers' attention. High quality materials (good stock, fullcolor) items are most likely to get used by retailers. Price cards should be 7" x 11" or smaller. Poster size is not critical, with typical sizes up to 24" x 36". Posters are likely to be used in multiproduct tropical fruit displays. Multiple die-cuts are frequently used in creating larger displays. Bifold or tri-fold brochures can convey lots of information, but making them available to customers can be problematic unless display racks are also provided. Informational brochures are sometimes developed in-house by wholesalers and retailers; such firms welcome factual information. Recipes, on standard 3" x 5" stock and in pads, are usually welcomed by retailers. In addition to recipes, cards can contain information on ripening, storage, general preparation, and nutritional composition. Videotapes should contain much of the same information as brochures and recipe cards. However, recipes, should be left to a printed format in the interest of brevity and convenience unless they are extremely simple.

A tropical fruit web site.--The Internet or "world wide web" is a rapidly growing communication medium. The proliferation of personal computers in offices and homes makes this an effective way to communicate with consumers, many of them highly educated and affluent. A "home page" can be established for as little as \$100. Monthly server fees and maintenance costs for a modest site average about $\$ 100$, but these fees depend on the complexity of the home page design and the number of "hits" (site visitors). A web site could contain color photographs of tropical fruits, basic information on sources (individual Florida shippers), availability, storage, preparation methods and recipes. Visitors can also place orders for fruit or request additional information, depending on the design of the site.

\section{Direct Marketing: An alternative to the traditional commercial market}

Although this study focused on ways to improve marketing of tropical fruit through prevailing, traditional wholesale-retail distribution channels, direct-to-consumer marketing may prove profitable, especially for smaller growers and shippers. Several possibilities are:

Gift fruit marketing.--Shipping fancy gift packs directly to consumers has long been used by fruit growers throughout the U.S. as a profitable means of marketing their fruit. In Florida, many citrus growers have used direct sales as an effective marketing tool; today, approximately 140 
Florida firms are members of the Florida Gift Fruit Shippers' Association, an Orlando-based trade group. This organization assists members in aggregating small shipments for more efficient delivery to distant markets and also helps shippers forge mutually beneficial links with suppliers of processed food items such as jams, jellies, nuts, confections and smoked meat products. Such items are frequently used to complement fresh fruit gift packs by providing customers with a wider variety of merchandise.

In lieu of starting a new gift fruit business, tropical fruit growers might consider cooperating with existing gift fruit shippers. Tropical fruit could also be used to complement gift packs. Although there are not many tropical fruits available during the peak gift fruit season (only carambola, papayas, bananas and passion fruit during November and December), other fruits could be incorporated into "fruit-of-the-month" shipments that are utilized by gift fruit shippers.

Traditionally, gift fruit sales have been promoted by direct mail comprised of brochures and catalogues. However, gift fruit shippers have discovered the internet. Even small firms have developed low-cost but effective websites utilizing tantalizing, full color photos. Websites are versatile; they can be used to quickly reflect product availability and to facilitate immediate e-mail or telephone orders.

Direct marketing via "greenmarkets" or farmers markets.--The Coral Gables Farmers Market, operating seasonally from the fall through late spring, offers an opportunity for smaller-scale Dade County growers to market their production locally. However, given the larger ethnic populations of Dade County (about one million Hispanic residents and 30,000 Asians) plus large numbers of affluent winter visitors, additional "greenmarkets" could move more produce at retail prices. Palm Beach County has established a GreenMarket project through their Agricultural Economic Development Program. This project sponsored by the Palm Beach County Board of County Commissioners assisted by the county extension service. Initially, two GreenMarkets were established in 1995, three were operational in 1996 and seven are planned for 1997. Public patronage has been excellent.

A similar program with one or more outlets located closer to Homestead agricultural production areas could have considerable "entertainment" and shopping appeal, especially to visitors from South Dade suburbs. Locations near the outlet mall at the southernmost end of the Florida Turnpike or the downtown historic district could also have a synergistic affect, attracting visitors for a broader range of shopping experiences. 


\section{Concluding Observations: Opportunities and Challenges}

Just over a hundred years ago, the banana was a novelty item in the U.S. Today, bananas are the most popular fresh fruit in American diets. Americans ate 7.2 billion pounds of bananas in 1995, over 27 pounds per capita. There are a number of other, more recent "success" stories for exotic fruit as well. Twenty years ago, kiwifruit was practically unknown in the U.S., but by 1995 per capita consumption was more than twice that of cherries. Mango consumption increased 10-fold between 1974 and 1995, and papaya consumption quadrupled during this period.

Some of the increases in consumption of these and other fresh fruits have come at the expense of citrus fruits, particularly oranges, grapefruit, and canned fruits. While there have been some "winners" and some "losers" in the battle for consumers' favor, consumption of total fresh fruit has increased dramatically over the past several decades. In the early 1970s, annual per capita fresh fruit consumption ranged from about 91 to 96 pounds, but by the mid-1990s, consumption exceeded 120 pounds. Some of these increases in fresh fruit consumption can be attributed to cheaper imports, improvements in transportation, storage and distribution, and to increased availability of many fruits on a year-round basis due to contra-seasonal imports. However, increased consumer awareness of health benefits associated with fresh produce, consumers' greater purchasing power, growth in ethnic populations, and consumers' willingness to try new, exotic items have also fueled increases in fresh fruit consumption.

Most of the factors that have boosted consumer demand for fresh fruits, with the exception of lower cost competing imports, bode well for the tropical fruit industry of south Florida. While the odds of discovering another "banana" are small, opportunities abound for many of the eleven fruits targeted by this study. The overall business climate for "new" or unusual tropical fruit is very positive. The challenge for the south Florida tropical fruit industry is to develop coordinated, affordable and aggressive market development programs that will foster expanded and profitable production. 


\section{LITERATURE CITED}

Abel, Daft, Earley \& Ward International. A Market Study for Exporting Hawaii's Tropical and Specialty Fruits to Canada. Alexandria, VA, 1995.

American Management Association. Successful Marketing to U.S. Hispanics and Asians. AMA Membership Publications Division, New York, NY, 1987.

Arizona Department of Agriculture, Plant Services Division. Summaries of Extension Quarantines. May 8, 1995.

Bennett, Stephen. 1995 Produce Annual Report: The Profit Powerhouse. Progressive Grocer, Vol. 74, No. 10, October 1995.

California Department of Agriculture. California Plant Quarantine Manual, December 12, 1996.

Campbell, Richard J., (Ed.). A Guide to Mangos in Florida. Fairchild Tropical Garden. Miami, FL, 1992.

Carder, Doug. "Specialty Produce: Two Firms Rise to the Top". The Packer, Vol. CI, No. 30, July 25, 1994.

Degner, Robert L., Stephenie K. Mack and Susan D. Moss. Dade County Agricultural Acreage Estimates, Pre- and Post Hurricane Andrew. Staff Report 95-1, FL Agr. Market Res. Center. 1995.

Florida Agricultural Statistics Service. Tropical Fruit Acreage, Production and Value. April 1993.

Florida Department of Agriculture and Consumer Services. "Tastes of the Tropics." Tallahassee, FL. 1993.

Forker, Olan D., and Ronald W. Ward. Commodity Advertising: The Economics and Measurement of Generic Programs. Lexington Books (McMillan, Inc.), New York, 1993.

Galceran, I., and J. Berry. "A New World of Consumers." American Demographics. Volume 17, Number 3, March 1995.

Hornby, Paul. Florida Department of Agriculture and Consumer Services, Division of Plant Inspection. Gainesville, Florida. Personal communication, February 5, 1997.

Jones, John Phillip. What's in a Name?: Advertising and the Concept of Brands. Lexington Books (D.C. Heath and Co.). Lexington, MA., 1986. 
Kornfield, Lewis. To Catch A Mouse Make A Noise Like A Cheese. The Summit Group, Fort Worth, TX, 1992.

Mazak, L. M. and R. L. Degner. Market Development Strategies for Selected Tropical Fruits. Proc. Fla. State Hort. Soc. 107:319-322. 1994.

McLaughlin, Edward W., and Debra J. Perosio. Fresh Fruit and Vegetable Procurement Dynamics: The role of the Supermarket Buyer. R.B. 94-1, Department of Agricultural, Resource and Managerial Economics, College of Agriculture and Life Sciences, Cornell University, Ithaca, New York, February, 1994.

Miranda, G. E. "In the Hispanic Marketplace, Think Family, Think '50s." DM News Volume 18, Number 5, February 5, 1996.

Pomerantz, Michele Logan, Ed. Fresh Trends 1995. The Packer, Vol. CI, No. 54.

Produce Reporter Company. The Blue Book. Carol Stream, IL. 1995.

Progressive Grocer. 1994 Marketing Guidebook. Trade Dimensions. Stamford, CT. 1993.

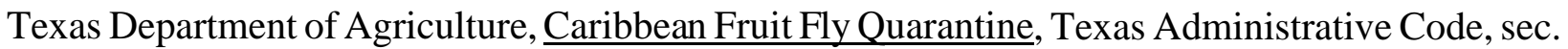
5.121-5.125, Texas Secretary of State, 1996.

Tong, Jennie. "Allocating Budgets to Ethnic Media: How Research Can Maximize Return on Investment." Asian, Black and Hispanic Research: Pointing the Way to Marketing Effectiveness Transcript Proceedings of the ARF Third Annual Media Research Workshop. Advertising Research Foundation, New York, NY, 1991.

U.S. Department of Commerce, Bureau of the Census, Population Division. Census of Population, Release PPL-41, 1990.

Wong, Angi Ma. Target: The U.S. Asian Market. Pacific Heritage Books, Palos Verdes, CA, 1993. 


\section{Appendix to:}

\section{Market Development Strategies for the Florida Tropical Fruit Industry}

Florida Agricultural Market Research Center Industry Report 97-2

December 1997

by

Robert L. Degner

Susan D. Moss

Jonathan H. Crane

Submitted to the Florida Department of Agriculture and Consumer Services

by the Florida Agricultural Market Research Center

Food and Resource Economics Department

Institute of Food and Agricultural Sciences

University of Florida, Gainesville, FL 32611 
Appendix Table A-1. Estimates of pre-hurricane sales distributions for selected tropical fruits, Dade County, Florida, in percentages.

\begin{tabular}{|c|c|c|c|c|c|c|c|}
\hline \multirow[b]{2}{*}{ Fruit Crop } & \multicolumn{7}{|c|}{ Distribution of Sales Volume } \\
\hline & $\begin{array}{l}\text { Not } \\
\text { sold } \\
\end{array}$ & $\begin{array}{l}\text { Sold directly } \\
\text { to consumers }\end{array}$ & $\begin{array}{c}\text { Sold on-tree } \\
\text { to local dealers }\end{array}$ & $\begin{array}{c}\text { Sold to local } \\
\text { packer/shippers }\end{array}$ & $\begin{array}{l}\text { Self packed } \\
\text { and shipped }\end{array}$ & $\begin{array}{l}\text { Sold through } \\
\text { coops }\end{array}$ & $\begin{array}{c}\text { Total estimated } \\
\text { distribution }\end{array}$ \\
\hline & $(-\cdots$ & & -1 & -percent - & 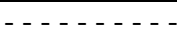 & & - - - - - \\
\hline Avocado & 0.1 & 0.1 & 0.2 & 42.2 & 57.5 & 0.0 & 100.0 \\
\hline Tahiti lime & 0.1 & 0.0 & 0.0 & 50.5 & 49.1 & 0.3 & 100.0 \\
\hline Mango & 0.1 & 3.4 & 3.8 & $\mathbf{5 7 . 9}$ & 34.8 & 0.0 & 100.0 \\
\hline Carambola & 1.7 & 0.1 & 0.8 & 53.1 & 44.3 & $\mathbf{0 . 0}$ & 100.0 \\
\hline Lychee & 4.4 & 6.4 & 2.6 & 31.3 & 55.4 & 0.0 & 100.0 \\
\hline Papaya & $\mathbf{0 . 0}$ & 0.1 & 5.2 & 17.4 & 77.3 & 0.0 & 100.0 \\
\hline Mamey sapote & 0.1 & 0.1 & 44.5 & 6.6 & 48.7 & $\mathbf{0 . 0}$ & 100.0 \\
\hline Banana/plantain & 3.0 & 14.1 & 12.8 & 30.4 & 39.7 & 0.0 & 100.0 \\
\hline Longan & 2.3 & 0.9 & 6.3 & 36.9 & 53.6 & 0.0 & 100.0 \\
\hline Guava & $\mathbf{0 . 0}$ & 2.8 & 1.4 & 0.2 & 95.7 & 0.0 & 100.0 \\
\hline Barbados cherry (Acerola) & 50.0 & 0.0 & 0.0 & 0.0 & $a$ & $a$ & 50.0 \\
\hline Passion fruit & 0.2 & 0.2 & 0.0 & 23.0 & 76.6 & 0.0 & 100.0 \\
\hline Atemoya & 0.2 & 0.1 & 0.1 & 7.7 & 91.9 & $\mathbf{0 . 0}$ & 100.0 \\
\hline Pummelo & 0.2 & 0.1 & 8.0 & 84.6 & 7.1 & 0.0 & 100.0 \\
\hline Jackfruit & 0.0 & 1.0 & 0.0 & 11.7 & 87.2 & 0.0 & 100.0 \\
\hline Kumquat & 1.7 & 1.0 & 0.0 & 47.1 & 50.2 & 0.0 & 100.0 \\
\hline Citrus (misc.) & 0.8 & 0.0 & 0.0 & 0.0 & $a$ & $a$ & 0.8 \\
\hline Sugar apple & 0.4 & 12.8 & 19.5 & 36.7 & 30.6 & 0.0 & 100.0 \\
\hline Key lime & 0.5 & 0.4 & 0.0 & $a$ & $a$ & $a$ & 1.0 \\
\hline Sapodilla & 0.0 & 15.3 & 74.9 & $a$ & $a$ & $a$ & 90.2 \\
\hline
\end{tabular}

Not reported because of confidentiality restrictions.

Source: Survey data, Florida Agricultural Market Research Center, University of Florida, 1995. 
Appendix Table A-2. Estimates of post-hurricane sales distributions for selected tropical fruits, Dade County, Florida, in percentages

\begin{tabular}{|c|c|c|c|c|c|c|c|}
\hline \multirow[b]{2}{*}{ Fruit Crop } & \multicolumn{7}{|c|}{ Distribution of Sales Volume } \\
\hline & $\begin{array}{l}\text { Not } \\
\text { sold }\end{array}$ & $\begin{array}{l}\text { Sold directly } \\
\text { to consumers }\end{array}$ & $\begin{array}{c}\text { Sold on-tree } \\
\text { to local dealers }\end{array}$ & $\begin{array}{c}\text { Sold to local } \\
\text { packer/shippers }\end{array}$ & $\begin{array}{l}\text { Self packed } \\
\text { and shipped }\end{array}$ & $\begin{array}{l}\text { Sold through } \\
\text { coops }\end{array}$ & $\begin{array}{c}\text { Total } \\
\text { distribution } \\
\end{array}$ \\
\hline & $-\cdots$ & $\ldots \ldots$ & - - - - - - & - - - -percent - - - & - - - - - & - - - - - & ------) \\
\hline Avocado & 0.0 & 0.0 & 0.2 & 43.0 & 56.7 & 0.0 & 100.0 \\
\hline Tahiti lime & 0.2 & 0.0 & 0.0 & 60.4 & 39.4 & 0.0 & 100.0 \\
\hline Mango & 0.1 & 3.9 & 4.4 & 45.3 & 46.3 & $\mathbf{0 . 0}$ & 100.0 \\
\hline Carambola & 1.2 & $\mathbf{0 . 0}$ & 1.7 & 54.0 & 43.0 & $\mathbf{0 . 0}$ & 100.0 \\
\hline Lychee & 1.0 & 7.0 & 7.6 & 44.9 & 39.6 & 0.0 & 100.0 \\
\hline Papaya & 0.1 & 0.1 & 0.0 & 34.1 & 65.7 & 0.0 & 100.0 \\
\hline Mamey sapote & 0.1 & 0.4 & 47.3 & 5.4 & 46.8 & 0.0 & 100.0 \\
\hline Banana/plantain & 1.4 & 4.7 & 3.9 & 36.8 & 53.3 & 0.0 & 100.0 \\
\hline Longan & 0.6 & 1.9 & 13.2 & 32.4 & 51.9 & 0.0 & 100.0 \\
\hline Guava & 0.0 & 2.1 & 1.0 & 0.4 & 96.5 & 0.0 & 100.0 \\
\hline $\begin{array}{l}\text { Barbados cherry } \\
\text { (Acerola) }\end{array}$ & 66.6 & 0.0 & 0.0 & $a$ & $a$ & $a$ & 66.6 \\
\hline Passion fruit & 0.5 & 0.0 & 0.1 & 10.0 & 89.4 & 0.0 & 100.0 \\
\hline Atemoya & 0.0 & 0.0 & 0.2 & 3.7 & 96.1 & 0.0 & 100.0 \\
\hline Pummelo & 0.1 & 24.6 & 1.4 & 52.4 & 21.4 & 0.0 & 100.0 \\
\hline Jackfruit & 0.7 & 0.0 & 13.6 & 14.8 & 70.9 & 0.0 & 100.0 \\
\hline Kumquat & 0.8 & 1.2 & 0.0 & 32.3 & 65.6 & 0.0 & 100.0 \\
\hline Citrus (misc.) & 0.3 & 0.0 & 0.0 & $a$ & $a$ & $a$ & 0.3 \\
\hline Sugar apple & 0.8 & 4.7 & 34.3 & 19.6 & 40.6 & 0.0 & 100.0 \\
\hline Key lime & 0.1 & 0.2 & 27.7 & $a$ & $a$ & $a$ & 28.0 \\
\hline Sapodilla & 0.8 & 20.2 & 64.9 & $a$ & $a$ & $a$ & 85.8 \\
\hline Coconut palm & 83.3 & 0.0 & 0.6 & $a$ & $a$ & $a$ & 83.9 \\
\hline Wax jambu & 0.9 & 0.0 & 0.7 & 20.3 & 78.1 & 0.0 & 100.0 \\
\hline Persimmon & 0.0 & 0.0 & 32.9 & 67.1 & 0.0 & 0.0 & 100.0 \\
\hline Caimito (Star apple) & 0.0 & 0.0 & 0.4 & $a$ & $a$ & $a$ & 0.4 \\
\hline Black sapote & 0.1 & 0.3 & 0.0 & $a$ & $a$ & $a$ & 0.4 \\
\hline Canistel & 2.2 & 0.0 & 0.6 & $a$ & $a$ & $a$ & 2.8 \\
\hline
\end{tabular}

Not reported because of confidentiality restrictions.

Source: Survey data, Florida Agricultural Market Research Center, University of Florida, 1995. 
Appendix Table A-3. Estimates of post-hurricane sales potential for selected tropical fruits, Dade County, Florida, in pounds.

\begin{tabular}{|c|c|c|c|c|c|c|}
\hline \multirow[b]{2}{*}{ Fruit Crop } & \multirow{2}{*}{$\begin{array}{l}\text { Estimated } \\
\text { Production } \\
1994\end{array}$} & \multicolumn{5}{|c|}{ Distribution of Sales Volume } \\
\hline & & $\begin{array}{l}\text { Not } \\
\text { sold }\end{array}$ & $\begin{array}{l}\text { Sold directly } \\
\text { to consumers }\end{array}$ & $\begin{array}{c}\text { Sold on-tree } \\
\text { to local dealers }\end{array}$ & $\begin{array}{c}\text { Sold to local } \\
\text { packer/shippers }\end{array}$ & $\begin{array}{l}\text { Self packed } \\
\text { and shipped }\end{array}$ \\
\hline & $(-\cdots$ & $\cdots$ & $\ldots \ldots 1,000$ & nds $\ldots \ldots-\ldots$ & 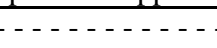 & $-----)$ \\
\hline Avocado & 83,896 & 21 & 26 & 196 & 36,055 & 47,597 \\
\hline Tahiti lime & 78,540 & 136 & 35 & 0 & 47,402 & 30,947 \\
\hline Mango & 38,750 & 31 & 1,523 & 1,702 & 17,559 & 17,935 \\
\hline Carambola & 21,214 & 248 & 5 & 368 & 11,464 & 9,128 \\
\hline Lychee & 8,566 & 85 & 597 & 648 & 3,843 & 3,393 \\
\hline Papaya & 13,790 & 11 & 9 & 4 & 4,701 & 9,064 \\
\hline Mamey sapote & 5,680 & 4 & 23 & 2,687 & 307 & 2,659 \\
\hline Banana/plantain & 4,500 & 61 & 212 & 173 & 1,654 & 2,399 \\
\hline Longan & 4,608 & 26 & 89 & 607 & 1,495 & 2,392 \\
\hline Guava & 4,925 & 1 & 103 & 51 & 18 & 4,752 \\
\hline Barbados cherry (Acerola) & 1,215 & 810 & 0 & 0 & $a$ & $a$ \\
\hline Passion fruit & 1,333 & 6 & 0 & 2 & 134 & 1,191 \\
\hline Atemoya & 263 & $\mathbf{0}$ & $\mathbf{0}$ & 0 & 10 & 253 \\
\hline Pummelo & 875 & 1 & 215 & 13 & 459 & 188 \\
\hline Jackfruit & 881 & 6 & 0 & 120 & 130 & 624 \\
\hline Kumquat & 216 & 2 & 3 & 0 & 70 & 142 \\
\hline Citrus (misc.) & 648 & 2 & 0 & 0 & $a$ & $a$ \\
\hline Sugar apple & 124 & 1 & 6 & 43 & 24 & 50 \\
\hline Key lime & 221 & 0 & 0 & 61 & $a$ & $a$ \\
\hline Sapodilla & 120 & 1 & 24 & 78 & $a$ & $a$ \\
\hline Coconut palm & 90 & 75 & 0 & 1 & $a$ & $a$ \\
\hline Wax jambu & 159 & 1 & 0 & 1 & 32 & 124 \\
\hline Persimmon & 36 & 0 & 0 & 12 & 24 & 0 \\
\hline Caimito (Star apple) & 24 & 0 & 0 & 0 & $a$ & $a$ \\
\hline Black sapote & 29 & 0 & 0 & 0 & $a$ & $a$ \\
\hline Canistel & 40 & 1 & 0 & 0 & $a$ & $a$ \\
\hline White sapote & 19 & 7 & 7 & 7 & $a$ & $a$ \\
\hline
\end{tabular}

$a$

Not reported because of confidentiality restrictions.

Source: Survey data, Florida Agricultural Market Research Center, University of Florida, 1995. 
Appendix Table A-4. Number of growers and shippers, estimated production at maturity for plantings as of 12-31-94, and volume of production self-packed and shipped by type of fruit.

\begin{tabular}{|c|c|c|c|c|c|c|c|c|}
\hline \multirow[t]{2}{*}{ Fruit Crop } & \multicolumn{2}{|c|}{$\begin{array}{c}\text { Number of growers as } \\
\text { of } 12-31-94 \\
\end{array}$} & \multirow{2}{*}{$\begin{array}{c}\text { Total } \\
\text { acreage } \\
\text { estimates } \\
1994 \\
\text { acres }\end{array}$} & \multirow{2}{*}{$\begin{array}{c}\text { Total } \\
\text { production } \\
\text { at maturity } \\
1,000 \mathrm{lbs}\end{array}$} & \multicolumn{2}{|c|}{$\begin{array}{c}\text { Number of } \\
\text { packer/shippers }\end{array}$} & \multirow{2}{*}{$\begin{array}{c}\begin{array}{c}\text { Percent of } \\
\text { production } \\
\text { self packed } \\
\text { and shipped }\end{array} \\
\text { percent }\end{array}$} & \multirow{2}{*}{$\begin{array}{c}\begin{array}{c}\text { Total production } \\
\text { self packed and } \\
\text { shipped }\end{array} \\
1,000 \mathrm{lbs}\end{array}$} \\
\hline & raw no. $a$ & adjusted no. & & & raw no. & adjusted no. & & \\
\hline Avocado & 95 & 114 & 6,040 & 83,896 & 17 & 20 & 56.7 & 47,597 \\
\hline Tahiti lime & 24 & 29 & 2,618 & 78,540 & 8 & 10 & 39.4 & 30,947 \\
\hline Mango & 62 & 75 & 1,550 & 38,750 & 17 & 20 & 46.3 & 17,935 \\
\hline Carambola & 63 & 76 & 532 & 21,214 & 11 & 13 & 43.0 & 9,128 \\
\hline Lychee & 115 & 138 & 511 & 8,566 & 12 & 14 & 39.6 & 3,393 \\
\hline Papaya & 18 & 22 & 394 & 13,790 & 9 & 11 & 65.7 & 9,064 \\
\hline Mamey sapote & 26 & 31 & 307 & 5,680 & 9 & 11 & 46.8 & 2,659 \\
\hline Banana/plantain & 19 & 23 & 300 & 4,500 & 9 & 11 & 53.3 & 2,399 \\
\hline Longan & 80 & 96 & 294 & 4,608 & 19 & 23 & 51.9 & 2,392 \\
\hline Guava & 12 & 14 & 197 & 4,925 & 7 & 8 & 96.5 & 4,752 \\
\hline Barbados cherry (Acerola) & 5 & 6 & 73 & 1,215 & $b$ & $b$ & $b$ & $b$ \\
\hline Passion fruit & 11 & 13 & 62 & 1,333 & 3 & 4 & 89.4 & 1,191 \\
\hline Atemoya & 12 & 14 & 41 & 263 & 4 & 5 & 96.1 & 253 \\
\hline Pummelo & 13 & 16 & 35 & 875 & 5 & 6 & 21.4 & 188 \\
\hline Jackfruit & 12 & 14 & 27 & 881 & 4 & 5 & 70.9 & 624 \\
\hline Kumquat & 9 & 11 & 26 & 216 & 4 & 5 & 65.6 & 142 \\
\hline Citrus (misc.) & 5 & 6 & 24 & 648 & $b$ & $b$ & $b$ & $b$ \\
\hline Sugar apple & 20 & 24 & 23 & 124 & 6 & 7 & 40.6 & 50 \\
\hline Key lime & 7 & 8 & 18 & 221 & $b$ & $b$ & $b$ & $b$ \\
\hline Sapodilla & 10 & 12 & 12 & 120 & $b$ & $b$ & $b$ & $b$ \\
\hline Coconut palm & 5 & 6 & 9 & 90 & $b$ & $b$ & $b$ & $b$ \\
\hline Wax jambu & 3 & 4 & 8 & 159 & 3 & 4 & 78.1 & 124 \\
\hline Persimmon & 4 & 5 & 4 & 36 & 0 & 0 & 0.0 & 0 \\
\hline Black sapote & 5 & 6 & 2 & 29 & $b$ & $b$ & $b$ & $b$ \\
\hline Canistel & 3 & 4 & 2 & 40 & $b$ & $b$ & $b$ & $b$ \\
\hline White sapote & 7 & 8 & 1 & 19 & $b$ & $b$ & $b$ & $b$ \\
\hline
\end{tabular}

${ }^{\mathrm{a}}$ The raw number is the actural number obtained by surveying a sample of 245 persons; because there were 290 in the universe and 45 could not be reached or refused to cooperate, the adjusted number reflects the estimated number in the universe.

${ }^{\mathrm{b}}$ Not reported separately because of confidentiality restrictions, i.e., less than three growers or shippers reported growing or handling these fruits.

Source: Survey data, Florida Agricultural Market Research Center, University of Florida, 1995. 
Appendix Table B-1. Top 25 Hispanic and Asian U.S. Market Regions.

\begin{tabular}{|c|c|c|c|c|c|c|c|}
\hline \multirow[b]{2}{*}{ Market Region Racial/Ethnic Group } & \multicolumn{2}{|l|}{ Rank } & \multicolumn{4}{|c|}{ Population } & \multirow{3}{*}{$\begin{array}{r}\text { Change, } \\
1990-1994 \\
\text { (Percent) }\end{array}$} \\
\hline & Hispanic & Asian & \multicolumn{2}{|c|}{1990} & \multicolumn{2}{|c|}{$1994 * *$} & \\
\hline & & & $(1,000)$ & (Percent) & $(1,000)$ & (Percent) & \\
\hline Los Angeles & 1 & 1 & & & & & \\
\hline White & & & 12,839 & 67.4 & 13,728 & 66.4 & 6.9 \\
\hline Black & & & 1,503 & 7.9 & 1,633 & 7.9 & 8.7 \\
\hline Indian (American, Eskimo, Aleut) & & & 134 & 0.7 & 145 & 0.7 & 8.3 \\
\hline Asian or Pacific Islander & & & 1,607 & 8.4 & 1,861 & 9.0 & 15.8 \\
\hline Other & & & 2,956 & 15.5 & 3,329 & 16.1 & 12.6 \\
\hline Hispanic* & & & 5,642 & 29.6 & 6,457 & 31.2 & 14.4 \\
\hline Total Population & & & 19,039 & 100.0 & 20,696 & 100.1 & 8.7 \\
\hline New York & 2 & 3 & & & & & \\
\hline White & & & 12,231 & 69.9 & 12,458 & 68.9 & 1.9 \\
\hline Black & & & 3,230 & 18.5 & 3,363 & 18.6 & 4.1 \\
\hline Indian (American, Eskimo, Aleut) & & & 40 & 0.2 & 54 & 0.3 & 36.4 \\
\hline Asian or Pacific Islander & & & 856 & 4.9 & 994 & 5.5 & 16.2 \\
\hline Other & & & 1,149 & 6.6 & 1,211 & 6.7 & 5.5 \\
\hline Hispanic* & & & 2,647 & 15.1 & 2,911 & 16.1 & 10.0 \\
\hline Total Population & & & 17,505 & 100.0 & 18,082 & 100.0 & 3.3 \\
\hline San Antonio & 3 & 24 & & & & & \\
\hline White & & & 3,360 & 76.3 & 3,551 & 75.2 & 5.7 \\
\hline Black & & & 254 & 5.8 & 279 & 5.9 & 9.7 \\
\hline Indian (American, Eskimo, Aleut) & & & 15 & 0.3 & 19 & 0.4 & 25.0 \\
\hline Asian or Pacific Islander & & & 51 & 1.2 & 61 & 1.3 & 20.9 \\
\hline Other & & & 722 & 16.4 & 812 & 17.2 & 12.5 \\
\hline Hispanic* & & & 2,075 & 47.1 & 2,271 & 48.1 & 9.5 \\
\hline Total Population & & & 4,402 & 100.0 & 4,722 & 100.0 & 7.3 \\
\hline Albuquerque & 4 & 33 & & & & & \\
\hline White & & & 2,768 & 78.1 & 2,915 & 77.9 & 5.3 \\
\hline Black & & & 120 & 3.4 & 127 & 3.4 & 6.3 \\
\hline Indian (American, Eskimo, Aleut) & & & 144 & 4.1 & 153 & 4.1 & 6.5 \\
\hline Asian or Pacific Islander & & & 31 & 0.9 & 37 & 1.0 & 19.6 \\
\hline Other & & & 479 & 13.5 & 505 & 13.5 & 5.4 \\
\hline Hispanic* & & & 1,348 & 38.0 & 1,473 & 39.4 & 9.3 \\
\hline Total Population & & & 3,542 & 100.0 & 3,739 & 99.9 & 5.5 \\
\hline San Francisco & 5 & 2 & & & & & \\
\hline White & & & 6,559 & 73.7 & 6,924 & 72.8 & 5.6 \\
\hline Black & & & 656 & 7.4 & 704 & 7.4 & 7.3 \\
\hline Indian (American, Eskimo, Aleut) & & & 87 & 1.0 & 95 & 1.0 & 9.5 \\
\hline Asian or Pacific Islander & & & 1,077 & 12.1 & 1,227 & 12.9 & 14.0 \\
\hline Other & & & 524 & 5.9 & 571 & 6.0 & 8.8 \\
\hline Hispanic* & & & 1,209 & 13.6 & 1,380 & 14.5 & 14.1 \\
\hline Total Population & & & 8,903 & 100.0 & 9,520 & 100.1 & 6.9 \\
\hline Miami & 6 & 21 & & & & & \\
\hline White & & & 3,568 & 79.2 & 3,881 & 78.7 & 8.7 \\
\hline Black & & & 743 & 16.5 & 823 & 16.7 & 10.8 \\
\hline Indian (American, Eskimo, Aleut) & & & 9 & 0.2 & 10 & 0.2 & 15.5 \\
\hline Asian or Pacific Islander & & & 53 & 1.2 & 69 & 1.4 & 29.5 \\
\hline Other & & & 132 & 2.9 & 153 & 3.1 & 16.1 \\
\hline Hispanic* & & & 1,146 & 25.4 & 1,333 & 27.0 & 16.3 \\
\hline Total Population & & & 4,505 & 100.0 & 4,936 & 100.1 & 9.6 \\
\hline Chicago & 7 & 4 & & & & & \\
\hline White & & & 7,152 & 74.8 & 7,340 & 74.4 & 2.6 \\
\hline Black & & & 1,636 & 17.1 & 1,677 & 17 & 2.5 \\
\hline Indian (American, Eskimo, Aleut) & & & 20 & 0.2 & 20 & 0.2 & -2.3 \\
\hline Asian or Pacific Islander & & & 267 & 2.8 & 296 & 3 & 10.9 \\
\hline Other & & & 489 & 5.1 & 523 & 5.3 & 6.9 \\
\hline Hispanic* & & & 908 & 9.5 & 1,005 & 10.2 & 10.8 \\
\hline Total Population & & & 9,564 & 100.0 & 9,855 & 99.9 & 3.0 \\
\hline
\end{tabular}


Appendix Table B-1. Top 25 Hispanic and Asian U.S. market regions, continued.

\begin{tabular}{|c|c|c|c|c|c|c|c|}
\hline \multirow[b]{2}{*}{ Market Region Racial/Ethnic Group } & \multicolumn{2}{|l|}{ Rank } & \multicolumn{4}{|c|}{ Population } & \multirow{2}{*}{$\begin{array}{r}\text { Change, } \\
1990-1994 \\
\end{array}$} \\
\hline & Hispanic & Asian & & 990 & & $994^{* * *}$ & \\
\hline & & & $(1,000)$ & (Percent) & $(1,000)$ & (Percent) & (Percent) \\
\hline $\begin{array}{l}\text { Houston } \\
\text { White }\end{array}$ & 8 & 9 & 3,194 & 69.2 & 3,363 & 68.4 & 5.3 \\
\hline Black & & & 832 & 18.0 & 890 & 18.1 & 6.9 \\
\hline Indian (American, Eskimo, Aleut) & & & 14 & 0.3 & 15 & 0.3 & 2.7 \\
\hline Asian or Pacific Islander & & & 142 & 3.1 & 167 & 3.4 & 17.3 \\
\hline Other & & & 432 & 9.4 & 487 & 9.9 & 12.6 \\
\hline Hispanic* & & & 840 & 18.2 & 955 & 19.4 & 13.7 \\
\hline Total Population & & & 4,615 & 100.0 & 4,921 & 100.1 & 6.6 \\
\hline Fresno & 9 & 6 & & & & & \\
\hline White & & & 1,870 & 69.6 & 1,980 & 68.5 & 5.9 \\
\hline Black & & & 115 & 4.3 & 127 & 4.4 & 10.9 \\
\hline Indian (American, Eskimo, Aleut) & & & 32 & 1.2 & 32 & 1.1 & -1.6 \\
\hline Asian or Pacific Islander & & & 198 & 7.4 & 231 & 8.0 & 16.6 \\
\hline Other & & & 470 & 17.5 & 517 & 17.9 & 10.1 \\
\hline Hispanic** & & & 801 & 29.8 & 907 & 31.4 & 13.3 \\
\hline Total Population & & & 2,686 & 100.0 & 2,888 & 99.9 & 7.5 \\
\hline Phoenix & 10 & 22 & & & & & \\
\hline White & & & 2,968 & 81.0 & 3,215 & 80.5 & 8.3 \\
\hline Black & & & 110 & 3.0 & 124 & 3.1 & 12.5 \\
\hline Indian (American, Eskimo, Aleut) & & & 205 & 5.6 & 220 & 5.5 & 7.4 \\
\hline Asian or Pacific Islander & & & 54 & 1.5 & 68 & 1.7 & 25.4 \\
\hline Other & & & 329 & 9.0 & 367 & 9.2 & 11.7 \\
\hline Hispanic* & & & 681 & 18.6 & 771 & 19.3 & 13.2 \\
\hline Total Population & & & 3,665 & 100.0 & 3,993 & 100.0 & 9.0 \\
\hline Dallas & 11 & 11 & & & & & \\
\hline White & & & 4,894 & 76.8 & 5,193 & 76.2 & 6.1 \\
\hline Black & & & 981 & 15.4 & 1,049 & 15.4 & 7.0 \\
\hline Indian (American, Eskimo, Aleut) & & & 32 & 0.5 & 34 & 0.5 & 7.0 \\
\hline Asian or Pacific Islander & & & 107 & 1.7 & 129 & 1.9 & 21.1 \\
\hline Other & & & 356 & 5.6 & 409 & 6.0 & 14.9 \\
\hline Hispanic** & & & 631 & 9.9 & 743 & 10.9 & 17.7 \\
\hline Total Population & & & 6,370 & 100.0 & 6,815 & 100.0 & 7.0 \\
\hline Denver & 12 & 17 & & & & & \\
\hline White & & & 3,221 & 88.8 & 3,422 & 88.5 & 6.3 \\
\hline Black & & & 135 & 3.7 & 151 & 3.9 & 11.5 \\
\hline Indian (American, Eskimo, Aleut) & & & 38 & 1.1 & 43 & 1.1 & 11.6 \\
\hline Asian or Pacific Islander & & & 62 & 1.7 & 73 & 1.9 & 18.2 \\
\hline Other & & & 169 & 4.7 & 178 & 4.6 & 5.0 \\
\hline Hispanic* & & & 420 & 11.6 & 464 & 12.0 & 10.6 \\
\hline Total Population & & & 3,626 & 100.0 & 3,867 & 100.0 & 6.7 \\
\hline Tampa & 13 & 15 & & & & & \\
\hline White & & & 5,356 & 87.9 & 5,805 & 87.6 & 8.4 \\
\hline Black & & & 568 & 9.3 & 623 & 9.4 & 9.8 \\
\hline Indian (American, Eskimo, Aleut) & & & 22 & 0.4 & 20 & 0.3 & -10.0 \\
\hline Asian or Pacific Islander & & & 62 & 1.0 & 80 & 1.2 & 28.7 \\
\hline Other & & & 88 & 1.4 & 106 & 1.6 & 20.3 \\
\hline Hispanic* & & & 355 & 5.8 & 431 & 6.5 & 21.3 \\
\hline Total Population & & & 6,096 & 100.0 & 6,634 & 100.1 & 8.8 \\
\hline Boston & 14 & 8 & & & & & \\
\hline White & & & 8,021 & 92.5 & 8,118 & 91.9 & 1.2 \\
\hline Black & & & 308 & 3.6 & 327 & 3.7 & 6.1 \\
\hline Indian (American, Eskimo, Aleut) & & & 25 & 0.3 & 27 & 0.3 & 7.5 \\
\hline Asian or Pacific Islander & & & 165 & 1.9 & 194 & 2.2 & 17.7 \\
\hline Other & & & 152 & 1.8 & 159 & 1.8 & 4.4 \\
\hline Hispanic* & & & 289 & 3.3 & 327 & 3.7 & 12.9 \\
\hline Total Population & & & 8,671 & 100.0 & 8,825 & 99.9 & 1.8 \\
\hline
\end{tabular}


Appendix Table B-1. Top 25 Hispanic and Asian U.S. market regions, continued.

\begin{tabular}{|c|c|c|c|c|c|c|c|}
\hline \multirow[b]{2}{*}{ Market Region Racial/Ethnic Group } & \multicolumn{2}{|l|}{ Rank } & \multicolumn{4}{|c|}{ Population } & \multirow{3}{*}{$\begin{array}{r}\text { Change, } \\
1990-1994 \\
\text { (Percent) }\end{array}$} \\
\hline & Hispanic & Asian & \multicolumn{2}{|c|}{1990} & \multicolumn{2}{|c|}{$1994 * *$} & \\
\hline Baltimore/Washington & & & $(1,000)$ & (Percent) & $(1,000)$ & (Percent) & \\
\hline $\begin{array}{l}\text { Dalminore } \\
\text { White }\end{array}$ & 13 & $J$ & 4,475 & 68.4 & 4,843 & 68.2 & 8.2 \\
\hline Black & & & 1,717 & 26.3 & 1,832 & 25.8 & 6.7 \\
\hline Indian (American, Eskimo, Aleut) & & & 20 & 0.3 & 21 & 0.3 & 7.5 \\
\hline Asian or Pacific Islander & & & 238 & 3.6 & 291 & 4.1 & 22.5 \\
\hline Other & & & 91 & 1.4 & 114 & 1.6 & 25.5 \\
\hline Hispanic* & & & 236 & 3.6 & 298 & 4.2 & 26.5 \\
\hline Total Population & & & 6,539 & 100.0 & 7,101 & 100.0 & 8.6 \\
\hline Hartford & 16 & 20 & & & & & \\
\hline White & & & 3,593 & 87.6 & 3,611 & 87.0 & 0.5 \\
\hline Black & & & 313 & 7.6 & 328 & 7.9 & 4.7 \\
\hline Indian (American, Eskimo, Aleut) & & & 8 & 0.2 & 8 & 0.2 & 0.2 \\
\hline Asian or Pacific Islander & & & 59 & 1.4 & 71 & 1.7 & 20.5 \\
\hline Other & & & 127 & 3.1 & 137 & 3.3 & 8.0 \\
\hline Hispanic* & & & 253 & 6.2 & 287 & 6.9 & 13.1 \\
\hline Total Population & & & 4,099 & 100.0 & 4,155 & 100.1 & 1.4 \\
\hline Philadelphia & 17 & 10 & & & & & \\
\hline White & & & 4,890 & 77.3 & 4,985 & 76.9 & 1.9 \\
\hline Black & & & 1,165 & 18.4 & 1,199 & 18.5 & 2.9 \\
\hline Indian (American, Eskimo, Aleut) & & & 14 & 0.2 & 13 & 0.2 & -4.7 \\
\hline Asian or Pacific Islander & & & 128 & 2.0 & 149 & 2.3 & 16.1 \\
\hline Other & & & 133 & 2.1 & 136 & 2.1 & 2.4 \\
\hline Hispanic* & & & 234 & 3.7 & 266 & 4.1 & 13.6 \\
\hline Total Population & & & 6,330 & 100.0 & 6,483 & 100.0 & 2.4 \\
\hline Seattle & 18 & 7 & & & & & \\
\hline White & & & 3,376 & 87.7 & 3,623 & 87.0 & 7.3 \\
\hline Black & & & 136 & 3.5 & 154 & 3.7 & 13.2 \\
\hline Indian (American, Eskimo, Aleut) & & & 64 & 1.7 & 71 & 1.7 & 10.1 \\
\hline Asian or Pacific Islander & & & 193 & 5.0 & 225 & 5.4 & 16.7 \\
\hline Other & & & 82 & 2.1 & 92 & 2.2 & 11.6 \\
\hline Hispanic* & & & 157 & 4.1 & 187 & 4.5 & 19.4 \\
\hline Total Population & & & 3,852 & 100.0 & 4,164 & 100.0 & 8.1 \\
\hline Salt Lake City & 19 & 28 & & & & & \\
\hline White & & & 2,546 & 93.7 & 2,731 & 93.4 & 7.2 \\
\hline Black & & & 16 & 0.6 & 18 & 0.6 & 12.1 \\
\hline Indian (American, Eskimo, Aleut) & & & 39 & 1.4 & 44 & 1.5 & 11.4 \\
\hline Asian or Pacific Islander & & & 43 & 1.6 & 50 & 1.7 & 16.6 \\
\hline Other & & & 74 & 2.7 & 82 & 2.8 & 10.1 \\
\hline Hispanic* & & & 151 & 5.6 & 172 & 5.9 & 14.1 \\
\hline Total Population & & & 2,718 & 100.0 & 2,924 & 100.0 & 7.5 \\
\hline Portland, OR & 20 & 12 & & & & & \\
\hline White & & & 3,106 & 92.9 & 3,298 & 92.5 & 6.2 \\
\hline Black & & & 51 & 1.5 & 57 & 1.6 & 12.6 \\
\hline Indian (American, Eskimo, Aleut) & & & 57 & 1.7 & 57 & 1.6 & 0.7 \\
\hline Asian or Pacific Islander & & & 77 & 2.3 & 93 & 2.6 & 20.2 \\
\hline Other & & & 51 & 1.5 & 57 & 1.6 & 10.9 \\
\hline Hispanic* & & & 124 & 3.7 & 146 & 4.1 & 18.2 \\
\hline Total Population & & & 3,342 & 100.0 & 3,562 & 99.9 & 6.6 \\
\hline Detroit & 21 & 14 & & & & & \\
\hline White & & & 5,079 & 80.0 & 5,182 & 79.8 & 2.0 \\
\hline Black & & & 1,113 & 17.5 & 1,136 & 17.5 & 2.1 \\
\hline Indian (American, Eskimo, Aleut) & & & 31 & 0.5 & 32 & 0.5 & 5.7 \\
\hline Asian or Pacific Islander & & & 76 & 1.2 & 84 & 1.3 & 11.0 \\
\hline Other & & & 53 & 0.8 & 52 & 0.8 & -1.2 \\
\hline Hispanic* & & & 125 & 2.0 & 143 & 2.2 & 14.5 \\
\hline Total Population & & & 6,352 & 100.0 & 6,487 & 99.9 & 2.1 \\
\hline
\end{tabular}


Appendix Table B-1. Top 25 Hispanic and Asian U.S. market regions, continued.

\begin{tabular}{|c|c|c|c|c|c|c|c|}
\hline \multirow[b]{2}{*}{ Market Region Racial/Ethnic Group } & \multicolumn{2}{|l|}{ Rank } & \multicolumn{4}{|c|}{ Population } & \multirow{2}{*}{$\begin{array}{r}\text { Change, } \\
1990-1994\end{array}$} \\
\hline & Hispanic & Asian & & 990 & & $994 * *$ & \\
\hline & & & $(1,000)$ & (Percent) & $(1,000)$ & (Percent) & (Percent) \\
\hline $\begin{array}{c}\text { Kansas City } \\
\text { White }\end{array}$ & 22 & 27 & 3.637 & 891 & 3761 & 88.8 & 3.4 \\
\hline Black & & & 311 & 7.6 & 326 & 7.7 & 4.8 \\
\hline Indian (American, Eskimo, Aleut) & & & 29 & 0.7 & 30 & 0.7 & 4.0 \\
\hline Asian or Pacific Islander & & & 44 & 1.1 & 51 & 1.2 & 16.1 \\
\hline Other & & & 61 & 1.5 & 68 & 1.6 & 10.9 \\
\hline Hispanic* & & & 121 & 3.0 & 136 & 3.2 & 11.6 \\
\hline Total Population & & & 4,082 & 100.0 & 4,236 & 100.0 & 3.8 \\
\hline Milwaukee & 23 & 25 & & & & & \\
\hline White & & & 4,546 & 92.2 & 4,670 & 91.7 & 2.7 \\
\hline Black & & & 248 & 5.0 & 270 & 5.3 & 8.9 \\
\hline Indian (American, Eskimo, Aleut) & & & 43 & 0.9 & 46 & 0.9 & 5.8 \\
\hline Asian or Pacific Islander & & & 53 & 1.1 & 61 & 1.2 & 14.7 \\
\hline Other & & & 41 & 0.8 & 46 & 0.9 & 13.2 \\
\hline Hispanic** & & & 88 & 1.8 & 102 & 2.0 & 15.6 \\
\hline Total Population & & & 4,931 & 100.0 & 5,093 & 100.0 & 3.3 \\
\hline Scranton/Harrisburg & 24 & 36 & & & & & \\
\hline White & & & 4,133 & 95.4 & 4,251 & 95.1 & 2.8 \\
\hline Black & & & 117 & 2.7 & 125 & 2.8 & 7.1 \\
\hline Indian (American, Eskimo, Aleut) & & & 5 & 0.1 & 4 & 0.1 & -18.7 \\
\hline Asian or Pacific Islander & & & 31 & 0.7 & 36 & 0.8 & 14.6 \\
\hline Other & & & 46 & 1.1 & 49 & 1.1 & 7.5 \\
\hline Hispanic* & & & 86 & 2.0 & 98 & 2.2 & 13.9 \\
\hline Total Population & & & 4,333 & 100.0 & 4,465 & 99.9 & 3.1 \\
\hline Oklahoma City & 25 & 32 & & & & & \\
\hline White & & & 2,403 & 82.6 & 2,445 & 81.6 & 1.7 \\
\hline Black & & & 230 & 7.9 & 246 & 8.2 & 7.0 \\
\hline Indian (American, Eskimo, Aleut) & & & 204 & 7.0 & 225 & 7.5 & 9.9 \\
\hline Asian or Pacific Islander & & & 32 & 1.1 & 39 & 1.3 & 21.1 \\
\hline Other & & & 39 & 1.3 & 42 & 1.4 & 7.9 \\
\hline Hispanic* & & & 79 & 2.7 & 90 & 3.0 & 13.5 \\
\hline Total Population & & & 2,908 & 100.0 & 2,996 & 100.0 & 3.0 \\
\hline Charlotte & 26 & 16 & & & & & \\
\hline White & & & 5,963 & 77.6 & 6,318 & 77.4 & 6.0 \\
\hline Black & & & 1,549 & 20.2 & 1,649 & 20.2 & 6.5 \\
\hline Indian (American, Eskimo, Aleut) & & & 85 & 1.1 & 90 & 1.1 & 6.0 \\
\hline Asian or Pacific Islander & & & 58 & 0.8 & 73 & 0.9 & 27.3 \\
\hline Other & & & 30 & 0.4 & 41 & 0.5 & 34.9 \\
\hline Hispanic* & & & 74 & 1.0 & 90 & 1.1 & 21.6 \\
\hline Total Population & & & 7,684 & 100.0 & 8,171 & 100.1 & 6.3 \\
\hline Atlanta & 29 & 18 & & & & & \\
\hline White & & & 3,018 & 71.1 & 3,246 & 71.4 & 7.5 \\
\hline Black & & & 1,129 & 26.6 & 1,186 & 26.1 & 5.1 \\
\hline Indian (American, Eskimo, Aleut) & & & 9 & 0.2 & 9 & 0.2 & -2.3 \\
\hline Asian or Pacific Islander & & & 58 & 1.4 & 73 & 1.6 & 26.0 \\
\hline Other & & & 28 & 0.7 & 32 & 0.7 & 12.8 \\
\hline Hispanic* & & & 70 & 1.6 & 86 & 1.9 & 23.6 \\
\hline Total Population & & & 4,242 & 100.0 & 4,546 & 100.0 & 7.1 \\
\hline Cincinnati & 30 & 19 & & & & & \\
\hline White & & & 7,161 & 90.4 & 7,233 & 90.1 & 1.0 \\
\hline Black & & & 649 & 8.2 & 674 & 8.4 & 3.9 \\
\hline Indian (American, Eskimo, Aleut) & & & 16 & 0.2 & 16 & 0.2 & 1.9 \\
\hline Asian or Pacific Islander & & & 61 & 0.8 & 72 & 0.9 & 18.4 \\
\hline Other & & & 31 & 0.4 & 32 & 0.4 & 4.2 \\
\hline Hispanic* & & & 72 & 0.9 & 80 & 1.0 & 12.2 \\
\hline Total Population & & & 7,918 & 100.0 & 8,027 & 100.0 & 1.4 \\
\hline
\end{tabular}


Appendix Table B-1. Top 25 Hispanic and Asian U.S. market regions, continued.

\begin{tabular}{|c|c|c|c|c|c|c|c|}
\hline \multirow[b]{2}{*}{ Market Region Racial/Ethnic Group } & \multicolumn{2}{|l|}{ Rank } & \multicolumn{4}{|c|}{ Population } & \multirow{2}{*}{$\begin{array}{r}\text { Change } \\
1990-1994 \\
\end{array}$} \\
\hline & Hispanic & Asian & & 90 & & $994 * *$ & \\
\hline & & & $(1,000)$ & (Percent) & $(1,000)$ & (Percent) & \\
\hline $\begin{array}{c}\text { Richmond } \\
\text { White }\end{array}$ & 35 & 23 & 2,319 & 71.3 & 2,664 & 71.6 & 14.9 \\
\hline Black & & & 857 & 26.3 & 964 & 25.9 & 12.5 \\
\hline Indian (American, Eskimo, Aleut) & & & 10 & 0.3 & 11 & 0.3 & 9.2 \\
\hline Asian or Pacific Islander & & & 50 & 1.6 & 63 & 1.7 & 25.3 \\
\hline Other & & & 15 & 0.5 & 19 & 0.5 & 21.9 \\
\hline Hispanic** & & & 47 & 1.5 & 60 & 1.6 & 25.9 \\
\hline Total Population & & & 3,252 & 100.0 & 3,721 & 100.0 & 14.4 \\
\hline Minneapolis & 37 & 13 & & & & & \\
\hline White & & & 4,058 & 94.6 & 4,196 & 94.2 & 3.4 \\
\hline Black & & & 95 & 2.2 & 102 & 2.3 & 8.0 \\
\hline Indian (American, Eskimo, Aleut) & & & 42 & 1.0 & 45 & 1.0 & 5.0 \\
\hline Asian or Pacific Islander & & & 77 & 1.8 & 89 & 2.0 & 16.2 \\
\hline Other & & & 20 & 0.5 & 22 & 0.5 & 13.7 \\
\hline Hispanic* & & & 47 & 1.1 & 58 & 1.3 & 21.9 \\
\hline Total Population & & & 4,291 & 100.0 & 4,454 & 100.0 & 3.8 \\
\hline
\end{tabular}

* For the most part, Hispanics are included in the "white" category above, although some are included in the black category. Thus to avoid double counting, Hispanics are not included in the Total Population Figures.

** Projected 
Appendix Table B-2. Distribution of Chinese population by city.

\begin{tabular}{|c|c|c|c|c|}
\hline Rank & City & $\begin{array}{c}\text { Projected population, } \\
1994 \\
\end{array}$ & Percent & $\begin{array}{c}\text { Cumulative } \\
\text { Percent }\end{array}$ \\
\hline 1 & San Francisco & 418,043 & 24.7 & 24.7 \\
\hline 2 & Los Angeles & 390,491 & 23.1 & 47.7 \\
\hline 3 & New York & 371,050 & 21.9 & 69.6 \\
\hline 4 & Boston & 67,212 & 4.0 & 73.6 \\
\hline 5 & Balt./Wash. & 57,296 & 3.4 & 77.0 \\
\hline 6 & Chicago & 49,761 & 2.9 & 79.9 \\
\hline 7 & Houston & 38,564 & 2.3 & 82.2 \\
\hline 8 & Seattle & 37,073 & 2.2 & 84.4 \\
\hline 9 & Philadelphia & 33,281 & 2.0 & 86.3 \\
\hline 10 & Dallas & 22,801 & 1.3 & 87.7 \\
\hline 11 & Miami & 20,355 & 1.2 & 88.9 \\
\hline 12 & Fresno & 18,297 & 1.1 & 90.0 \\
\hline 13 & Portland & 17,673 & 1.0 & 91.0 \\
\hline 14 & Phoenix & 16,509 & 1.0 & 92.0 \\
\hline 15 & Hartford & 16,098 & 1.0 & 92.9 \\
\hline 16 & Detroit & 15,902 & 0.9 & 93.9 \\
\hline 17 & Atlanta & 14,868 & 0.9 & 94.8 \\
\hline 18 & Cincinnati & 14,767 & 0.9 & 95.6 \\
\hline 19 & Tampa & 13,302 & 0.8 & 96.4 \\
\hline 20 & Charlotte & 13,029 & 0.8 & 97.2 \\
\hline 21 & San Antonio & 11,784 & 0.7 & 97.9 \\
\hline 22 & Denver & 10,875 & 0.6 & 98.5 \\
\hline 23 & Minneapolis & 9,438 & 0.6 & 99.1 \\
\hline 24 & Milwaukee & 8,683 & 0.5 & 99.6 \\
\hline 25 & Richmond & 6,853 & 0.4 & 100.0 \\
\hline Totals & & $1,694,005$ & 100.0 & \\
\hline
\end{tabular}


Appndix Table B-3. Distribution of Filipino population by city.

\begin{tabular}{|c|c|c|c|c|}
\hline Rank & City & $\begin{array}{c}\text { Projected population, } \\
1994 \\
\end{array}$ & Percent & $\begin{array}{c}\text { Cumulative } \\
\text { Percent }\end{array}$ \\
\hline 1 & Los Angeles & 481,927 & 35.9 & 35.9 \\
\hline 2 & San Francisco & 326,937 & 24.3 & 60.2 \\
\hline 3 & New York & 122,040 & 9.1 & 69.3 \\
\hline 4 & Chicago & 72,429 & 5.4 & 74.7 \\
\hline 5 & Seattle & 51,120 & 3.8 & 78.5 \\
\hline 6 & Fresno & 49,600 & 3.7 & 82.2 \\
\hline 7 & Balt./Wash. & 38,782 & 2.9 & 85.1 \\
\hline 8 & Richmond & 26,957 & 2.0 & 87.1 \\
\hline 9 & Houston & 19,548 & 1.5 & 88.5 \\
\hline 10 & Philadelphia & 18,251 & 1.4 & 89.9 \\
\hline 11 & Tampa & 14,871 & 1.1 & 91.0 \\
\hline 12 & Detroit & 13,391 & 1.0 & 92.0 \\
\hline 13 & Boston & 11,521 & 0.9 & 92.8 \\
\hline 14 & Dallas & 11,298 & 0.8 & 93.7 \\
\hline 15 & Phoenix & 10,794 & 0.8 & 94.5 \\
\hline 16 & Miami & 10,253 & 0.8 & 95.2 \\
\hline 17 & Portland & 9,858 & 0.7 & 96.0 \\
\hline 18 & San Antonio & 9,558 & 0.7 & 96.7 \\
\hline 19 & Cincinnati & 7,864 & 0.6 & 97.3 \\
\hline 20 & Denver & 7,811 & 0.6 & 97.9 \\
\hline 21 & Charlotte & 7,430 & 0.6 & 98.4 \\
\hline 22 & Hartford & 7,020 & 0.5 & 98.9 \\
\hline 23 & Minneapolis & 4,925 & 0.4 & 99.3 \\
\hline 24 & Milwaukee & 4,781 & 0.4 & 99.6 \\
\hline 25 & Atlanta & 4,732 & 0.4 & 100.0 \\
\hline Totals & & $1,343,698$ & 100.0 & \\
\hline
\end{tabular}


Appendix Table B-4. Distribution of Asian Indian population by city.

\begin{tabular}{rlrrr} 
Rank & City & $\begin{array}{c}\text { Projected population, } \\
1994\end{array}$ & Percent & Cumulative Percent \\
\hline & & & & \\
1 & New York & 220,301 & 27.7 & 27.7 \\
2 & Los Angeles & 89,679 & 11.3 & 38.9 \\
3 & San Francisco & 71,428 & 9.0 & 47.9 \\
4 & Chicago & 66,965 & 8.4 & 56.3 \\
5 & Balt./Wash. & 52,957 & 6.7 & 63.0 \\
6 & Houston & 31,689 & 4.0 & 66.9 \\
7 & Philadelphia & 31,575 & 4.0 & 70.9 \\
8 & Boston & 26,015 & 3.3 & 74.2 \\
9 & Dallas & 22,808 & 2.9 & 77.0 \\
10 & Detroit & 20,806 & 2.6 & 79.7 \\
11 & Miami & 17,874 & 2.2 & 81.9 \\
12 & Fresno & 17,747 & 2.2 & 84.1 \\
13 & Cincinnati & 16,204 & 2.0 & 86.2 \\
14 & Hartford & 15,776 & 2.0 & 88.1 \\
15 & Tampa & 14,724 & 1.8 & 90.0 \\
16 & Charlotte & 13,734 & 1.7 & 91.7 \\
17 & Atlanta & 13,107 & 1.6 & 93.4 \\
18 & Minneapolis & 8,442 & 1.1 & 94.4 \\
19 & Seattle & 8,061 & 1.0 & 95.4 \\
20 & San Antonio & 8,018 & 1.0 & 96.4 \\
21 & Milwaukee & 7,361 & 0.9 & 97.4 \\
22 & Phoenix & 7,021 & 0.9 & 98.3 \\
23 & Richmond & 5,267 & 0.7 & 98.9 \\
24 & Portland & 4,511 & 0.6 & 99.5 \\
25 & Denver & 4,118 & 0.5 & 100.0 \\
& & & & \\
Totals & & 796,188 & 100.0 & \\
\hline
\end{tabular}


Appendix Table B-5. Distribution of Korean population by city.

\begin{tabular}{|c|c|c|c|c|}
\hline Rank & City & $\begin{array}{c}\text { Projected population, } \\
1994 \\
\end{array}$ & Percent & $\begin{array}{c}\text { Cumulative } \\
\text { Percent }\end{array}$ \\
\hline 1 & Los Angeles & 240,595 & 30.6 & 30.6 \\
\hline 2 & New York & 137,535 & 17.5 & 48.1 \\
\hline 3 & Balt./Wash. & 60,711 & 7.7 & 55.9 \\
\hline 4 & San Francisco & 55,838 & 7.1 & 63.0 \\
\hline 5 & Chicago & 42,669 & 5.4 & 68.4 \\
\hline 6 & Seattle & 32,250 & 4.1 & 72.5 \\
\hline 7 & Philadelphia & 29,022 & 3.7 & 76.2 \\
\hline 8 & Boston & 16,961 & 2.2 & 78.4 \\
\hline 9 & Dallas & 14,946 & 1.9 & 80.3 \\
\hline 10 & Minneapolis & 14,025 & 1.8 & 82.0 \\
\hline 11 & Atlanta & 13,656 & 1.7 & 83.8 \\
\hline 12 & Denver & 13,650 & 1.7 & 85.5 \\
\hline 13 & Detroit & 12,220 & 1.6 & 87.1 \\
\hline 14 & Portland & 12,126 & 1.5 & 88.6 \\
\hline 15 & Charlotte & 10,225 & 1.3 & 89.9 \\
\hline 16 & San Antonio & 10,133 & 1.3 & 91.2 \\
\hline 17 & Houston & 9,456 & 1.2 & 92.4 \\
\hline 18 & Cincinnati & 9,414 & 1.2 & 93.6 \\
\hline 19 & Fresno & 8,297 & 1.1 & 94.7 \\
\hline 20 & Phoenix & 8,204 & 1.0 & 95.7 \\
\hline 21 & Tampa & 8,151 & 1.0 & 96.7 \\
\hline 22 & Hartford & 7,530 & 1.0 & 97.7 \\
\hline 23 & Richmond & 7,442 & 0.9 & 98.6 \\
\hline 24 & Milwaukee & 6,616 & 0.8 & 99.5 \\
\hline 25 & Miami & 3,995 & 0.5 & 100.0 \\
\hline Totals & & 785,667 & 100.0 & \\
\hline
\end{tabular}


Appendix Table B-6. Distribution of Japanese population by city.

\begin{tabular}{|c|c|c|c|c|}
\hline Rank & City & $\begin{array}{c}\text { Projected population, } \\
1994 \\
\end{array}$ & Percent & $\begin{array}{c}\text { Cumulative } \\
\text { Percent }\end{array}$ \\
\hline 1 & Los Angeles & 235,824 & 37.2 & 37.2 \\
\hline 2 & San Francisco & 115,897 & 18.3 & 55.5 \\
\hline 3 & New York & 55,589 & 8.8 & 64.3 \\
\hline 4 & Seattle & 36,319 & 5.7 & 70.1 \\
\hline 5 & Chicago & 22,328 & 3.5 & 73.6 \\
\hline 6 & Fresno & 21,955 & 3.5 & 77.0 \\
\hline 7 & Portland & 15,309 & 2.4 & 79.5 \\
\hline 8 & Denver & 14,819 & 2.3 & 81.8 \\
\hline 9 & Balt./Wash. & 14,813 & 2.3 & 84.1 \\
\hline 10 & Boston & 11,841 & 1.9 & 86.0 \\
\hline 11 & Cincinnati & 9,253 & 1.5 & 87.5 \\
\hline 12 & Detroit & 8,763 & 1.4 & 88.9 \\
\hline 13 & Phoenix & 8,130 & 1.3 & 90.1 \\
\hline 14 & Charlotte & 7,187 & 1.1 & 91.3 \\
\hline 15 & Philadelphia & 6,535 & 1.0 & 92.3 \\
\hline 16 & Atlanta & 6,348 & 1.0 & 93.3 \\
\hline 17 & Dallas & 6,330 & 1.0 & 94.3 \\
\hline 18 & Hartford & 5,786 & 0.9 & 95.2 \\
\hline 19 & Tampa & 5,179 & 0.8 & 96.0 \\
\hline 20 & San Antonio & 5,042 & 0.8 & 96.8 \\
\hline 21 & Houston & 4,993 & 0.8 & 97.6 \\
\hline 22 & Minneapolis & 4,349 & 0.7 & 98.3 \\
\hline 23 & Miami & 3,762 & 0.6 & 98.9 \\
\hline 24 & Richmond & 3,722 & 0.6 & 99.5 \\
\hline 25 & Milwaukee & 3,220 & 0.5 & 100.0 \\
\hline Totals & & 633,293 & 100.0 & \\
\hline
\end{tabular}


Appendix Table B-7. Distribution of Vietnamese population by city.

\begin{tabular}{|c|c|c|c|c|}
\hline Rank & City & $\begin{array}{c}\text { Projected population, } \\
1994 \\
\end{array}$ & Percent & Cumulative Percent \\
\hline 1 & Los Angeles & 196,300 & 33.3 & 33.3 \\
\hline 2 & San Francisco & 110,333 & 18.7 & 52.0 \\
\hline 3 & Houston & 44,786 & 7.6 & 59.6 \\
\hline 4 & Balt./Wash. & 30,061 & 5.1 & 64.7 \\
\hline 5 & Dallas & 24,902 & 4.2 & 68.9 \\
\hline 6 & Seattle & 19,058 & 3.2 & 72.2 \\
\hline 7 & Boston & 18,107 & 3.1 & 75.3 \\
\hline 8 & New York & 17,460 & 3.0 & 78.2 \\
\hline 9 & Fresno & 14,509 & 2.5 & 80.7 \\
\hline 10 & Philadelphia & 12,142 & 2.1 & 82.7 \\
\hline 11 & Portland & 11,182 & 1.9 & 84.6 \\
\hline 12 & Minneapolis & 10,972 & 1.9 & 86.5 \\
\hline 13 & Tampa & 10,933 & 1.9 & 88.4 \\
\hline 14 & Chicago & 9,158 & 1.6 & 89.9 \\
\hline 15 & Denver & 8,607 & 1.5 & 91.4 \\
\hline 16 & Atlanta & 7,085 & 1.2 & 92.6 \\
\hline 17 & Charlotte & 7,058 & 1.2 & 93.8 \\
\hline 18 & San Antonio & 7,038 & 1.2 & 95.0 \\
\hline 19 & Hartford & 6,017 & 1.0 & 96.0 \\
\hline 20 & Phoenix & 5,754 & 1.0 & 97.0 \\
\hline 21 & Richmond & 5,234 & 0.9 & 97.8 \\
\hline 22 & Miami & 4,012 & 0.7 & 98.5 \\
\hline 23 & Cincinnati & 3,577 & 0.6 & 99.1 \\
\hline 24 & Milwaukee & 2,646 & 0.4 & 99.6 \\
\hline 25 & Detroit & 2,475 & 0.4 & 100.0 \\
\hline Totals & & 589,406 & 100.0 & \\
\hline
\end{tabular}


Appendix Table B-8. Distribution of Mexican population by city.

\begin{tabular}{rlrrr} 
Rank & City & $\begin{array}{c}\text { Projected population, } \\
1994\end{array}$ & Percent Cumulative Percent \\
\hline & & & & \\
1 & Los Angeles & $5,196,655$ & 35.7 & 35.7 \\
2 & San Antonio & $2,129,648$ & 14.7 & 50.4 \\
3 & Albuquerque & $1,148,663$ & 7.9 & 58.3 \\
4 & San Francisco & 975,251 & 6.7 & 65.0 \\
5 & Fresno & 834,736 & 5.7 & 70.8 \\
6 & Houston & 788,032 & 5.4 & 76.2 \\
7 & Chicago & 706,338 & 4.9 & 81.0 \\
8 & Phoenix & 701,430 & 4.8 & 85.9 \\
9 & Dallas & 646,981 & 4.5 & 90.3 \\
10 & Denver & 314,095 & 2.2 & 92.5 \\
11 & Seattle & 133,307 & 0.9 & 93.4 \\
12 & Salt Lake City & 128,887 & 0.9 & 94.3 \\
13 & Portland & 110,050 & 0.8 & 95.0 \\
14 & Kansas City & 109,636 & 0.8 & 95.8 \\
15 & Tampa & 108,695 & 0.7 & 96.5 \\
16 & New York & 106,057 & 0.7 & 97.3 \\
17 & Detroit & 98,994 & 0.7 & 97.9 \\
18 & Oklahoma City & 67,048 & 0.5 & 98.4 \\
19 & Milwaukee & 66,171 & 0.5 & 98.9 \\
20 & Miami & 63,223 & 0.4 & 99.3 \\
21 & Balt./Wash. & 41,871 & 0.3 & 99.6 \\
22 & Boston & 21,400 & 0.1 & 99.7 \\
23 & Philadelphia & 18,359 & 0.1 & 99.9 \\
24 & Hartford & 11,370 & 0.1 & 99.9 \\
25 & Scranton/Harrisburg & 9,894 & 0.1 & 100.0 \\
& & & & \\
Totals & & $14,536,791$ & 100.0 & \\
\hline & & & &
\end{tabular}


Appendix Table B-9. Distribution of Puerto Rican population by city.

\begin{tabular}{rlrcc} 
Rank & City & $\begin{array}{c}\text { Projected population, } \\
1994\end{array}$ & Percent Cumulative Percent \\
\hline & & & & \\
1 & New York & $1,322,239$ & 49.3 & 49.3 \\
2 & Hartford & 206,179 & 7.7 & 57.0 \\
3 & Philadelphia & 185,653 & 6.9 & 63.9 \\
4 & Chicago & 171,613 & 6.4 & 70.3 \\
5 & Tampa & 140,797 & 5.2 & 75.5 \\
6 & Boston & 136,747 & 5.1 & 80.6 \\
7 & Miami & 128,607 & 4.8 & 85.4 \\
8 & Los Angeles & 96,510 & 3.6 & 89.0 \\
9 & Scranton/Harrisburg & 67,470 & 2.5 & 91.5 \\
10 & San Francisco & 48,174 & 1.8 & 93.3 \\
11 & Balt./Wash. & 34,505 & 1.3 & 94.6 \\
12 & Milwaukee & 20,787 & 0.8 & 95.4 \\
13 & San Antonio & 20,155 & 0.8 & 96.1 \\
14 & Detroit & 13,616 & 0.5 & 96.6 \\
15 & Houston & 13,323 & 0.5 & 97.1 \\
16 & Dallas & 12,152 & 0.5 & 97.6 \\
17 & Fresno & 10,717 & 0.4 & 98.0 \\
18 & Phoenix & 9,643 & 0.4 & 98.4 \\
19 & Seattle & 9,572 & 0.4 & 98.7 \\
20 & Albuquerque & 9,079 & 0.3 & 99.1 \\
21 & Denver & 8,335 & 0.3 & 99.4 \\
22 & Oklahoma City & 5,298 & 0.2 & 99.6 \\
23 & Kansas City & 4,662 & 0.2 & 99.7 \\
24 & Portland & 4,014 & 0.1 & 99.9 \\
25 & Salt Lake City & 3,143 & 0.1 & 100.0 \\
& & & & \\
Totals & & $2,682,990$ & 100.0 & \\
\hline & & & &
\end{tabular}


Appendix Table B-10. Distribution of Cuban population by city.

\begin{tabular}{rlrcc} 
Rank & City & $\begin{array}{c}\text { Projected population, } \\
1994\end{array}$ & Percent Cumulative Percent \\
\hline & & & & \\
1 & Miami & 711,253 & 61.6 & 61.6 \\
2 & New York & 175,529 & 15.2 & 76.9 \\
3 & Los Angeles & 80,663 & 7.0 & 83.8 \\
4 & Tampa & 68,791 & 6.0 & 89.8 \\
5 & Chicago & 19,186 & 1.7 & 91.5 \\
6 & Balt./Wash. & 13,250 & 1.1 & 92.6 \\
7 & San Francisco & 11,062 & 1.0 & 93.6 \\
8 & Houston & 10,779 & 0.9 & 94.5 \\
9 & Boston & 10,406 & 0.9 & 95.4 \\
10 & Philadelphia & 9,455 & 0.8 & 96.2 \\
11 & Hartford & 7,667 & 0.7 & 96.9 \\
12 & Dallas & 7,265 & 0.6 & 97.5 \\
13 & San Antonio & 4,076 & 0.4 & 97.9 \\
14 & Detroit & 3,248 & 0.3 & 98.2 \\
15 & Phoenix & 2,757 & 0.2 & 98.4 \\
16 & Kansas City & 2,648 & 0.2 & 98.6 \\
17 & Scranton/Harrisburg & 2,515 & 0.2 & 98.9 \\
18 & Denver & 2,439 & 0.2 & 99.1 \\
19 & Seattle & 2,348 & 0.2 & 99.3 \\
20 & Portland & 1,805 & 0.2 & 99.4 \\
21 & Milwaukee & 1,739 & 0.2 & 99.6 \\
22 & Albuquerque & 1,511 & 0.1 & 99.7 \\
23 & Fresno & 1,428 & 0.1 & 99.8 \\
24 & Oklahoma City & 1,203 & 0.1 & 99.9 \\
25 & Salt Lake City & 762 & 0.1 & 100.0 \\
& & & & \\
Totals & & $1,153,785$ & 100.0 & \\
\hline & & & &
\end{tabular}


Appendix Table B-11. Distribution of Salvadoran population by city.

\begin{tabular}{|c|c|c|c|c|}
\hline Rank & City & $\begin{array}{c}\text { Projected population, } \\
1994 \\
\end{array}$ & Percent & Cumulative Percent \\
\hline 1 & Los Angeles & 321,961 & 50.9 & 50.9 \\
\hline 2 & New York & 69,319 & 11.0 & 61.9 \\
\hline 3 & San Francisco & 63,662 & 10.1 & 71.9 \\
\hline 4 & Balt./Wash. & 60,747 & 9.6 & 81.5 \\
\hline 5 & Houston & 47,193 & 7.5 & 89.0 \\
\hline 6 & Dallas & 14,504 & 2.3 & 91.3 \\
\hline 7 & Miami & 11,713 & 1.9 & 93.1 \\
\hline 8 & Boston & 11,635 & 1.8 & 95.0 \\
\hline 9 & Chicago & 6,892 & 1.1 & 96.1 \\
\hline 10 & Fresno & 5,511 & 0.9 & 96.9 \\
\hline 11 & San Antonio & 4,142 & 0.7 & 97.6 \\
\hline 12 & Phoenix & 2,524 & 0.4 & 98.0 \\
\hline 13 & Tampa & 2,322 & 0.4 & 98.4 \\
\hline 14 & Seattle & 1,450 & 0.2 & 98.6 \\
\hline 15 & Hartford & 1,393 & 0.2 & 98.8 \\
\hline 16 & Philadelphia & 1,198 & 0.2 & 99.0 \\
\hline 17 & Salt Lake City & 1,106 & 0.2 & 99.2 \\
\hline 18 & Albuquerque & 1,104 & 0.2 & 99.4 \\
\hline 19 & Portland & 1,096 & 0.2 & 99.5 \\
\hline 20 & Denver & 743 & 0.1 & 99.6 \\
\hline 21 & Scranton/Harrisburg & 523 & 0.1 & 99.7 \\
\hline 22 & Kansas City & 468 & 0.1 & 99.8 \\
\hline 23 & Oklahoma City & 456 & 0.1 & 99.9 \\
\hline 24 & Detroit & 412 & 0.1 & 99.9 \\
\hline 25 & Milwaukee & 372 & 0.1 & 100.0 \\
\hline Totals & & 632,446 & 100.0 & \\
\hline
\end{tabular}


Appendix Table B-12. Distribution of Dominican population by city.

\begin{tabular}{rlrcc} 
Rank & City & $\begin{array}{c}\text { Projected population, } \\
1994\end{array}$ & Percent Cumulative Percent \\
\hline & & & & \\
1 & New York & 444,787 & 78.9 & 78.9 \\
2 & Boston & 44,938 & 8.0 & 86.9 \\
3 & Miami & 32,880 & 5.8 & 92.7 \\
4 & Balt./Wash. & 6,800 & 1.2 & 93.9 \\
5 & Tampa & 6,401 & 1.1 & 95.0 \\
6 & Los Angeles & 5,245 & 0.9 & 96.0 \\
7 & Hartford & 5,170 & 0.9 & 96.9 \\
8 & Philadelphia & 4,768 & 0.8 & 97.7 \\
9 & Chicago & 2,434 & 0.4 & 98.2 \\
10 & Scranton/Harrisburg & 1,933 & 0.3 & 98.5 \\
11 & San Francisco & 1,717 & 0.3 & 98.8 \\
12 & Houston & 1,340 & 0.2 & 99.0 \\
13 & San Antonio & 949 & 0.2 & 99.2 \\
14 & Dallas & 726 & 0.1 & 99.3 \\
15 & Detroit & 554 & 0.1 & 99.4 \\
16 & Albuquerque & 532 & 0.1 & 99.5 \\
17 & Denver & 530 & 0.1 & 99.6 \\
18 & Seattle & 418 & 0.1 & 99.7 \\
19 & Milwaukee & 383 & 0.1 & 99.8 \\
20 & Phoenix & 342 & 0.1 & 99.8 \\
21 & Fresno & 288 & 0.1 & 99.9 \\
22 & Kansas City & 224 & 0.0 & 99.9 \\
23 & Oklahoma City & 171 & 0.0 & 100.0 \\
24 & Salt Lake City & 167 & 0.0 & \\
25 & Portland & 97 & 0.0 & \\
& & & & \\
Totals & & 563,794 & 100.0 & \\
\hline & & & &
\end{tabular}


Appendix Table B-13. Distribution of Colombian population by city.

\begin{tabular}{rlrrr} 
Rank & City & $\begin{array}{c}\text { Projected population, } \\
1994\end{array}$ & Percent Cumulative Percent \\
\hline & & & & \\
1 & New York & 169,675 & 42.4 & 42.4 \\
2 & Miami & 81,252 & 20.3 & 62.7 \\
3 & Los Angeles & 39,569 & 9.9 & 72.6 \\
4 & San Antonio & 2,268 & 0.6 & 73.2 \\
5 & Albuquerque & 820 & 0.2 & 73.4 \\
6 & San Francisco & 8,213 & 2.1 & 75.4 \\
7 & Chicago & 11,072 & 2.8 & 78.2 \\
8 & Houston & 12,345 & 3.1 & 81.3 \\
9 & Fresno & 1,125 & 0.3 & 81.6 \\
10 & Phoenix & 1,762 & 0.4 & 82.0 \\
11 & Dallas & 3,594 & 0.9 & 82.9 \\
12 & Denver & 1,152 & 0.3 & 83.2 \\
13 & Tampa & 14,215 & 3.6 & 86.8 \\
14 & Boston & 16,087 & 4.0 & 90.8 \\
15 & Baltimore/Wash. & 11,087 & 2.8 & 93.6 \\
16 & Hartford & 9,118 & 2.3 & 95.8 \\
17 & Philadelphia & 6,288 & 1.6 & 97.4 \\
18 & Seattle & 1,427 & 0.4 & 97.8 \\
19 & Salt Lake City & 1,003 & 0.3 & 98.0 \\
20 & Portland & 1,065 & 0.3 & 98.3 \\
21 & Detroit & 1,405 & 0.4 & 98.6 \\
22 & Kansas City & 1,048 & 0.3 & 98.9 \\
23 & Milwaukee & 1,084 & 0.3 & 99.2 \\
24 & Scranton/Harrisburg & 2,315 & 0.6 & 99.7 \\
25 & Oklahoma City & 1,035 & 0.3 & 100.0 \\
& & & & \\
Totals & & 400,024 & & \\
\hline & & & & \\
\cline { 3 - 4 } & & & & \\
& & & 0.3 & \\
\end{tabular}


Appendix Table B-14. Asian market region 1, Los Angeles, Ethnic detail.

\begin{tabular}{|c|c|c|c|}
\hline \multirow[b]{2}{*}{ Market Region Ethnic Subgroup } & \multicolumn{2}{|c|}{ Population } & \multirow{2}{*}{$\begin{array}{r}1994 \text { Percentage } \\
\text { distribution }\end{array}$} \\
\hline & 1990 & $1994^{*}$ & \\
\hline Los Angeles & (Number) & (Number) & (Percent) \\
\hline \multicolumn{4}{|l|}{ Asian or Pacific Islander: } \\
\hline Chinese & 337,136 & 390,491 & 21.0 \\
\hline Filipino & 416,078 & 481,927 & 25.9 \\
\hline Japanese & 203,602 & 235,824 & 12.7 \\
\hline Asian Indian & 77,426 & 89,679 & 4.8 \\
\hline Korean & 207,721 & 240,595 & 12.9 \\
\hline Vietnamese & 169,478 & 196,300 & 10.5 \\
\hline Cambodian & 40,949 & 47,430 & 2.5 \\
\hline Hmong & 4,340 & 5,027 & 0.3 \\
\hline Laotian & 17,325 & 20,067 & 1.1 \\
\hline Thai & 26,219 & 30,368 & 1.6 \\
\hline Other Asian & 45,875 & 53,135 & 2.9 \\
\hline \multicolumn{4}{|l|}{ Pacific Islander: } \\
\hline \multicolumn{4}{|l|}{ Polynesian: } \\
\hline Hawaiian & 19,523 & 22,613 & 1.2 \\
\hline Samoan & 19,606 & 22,709 & 1.2 \\
\hline Tongan & 3,202 & 3,709 & 0.2 \\
\hline Other Polynesian & 810 & 938 & 0.1 \\
\hline \multicolumn{4}{|l|}{ Micronesian: } \\
\hline Guamanian & 14,839 & 17,187 & 0.9 \\
\hline Other Micronesian & 954 & 1,105 & 0.1 \\
\hline Melanesian & 823 & 953 & 0.1 \\
\hline Pacific Islander, not specified & 618 & 716 & 0.0 \\
\hline Total Asian Population & $1,606,524$ & $1,860,773$ & 100.0 \\
\hline Total Population & $19,038,791$ & $20,695,929$ & - \\
\hline
\end{tabular}

* Projected

Appendix Table B-15. Asian market region 2, San Francisco, Ethnic detail.

\begin{tabular}{|c|c|c|c|}
\hline \multirow[b]{2}{*}{ Market Region Ethnic Subgroup } & \multicolumn{2}{|c|}{ Population } & \multirow{2}{*}{$\begin{array}{r}1994 \text { Percentage } \\
\text { distribution }\end{array}$} \\
\hline & 1990 & $1994 *$ & \\
\hline San Francisco & (Number) & (Number) & (Percent) \\
\hline \multicolumn{4}{|l|}{ Asian or Pacific Islander: } \\
\hline Chinese & 366,807 & 418,043 & 34.1 \\
\hline Filipino & 286,867 & 326,937 & 26.6 \\
\hline Japanese & 101,692 & 115,897 & 9.4 \\
\hline Asian Indian & 62,674 & 71,428 & 5.8 \\
\hline Korean & 48,994 & 55,838 & 4.6 \\
\hline Vietnamese & 96,810 & 110,333 & 9.0 \\
\hline Cambodian & 12,319 & 14,040 & 1.1 \\
\hline Hmong & 9,881 & 11,261 & 0.9 \\
\hline Laotian & 22,097 & 25,184 & 2.1 \\
\hline Thai & 5,247 & 5,980 & 0.5 \\
\hline Other Asian & 24,335 & 27,734 & 2.3 \\
\hline \multicolumn{4}{|l|}{ Pacific Islander: } \\
\hline \multicolumn{4}{|l|}{ Polynesian: } \\
\hline Hawaiian & 12,878 & 14,677 & 1.2 \\
\hline Samoan & 8,184 & 9,327 & 0.8 \\
\hline Tongan & 4,566 & 5,204 & 0.4 \\
\hline Other Polynesian & 404 & 460 & 0.0 \\
\hline \multicolumn{4}{|l|}{ Micronesian: } \\
\hline Guamanian & 7,418 & 8,454 & 0.7 \\
\hline Other Micronesian & 452 & 515 & 0.0 \\
\hline Melanesian & 3,909 & 4,455 & 0.4 \\
\hline Pacific Islander, not specified & 996 & 1,135 & 0.1 \\
\hline Total Asian Population & $1,076,530$ & $1,226,902$ & 100.0 \\
\hline Total Population & $8,903,125$ & $9,520,380$ & - - \\
\hline
\end{tabular}


Appendix Table B-16. Asian market region 3, New York, Ethnic detail.

\begin{tabular}{|c|c|c|c|}
\hline \multirow[b]{2}{*}{ Market Region Ethnic Subgroup } & \multicolumn{2}{|c|}{ Population } & \multirow{2}{*}{$\begin{array}{r}1994 \text { Percentage } \\
\text { distribution }\end{array}$} \\
\hline & 1990 & $1994^{*}$ & \\
\hline New York & (Number) & (Number) & (Percent) \\
\hline \multicolumn{4}{|l|}{ Asian or Pacific Islander: } \\
\hline Chinese & 319,227 & 371,050 & 37.3 \\
\hline Filipino & 104,995 & 122,040 & 12.3 \\
\hline Japanese & 47,825 & 55,589 & 5.6 \\
\hline Asian Indian & 189,532 & 220,301 & 22.2 \\
\hline Korean & 118,326 & 137,535 & 13.8 \\
\hline Vietnamese & 15,021 & 17,460 & 1.8 \\
\hline Cambodian & 2,803 & 3,258 & 0.3 \\
\hline Hmong & 16 & 19 & 0.0 \\
\hline Laotian & 799 & 929 & 0.1 \\
\hline Thai & 7,280 & 8,462 & 0.9 \\
\hline Other Asian & 46,100 & 53,584 & 5.4 \\
\hline \multicolumn{4}{|l|}{ Pacific Islander: } \\
\hline \multicolumn{4}{|l|}{ Polynesian: } \\
\hline Hawaiian & 1,322 & 1,537 & 0.2 \\
\hline Samoan & 361 & 420 & 0.0 \\
\hline Tongan & 14 & 16 & 0.0 \\
\hline Other Polynesian & 60 & 70 & 0.0 \\
\hline \multicolumn{4}{|l|}{ Micronesian: } \\
\hline Guamanian & 1,397 & 1,624 & 0.2 \\
\hline Other Micronesian & 80 & 93 & 0.0 \\
\hline Melanesian & 89 & 103 & 0.0 \\
\hline Pacific Islander, not specified & 352 & 409 & 0.0 \\
\hline Total Asian Population & 855,599 & 994,497 & 100.0 \\
\hline Total Population & $17,504,762$ & $18,081,759$ & - \\
\hline
\end{tabular}

* Projected

Appendix Table B-17. Asian market region 4, Chicago, Ethnic detail.

\begin{tabular}{|c|c|c|c|}
\hline \multirow[b]{2}{*}{ Market Region Ethnic Subgroup } & \multicolumn{2}{|c|}{ Population } & \multirow{2}{*}{$\begin{array}{r}1994 \text { Percentag } \\
\text { distributior }\end{array}$} \\
\hline & 1990 & $1994 *$ & \\
\hline Chicago & (Number) & (Number) & (Percent) \\
\hline \multicolumn{4}{|l|}{ Asian or Pacific Islander: } \\
\hline Chinese & 44,865 & 49,761 & 16.8 \\
\hline Filipino & 65,302 & 72,429 & 24.5 \\
\hline Japanese & 20,131 & 22,328 & 7.5 \\
\hline Asian Indian & 60,376 & 66,965 & 22.6 \\
\hline Korean & 38,470 & 42,669 & 14.4 \\
\hline Vietnamese & 8,257 & 9,158 & 3.1 \\
\hline Cambodian & 2,607 & 2,892 & 1.0 \\
\hline Hmong & 424 & 470 & 0.2 \\
\hline Laotian & 4,101 & 4,549 & 1.5 \\
\hline Thai & 4,832 & 5,359 & 1.8 \\
\hline Other Asian & 15,327 & 17,000 & 5.7 \\
\hline \multicolumn{4}{|l|}{ Pacific Islander: } \\
\hline \multicolumn{4}{|l|}{ Polynesian: } \\
\hline Hawaiian & 785 & 871 & 0.3 \\
\hline Samoan & 214 & 237 & 0.1 \\
\hline Tongan & 9 & 10 & 0.0 \\
\hline Other Polynesian & 35 & 39 & 0.0 \\
\hline \multicolumn{4}{|l|}{ Micronesian: } \\
\hline Guamanian & 997 & 1,106 & 0.4 \\
\hline Other Micronesian & 14 & 16 & 0.0 \\
\hline Melanesian & 0 & 0 & 0.0 \\
\hline Pacific Islander, not specified & 87 & 96 & 0.0 \\
\hline Total Asian Population & 266,833 & 295,955 & 100.0 \\
\hline Total Population & $9,563,681$ & $9,855,287$ & 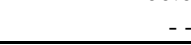 \\
\hline
\end{tabular}


Appendix Table B-18. Asian market region 5, Baltimore/Washington, Ethnic detail.

\begin{tabular}{|c|c|c|c|}
\hline \multirow[b]{2}{*}{ Market Region Ethnic Subgroup } & \multicolumn{2}{|c|}{ Population } & \multirow{2}{*}{$\begin{array}{r}1994 \text { Percentage } \\
\text { distribution }\end{array}$} \\
\hline & 1990 & $1994 *$ & \\
\hline Baltimore/Washington & (Number) & (Number) & (Percent) \\
\hline \multicolumn{4}{|l|}{ Asian or Pacific Islander: } \\
\hline Chinese & 46,774 & 57,296 & 19.7 \\
\hline Filipino & 31,660 & 38,782 & 13.3 \\
\hline Japanese & 12,093 & 14,813 & 5.1 \\
\hline Asian Indian & 43,232 & 52,957 & 18.2 \\
\hline Korean & 49,562 & 60,711 & 20.9 \\
\hline Vietnamese & 24,541 & 30,061 & 10.3 \\
\hline Cambodian & 4,185 & 5,126 & 1.8 \\
\hline Hmong & 7 & 9 & 0.0 \\
\hline Laotian & 2,492 & 3,053 & 1.0 \\
\hline Thai & 4,912 & 6,017 & 2.1 \\
\hline Other Asian & 15,769 & 19,316 & 6.6 \\
\hline \multicolumn{4}{|l|}{ Pacific Islander: } \\
\hline \multicolumn{4}{|l|}{ Polynesian: } \\
\hline Hawaiian & 897 & 1,099 & 0.4 \\
\hline Samoan & 270 & 331 & 0.1 \\
\hline Tongan & 17 & 21 & 0.0 \\
\hline Other Polynesian & 30 & 37 & 0.0 \\
\hline \multicolumn{4}{|l|}{ Micronesian: } \\
\hline Guamanian & 1,020 & 1,249 & 0.4 \\
\hline Other Micronesian & 153 & 187 & 0.1 \\
\hline Melanesian & 44 & 54 & 0.0 \\
\hline Pacific Islander, not specified & 27 & 33 & 0.0 \\
\hline Total Asian Population & 237,685 & 291,151 & 100.0 \\
\hline Total Population & $6,539,153$ & $7,101,236$ & $\ldots$ \\
\hline
\end{tabular}

* Projected

Appendix Table B-19. Asian market region 6, Fresno, Ethnic detail.

\begin{tabular}{|c|c|c|c|}
\hline \multirow[b]{2}{*}{ Market Region Ethnic Subgroup } & \multicolumn{2}{|c|}{ Population } & \multirow{2}{*}{$\begin{array}{r}1994 \text { Percentage } \\
\text { distribution }\end{array}$} \\
\hline & 1990 & $1994^{*}$ & \\
\hline Fresno & (Number) & (Number) & $\overline{\text { (Percent) }}$ \\
\hline \multicolumn{4}{|l|}{ Asian or Pacific Islander: } \\
\hline Chinese & 15,697 & 18,297 & 7.9 \\
\hline Filipino & 42,551 & 49,600 & 21.4 \\
\hline Japanese & 18,835 & 21,955 & 9.5 \\
\hline Asian Indian & 15,225 & 17,747 & 7.7 \\
\hline Korean & 7,118 & 8,297 & 3.6 \\
\hline Vietnamese & 12,447 & 14,509 & 6.3 \\
\hline Cambodian & 18,217 & 21,235 & 9.2 \\
\hline Hmong & 34,529 & 40,249 & 17.4 \\
\hline Laotian & 21,399 & 24,944 & 10.8 \\
\hline Thai & 784 & 914 & 0.4 \\
\hline Other Asian & 5,164 & 6,019 & 2.6 \\
\hline \multicolumn{4}{|l|}{ Pacific Islander: } \\
\hline \multicolumn{4}{|l|}{ Polynesian: } \\
\hline Hawaiian & 2,347 & 2,736 & 1.2 \\
\hline Samoan & 818 & 954 & 0.4 \\
\hline Tongan & 108 & 126 & 0.1 \\
\hline Other Polynesian & 73 & 85 & 0.0 \\
\hline \multicolumn{4}{|l|}{ Micronesian: } \\
\hline Guamanian & 1,897 & 2,211 & 1.0 \\
\hline Other Micronesian & 239 & 279 & 0.1 \\
\hline Melanesian & 799 & 931 & 0.4 \\
\hline Pacific Islander, not specified & 151 & 176 & 0.1 \\
\hline Total Asian Population & 198,398 & 231,263 & 100.0 \\
\hline Total Population & $2,685,636$ & $2,887,893$ & - - \\
\hline
\end{tabular}


Appendix Table B-20. Asian market region 7, Seattle, Ethnic detail.

\begin{tabular}{|c|c|c|c|}
\hline \multirow[b]{2}{*}{ Market Region Ethnic Subgroup } & \multicolumn{2}{|c|}{ Population } & \multirow{2}{*}{$\begin{array}{r}1994 \text { Percentage } \\
\text { distribution }\end{array}$} \\
\hline & 1990 & $1994^{*}$ & \\
\hline Seattle & (Number) & (Number) & (Percent) \\
\hline \multicolumn{4}{|l|}{ Asian or Pacific Islander: } \\
\hline Chinese & 31,774 & 37,073 & 16.5 \\
\hline Filipino & 43,814 & 51,120 & 22.7 \\
\hline Japanese & 31,128 & 36,319 & 16.2 \\
\hline Asian Indian & 6,909 & 8,061 & 3.6 \\
\hline Korean & 27,641 & 32,250 & 14.3 \\
\hline Vietnamese & 16,334 & 19,058 & 8.5 \\
\hline Cambodian & 10,011 & 11,680 & 5.2 \\
\hline Hmong & 356 & 415 & 0.2 \\
\hline Laotian & 5,007 & 5,842 & 2.6 \\
\hline Thai & 2,169 & 2,531 & 1.1 \\
\hline Other Asian & 5,098 & 5,948 & 2.6 \\
\hline \multicolumn{4}{|l|}{ Pacific Islander: } \\
\hline \multicolumn{4}{|l|}{ Polynesian: } \\
\hline Hawaiian & 4,311 & 5,030 & 2.2 \\
\hline Samoan & 3,374 & 3,937 & 1.8 \\
\hline Tongan & 142 & 166 & 0.1 \\
\hline Other Polynesian & 87 & 102 & 0.0 \\
\hline \multicolumn{4}{|l|}{ Micronesian: } \\
\hline Guamanian & 3,553 & 4,145 & 1.8 \\
\hline Other Micronesian & 386 & 450 & 0.2 \\
\hline Melanesian & 291 & 340 & 0.2 \\
\hline Pacific Islander, not specified & 354 & 413 & 0.2 \\
\hline Total Asian Population & 192,739 & 224,880 & 100.0 \\
\hline Total Population & $3,851,627$ & $4,164,437$ & - \\
\hline
\end{tabular}

* Projected

Appendix Table B-21. Asian market region 8, Boston, Ethnic detail.

\begin{tabular}{|c|c|c|c|}
\hline \multirow[b]{2}{*}{ Market Region Ethnic Subgroup } & \multicolumn{2}{|c|}{ Population } & \multirow{2}{*}{$\begin{array}{r}1994 \text { Percentage } \\
\text { distribution }\end{array}$} \\
\hline & 1990 & 1994* & \\
\hline Boston & (Number) & (Number) & (Percent) \\
\hline \multicolumn{4}{|l|}{ Asian or Pacific Islander: } \\
\hline Chinese & 57,085 & 67,212 & 34.6 \\
\hline Filipino & 9,785 & 11,521 & 5.9 \\
\hline Japanese & 10,057 & 11,841 & 6.1 \\
\hline Asian Indian & 22,095 & 26,015 & 13.4 \\
\hline Korean & 14,405 & 16,961 & 8.7 \\
\hline Vietnamese & 15,379 & 18,107 & 9.3 \\
\hline Cambodian & 17,849 & 21,016 & 10.8 \\
\hline Hmong & 1,273 & 1,499 & 0.8 \\
\hline Laotian & 6,551 & 7,713 & 4.0 \\
\hline Thai & 1,953 & 2,299 & 1.2 \\
\hline Other Asian & 6,810 & 8,018 & 4.1 \\
\hline \multicolumn{4}{|l|}{ Pacific Islander: } \\
\hline \multicolumn{4}{|l|}{ Polynesian: } \\
\hline Hawaiian & 714 & 841 & 0.4 \\
\hline Samoan & 194 & 228 & 0.1 \\
\hline Tongan & 25 & 29 & 0.0 \\
\hline Other Polynesian & 19 & 22 & 0.0 \\
\hline \multicolumn{4}{|l|}{ Micronesian: } \\
\hline Guamanian & 699 & 823 & 0.4 \\
\hline Other Micronesian & 23 & 27 & 0.0 \\
\hline Melanesian & 44 & 52 & 0.0 \\
\hline Pacific Islander, not specified & 94 & 111 & 0.1 \\
\hline Total Asian Population & 165,054 & 194,336 & 100.0 \\
\hline Total Population & $8,670,788$ & $8,824,607$ & -- \\
\hline
\end{tabular}


Appendix Table B-22. Asian market region 9, Houston, Ethnic detail.

\begin{tabular}{|c|c|c|c|}
\hline \multirow[b]{2}{*}{ Market Region Ethnic Subgroup } & \multicolumn{2}{|c|}{ Population } & \multirow{2}{*}{$\begin{array}{r}1994 \text { Percentage } \\
\text { distribution }\end{array}$} \\
\hline & 1990 & $1994^{*}$ & \\
\hline Houston & (Number) & (Number) & (Percent) \\
\hline \multicolumn{4}{|l|}{ Asian or Pacific Islander: } \\
\hline Chinese & 32,870 & 38,564 & 23.1 \\
\hline Filipino & 16,662 & 19,548 & 11.7 \\
\hline Japanese & 4,256 & 4,993 & 3.0 \\
\hline Asian Indian & 27,010 & 31,689 & 19.0 \\
\hline Korean & 8,060 & 9,456 & 5.7 \\
\hline Vietnamese & 38,173 & 44,786 & 26.8 \\
\hline Cambodian & 2,948 & 3,459 & 2.1 \\
\hline Hmong & 0 & 0 & 0.0 \\
\hline Laotian & 1,533 & 1,799 & 1.1 \\
\hline Thai & 1,791 & 2,101 & 1.3 \\
\hline Other Asian & 7,773 & 9,120 & 5.5 \\
\hline \multicolumn{4}{|l|}{ Pacific Islander: } \\
\hline \multicolumn{4}{|l|}{ Polynesian: } \\
\hline Hawaiian & 422 & 495 & 0.3 \\
\hline Samoan & 133 & 156 & 0.1 \\
\hline Tongan & 61 & 72 & 0.0 \\
\hline Other Polynesian & 36 & 42 & 0.0 \\
\hline \multicolumn{4}{|l|}{ Micronesian: } \\
\hline Guamanian & 541 & 635 & 0.4 \\
\hline Other Micronesian & 20 & 23 & 0.0 \\
\hline Melanesian & 48 & 56 & 0.0 \\
\hline Pacific Islander, not specified & 130 & 153 & 0.1 \\
\hline Total Asian Population & 142,467 & 167,147 & 100.0 \\
\hline Total Population & $4,615,085$ & $4,920,997$ & -- \\
\hline
\end{tabular}

* Projected

Appendix Table B-23. Asian market region 10, Philadelphia, Ethnic detail.

\begin{tabular}{|c|c|c|c|}
\hline \multirow[b]{2}{*}{ Market Region Ethnic Subgroup } & \multicolumn{2}{|c|}{ Population } & \multirow{2}{*}{$\begin{array}{r}1994 \text { Percentage } \\
\text { distribution }\end{array}$} \\
\hline & 1990 & $1994^{*}$ & \\
\hline & (Number) & (Number) & (Percent) \\
\hline \multicolumn{4}{|l|}{ Asian or Pacific Islander: } \\
\hline Chinese & 28,671 & 33,281 & 22.3 \\
\hline Filipino & 15,723 & 18,251 & 12.2 \\
\hline Japanese & 5,630 & 6,535 & 4.4 \\
\hline Asian Indian & 27,201 & 31,575 & 21.2 \\
\hline Korean & 25,002 & 29,022 & 19.5 \\
\hline Vietnamese & 10,460 & 12,142 & 8.1 \\
\hline Cambodian & 4,844 & 5,623 & 3.8 \\
\hline Hmong & 154 & 179 & 0.1 \\
\hline Laotian & 1,414 & 1,641 & 1.1 \\
\hline Thai & 1,077 & 1,250 & 0.8 \\
\hline Other Asian & 6,497 & 7,542 & 5.1 \\
\hline \multicolumn{4}{|l|}{ Pacific Islander: } \\
\hline \multicolumn{4}{|l|}{ Polynesian: } \\
\hline Hawaiian & 943 & 1,095 & 0.7 \\
\hline Samoan & 310 & 360 & 0.2 \\
\hline Tongan & 0 & 0 & 0.0 \\
\hline Other Polynesian & 12 & 14 & 0.0 \\
\hline \multicolumn{4}{|l|}{ Micronesian: } \\
\hline Guamanian & 386 & 448 & 0.3 \\
\hline Other Micronesian & 49 & 57 & 0.0 \\
\hline Melanesian & 10 & 12 & 0.0 \\
\hline Pacific Islander, not specified & 62 & 72 & 0.0 \\
\hline Total Asian Population & 128,445 & 149,098 & 100.0 \\
\hline Total Population & $6,329,754$ & $6,482,521$ & -- \\
\hline
\end{tabular}


Appendix Table B-24. Asian market region 11, Dallas, Ethnic detail.

\begin{tabular}{|c|c|c|c|}
\hline \multirow[b]{2}{*}{ Market Region Ethnic Subgroup } & \multicolumn{2}{|c|}{ Population } & \multirow{2}{*}{$\begin{array}{r}1994 \text { Percentage } \\
\text { distribution } \\
\end{array}$} \\
\hline & 1990 & $1994^{*}$ & \\
\hline Dallas & (Number) & (Number) & (Percent) \\
\hline \multicolumn{4}{|l|}{ Asian or Pacific Islander: } \\
\hline Chinese & 18,830 & 22,801 & 17.6 \\
\hline Filipino & 9,330 & 11,298 & 8.7 \\
\hline Japanese & 5,228 & 6,330 & 4.9 \\
\hline Asian Indian & 18,836 & 22,808 & 17.6 \\
\hline Korean & 12,343 & 14,946 & 11.5 \\
\hline Vietnamese & 20,565 & 24,902 & 19.2 \\
\hline Cambodian & 3,184 & 3,855 & 3.0 \\
\hline Hmong & 90 & 109 & 0.1 \\
\hline Laotian & 5,809 & 7,034 & 5.4 \\
\hline Thai & 3,038 & 3,679 & 2.8 \\
\hline Other Asian & 6,927 & 8,388 & 6.5 \\
\hline \multicolumn{4}{|l|}{ Pacific Islander: } \\
\hline \multicolumn{4}{|l|}{ Polynesian: } \\
\hline Hawaiian & 876 & 1,061 & 0.8 \\
\hline Samoan & 295 & 357 & 0.3 \\
\hline Tongan & 667 & 808 & 0.6 \\
\hline Other Polynesian & 198 & 240 & 0.2 \\
\hline \multicolumn{4}{|l|}{ Micronesian: } \\
\hline Guamanian & 434 & 526 & 0.4 \\
\hline Other Micronesian & 158 & 191 & 0.1 \\
\hline Melanesian & 62 & 75 & 0.1 \\
\hline Pacific Islander, not specified & 61 & 74 & 0.1 \\
\hline Total Asian Population & 106,931 & 129,481 & 100.0 \\
\hline Total Population & $6,370,102$ & $6,814,770$ & - \\
\hline
\end{tabular}

* Projected

Appendix Table B-25. Asian market region 12, Portland, Ethnic detail.

\begin{tabular}{|c|c|c|c|}
\hline \multirow[b]{2}{*}{ Market Region Ethnic Subgroup } & \multicolumn{2}{|c|}{ Population } & \multirow{2}{*}{$\begin{array}{r}1994 \text { Percentage } \\
\text { distribution }\end{array}$} \\
\hline & 1990 & $1994 *$ & \\
\hline Portland & (Number) & (Number) & (Percent) \\
\hline \multicolumn{4}{|l|}{ Asian or Pacific Islander: } \\
\hline Chinese & 14,706 & 17,673 & 19.1 \\
\hline Filipino & 8,203 & 9,858 & 10.6 \\
\hline Japanese & 12,739 & 15,309 & 16.5 \\
\hline Asian Indian & 3,754 & 4,511 & 4.9 \\
\hline Korean & 10,090 & 12,126 & 13.1 \\
\hline Vietnamese & 9,305 & 11,182 & 12.1 \\
\hline Cambodian & 2,964 & 3,562 & 3.8 \\
\hline Hmong & 1,226 & 1,473 & 1.6 \\
\hline Laotian & 4,056 & 4,874 & 5.3 \\
\hline Thai & 1,084 & 1,303 & 1.4 \\
\hline Other Asian & 3,245 & 3,900 & 4.2 \\
\hline \multicolumn{4}{|l|}{ Pacific Islander: } \\
\hline \multicolumn{4}{|l|}{ Polynesian: } \\
\hline Hawaiian & 2,851 & 3,426 & 3.7 \\
\hline Samoan & 528 & 635 & 0.7 \\
\hline Tongan & 150 & 180 & 0.2 \\
\hline Other Polynesian & 54 & 65 & 0.1 \\
\hline \multicolumn{4}{|l|}{ Micronesian: } \\
\hline Guamanian & 1,012 & 1,216 & 1.3 \\
\hline Other Micronesian & 681 & 818 & 0.9 \\
\hline Melanesian & 291 & 350 & 0.4 \\
\hline Pacific Islander, not specified & 204 & 245 & 0.3 \\
\hline Total Asian Population & 77,143 & 92,706 & 100.0 \\
\hline Total Population & $3,342,289$ & $3,562,058$ & -- \\
\hline
\end{tabular}


Appendix Table B-26. Asian market region 13, Minneapolis, Ethnic detail.

\begin{tabular}{|c|c|c|c|}
\hline \multirow[b]{2}{*}{ Market Region Ethnic Subgroup } & \multicolumn{2}{|c|}{ Population } & \multirow{2}{*}{$\begin{array}{r}1994 \text { Percentage } \\
\text { distribution }\end{array}$} \\
\hline & 1990 & $1994^{*}$ & \\
\hline Minneapolis & (Number) & (Number) & (Percent) \\
\hline \multicolumn{4}{|l|}{ Asian or Pacific Islander: } \\
\hline Chinese & 8,119 & 9,438 & 10.6 \\
\hline Filipino & 4,237 & 4,925 & 5.5 \\
\hline Japanese & 3,741 & 4,349 & 4.9 \\
\hline Asian Indian & 7,262 & 8,442 & 9.5 \\
\hline Korean & 12,065 & 14,025 & 15.7 \\
\hline Vietnamese & 9,439 & 10,972 & 12.3 \\
\hline Cambodian & 3,200 & 3,720 & 4.2 \\
\hline Hmong & 18,149 & 21,097 & 23.7 \\
\hline Laotian & 6,085 & 7,073 & 7.9 \\
\hline Thai & 552 & 642 & 0.7 \\
\hline Other Asian & 2,970 & 3,452 & 3.9 \\
\hline \multicolumn{4}{|l|}{ Pacific Islander: } \\
\hline \multicolumn{4}{|l|}{ Polynesian: } \\
\hline Hawaiian & 357 & 415 & 0.5 \\
\hline Samoan & 56 & 65 & 0.1 \\
\hline Tongan & 34 & 40 & 0.0 \\
\hline Other Polynesian & 2 & 2 & 0.0 \\
\hline \multicolumn{4}{|l|}{ Micronesian: } \\
\hline Guamanian & 141 & 164 & 0.2 \\
\hline Other Micronesian & 84 & 98 & 0.1 \\
\hline Melanesian & 0 & 0 & 0.0 \\
\hline Pacific Islander, not specified & 139 & 162 & 0.2 \\
\hline Total Asian Population & 76,632 & 89,079 & 100.0 \\
\hline Total Population & $4,291,261$ & $4,453,960$ & -- \\
\hline
\end{tabular}

* Projected

Appendix Table B-27. Asian market region 14, Detroit, Ethnic detail.

\begin{tabular}{|c|c|c|c|}
\hline \multirow[b]{2}{*}{ Market Region Ethnic Subgroup } & \multicolumn{2}{|c|}{ Population } & \multirow{2}{*}{$\begin{array}{r}1994 \text { Percentage } \\
\text { distribution }\end{array}$} \\
\hline & 1990 & $1994 *$ & \\
\hline Detroit & (Number) & (Number) & (Percent) \\
\hline \multicolumn{4}{|l|}{ Asian or Pacific Islander: } \\
\hline Chinese & 14,329 & 15,902 & 18.8 \\
\hline Filipino & 12,066 & 13,391 & 15.9 \\
\hline Japanese & 7,896 & 8,763 & 10.4 \\
\hline Asian Indian & 18,748 & 20,806 & 24.6 \\
\hline Korean & 11,011 & 12,220 & 14.5 \\
\hline Vietnamese & 2,230 & 2,475 & 2.9 \\
\hline Cambodian & 249 & 276 & 0.3 \\
\hline Hmong & 1,890 & 2,097 & 2.5 \\
\hline Laotian & 1,503 & 1,668 & 2.0 \\
\hline Thai & 915 & 1,015 & 1.2 \\
\hline Other Asian & 4,567 & 5,068 & 6.0 \\
\hline \multicolumn{4}{|l|}{ Pacific Islander: } \\
\hline \multicolumn{4}{|l|}{ Polynesian: } \\
\hline Hawaiian & 320 & 355 & 0.4 \\
\hline Samoan & 119 & 132 & 0.2 \\
\hline Tongan & 0 & 0 & 0.0 \\
\hline Other Polynesian & 0 & 0 & 0.0 \\
\hline \multicolumn{4}{|l|}{ Micronesian: } \\
\hline Guamanian & 124 & 138 & 0.2 \\
\hline Other Micronesian & 43 & 48 & 0.1 \\
\hline Melanesian & 5 & 6 & 0.0 \\
\hline Pacific Islander, not specified & 46 & 51 & 0.1 \\
\hline Total Asian Population & 76,061 & 84,411 & 100.0 \\
\hline Total Population & $6,351,802$ & $6,486,681$ & - - \\
\hline
\end{tabular}


Appendix Table B-28. Asian market region 15, Tampa, Ethnic detail.

\begin{tabular}{|c|c|c|c|}
\hline \multirow[b]{2}{*}{ Market Region Ethnic Subgroup } & \multicolumn{2}{|c|}{ Population } & \multirow{2}{*}{$\begin{array}{r}1994 \text { Percentage } \\
\text { distribution }\end{array}$} \\
\hline & 1990 & $1994^{*}$ & \\
\hline Tampa & (Number) & (Number) & (Percent) \\
\hline \multicolumn{4}{|l|}{ Asian or Pacific Islander: } \\
\hline Chinese & 10,337 & 13,302 & 16.7 \\
\hline Filipino & 11,556 & 14,871 & 18.7 \\
\hline Japanese & 4,025 & 5,179 & 6.5 \\
\hline Asian Indian & 11,442 & 14,724 & 18.5 \\
\hline Korean & 6,334 & 8,151 & 10.2 \\
\hline Vietnamese & 8,496 & 10,933 & 13.7 \\
\hline Cambodian & 494 & 636 & 0.8 \\
\hline Hmong & 0 & 0 & 0.0 \\
\hline Laotian & 1,769 & 2,276 & 2.9 \\
\hline Thai & 2,311 & 2,974 & 3.7 \\
\hline Other Asian & 2,994 & 3,853 & 4.8 \\
\hline \multicolumn{4}{|l|}{ Pacific Islander: } \\
\hline \multicolumn{4}{|l|}{ Polynesian: } \\
\hline Hawaiian & 1,049 & 1,350 & 1.7 \\
\hline Samoan & 273 & 351 & 0.4 \\
\hline Tongan & 150 & 193 & 0.2 \\
\hline Other Polynesian & 71 & 91 & 0.1 \\
\hline \multicolumn{4}{|l|}{ Micronesian: } \\
\hline Guamanian & 379 & 488 & 0.6 \\
\hline Other Micronesian & 38 & 49 & 0.1 \\
\hline Melanesian & 18 & 23 & 0.0 \\
\hline Pacific Islander, not specified & 62 & 80 & 0.1 \\
\hline Total Asian Population & 61,798 & 79,523 & 100.0 \\
\hline Total Population & $6,095,514$ & $6,633,584$ & -- \\
\hline
\end{tabular}

* Projected

Appendix Table B-29. Asian market region 16, Charlotte, Ethnic detail.

\begin{tabular}{|c|c|c|c|}
\hline \multirow[b]{2}{*}{ Market Region Ethnic Subgroup } & \multicolumn{2}{|c|}{ Population } & \multirow{2}{*}{$\begin{array}{r}1994 \text { Percentage } \\
\text { distribution }\end{array}$} \\
\hline & 1990 & 1994* & \\
\hline Charlotte & (Number) & (Number) & (Percent) \\
\hline \multicolumn{4}{|l|}{ Asian or Pacific Islander: } \\
\hline Chinese & 10,232 & 13,029 & 17.7 \\
\hline Filipino & 5,835 & 7,430 & 10.1 \\
\hline Japanese & 5,644 & 7,187 & 9.8 \\
\hline Asian Indian & 10,785 & 13,734 & 18.7 \\
\hline Korean & 8,030 & 10,225 & 13.9 \\
\hline Vietnamese & 5,543 & 7,058 & 9.6 \\
\hline Cambodian & 1,653 & 2,105 & 2.9 \\
\hline Hmong & 544 & 693 & 0.9 \\
\hline Laotian & 2,493 & 3,175 & 4.3 \\
\hline Thai & 1,410 & 1,796 & 2.4 \\
\hline Other Asian & 3,370 & 4,291 & 5.8 \\
\hline \multicolumn{4}{|l|}{ Pacific Islander: } \\
\hline \multicolumn{4}{|l|}{ Polynesian: } \\
\hline Hawaiian & 980 & 1,248 & 1.7 \\
\hline Samoan & 461 & 587 & 0.8 \\
\hline Tongan & 0 & 0 & 0.0 \\
\hline Other Polynesian & 49 & 62 & 0.1 \\
\hline \multicolumn{4}{|l|}{ Micronesian: } \\
\hline Guamanian & 592 & 754 & 1.0 \\
\hline Other Micronesian & 59 & 75 & 0.1 \\
\hline Melanesian & 0 & 0 & 0.0 \\
\hline Pacific Islander, not specified & 11 & 14 & 0.0 \\
\hline Total Asian Population & 57,691 & 73,464 & 100.0 \\
\hline Total Population & $7,684,248$ & $8,170,841$ & -- \\
\hline
\end{tabular}


Appendix Table B-30. Asian market region 17, Denver, Ethnic detail.

\begin{tabular}{|c|c|c|c|}
\hline \multirow[b]{2}{*}{ Market Region Ethnic Subgroup } & \multicolumn{2}{|c|}{ Population } & \multirow{2}{*}{$\begin{array}{r}1994 \text { Percentage } \\
\text { distribution }\end{array}$} \\
\hline & 1990 & 1994* & \\
\hline Denver & (Number) & (Number) & (Percent) \\
\hline \multicolumn{4}{|l|}{ Asian or Pacific Islander: } \\
\hline Chinese & 9,200 & 10,875 & 14.8 \\
\hline Filipino & 6,608 & 7,811 & 10.6 \\
\hline Japanese & 12,536 & 14,819 & 20.2 \\
\hline Asian Indian & 3,484 & 4,118 & 5.6 \\
\hline Korean & 11,547 & 13,650 & 18.6 \\
\hline Vietnamese & 7,281 & 8,607 & 11.7 \\
\hline Cambodian & 1,007 & 1,190 & 1.6 \\
\hline Hmong & 1,207 & 1,427 & 1.9 \\
\hline Laotian & 1,608 & 1,901 & 2.6 \\
\hline Thai & 1,449 & 1,713 & 2.3 \\
\hline Other Asian & 3,372 & 3,986 & 5.4 \\
\hline \multicolumn{4}{|l|}{ Pacific Islander: } \\
\hline \multicolumn{4}{|l|}{ Polynesian: } \\
\hline Hawaiian & 1,612 & 1,906 & 2.6 \\
\hline Samoan & 299 & 353 & 0.5 \\
\hline Tongan & 8 & 9 & 0.0 \\
\hline Other Polynesian & 43 & 51 & 0.1 \\
\hline \multicolumn{4}{|l|}{ Micronesian: } \\
\hline Guamanian & 682 & 806 & 1.1 \\
\hline Other Micronesian & 135 & 160 & 0.2 \\
\hline Melanesian & 30 & 35 & 0.0 \\
\hline Pacific Islander, not specified & 47 & 56 & 0.1 \\
\hline Total Asian Population & 62,155 & 73,473 & 100.0 \\
\hline Total Population & $3,625,555$ & $3,866,985$ & - \\
\hline
\end{tabular}

* Projected

Appendix Table B-31. Asian market region 18, Atlanta, Ethnic detail.

\begin{tabular}{|c|c|c|c|}
\hline \multirow[b]{2}{*}{ Market Region Ethnic Subgroup } & \multicolumn{2}{|c|}{ Population } & \multirow{2}{*}{$\begin{array}{r}1994 \text { Percentage } \\
\text { distribution }\end{array}$} \\
\hline & 1990 & $1994 *$ & \\
\hline Atlanta & (Number) & (Number) & (Percent) \\
\hline \multicolumn{4}{|l|}{ Asian or Pacific Islander: } \\
\hline Chinese & 11,802 & 14,868 & 20.4 \\
\hline Filipino & 3,756 & 4,732 & 6.5 \\
\hline Japanese & 5,039 & 6,348 & 8.7 \\
\hline Asian Indian & 10,404 & 13,107 & 18.0 \\
\hline Korean & 10,840 & 13,656 & 18.8 \\
\hline Vietnamese & 5,624 & 7,085 & 9.7 \\
\hline Cambodian & 1,710 & 2,154 & 3.0 \\
\hline Hmong & 377 & 475 & 0.7 \\
\hline Laotian & 2,975 & 3,748 & 5.2 \\
\hline Thai & 955 & 1,203 & 1.7 \\
\hline Other Asian & 3,352 & 4,223 & 5.8 \\
\hline \multicolumn{4}{|l|}{ Pacific Islander: } \\
\hline \multicolumn{4}{|l|}{ Polynesian: } \\
\hline Hawaiian & 408 & 514 & 0.7 \\
\hline Samoan & 92 & 116 & 0.2 \\
\hline Tongan & 0 & 0 & 0.0 \\
\hline Other Polynesian & 68 & 86 & 0.1 \\
\hline \multicolumn{4}{|l|}{ Micronesian: } \\
\hline Guamanian & 254 & 320 & 0.4 \\
\hline Other Micronesian & 17 & 21 & 0.0 \\
\hline Melanesian & 38 & 48 & 0.1 \\
\hline Pacific Islander, not specified & 21 & 26 & 0.0 \\
\hline Total Asian Population & 57,732 & 72,730 & 100.0 \\
\hline Total Population & $4,242,374$ & $4,545,594$ & - \\
\hline
\end{tabular}


Appendix Table B-32. Asian market region 19, Cincinnati, Ethnic detail.

\begin{tabular}{|c|c|c|c|}
\hline \multirow[b]{2}{*}{ Market Region Ethnic Subgroup } & \multicolumn{2}{|c|}{ Population } & \multirow{2}{*}{$\begin{array}{r}1994 \text { Percentage } \\
\text { distribution }\end{array}$} \\
\hline & 1990 & $1994^{*}$ & \\
\hline Cincinnati & (Number) & (Number) & (Percent) \\
\hline \multicolumn{4}{|l|}{ Asian or Pacific Islander: } \\
\hline Chinese & 12,467 & 14,767 & 20.4 \\
\hline Filipino & 6,639 & 7,864 & 10.9 \\
\hline Japanese & 7,812 & 9,253 & 12.8 \\
\hline Asian Indian & 13,680 & 16,204 & 22.4 \\
\hline Korean & 7,948 & 9,414 & 13.0 \\
\hline Vietnamese & 3,020 & 3,577 & 5.0 \\
\hline Cambodian & 1,881 & 2,228 & 3.1 \\
\hline Hmong & 0 & 0 & 0.0 \\
\hline Laotian & 1,612 & 1,909 & 2.6 \\
\hline Thai & 1,128 & 1,336 & 1.8 \\
\hline Other Asian & 3,889 & 4,606 & 6.4 \\
\hline \multicolumn{4}{|l|}{ Pacific Islander: } \\
\hline \multicolumn{4}{|l|}{ Polynesian: } \\
\hline Hawaiian & 457 & 541 & 0.7 \\
\hline Samoan & 120 & 142 & 0.2 \\
\hline Tongan & 0 & 0 & 0.0 \\
\hline Other Polynesian & 22 & 26 & 0.0 \\
\hline \multicolumn{4}{|l|}{ Micronesian: } \\
\hline Guamanian & 195 & 231 & 0.3 \\
\hline Other Micronesian & 43 & 51 & 0.1 \\
\hline Melanesian & 0 & 0 & 0.0 \\
\hline Pacific Islander, not specified & 80 & 95 & 0.1 \\
\hline Total Asian Population & 60,993 & 72,246 & 100.0 \\
\hline Total Population & $7,917,978$ & $8,027,315$ & -- \\
\hline
\end{tabular}

* Projected

Appendix Table B-33. Asian market region 20, Hartford, Ethnic detail.

\begin{tabular}{|c|c|c|c|}
\hline \multirow[b]{2}{*}{ Market Region Ethnic Subgroup } & \multicolumn{2}{|c|}{ Population } & \multirow{2}{*}{$\begin{array}{r}1994 \text { Percentage } \\
\text { distribution }\end{array}$} \\
\hline & 1990 & 1994* & \\
\hline Hartford & (Number) & (Number) & (Percent) \\
\hline \multicolumn{4}{|l|}{ Asian or Pacific Islander: } \\
\hline Chinese & 13,364 & 16,098 & 22.8 \\
\hline Filipino & 5,828 & 7,020 & 9.9 \\
\hline Japanese & 4,803 & 5,786 & 8.2 \\
\hline Asian Indian & 13,097 & 15,776 & 22.4 \\
\hline Korean & 6,251 & 7,530 & 10.7 \\
\hline Vietnamese & 4,995 & 6,017 & 8.5 \\
\hline Cambodian & 1,947 & 2,345 & 3.3 \\
\hline Hmong & 52 & 63 & 0.1 \\
\hline Laotian & 2,810 & 3,385 & 4.8 \\
\hline Thai & 656 & 790 & 1.1 \\
\hline Other Asian & 4,025 & 4,848 & 6.9 \\
\hline \multicolumn{4}{|l|}{ Pacific Islander: } \\
\hline \multicolumn{4}{|l|}{ Polynesian: } \\
\hline Hawaiian & 415 & 500 & 0.7 \\
\hline Samoan & 157 & 189 & 0.3 \\
\hline Tongan & 0 & 0 & 0.0 \\
\hline Other Polynesian & 0 & 0 & 0.0 \\
\hline \multicolumn{4}{|l|}{ Micronesian: } \\
\hline Guamanian & 161 & 194 & 0.3 \\
\hline Other Micronesian & 0 & 0 & 0.0 \\
\hline Melanesian & 11 & 13 & 0.0 \\
\hline Pacific Islander, not specified & 6 & 7 & 0.0 \\
\hline Total Asian Population & 58,578 & 70,562 & 100.0 \\
\hline Total Population & $4,099,438$ & $4,154,848$ & - \\
\hline
\end{tabular}


Appendix Table B-34. Asian market region 21, Miami, Ethnic detail.

\begin{tabular}{|c|c|c|c|}
\hline \multirow[b]{2}{*}{ Market Region Ethnic Subgroup } & \multicolumn{2}{|c|}{ Population } & \multirow{2}{*}{$\begin{array}{r}1994 \text { Percentage } \\
\text { distribution }\end{array}$} \\
\hline & 1990 & 1994* & \\
\hline Miami & (Number) & (Number) & (Percent) \\
\hline \multicolumn{4}{|l|}{ Asian or Pacific Islander: } \\
\hline Chinese & 15,724 & 20,355 & 29.5 \\
\hline Filipino & 7,920 & 10,253 & 14.9 \\
\hline Japanese & 2,906 & 3,762 & 5.4 \\
\hline Asian Indian & 13,807 & 17,874 & 25.9 \\
\hline Korean & 3,086 & 3,995 & 5.8 \\
\hline Vietnamese & 3,099 & 4,012 & 5.8 \\
\hline Cambodian & 109 & 141 & 0.2 \\
\hline \multicolumn{4}{|l|}{ Hmong } \\
\hline Laotian & 207 & 268 & 0.4 \\
\hline Thai & 1,425 & 1,845 & 2.7 \\
\hline Other Asian & 3,911 & 5,063 & 7.3 \\
\hline \multicolumn{4}{|l|}{ Pacific Islander: } \\
\hline \multicolumn{4}{|l|}{ Polynesian: } \\
\hline Hawaiian & 571 & 739 & 1.1 \\
\hline Samoan & 116 & 150 & 0.2 \\
\hline Tongan & 0 & 0 & 0.0 \\
\hline Other Polynesian & 36 & 47 & 0.1 \\
\hline Micronesian: & 0 & 0 & 0.0 \\
\hline Guamanian & 375 & 485 & 0.7 \\
\hline Other Micronesian & 9 & 12 & 0.0 \\
\hline Melanesian & 0 & 0 & 0.0 \\
\hline Pacific Islander, not specified & 24 & 31 & 0.0 \\
\hline Total Asian Population & 53,325 & 69,031 & 100.0 \\
\hline Total Population & $4,505,030$ & $4,935,707$ & -- \\
\hline
\end{tabular}

* Projected

Appendix Table B-35. Asian market region 22, Phoenix, Ethnic detail.

\begin{tabular}{|c|c|c|c|}
\hline \multirow[b]{2}{*}{ Market Region Ethnic Subgroup } & \multicolumn{2}{|c|}{ Population } & \multirow{2}{*}{$\begin{array}{r}1994 \text { Percentage } \\
\text { distribution }\end{array}$} \\
\hline & 1990 & 1994* & \\
\hline Phoenix & (Number) & (Number) & (Percent) \\
\hline \multicolumn{4}{|l|}{ Asian or Pacific Islander: } \\
\hline Chinese & 13,163 & 16,509 & 24.3 \\
\hline Filipino & 8,606 & 10,794 & 15.9 \\
\hline Japanese & 6,482 & 8,130 & 12.0 \\
\hline Asian Indian & 5,598 & 7,021 & 10.3 \\
\hline Korean & 6,541 & 8,204 & 12.1 \\
\hline Vietnamese & 4,588 & 5,754 & 8.5 \\
\hline Cambodian & 1,021 & 1,281 & 1.9 \\
\hline Hmong & 24 & 30 & 0.0 \\
\hline Laotian & 535 & 671 & 1.0 \\
\hline Thai & 1,382 & 1,733 & 2.6 \\
\hline Other Asian & 3,106 & 3,896 & 5.7 \\
\hline \multicolumn{4}{|l|}{ Pacific Islander: } \\
\hline \multicolumn{4}{|l|}{ Polynesian: } \\
\hline Hawaiian & 1,523 & 1,910 & 2.8 \\
\hline Samoan & 295 & 370 & 0.5 \\
\hline Tongan & 263 & 330 & 0.5 \\
\hline Other Polynesian & 98 & 123 & 0.2 \\
\hline \multicolumn{4}{|l|}{ Micronesian: } \\
\hline Guamanian & 570 & 715 & 1.1 \\
\hline Other Micronesian & 207 & 260 & 0.4 \\
\hline Melanesian & 10 & 13 & 0.0 \\
\hline Pacific Islander, not specified & 115 & 144 & 0.2 \\
\hline Total Asian Population & 54,127 & 67,888 & 100.0 \\
\hline Total Population & $3,665,228$ & $3,993,387$ & - \\
\hline
\end{tabular}


Appendix Table B-36. Asian market region 23, Richmond, Ethnic detail.

\begin{tabular}{|c|c|c|c|}
\hline \multirow[b]{2}{*}{ Market Region Ethnic Subgroup } & \multicolumn{2}{|c|}{ Population } & \multirow{2}{*}{$\begin{array}{r}1994 \text { Percentage } \\
\text { distribution }\end{array}$} \\
\hline & 1990 & $1994^{*}$ & \\
\hline Richmond & (Number) & (Number) & (Percent) \\
\hline \multicolumn{4}{|l|}{ Asian or Pacific Islander: } \\
\hline Chinese & 5,468 & 6,853 & 10.8 \\
\hline Filipino & 21,508 & 26,957 & 42.6 \\
\hline Japanese & 2,970 & 3,722 & 5.9 \\
\hline Asian Indian & 4,202 & 5,267 & 8.3 \\
\hline Korean & 5,938 & 7,442 & 11.8 \\
\hline Vietnamese & 4,176 & 5,234 & 8.3 \\
\hline Cambodian & 1,679 & 2,104 & 3.3 \\
\hline Hmong & 7 & 9 & 0.0 \\
\hline Laotian & 254 & 318 & 0.5 \\
\hline Thai & 715 & 896 & 1.4 \\
\hline Other Asian & 1,927 & 2,415 & 3.8 \\
\hline \multicolumn{4}{|l|}{ Pacific Islander: } \\
\hline \multicolumn{4}{|l|}{ Polynesian: } \\
\hline Hawaiian & 703 & 881 & 1.4 \\
\hline Samoan & 244 & 306 & 0.5 \\
\hline Tongan & 0 & 0 & 0.0 \\
\hline Other Polynesian & 23 & 29 & 0.0 \\
\hline \multicolumn{4}{|l|}{ Micronesian: } \\
\hline Guamanian & 549 & 688 & 1.1 \\
\hline Other Micronesian & 88 & 110 & 0.2 \\
\hline Melanesian & 0 & 0 & 0.0 \\
\hline Pacific Islander, not specified & 14 & 18 & 0.0 \\
\hline Total Asian Population & 50,465 & 63,251 & 100.0 \\
\hline Total Population & $3,252,069$ & $3,720,630$ & -- \\
\hline
\end{tabular}

* Projected

Appendix Table B-37. Asian market region 24, San Antonio, Ethnic detail.

\begin{tabular}{|c|c|c|c|}
\hline \multirow[b]{2}{*}{ Market Region Ethnic Subgroup } & \multicolumn{2}{|c|}{ Population } & \multirow{2}{*}{$\begin{array}{r}1994 \text { Percentage } \\
\text { distribution }\end{array}$} \\
\hline & 1990 & 1994* & \\
\hline San Antonio & (Number) & (Number) & (Percent) \\
\hline \multicolumn{4}{|l|}{ Asian or Pacific Islander: } \\
\hline Chinese & 9,747 & 11,784 & 19.2 \\
\hline Filipino & 7,906 & 9,558 & 15.6 \\
\hline Japanese & 4,170 & 5,042 & 8.2 \\
\hline Asian Indian & 6,632 & 8,018 & 13.1 \\
\hline Korean & 8,381 & 10,133 & 16.5 \\
\hline Vietnamese & 5,821 & 7,038 & 11.5 \\
\hline Cambodian & 228 & 276 & 0.4 \\
\hline Hmong & 0 & 0 & 0.0 \\
\hline Laotian & 796 & 962 & 1.6 \\
\hline Thai & 1,464 & 1,770 & 2.9 \\
\hline Other Asian & 2,974 & 3,596 & 5.9 \\
\hline \multicolumn{4}{|l|}{ Pacific Islander: } \\
\hline \multicolumn{4}{|l|}{ Polynesian: } \\
\hline Hawaiian & 1,042 & 1,260 & 2.1 \\
\hline Samoan & 188 & 227 & 0.4 \\
\hline Tongan & 0 & 0 & 0.0 \\
\hline Other Polynesian & 56 & 68 & 0.1 \\
\hline \multicolumn{4}{|l|}{ Micronesian: } \\
\hline Guamanian & 1,239 & 1,498 & 2.4 \\
\hline Other Micronesian & 93 & 112 & 0.2 \\
\hline Melanesian & 0 & 0 & 0.0 \\
\hline Pacific Islander, not specified & 39 & 47 & 0.1 \\
\hline Total Asian Population & 50,776 & 61,388 & 100.0 \\
\hline Total Population & $4,402,073$ & $4,722,173$ & - \\
\hline
\end{tabular}


Appendix Table B-38. Asian market region 25, Milwaukee, Ethnic detail.

\begin{tabular}{|c|c|c|c|}
\hline \multirow[b]{2}{*}{ Market Region Ethnic Subgroup } & \multicolumn{2}{|c|}{ Population } & \multirow{2}{*}{$\begin{array}{r}1994 \text { Percentage } \\
\text { distribution }\end{array}$} \\
\hline & 1990 & $1994^{*}$ & \\
\hline Milwaukee & (Number) & (Number) & (Percent) \\
\hline \multicolumn{4}{|l|}{ Asian or Pacific Islander: } \\
\hline Chinese & 7,568 & 8,683 & 14.2 \\
\hline Filipino & 4,167 & 4,781 & 7.8 \\
\hline Japanese & 2,807 & 3,220 & 5.3 \\
\hline Asian Indian & 6,416 & 7,361 & 12.0 \\
\hline Korean & 5,767 & 6,616 & 10.8 \\
\hline Vietnamese & 2,306 & 2,646 & 4.3 \\
\hline Cambodian & 455 & 522 & 0.9 \\
\hline Hmong & 16,549 & 18,987 & 31.1 \\
\hline Laotian & 3,363 & 3,858 & 6.3 \\
\hline Thai & 435 & 499 & 0.8 \\
\hline Other Asian & 2,707 & 3,106 & 5.1 \\
\hline \multicolumn{4}{|l|}{ Pacific Islander: } \\
\hline \multicolumn{4}{|l|}{ Polynesian: } \\
\hline Hawaiian & 354 & 406 & 0.7 \\
\hline Samoan & 60 & 69 & 0.1 \\
\hline Tongan & 9 & 10 & 0.0 \\
\hline Other Polynesian & 0 & 0 & 0.0 \\
\hline \multicolumn{4}{|l|}{ Micronesian: } \\
\hline Guamanian & 186 & 213 & 0.3 \\
\hline Other Micronesian & 49 & 56 & 0.1 \\
\hline Melanesian & 40 & 46 & 0.1 \\
\hline Pacific Islander, not specified & 30 & 34 & 0.1 \\
\hline Total Asian Population & 53,268 & 61,114 & 100.0 \\
\hline Total Population & $4,930,564$ & $5,092,849$ & - \\
\hline
\end{tabular}


Appendix Table B-39. Hispanic market region 1, Los Angeles, Ethnic detail.

\begin{tabular}{|c|c|c|c|}
\hline \multirow[b]{2}{*}{ Market Region Ethnic Subgroup } & \multicolumn{2}{|c|}{ Population } & \multirow{2}{*}{$\begin{array}{r}1994 \text { Percentage } \\
\text { distribution }\end{array}$} \\
\hline & 1990 & $1994 *$ & \\
\hline Los Angeles & (Number) & (Number) & (Percent) \\
\hline \multicolumn{4}{|l|}{ Hispanic origin: } \\
\hline Mexican & $4,540,794$ & $5,196,655$ & 80.5 \\
\hline Puerto Rican & 84,330 & 96,510 & 1.5 \\
\hline Cuban & 70,483 & 80,663 & 1.2 \\
\hline \multicolumn{4}{|l|}{ Other Hispanic: } \\
\hline Dominican (Dominican Republic) & 4,583 & 5,245 & 0.1 \\
\hline \multicolumn{4}{|l|}{ Central American: } \\
\hline Guatemalan & 144,206 & 165,035 & 2.6 \\
\hline Honduran & 26,925 & 30,814 & 0.5 \\
\hline Nicaraguan & 42,089 & 48,168 & 0.7 \\
\hline Panamanian & 9,698 & 11,099 & 0.2 \\
\hline Salvadoran & 281,327 & 321,961 & 5.0 \\
\hline Other Central American & 17,609 & 20,152 & 0.3 \\
\hline \multicolumn{4}{|l|}{ South American: } \\
\hline Colombian & 34,575 & 39,569 & 0.6 \\
\hline Ecuadorian & 24,572 & 28,121 & 0.4 \\
\hline Peruvian & 31,821 & 36,417 & 0.6 \\
\hline Other South American & 52,893 & 60,533 & 0.9 \\
\hline Other Hispanic & 276,282 & 316,187 & 4.9 \\
\hline Total Hispanic Population & $5,642,187$ & $6,457,130$ & 100.0 \\
\hline Total Population & $19,038,791$ & $20,695,929$ & -- \\
\hline
\end{tabular}

* Projected

Appendix Table B-40. Hispanic market region 2, New York, Ethnic detail.

\begin{tabular}{|c|c|c|c|}
\hline \multirow[b]{2}{*}{ Market Region Ethnic Subgroup } & \multicolumn{2}{|c|}{ Population } & \multirow{2}{*}{$\begin{array}{r}1994 \text { Percentage } \\
\text { distribution }\end{array}$} \\
\hline & 1990 & 1994* & \\
\hline New York & (Number) & (Number) & (Percent) \\
\hline \multicolumn{4}{|l|}{ Hispanic origin: } \\
\hline Mexican & 96,430 & 106,057 & 3.6 \\
\hline Puerto Rican & $1,202,215$ & $1,322,239$ & 45.4 \\
\hline Cuban & 156,868 & 172,529 & 5.9 \\
\hline \multicolumn{4}{|l|}{ Other Hispanic: } \\
\hline Dominican (Dominican Republic) & 404,412 & 444,787 & 15.3 \\
\hline \multicolumn{4}{|l|}{ Central American: } \\
\hline Guatemalan & 27,469 & 30,211 & 1.0 \\
\hline Honduran & 33,481 & 36,824 & 1.3 \\
\hline Nicaraguan & 13,899 & 15,287 & 0.5 \\
\hline Panamanian & 27,081 & 29,785 & 1.0 \\
\hline Salvadoran & 63,027 & 69,319 & 2.4 \\
\hline Other Central American & 13,348 & 14,681 & 0.5 \\
\hline \multicolumn{4}{|l|}{ South American: } \\
\hline Colombian & 154,273 & 169,675 & 5.8 \\
\hline Ecuadorian & 115,865 & 127,432 & 4.4 \\
\hline Peruvian & 55,115 & 60,617 & 2.1 \\
\hline Other South American & 67,880 & 74,657 & 2.6 \\
\hline Other Hispanic & 215,545 & 237,064 & 8.1 \\
\hline Total Hispanic Population & $2,646,908$ & $2,911,163$ & 100.0 \\
\hline Total Population & $17,504,762$ & $18,081,759$ & - \\
\hline
\end{tabular}

* Projected 
Appendix Table B-41. Hispanic market region 3, San Antonio, Ethnic detail.

\begin{tabular}{|c|c|c|c|}
\hline \multirow[b]{2}{*}{ Market Region Ethnic Subgroup } & \multicolumn{2}{|c|}{ Population } & \multirow{2}{*}{$\begin{array}{r}1994 \text { Percentage } \\
\text { distribution }\end{array}$} \\
\hline & 1990 & $1994^{*}$ & \\
\hline San Antonio & (Number) & (Number) & (Percent) \\
\hline \multicolumn{4}{|l|}{ Hispanic origin: } \\
\hline Mexican & $1,945,549$ & $2,129,648$ & 93.8 \\
\hline Puerto Rican & 18,413 & 20,155 & 0.9 \\
\hline Cuban & 3,724 & 4,076 & 0.2 \\
\hline \multicolumn{4}{|l|}{ Other Hispanic: } \\
\hline Dominican (Dominican Republic) & 867 & 949 & 0.0 \\
\hline \multicolumn{4}{|l|}{ Central American: } \\
\hline Guatemalan & 1,996 & 2,185 & 0.1 \\
\hline Honduran & 1,644 & 1,800 & 0.1 \\
\hline Nicaraguan & 1,947 & 2,131 & 0.1 \\
\hline Panamanian & 2,325 & 2,545 & 0.1 \\
\hline Salvadoran & 3,784 & 4,142 & 0.2 \\
\hline Other Central American & 604 & 661 & 0.0 \\
\hline \multicolumn{4}{|l|}{ South American: } \\
\hline Colombian & 2,072 & 2,268 & 0.1 \\
\hline Ecuadorian & 400 & 438 & 0.0 \\
\hline Peruvian & 990 & 1,084 & 0.0 \\
\hline Other South American & 2,844 & 3,113 & 0.1 \\
\hline Other Hispanic & 87,856 & 96,169 & 4.2 \\
\hline Total Hispanic Population & $2,075,015$ & $2,271,365$ & 100.0 \\
\hline Total Population & $4,402,073$ & $4,722,173$ & -- \\
\hline
\end{tabular}

* Projected

Appendix Table B-42. Hispanic market region 4, Albuquerque, Ethnic detail.

\begin{tabular}{|c|c|c|c|}
\hline \multirow[b]{2}{*}{ Market Region Ethnic Subgroup } & \multicolumn{2}{|c|}{ Population } & \multirow{2}{*}{$\begin{array}{r}1994 \text { Percentage } \\
\text { distribution }\end{array}$} \\
\hline & 1990 & 1994* & \\
\hline Albuquerque & (Number) & (Number) & (Percent) \\
\hline \multicolumn{4}{|l|}{ Hispanic origin: } \\
\hline Mexican & $1,050,864$ & $1,148,663$ & 78.0 \\
\hline Puerto Rican & 8,306 & 9,079 & 0.6 \\
\hline Cuban & 1,382 & 1,511 & 0.1 \\
\hline \multicolumn{4}{|l|}{ Other Hispanic: } \\
\hline Dominican (Dominican Republic) & 487 & 532 & 0.0 \\
\hline \multicolumn{4}{|l|}{ Central American: } \\
\hline Guatemalan & 1,215 & 1,328 & 0.1 \\
\hline Honduran & 421 & 460 & 0.0 \\
\hline Nicaraguan & 785 & 858 & 0.1 \\
\hline Panamanian & 1,233 & 1,348 & 0.1 \\
\hline Salvadoran & 1,010 & 1,104 & 0.1 \\
\hline Other Central American & 275 & 301 & 0.0 \\
\hline \multicolumn{4}{|l|}{ South American: } \\
\hline Colombian & 750 & 820 & 0.1 \\
\hline Ecuadorian & 288 & 315 & 0.0 \\
\hline Peruvian & 587 & 642 & 0.0 \\
\hline Other South American & 1,454 & 1,589 & 0.1 \\
\hline Other Hispanic & 278,612 & 304,541 & 20.7 \\
\hline Total Hispanic Population & $1,347,669$ & $1,473,091$ & 100.0 \\
\hline Total Population & $3,542,407$ & $3,738,809$ & - \\
\hline
\end{tabular}


Appendix Table B-43. Hispanic market region 5, San Francisco, Ethnic detail.

\begin{tabular}{|c|c|c|c|}
\hline \multirow[b]{2}{*}{ Market Region Ethnic Subgroup } & \multicolumn{2}{|c|}{ Population } & \multirow{2}{*}{$\begin{array}{r}1994 \text { Percentage } \\
\text { distribution }\end{array}$} \\
\hline & 1990 & $1994^{*}$ & \\
\hline San Francisco & (Number) & (Number) & (Percent) \\
\hline \multicolumn{4}{|l|}{ Hispanic origin: } \\
\hline Mexican & 854,419 & 975,251 & 70.6 \\
\hline Puerto Rican & 42,205 & 48,174 & 3.5 \\
\hline Cuban & 9,691 & 11,062 & 0.8 \\
\hline \multicolumn{4}{|l|}{ Other Hispanic: } \\
\hline Dominican (Dominican Republic) & 1,504 & 1,717 & 0.1 \\
\hline \multicolumn{4}{|l|}{ Central American: } \\
\hline Guatemalan & 14,331 & 16,358 & 1.2 \\
\hline Honduran & 2,831 & 3,231 & 0.2 \\
\hline Nicaraguan & 31,848 & 36,352 & 2.6 \\
\hline Panamanian & 3,745 & 4,275 & 0.3 \\
\hline Salvadoran & 55,774 & 63,662 & 4.6 \\
\hline Other Central American & 3,703 & 4,227 & 0.3 \\
\hline \multicolumn{4}{|l|}{ South American: } \\
\hline Colombian & 7,195 & 8,213 & 0.6 \\
\hline Ecuadorian & 2,363 & 2,697 & 0.2 \\
\hline Peruvian & 13,492 & 15,400 & 1.1 \\
\hline Other South American & 15,086 & 17,219 & 1.2 \\
\hline Other Hispanic & 151,232 & 172,619 & 12.5 \\
\hline Total Hispanic Population & $1,209,419$ & $1,380,455$ & 100.0 \\
\hline Total Population & $8,903,125$ & $9,520,380$ & - \\
\hline
\end{tabular}

* Projected

Appendix Table B-44. Hispanic market region 6, Miami, Ethnic detail.

\begin{tabular}{|c|c|c|c|}
\hline \multirow[b]{2}{*}{ Market Region Ethnic Subgroup } & \multicolumn{2}{|c|}{ Population } & \multirow{2}{*}{$\begin{array}{r}1994 \text { Percentage } \\
\text { distribution }\end{array}$} \\
\hline & 1990 & $1994 *$ & \\
\hline Miami & (Number) & (Number) & (Percent) \\
\hline \multicolumn{4}{|l|}{ Hispanic origin: } \\
\hline Mexican & 54,358 & 63,223 & 4.7 \\
\hline Puerto Rican & 110,574 & 128,607 & 9.7 \\
\hline Cuban & 611,524 & 711,253 & 53.4 \\
\hline \multicolumn{4}{|l|}{ Other Hispanic: } \\
\hline Dominican (Dominican Republic) & 28,270 & 32,880 & 2.5 \\
\hline \multicolumn{4}{|l|}{ Central American: } \\
\hline Guatemalan & 10,972 & 12,761 & 1.0 \\
\hline Honduran & 20,339 & 23,656 & 1.8 \\
\hline Nicaraguan & 76,977 & 89,531 & 6.7 \\
\hline Panamanian & 8,191 & 9,527 & 0.7 \\
\hline Salvadoran & 10,071 & 11,713 & 0.9 \\
\hline Other Central American & 5,844 & 6,797 & 0.5 \\
\hline \multicolumn{4}{|l|}{ South American: } \\
\hline Colombian & 69,859 & 81,252 & 6.1 \\
\hline Ecuadorian & 11,561 & 13,446 & 1.0 \\
\hline Peruvian & 21,417 & 24,910 & 1.9 \\
\hline Other South American & 39,384 & 45,807 & 3.4 \\
\hline Other Hispanic & 66,442 & 77,278 & 5.8 \\
\hline Total Hispanic Population & $1,145,783$ & $1,332,641$ & 100.0 \\
\hline Total Population & $4,505,030$ & $4,935,707$ & - \\
\hline
\end{tabular}

* Projected 
Appendix Table B-45. Hispanic market region 7, Chicago, Ethnic detail.

\begin{tabular}{|c|c|c|c|}
\hline \multirow[b]{2}{*}{ Market Region Ethnic Subgroup } & \multicolumn{2}{|c|}{ Population } & \multirow{2}{*}{$\begin{array}{r}1994 \text { Percentage } \\
\text { distribution }\end{array}$} \\
\hline & 1990 & $1994^{*}$ & \\
\hline Chicago & (Number) & (Number) & (Percent) \\
\hline \multicolumn{4}{|l|}{ Hispanic origin: } \\
\hline Mexican & 637,738 & 706,338 & 70.3 \\
\hline Puerto Rican & 154,946 & 171,613 & 17.1 \\
\hline Cuban & 17,323 & 19,186 & 1.9 \\
\hline \multicolumn{4}{|l|}{ Other Hispanic: } \\
\hline Dominican (Dominican Republic) & 2,198 & 2,434 & 0.2 \\
\hline \multicolumn{4}{|l|}{ Central American: } \\
\hline Guatemalan & 15,934 & 17,648 & 1.8 \\
\hline Honduran & 3,289 & 3,643 & 0.4 \\
\hline Nicaraguan & 1,324 & 1,466 & 0.1 \\
\hline Panamanian & 1,583 & 1,753 & 0.2 \\
\hline Salvadoran & 6,223 & 6,892 & 0.7 \\
\hline Other Central American & 1,312 & 1,453 & 0.1 \\
\hline \multicolumn{4}{|l|}{ South American: } \\
\hline Colombian & 9,997 & 11,072 & 1.1 \\
\hline Ecuadorian & 8,636 & 9,565 & 1.0 \\
\hline Peruvian & 4,462 & 4,942 & 0.5 \\
\hline Other South American & 7,032 & 7,788 & 0.8 \\
\hline Other Hispanic & 35,612 & 39,443 & 3.9 \\
\hline Total Hispanic Population & 907,609 & $1,005,239$ & 100.0 \\
\hline Total Population & $9,563,681$ & $9,855,287$ & -- \\
\hline
\end{tabular}

* Projected

Appendix Table B-46. Hispanic market region 8, Houston, Ethnic detail.

\begin{tabular}{|c|c|c|c|}
\hline \multirow[b]{2}{*}{ Market Region Ethnic Subgroup } & \multicolumn{2}{|c|}{ Population } & \multirow{2}{*}{$\begin{array}{r}1994 \text { Percentage } \\
\text { distribution }\end{array}$} \\
\hline & 1990 & $1994^{*}$ & \\
\hline Houston & (Number) & (Number) & (Percent) \\
\hline \multicolumn{4}{|l|}{ Hispanic origin: } \\
\hline Mexican & 693,238 & 788,032 & 82.5 \\
\hline Puerto Rican & 11,720 & 13,323 & 1.4 \\
\hline Cuban & 9,482 & 10,779 & 1.1 \\
\hline \multicolumn{4}{|l|}{ Other Hispanic: } \\
\hline Dominican (Dominican Republic) & 1,179 & 1,340 & 0.1 \\
\hline \multicolumn{4}{|l|}{ Central American: } \\
\hline Guatemalan & 6,344 & 7,211 & 0.8 \\
\hline Honduran & 6,365 & 7,235 & 0.8 \\
\hline Nicaraguan & 4,067 & 4,623 & 0.5 \\
\hline Panamanian & 1,355 & 1,540 & 0.2 \\
\hline Salvadoran & 41,516 & 47,193 & 4.9 \\
\hline Other Central American & 1,580 & 1,796 & 0.2 \\
\hline \multicolumn{4}{|l|}{ South American: } \\
\hline Colombian & 10,860 & 12,345 & 1.3 \\
\hline Ecuadorian & 1,935 & 2,200 & 0.2 \\
\hline Peruvian & 2,889 & 3,284 & 0.3 \\
\hline Other South American & 7,514 & 8,541 & 0.9 \\
\hline Other Hispanic & 39,790 & 45,231 & 4.7 \\
\hline Total Hispanic Population & 839,834 & 954,673 & 100.0 \\
\hline Total Population & $4,615,085$ & $4,920,997$ & - \\
\hline
\end{tabular}


Appendix Table B-47. Hispanic market region 9, Fresno, Ethnic detail.

\begin{tabular}{|c|c|c|c|}
\hline \multirow[b]{2}{*}{ Market Region Ethnic Subgroup } & \multicolumn{2}{|c|}{ Population } & \multirow{2}{*}{$\begin{array}{r}1994 \text { Percentage } \\
\text { distribution } \\
\end{array}$} \\
\hline & 1990 & $1994^{*}$ & \\
\hline Fresno & (Number) & (Number) & (Percent) \\
\hline \multicolumn{4}{|l|}{ Hispanic origin: } \\
\hline Mexican & 736,990 & 834,736 & 92.1 \\
\hline Puerto Rican & 9,462 & 10,717 & 1.2 \\
\hline Cuban & 1,261 & 1,428 & 0.2 \\
\hline \multicolumn{4}{|l|}{ Other Hispanic: } \\
\hline Dominican (Dominican Republic) & 254 & 288 & 0.0 \\
\hline \multicolumn{4}{|l|}{ Central American: } \\
\hline Guatemalan & 1,557 & 1,764 & 0.2 \\
\hline Honduran & 835 & 946 & 0.1 \\
\hline Nicaraguan & 1,333 & 1,510 & 0.2 \\
\hline Panamanian & 800 & 906 & 0.1 \\
\hline Salvadoran & 4,866 & 5,511 & 0.6 \\
\hline Other Central American & 595 & 674 & 0.1 \\
\hline \multicolumn{4}{|l|}{ South American: } \\
\hline Colombian & 993 & 1,125 & 0.1 \\
\hline Ecuadorian & 179 & 203 & 0.0 \\
\hline Peruvian & 972 & 1,101 & 0.1 \\
\hline Other South American & 1,596 & 1,808 & 0.2 \\
\hline Other Hispanic & 38,921 & 44,083 & 4.9 \\
\hline Total Hispanic Population & 800,614 & 906,798 & 100.0 \\
\hline Total Population & $2,685,636$ & $2,887,893$ & -- \\
\hline
\end{tabular}

* Projected

Appendix Table B-48. Hispanic market region 10, Phoenix, Ethnic detail.

\begin{tabular}{|c|c|c|c|}
\hline \multirow[b]{2}{*}{ Market Region Ethnic Subgroup } & \multicolumn{2}{|c|}{ Population } & \multirow{2}{*}{$\begin{array}{r}1994 \text { Percentage } \\
\text { distribution }\end{array}$} \\
\hline & 1990 & $1994 *$ & \\
\hline Phoenix & (Number) & (Number) & (Percent) \\
\hline \multicolumn{4}{|l|}{ Hispanic origin: } \\
\hline Mexican & 619,435 & 701,430 & 91.0 \\
\hline Puerto Rican & 8,516 & 9,643 & 1.3 \\
\hline Cuban & 2,435 & 2,757 & 0.4 \\
\hline \multicolumn{4}{|l|}{ Other Hispanic: } \\
\hline Dominican (Dominican Republic) & 302 & 342 & 0.0 \\
\hline \multicolumn{4}{|l|}{ Central American: } \\
\hline Guatemalan & 1,578 & 1,787 & 0.2 \\
\hline Honduran & 708 & 802 & 0.1 \\
\hline Nicaraguan & 695 & 787 & 0.1 \\
\hline Panamanian & 743 & 841 & 0.1 \\
\hline Salvadoran & 2,229 & 2,524 & 0.3 \\
\hline Other Central American & 548 & 621 & 0.1 \\
\hline \multicolumn{4}{|l|}{ South American: } \\
\hline Colombian & 1,556 & 1,762 & 0.2 \\
\hline Ecuadorian & 349 & 395 & 0.1 \\
\hline Peruvian & 915 & 1,036 & 0.1 \\
\hline Other South American & 2,313 & 2,619 & 0.3 \\
\hline Other Hispanic & 38,306 & 43,377 & 5.6 \\
\hline Total Hispanic Population & 680,628 & 770,724 & \\
\hline Total Population & $3,665,228$ & $3,993,387$ & 100.0 \\
\hline
\end{tabular}

* Projected 
Appendix Table B-49. Hispanic market region 11, Dallas, Ethnic detail.

\begin{tabular}{|c|c|c|c|}
\hline \multirow[b]{2}{*}{ Market Region Ethnic Subgroup } & \multicolumn{2}{|c|}{ Population } & \multirow{2}{*}{$\begin{array}{r}1994 \text { Percentage } \\
\text { distribution }\end{array}$} \\
\hline & 1990 & $1994^{*}$ & \\
\hline Dallas & (Number) & (Number) & (Percent) \\
\hline \multicolumn{4}{|l|}{ Hispanic origin: } \\
\hline Mexican & 549,753 & 646,981 & 87.1 \\
\hline Puerto Rican & 10,326 & 12,152 & 1.6 \\
\hline Cuban & 6,173 & 7,265 & 1.0 \\
\hline \multicolumn{4}{|l|}{ Other Hispanic: } \\
\hline Dominican (Dominican Republic) & 617 & 726 & 0.1 \\
\hline \multicolumn{4}{|l|}{ Central American: } \\
\hline Guatemalan & 2,877 & 3,386 & 0.5 \\
\hline Honduran & 2,360 & 2,777 & 0.4 \\
\hline Nicaraguan & 1,485 & 1,748 & 0.2 \\
\hline Panamanian & 1,278 & 1,504 & 0.2 \\
\hline Salvadoran & 12,324 & 14,504 & 2.0 \\
\hline Other Central American & 1,009 & 1,187 & 0.2 \\
\hline \multicolumn{4}{|l|}{ South American: } \\
\hline Colombian & 3,054 & 3,594 & 0.5 \\
\hline Ecuadorian & 969 & 1,140 & 0.2 \\
\hline Peruvian & 1,931 & 2,273 & 0.3 \\
\hline Other South American & 3,516 & 4,138 & 0.6 \\
\hline Other Hispanic & 33,509 & 39,435 & 5.3 \\
\hline Total Hispanic Population & 631,181 & 742,810 & 100.0 \\
\hline Total Population & $6,370,102$ & $6,814,770$ & - \\
\hline
\end{tabular}

* Projected

Appendix Table B-50. Hispanic market region 12, Denver, Ethnic detail.

\begin{tabular}{|c|c|c|c|}
\hline \multirow[b]{2}{*}{ Market Region Ethnic Subgroup } & \multicolumn{2}{|c|}{ Population } & \multirow{2}{*}{$\begin{array}{r}1994 \text { Percentage } \\
\text { distribution }\end{array}$} \\
\hline & 1990 & $1994 *$ & \\
\hline Denver & (Number) & (Number) & (Percent) \\
\hline \multicolumn{4}{|l|}{ Hispanic origin: } \\
\hline Mexican & 284,095 & 314,095 & 67.7 \\
\hline Puerto Rican & 7,539 & 8,335 & 1.8 \\
\hline Cuban & 2,206 & 2,439 & 0.5 \\
\hline \multicolumn{4}{|l|}{ Other Hispanic: } \\
\hline Dominican (Dominican Republic) & 479 & 530 & 0.1 \\
\hline \multicolumn{4}{|l|}{ Central American: } \\
\hline Guatemalan & 621 & 687 & 0.1 \\
\hline Honduran & 252 & 279 & 0.1 \\
\hline Nicaraguan & 231 & 255 & 0.1 \\
\hline Panamanian & 1,500 & 1,658 & 0.4 \\
\hline Salvadoran & 672 & 743 & 0.2 \\
\hline Other Central American & 433 & 479 & 0.1 \\
\hline \multicolumn{4}{|l|}{ South American: } \\
\hline Colombian & 1,042 & 1,152 & 0.2 \\
\hline Ecuadorian & 334 & 369 & 0.1 \\
\hline Peruvian & 1,364 & 1,508 & 0.3 \\
\hline Other South American & 2,228 & 2,463 & 0.5 \\
\hline Other Hispanic & 116,721 & 129,046 & 27.8 \\
\hline Total Hispanic Population & 419,717 & 464,038 & 100.0 \\
\hline Total Population & $3,625,555$ & $3,866,985$ & - \\
\hline
\end{tabular}

* Projected 
Appendix Table B-51. Hispanic market region 13, Tampa, Ethnic detail.

\begin{tabular}{|c|c|c|c|}
\hline \multirow[b]{2}{*}{ Market Region Ethnic Subgroup } & \multicolumn{2}{|c|}{ Population } & \multirow{2}{*}{$\begin{array}{r}1994 \text { Percentage } \\
\text { distribution }\end{array}$} \\
\hline & 1990 & $1994^{*}$ & \\
\hline Tampa & (Number) & (Number) & (Percent) \\
\hline \multicolumn{4}{|l|}{ Hispanic origin: } \\
\hline Mexican & 89,609 & 108,695 & 25.2 \\
\hline Puerto Rican & 116,075 & 140,797 & 32.7 \\
\hline Cuban & 56,712 & 68,791 & 16.0 \\
\hline \multicolumn{4}{|l|}{ Other Hispanic: } \\
\hline Dominican (Dominican Republic) & 5,277 & 6,401 & 1.5 \\
\hline \multicolumn{4}{|l|}{ Central American: } \\
\hline Guatemalan & 2,389 & 2,898 & 0.7 \\
\hline Honduran & 3,083 & 3,740 & 0.9 \\
\hline Nicaraguan & 1,676 & 2,033 & 0.5 \\
\hline Panamanian & 3,545 & 4,300 & 1.0 \\
\hline Salvadoran & 1,914 & 2,322 & 0.5 \\
\hline Other Central American & 1,573 & 1,908 & 0.4 \\
\hline \multicolumn{4}{|l|}{ South American: } \\
\hline Colombian & 11,719 & 14,215 & 3.3 \\
\hline Ecuadorian & 2,683 & 3,254 & 0.8 \\
\hline Peruvian & 2,894 & 3,510 & 0.8 \\
\hline Other South American & 6,462 & 7,838 & 1.8 \\
\hline Other Hispanic & 49,861 & 60,481 & 14.0 \\
\hline Total Hispanic Population & 355,472 & 431,183 & 100.0 \\
\hline Total Population & $6,095,514$ & $6,633,584$ & - \\
\hline
\end{tabular}

* Projected

Appendix Table B-52. Hispanic market region 14, Boston, Ethnic detail.

\begin{tabular}{|c|c|c|c|}
\hline \multirow[b]{2}{*}{ Market Region Ethnic Subgroup } & \multicolumn{2}{|c|}{ Population } & \multirow{2}{*}{$\begin{array}{r}1994 \text { Percentage } \\
\text { distribution }\end{array}$} \\
\hline & 1990 & $1994 *$ & \\
\hline Boston & (Number) & (Number) & (Percent) \\
\hline \multicolumn{4}{|l|}{ Hispanic origin: } \\
\hline Mexican & 18,952 & 21,400 & 6.6 \\
\hline Puerto Rican & 121,106 & 136,747 & 41.9 \\
\hline Cuban & 9,216 & 10,406 & 3.2 \\
\hline \multicolumn{4}{|l|}{ Other Hispanic: } \\
\hline Dominican (Dominican Republic) & 39,798 & 44,938 & 13.8 \\
\hline \multicolumn{4}{|l|}{ Central American: } \\
\hline Guatemalan & 11,180 & 12,624 & 3.9 \\
\hline Honduran & 3,852 & 4,349 & 1.3 \\
\hline Nicaraguan & 894 & 1,009 & 0.3 \\
\hline Panamanian & 1,742 & 1,967 & 0.6 \\
\hline Salvadoran & 10,304 & 11,635 & 3.6 \\
\hline Other Central American & 1,676 & 1,892 & 0.6 \\
\hline \multicolumn{4}{|l|}{ South American: } \\
\hline Colombian & 14,247 & 16,087 & 4.9 \\
\hline Ecuadorian & 2,758 & 3,114 & 1.0 \\
\hline Peruvian & 3,272 & 3,695 & 1.1 \\
\hline Other South American & 8,566 & 9,672 & 3.0 \\
\hline Other Hispanic & 41,601 & 46,974 & 14.4 \\
\hline Total Hispanic Population & 289,164 & 326,510 & 100.0 \\
\hline Total Population & $8,670,788$ & $8,824,607$ & - \\
\hline
\end{tabular}


Appendix Table B-53. Hispanic market region 15, Baltimore/Washington, Ethnic detail.

\begin{tabular}{|c|c|c|c|}
\hline \multirow[b]{2}{*}{ Market Region Ethnic Subgroup } & \multicolumn{2}{|c|}{ Population } & \multirow{2}{*}{$\begin{array}{r}1994 \text { Percentage } \\
\text { distribution }\end{array}$} \\
\hline & 1990 & $1994^{*}$ & \\
\hline Baltimore/Washington & (Number) & (Number) & (Percent) \\
\hline \multicolumn{4}{|l|}{ Hispanic origin: } \\
\hline Mexican & 33,111 & 41,871 & 14.0 \\
\hline Puerto Rican & 27,286 & 34,505 & 11.6 \\
\hline Cuban & 10,478 & 13,250 & 4.4 \\
\hline \multicolumn{4}{|l|}{ Other Hispanic: } \\
\hline Dominican (Dominican Republic) & 5,377 & 6,800 & 2.3 \\
\hline \multicolumn{4}{|l|}{ Central American: } \\
\hline Guatemalan & 9,491 & 12,002 & 4.0 \\
\hline Honduran & 3,532 & 4,466 & 1.5 \\
\hline Nicaraguan & 7,868 & 9,950 & 3.3 \\
\hline Panamanian & 4,428 & 5,600 & 1.9 \\
\hline Salvadoran & 48,037 & 60,747 & 20.4 \\
\hline Other Central American & 2,079 & 2,629 & 0.9 \\
\hline \multicolumn{4}{|l|}{ South American: } \\
\hline Colombian & 8,767 & 11,087 & 3.7 \\
\hline Ecuadorian & 4,931 & 6,236 & 2.1 \\
\hline Peruvian & 11,487 & 14,526 & 4.9 \\
\hline Other South American & 22,891 & 28,947 & 9.7 \\
\hline Other Hispanic & 36,088 & 45,636 & 15.3 \\
\hline Total Hispanic Population & 235,851 & 298,252 & 100.0 \\
\hline Total Population & $6,539,153$ & $7,101,236$ & - \\
\hline
\end{tabular}

* Projected

Appendix Table B-54. Hispanic market region 16, Hartford, Ethnic detail.

\begin{tabular}{|c|c|c|c|}
\hline \multirow[b]{2}{*}{ Market Region Ethnic Subgroup } & \multicolumn{2}{|c|}{ Population } & \multirow{2}{*}{$\begin{array}{r}1994 \text { Percentage } \\
\text { distribution }\end{array}$} \\
\hline & 1990 & $1994 *$ & \\
\hline Hartford & (Number) & (Number) & (Percent) \\
\hline \multicolumn{4}{|l|}{ Hispanic origin: } \\
\hline Mexican & 10,050 & 11,370 & 4.0 \\
\hline Puerto Rican & 182,240 & 206,179 & 71.9 \\
\hline Cuban & 6,777 & 7,667 & 2.7 \\
\hline \multicolumn{4}{|l|}{ Other Hispanic: } \\
\hline Dominican (Dominican Republic) & 4,570 & 5,170 & 1.8 \\
\hline \multicolumn{4}{|l|}{ Central American: } \\
\hline Guatemalan & 1,423 & 1,610 & 0.6 \\
\hline Honduran & 629 & 712 & 0.2 \\
\hline Nicaraguan & 468 & 529 & 0.2 \\
\hline Panamanian & 677 & 766 & 0.3 \\
\hline Salvadoran & 1,231 & 1,393 & 0.5 \\
\hline Other Central American & 1,281 & 1,449 & 0.5 \\
\hline \multicolumn{4}{|l|}{ South American: } \\
\hline Colombian & 8,059 & 9,118 & 3.2 \\
\hline Ecuadorian & 3,077 & 3,481 & 1.2 \\
\hline Peruvian & 4,433 & 5,015 & 1.7 \\
\hline Other South American & 4,957 & 5,608 & 2.0 \\
\hline Other Hispanic & 23,526 & 26,616 & 9.3 \\
\hline Total Hispanic Population & 253,398 & 286,685 & 100.0 \\
\hline Total Population & $4,099,438$ & $4,154,848$ & $\ldots$ \\
\hline
\end{tabular}


Appendix Table B-55. Hispanic market region 17, Philadelphia, Ethnic detail.

\begin{tabular}{|c|c|c|c|}
\hline \multirow[b]{2}{*}{ Market Region Ethnic Subgroup } & \multicolumn{2}{|c|}{ Population } & \multirow{2}{*}{$\begin{array}{r}1994 \text { Percentage } \\
\text { distribution }\end{array}$} \\
\hline & 1990 & $1994^{*}$ & \\
\hline Philadelphia & (Number) & (Number) & (Percent) \\
\hline \multicolumn{4}{|l|}{ Hispanic origin: } \\
\hline Mexican & 16,157 & 18,359 & 6.9 \\
\hline Puerto Rican & 163,385 & 185,653 & 69.9 \\
\hline Cuban & 8,321 & 9,455 & 3.6 \\
\hline \multicolumn{4}{|l|}{ Other Hispanic: } \\
\hline Dominican (Dominican Republic) & 4,196 & 4,768 & 1.8 \\
\hline \multicolumn{4}{|l|}{ Central American: } \\
\hline Guatemalan & 1,816 & 2,064 & 0.8 \\
\hline Honduran & 687 & 781 & 0.3 \\
\hline Nicaraguan & 1,433 & 1,628 & 0.6 \\
\hline Panamanian & 2,026 & 2,302 & 0.9 \\
\hline Salvadoran & 1,054 & 1,198 & 0.5 \\
\hline Other Central American & 1,212 & 1,377 & 0.5 \\
\hline \multicolumn{4}{|l|}{ South American: } \\
\hline Colombian & 5,534 & 6,288 & 2.4 \\
\hline Ecuadorian & 1,334 & 1,516 & 0.6 \\
\hline Peruvian & 1,188 & 1,350 & 0.5 \\
\hline Other South American & 4,428 & 5,032 & 1.9 \\
\hline Other Hispanic & 21,133 & 24,013 & 9.0 \\
\hline Total Hispanic Population & 233,904 & 265,783 & 100.0 \\
\hline Total Population & $6,329,754$ & $6,482,521$ & -- \\
\hline
\end{tabular}

* Projected

Appendix Table B-56. Hispanic market region 18, Seattle, Ethnic detail.

\begin{tabular}{|c|c|c|c|}
\hline \multirow[b]{2}{*}{ Market Region Ethnic Subgroup } & \multicolumn{2}{|c|}{ Population } & \multirow{2}{*}{$\begin{array}{r}1994 \text { Percentage } \\
\text { distribution }\end{array}$} \\
\hline & 1990 & $1994^{*}$ & \\
\hline Seattle & (Number) & (Number) & (Percent) \\
\hline \multicolumn{4}{|l|}{ Hispanic origin: } \\
\hline Mexican & 111,618 & 133,307 & 71.1 \\
\hline Puerto Rican & 8,015 & 9,572 & 5.1 \\
\hline Cuban & 1,966 & 2,348 & 1.3 \\
\hline \multicolumn{4}{|l|}{ Other Hispanic: } \\
\hline Dominican (Dominican Republic) & 350 & 418 & 0.2 \\
\hline \multicolumn{4}{|l|}{ Central American: } \\
\hline Guatemalan & 409 & 488 & 0.3 \\
\hline Honduran & 308 & 368 & 0.2 \\
\hline Nicaraguan & 682 & 815 & 0.4 \\
\hline Panamanian & 1,084 & 1,295 & 0.7 \\
\hline Salvadoran & 1,214 & 1,450 & 0.8 \\
\hline Other Central American & 337 & 402 & 0.2 \\
\hline \multicolumn{4}{|l|}{ South American: } \\
\hline Colombian & 1,195 & 1,427 & 0.8 \\
\hline Ecuadorian & 312 & 373 & 0.2 \\
\hline Peruvian & 1,144 & 1,366 & 0.7 \\
\hline Other South American & 2,700 & 3,225 & 1.7 \\
\hline Other Hispanic & 25,576 & 30,546 & 16.3 \\
\hline Total Hispanic Population & 156,910 & 187,400 & 100.0 \\
\hline Total Population & $3,851,627$ & $4,164,437$ & - \\
\hline
\end{tabular}


Appendix Table B-57. Hispanic market region 19, Salt Lake City, Ethnic detail.

\begin{tabular}{|c|c|c|c|}
\hline \multirow[b]{2}{*}{ Market Region Ethnic Subgroup } & \multicolumn{2}{|c|}{ Population } & \multirow{2}{*}{$\begin{array}{r}1994 \text { Percentage } \\
\text { distribution }\end{array}$} \\
\hline & 1990 & $1994^{*}$ & \\
\hline Salt Lake City & (Number) & (Number) & (Percent) \\
\hline \multicolumn{4}{|l|}{ Hispanic origin: } \\
\hline Mexican & 112,918 & 128,887 & 74.7 \\
\hline Puerto Rican & 2,754 & 3,143 & 1.8 \\
\hline Cuban & 668 & 762 & 0.4 \\
\hline \multicolumn{4}{|l|}{ Other Hispanic: } \\
\hline Dominican (Dominican Republic) & 146 & 167 & 0.1 \\
\hline \multicolumn{4}{|l|}{ Central American: } \\
\hline Guatemalan & 843 & 962 & 0.6 \\
\hline Honduran & 264 & 301 & 0.2 \\
\hline Nicaraguan & 306 & 349 & 0.2 \\
\hline Panamanian & 344 & 393 & 0.2 \\
\hline Salvadoran & 969 & 1,106 & 0.6 \\
\hline Other Central American & 359 & 410 & 0.2 \\
\hline \multicolumn{4}{|l|}{ South American: } \\
\hline Colombian & 879 & 1,003 & 0.6 \\
\hline Ecuadorian & 200 & 228 & 0.1 \\
\hline Peruvian & 1,152 & 1,315 & 0.8 \\
\hline Other South American & 2,358 & 2,691 & 1.6 \\
\hline Other Hispanic & 26,964 & 30,777 & 17.8 \\
\hline Total Hispanic Population & 151,124 & 172,497 & 100.0 \\
\hline Total Population & $2,718,444$ & $2,923,670$ & -- \\
\hline
\end{tabular}

* Projected

Appendix Table B-58. Hispanic market region 20, Portland, Ethnic detail.

\begin{tabular}{|c|c|c|c|}
\hline \multirow[b]{2}{*}{ Market Region Ethnic Subgroup } & \multicolumn{2}{|c|}{ Population } & \multirow{2}{*}{$\begin{array}{r}1994 \text { Percentage } \\
\text { distribution }\end{array}$} \\
\hline & 1990 & 1994* & \\
\hline Portland & (Number) & (Number) & (Percent) \\
\hline \multicolumn{4}{|l|}{ Hispanic origin: } \\
\hline Mexican & 93,107 & 110,050 & 75.4 \\
\hline Puerto Rican & 3,396 & 4,014 & 2.7 \\
\hline Cuban & 1,527 & 1,805 & 1.2 \\
\hline \multicolumn{4}{|l|}{ Other Hispanic: } \\
\hline Dominican (Dominican Republic) & 82 & 97 & 0.1 \\
\hline \multicolumn{4}{|l|}{ Central American: } \\
\hline Guatemalan & 1,262 & 1,492 & 1.0 \\
\hline Honduran & 500 & 591 & 0.4 \\
\hline Nicaraguan & 443 & 524 & 0.4 \\
\hline Panamanian & 392 & 463 & 0.3 \\
\hline Salvadoran & 927 & 1,096 & 0.8 \\
\hline Other Central American & 458 & 541 & 0.4 \\
\hline \multicolumn{4}{|l|}{ South American: } \\
\hline Colombian & 901 & 1,065 & 0.7 \\
\hline Ecuadorian & 256 & 303 & 0.2 \\
\hline Peruvian & 816 & 964 & 0.7 \\
\hline Other South American & 1,484 & 1,754 & 1.2 \\
\hline Other Hispanic & 18,009 & 21,286 & 14.6 \\
\hline Total Hispanic Population & 123,560 & 146,044 & 100.0 \\
\hline Total Population & $3,342,289$ & $3,562,058$ & - \\
\hline
\end{tabular}


Appendix Table B-59. Hispanic market region 21, Detroit, Ethnic detail.

\begin{tabular}{|c|c|c|c|}
\hline \multirow[b]{2}{*}{ Market Region Ethnic Subgroup } & \multicolumn{2}{|c|}{ Population } & \multirow{2}{*}{$\begin{array}{r}1994 \text { Percentage } \\
\text { distribution }\end{array}$} \\
\hline & 1990 & $1994^{*}$ & \\
\hline Detroit & (Number) & (Number) & (Percent) \\
\hline \multicolumn{4}{|l|}{ Hispanic origin: } \\
\hline Mexican & 86,446 & 98,994 & 69.4 \\
\hline Puerto Rican & 11,890 & 13,616 & 9.5 \\
\hline Cuban & 2,836 & 3,248 & 2.3 \\
\hline \multicolumn{4}{|l|}{ Other Hispanic: } \\
\hline Dominican (Dominican Republic) & 484 & 554 & 0.4 \\
\hline \multicolumn{4}{|l|}{ Central American: } \\
\hline Guatemalan & 331 & 379 & 0.3 \\
\hline Honduran & 268 & 307 & 0.2 \\
\hline Nicaraguan & 218 & 250 & 0.2 \\
\hline Panamanian & 405 & 464 & 0.3 \\
\hline Salvadoran & 360 & 412 & 0.3 \\
\hline Other Central American & 354 & 405 & 0.3 \\
\hline \multicolumn{4}{|l|}{ South American: } \\
\hline Colombian & 1,227 & 1,405 & 1.0 \\
\hline Ecuadorian & 400 & 458 & 0.3 \\
\hline Peruvian & 471 & 539 & 0.4 \\
\hline Other South American & 2,112 & 2,419 & 1.7 \\
\hline Other Hispanic & 16,816 & 19,257 & 13.5 \\
\hline Total Hispanic Population & 124,618 & 142,707 & 100.0 \\
\hline Total Population & $6,351,802$ & $6,486,681$ & -- \\
\hline
\end{tabular}

* Projected

Appendix Table B-60. Hispanic market region 22, Kansas City, Ethnic detail.

\begin{tabular}{|c|c|c|c|}
\hline \multirow[b]{2}{*}{ Market Region Ethnic Subgroup } & \multicolumn{2}{|c|}{ Population } & \multirow{2}{*}{$\begin{array}{r}1994 \text { Percentage } \\
\text { distribution }\end{array}$} \\
\hline & 1990 & $1994 *$ & \\
\hline Kansas City & (Number) & (Number) & (Percent) \\
\hline \multicolumn{4}{|l|}{ Hispanic origin: } \\
\hline Mexican & 98,258 & 109,636 & 80.9 \\
\hline Puerto Rican & 4,178 & 4,662 & 3.4 \\
\hline Cuban & 2,373 & 2,648 & 2.0 \\
\hline \multicolumn{4}{|l|}{ Other Hispanic: } \\
\hline Dominican (Dominican Republic) & 201 & 224 & 0.2 \\
\hline \multicolumn{4}{|l|}{ Central American: } \\
\hline Guatemalan & 487 & 543 & 0.4 \\
\hline Honduran & 379 & 423 & 0.3 \\
\hline Nicaraguan & 293 & 327 & 0.2 \\
\hline Panamanian & 736 & 821 & 0.6 \\
\hline Salvadoran & 419 & 468 & 0.3 \\
\hline Other Central American & 235 & 262 & 0.2 \\
\hline \multicolumn{4}{|l|}{ South American: } \\
\hline Colombian & 939 & 1,048 & 0.8 \\
\hline Ecuadorian & 608 & 678 & 0.5 \\
\hline Peruvian & 444 & 495 & 0.4 \\
\hline Other South American & 1,199 & 1,338 & 1.0 \\
\hline Other Hispanic & 10,728 & 11,970 & 8.8 \\
\hline Total Hispanic Population & 121,477 & 135,544 & 100.0 \\
\hline Total Population & $4,082,232$ & $4,235,744$ & - \\
\hline
\end{tabular}


Appendix Table B-61. Hispanic market region 23, Milwaukee, Ethnic detail.

\begin{tabular}{|c|c|c|c|}
\hline \multirow[b]{2}{*}{ Market Region Ethnic Subgroup } & \multicolumn{2}{|c|}{ Population } & \multirow{2}{*}{$\begin{array}{r}1994 \text { Percentage } \\
\text { distribution }\end{array}$} \\
\hline & 1990 & $1994 *$ & \\
\hline Milwaukee & (Number) & (Number) & (Percent) \\
\hline \multicolumn{4}{|l|}{ Hispanic origin: } \\
\hline Mexican & 57,238 & 66,171 & 65.0 \\
\hline Puerto Rican & 17,981 & 20,787 & 20.4 \\
\hline Cuban & 1,504 & 1,739 & 1.7 \\
\hline \multicolumn{4}{|l|}{ Other Hispanic: } \\
\hline Dominican (Dominican Republic) & 331 & 383 & 0.4 \\
\hline \multicolumn{4}{|l|}{ Central American: } \\
\hline Guatemalan & 225 & 260 & 0.3 \\
\hline Honduran & 168 & 194 & 0.2 \\
\hline Nicaraguan & 488 & 564 & 0.6 \\
\hline Panamanian & 287 & 332 & 0.3 \\
\hline Salvadoran & 322 & 372 & 0.4 \\
\hline Other Central American & 427 & 494 & 0.5 \\
\hline \multicolumn{4}{|l|}{ South American: } \\
\hline Colombian & 938 & 1,084 & 1.1 \\
\hline Ecuadorian & 108 & 125 & 0.1 \\
\hline Peruvian & 318 & 368 & 0.4 \\
\hline Other South American & 936 & 1,082 & 1.1 \\
\hline Other Hispanic & 6,835 & 7,902 & 7.8 \\
\hline Total Hispanic Population & 88,106 & 101,857 & 100.0 \\
\hline Total Population & $4,930,564$ & $5,092,849$ & - \\
\hline
\end{tabular}

* Projected

Appendix Table B-62. Hispanic market region 24, Scranton/Harrisburg, Ethnic detail.

\begin{tabular}{|c|c|c|c|}
\hline \multirow[b]{2}{*}{ Market Region Ethnic Subgroup } & \multicolumn{2}{|c|}{ Population } & \multirow{2}{*}{$\begin{array}{r}1994 \text { Percentage } \\
\text { distribution }\end{array}$} \\
\hline & 1990 & $1994 *$ & \\
\hline Scranton/Harrisburg & (Number) & (Number) & (Percent) \\
\hline \multicolumn{4}{|l|}{ Hispanic origin: } \\
\hline Mexican & 8,684 & 9,894 & 10.1 \\
\hline Puerto Rican & 59,219 & 67,470 & 68.7 \\
\hline Cuban & 2,207 & 2,515 & 2.6 \\
\hline \multicolumn{4}{|l|}{ Other Hispanic: } \\
\hline Dominican (Dominican Republic) & 1,697 & 1,933 & 2.0 \\
\hline \multicolumn{4}{|l|}{ Central American: } \\
\hline Guatemalan & 511 & 582 & 0.6 \\
\hline Honduran & 376 & 428 & 0.4 \\
\hline Nicaraguan & 296 & 337 & 0.3 \\
\hline Panamanian & 337 & 384 & 0.4 \\
\hline Salvadoran & 459 & 523 & 0.5 \\
\hline Other Central American & 179 & 204 & 0.2 \\
\hline \multicolumn{4}{|l|}{ South American: } \\
\hline Colombian & 2,032 & 2,315 & 2.4 \\
\hline Ecuadorian & 639 & 728 & 0.7 \\
\hline Peruvian & 606 & 690 & 0.7 \\
\hline Other South American & 935 & 1,065 & 1.1 \\
\hline Other Hispanic & 8,044 & 9,165 & 9.3 \\
\hline Total Hispanic Population & 86,221 & 98,234 & 100.0 \\
\hline Total Population & $4,332,674$ & $4,465,188$ & -- \\
\hline
\end{tabular}


Appendix Table B-63. Hispanic market region 25, Oklahoma City, Ethnic detail.

\begin{tabular}{|c|c|c|c|}
\hline \multirow[b]{2}{*}{ Market Region Ethnic Subgroup } & \multicolumn{2}{|c|}{ Population } & \multirow{2}{*}{$\begin{array}{c}1994 \text { Percentage } \\
\text { distribution }\end{array}$} \\
\hline & 1990 & $1994 *$ & \\
\hline Oklahoma City & (Number) & (Number) & (Percent) \\
\hline \multicolumn{4}{|l|}{ Hispanic origin: } \\
\hline Mexican & 59,073 & 67,048 & 74.6 \\
\hline Puerto Rican & 4,668 & 5,298 & 5.9 \\
\hline Cuban & 1,060 & 1,203 & 1.3 \\
\hline \multicolumn{4}{|l|}{ Other Hispanic: } \\
\hline Dominican (Dominican Republic) & 151 & 171 & 0.2 \\
\hline \multicolumn{4}{|l|}{ Central American: } \\
\hline Guatemalan & 355 & 403 & 0.4 \\
\hline Honduran & 334 & 379 & 0.4 \\
\hline Nicaraguan & 124 & 141 & 0.2 \\
\hline Panamanian & 719 & 816 & 0.9 \\
\hline Salvadoran & 402 & 456 & 0.5 \\
\hline Other Central American & 195 & 221 & 0.2 \\
\hline \multicolumn{4}{|l|}{ South American: } \\
\hline Colombian & 912 & 1,035 & 1.2 \\
\hline Ecuadorian & 113 & 128 & 0.1 \\
\hline Peruvian & 517 & 587 & 0.7 \\
\hline Other South American & 915 & 1,039 & 1.2 \\
\hline Other Hispanic & 9,654 & 10,957 & 12.2 \\
\hline Total Hispanic Population & 79,192 & 89,884 & 100.0 \\
\hline Total Population & $2,908,009$ & $2,996,124$ & - \\
\hline
\end{tabular}

* Projected 
Appendix Table B-64. Calendar of fruit availability and Asian holidays.

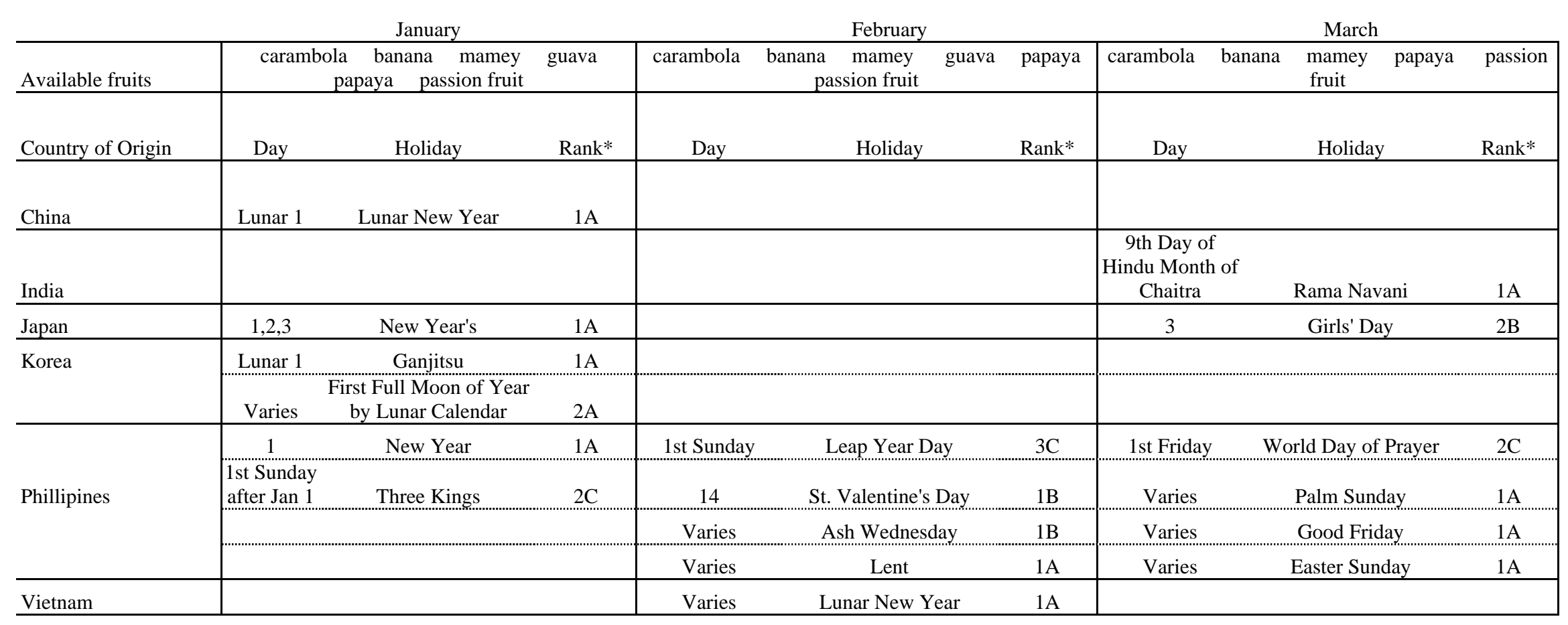

* The numeric portion of the ranking indicates the importance of the holiday: $1=$ very important holiday, $2=$ moderately important holiday and $3=$ minor holiday. Likewise the alphabetic portion of the rank indicates the significance of food in celebrating th 
Appendix Table B-64. Calendar of fruit availability and Asian holidays, continued.

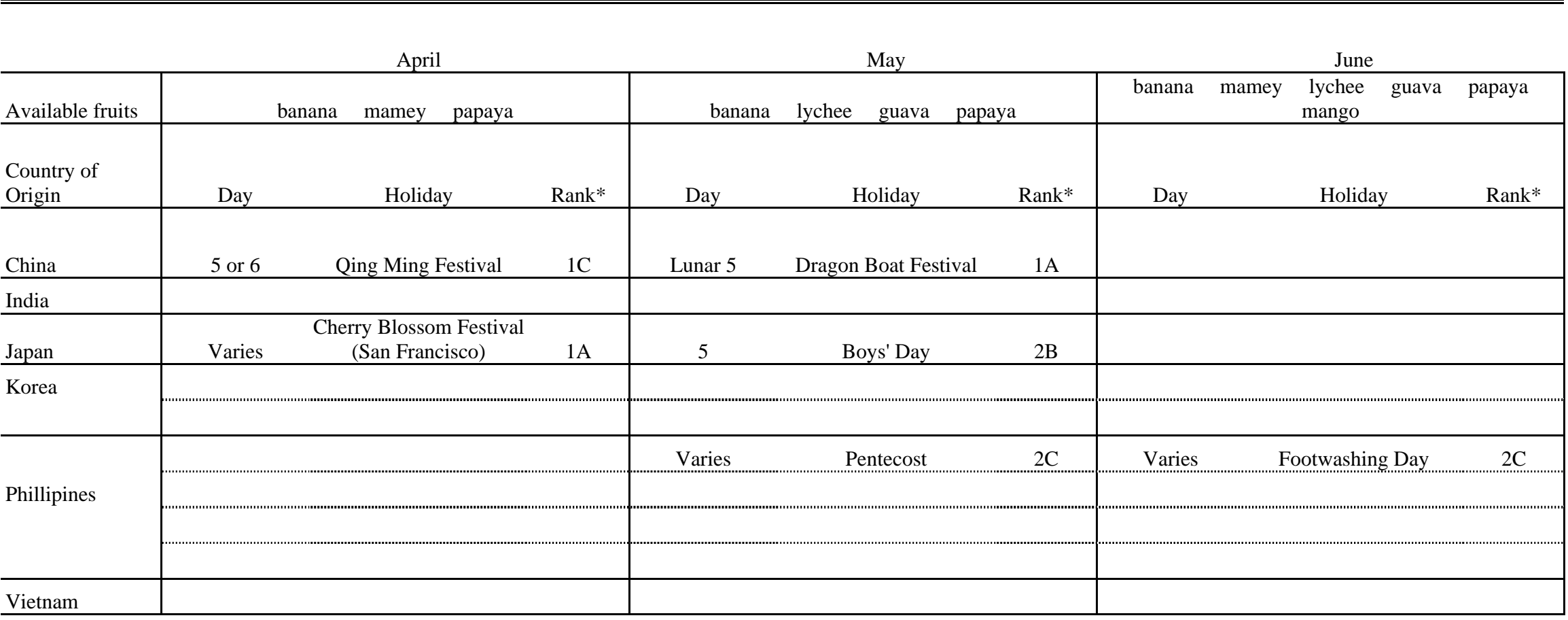

* The numeric portion of the ranking indicates the importance of the holiday: $1=$ =very important holiday, $2=$ moderately important holiday and $3=$ =minor holiday. Likewise the alphabetic portion of the rank indicates the significance of food in celebrating th 
Appendix Table B-64. Calendar of fruit availability and Asian holidays, continued.

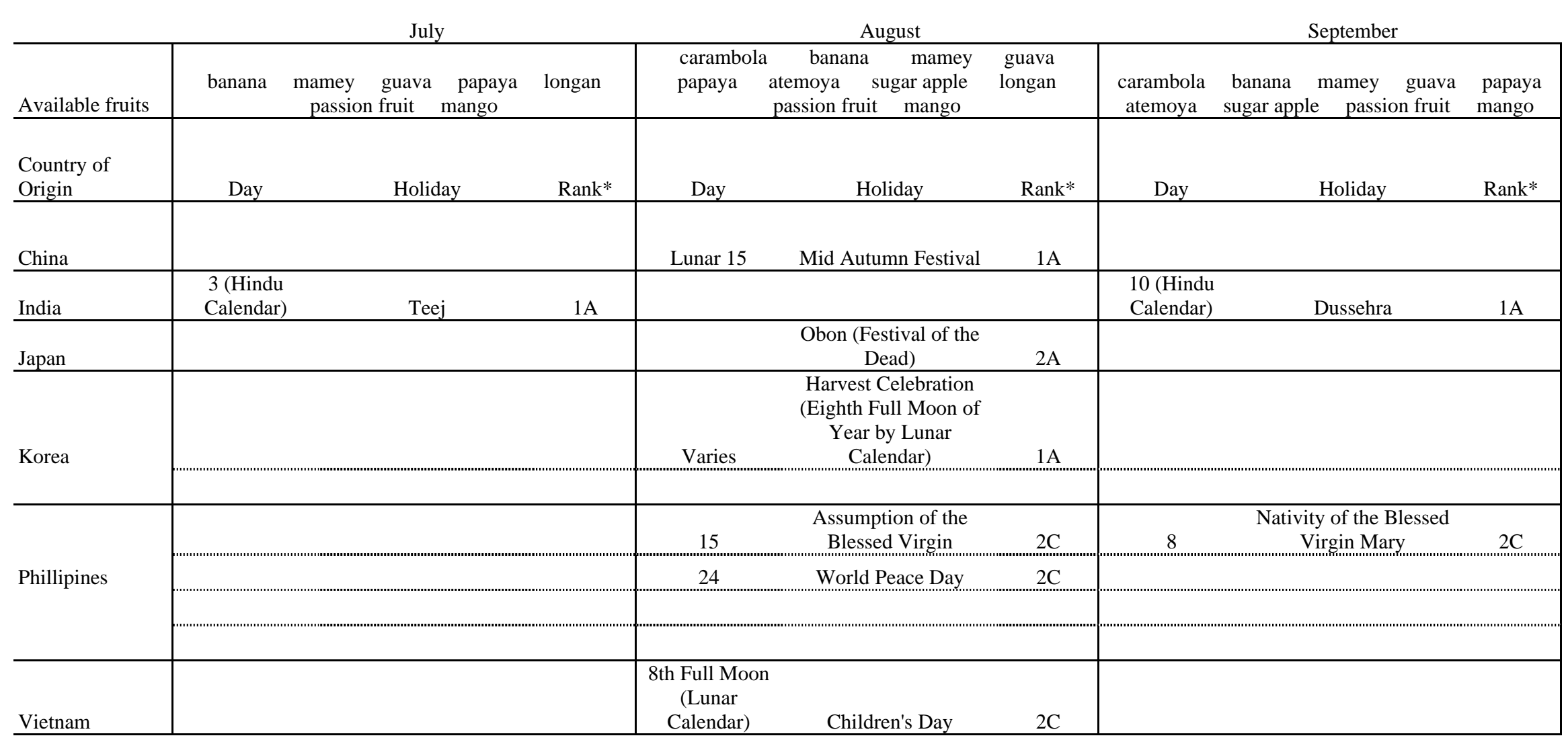

* The numeric portion of the ranking indicates the importance of the holiday: $1=$ very important holiday, $2=$ moderately important holiday and $3=$ minor holiday. Likewise the alphabetic portion of the rank indicates the significance of food in celebrating th 
Appendix Table B-64. Calendar of fruit availability and Asian holidays, continued.

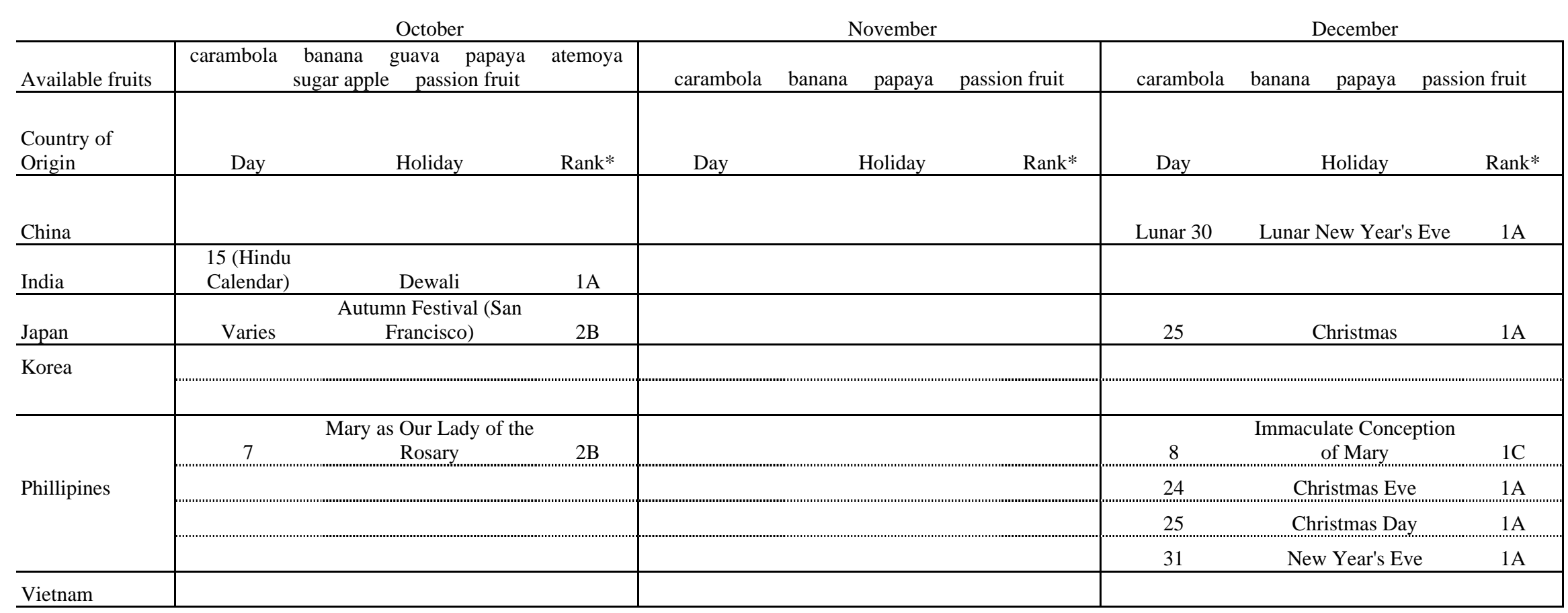

* The numeric portion of the ranking indicates the importance of the holiday: $1=$ very important holiday, $2=$ moderately important holiday and $3=$ minor holiday. Likewise the alphabetic portion of the rank indicates the significance of food in celebrating th 
Appendix Table B-65. Calendar of fruit availability and Hispanic holidays.

\begin{tabular}{|c|c|c|c|c|c|c|c|c|c|}
\hline & \multicolumn{3}{|c|}{ January } & \multicolumn{3}{|c|}{ February } & \multicolumn{3}{|c|}{ March } \\
\hline Available fruits & carambola & $\begin{array}{c}\text { banana mamey gua } \\
\text { passion fruit }\end{array}$ & papaya & carambola & $\begin{array}{c}\text { banana mamey } \mathrm{gu} \\
\text { passion fruit }\end{array}$ & papaya & carambola & $\begin{array}{lll}\text { banana } & \begin{array}{l}\text { mamey } \\
\text { fruit }\end{array} & \text { papaya } \\
\end{array}$ & passion \\
\hline Country of Origin & Day & Holiday & Rank* & Day & Holiday & Rank* & Day & Holiday & Rank* \\
\hline \multirow[b]{2}{*}{ Colombia } & 1 & New Year's Day & $1 \mathrm{~A}$ & & & & Varies & Good Friday & $1 \mathrm{~B}$ \\
\hline & 6 & Epiphany & $3 \mathrm{C}$ & & & & Varies & Easter Sunday & $1 \mathrm{~A}$ \\
\hline \multirow[t]{3}{*}{ Cuba } & 6 & Epiphany & $3 \mathrm{C}$ & Varies & Ash Wednesday & $3 \mathrm{~B}$ & Varies & Palm Sunday & $2 \mathrm{C}$ \\
\hline & & & & Varies & Lent & $3 \mathrm{~B}$ & Varies & Good Friday & $2 \mathrm{~B}$ \\
\hline & & & & 14 & St. Valentine's Day & $2 \mathrm{C}$ & Varies & Easter Sunday & $2 \mathrm{C}$ \\
\hline \multirow{4}{*}{$\begin{array}{l}\text { Dominican } \\
\text { Republic }\end{array}$} & 6 & Three Holy Kings & $1 \mathrm{~B}$ & 14 & St. Valentine's Day & $3 \mathrm{C}$ & Varies & Palm Sunday & $2 \mathrm{C}$ \\
\hline & 21 & Our Lady of Altagracia & $1 \mathrm{C}$ & 27 & Independence Day & $1 \mathrm{C}$ & Varies & Good Friday & $1 \mathrm{~A}$ \\
\hline & Varies & Carnival & $3 \mathrm{C}$ & Varies & Ash Wednesday & $3 \mathrm{C}$ & Varies & Easter Sunday & $1 \mathrm{~B}$ \\
\hline & & & & Varies & Lent & $3 \mathrm{C}$ & & & \\
\hline \multirow[t]{3}{*}{ El Salvador } & 6 & Epiphany & $3 \mathrm{C}$ & 14 & St. Valentine's Day & $2 \mathrm{C}$ & Varies & Palm Sunday & $3 \mathrm{~B}$ \\
\hline & & & & Varies & Ash Wednesday & $2 \mathrm{~B}$ & Varies & Good Friday & $1 \mathrm{~A}$ \\
\hline & & & & Varies & Lent & $2 \mathrm{~B}$ & Varies & Easter Week & $1 \mathrm{~A}$ \\
\hline \multirow[t]{4}{*}{ Mexico } & 6 & Three Holy Kings & $2 \mathrm{~A}$ & 2 & Presentation of Jesus & $2 \mathrm{~B}$ & 21 & Benito Juarez Birthday & $2 \mathrm{C}$ \\
\hline & & & & 5 & Constitution Day & $1 \mathrm{C}$ & Varies & Holy Thursday & $1 \mathrm{~B}$ \\
\hline & & & & 24 & Flag Day & $3 \mathrm{C}$ & Varies & Good Friday & $2 \mathrm{C}$ \\
\hline & & & & & & & Varies & Easter Sunday & $2 \mathrm{C}$ \\
\hline \multirow[t]{2}{*}{ Puerto Rico } & 5 & Epiphany Eve & $2 \mathrm{~A}$ & 14 & St. Valentine's Day & $2 \mathrm{C}$ & Varies & Passover & $1 \mathrm{~A}$ \\
\hline & 6 & Epiphany & $2 \mathrm{~A}$ & Varies & Ash Wednesday & $1 \mathrm{~A}$ & & & \\
\hline
\end{tabular}

* The numeric portion of the ranking indicates the importance of the holiday: $1=$ very important holiday, $2=$ moderately important holiday and $3=$ minor holiday. Likewise the alphabetic portion of the rank indicates the significance of food in celebrating th 
Appendix Table B-65. Calendar of fruit availability and Hispanic holidays, continued.

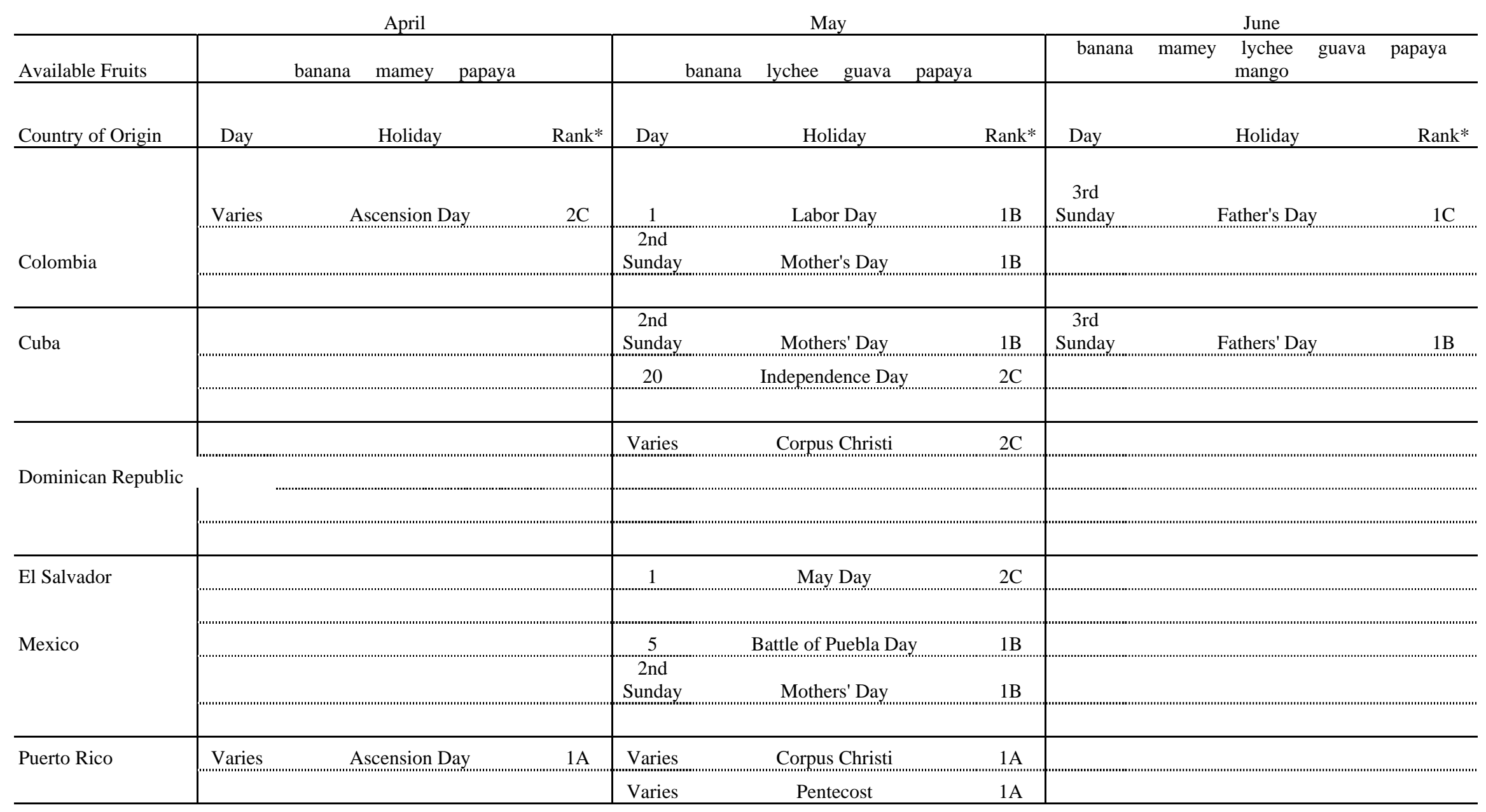

* The numeric portion of the ranking indicates the importance of the holiday: 1=very important holiday, 2=moderately important holiday and $3=$ minor holiday. Likewise the alphabetic portion of the rank indicates the significance of food in celebrating th 
Appendix Table B-65. Calendar of fruit availability and Hispanic holidays, continued.

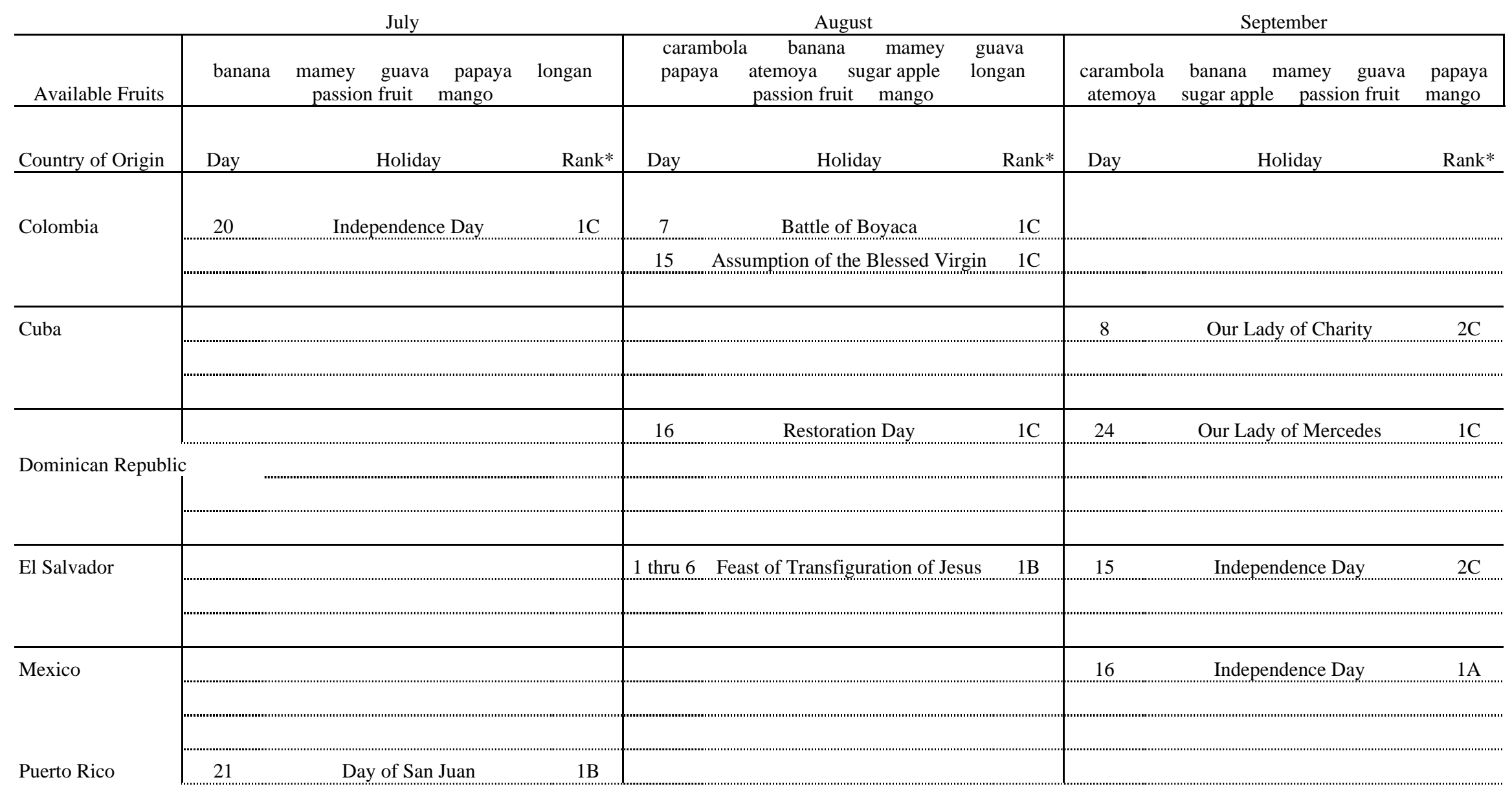

* The numeric portion of the ranking indicates the importance of the holiday: 1=very important holiday, 2=moderately important holiday and $3=$ minor holiday. Likewise the alphabetic portion of the rank indicates the significance of food in celebrating th 
Appendix Table B-65. Calendar of fruit availability and Hispanic holidays, continued.

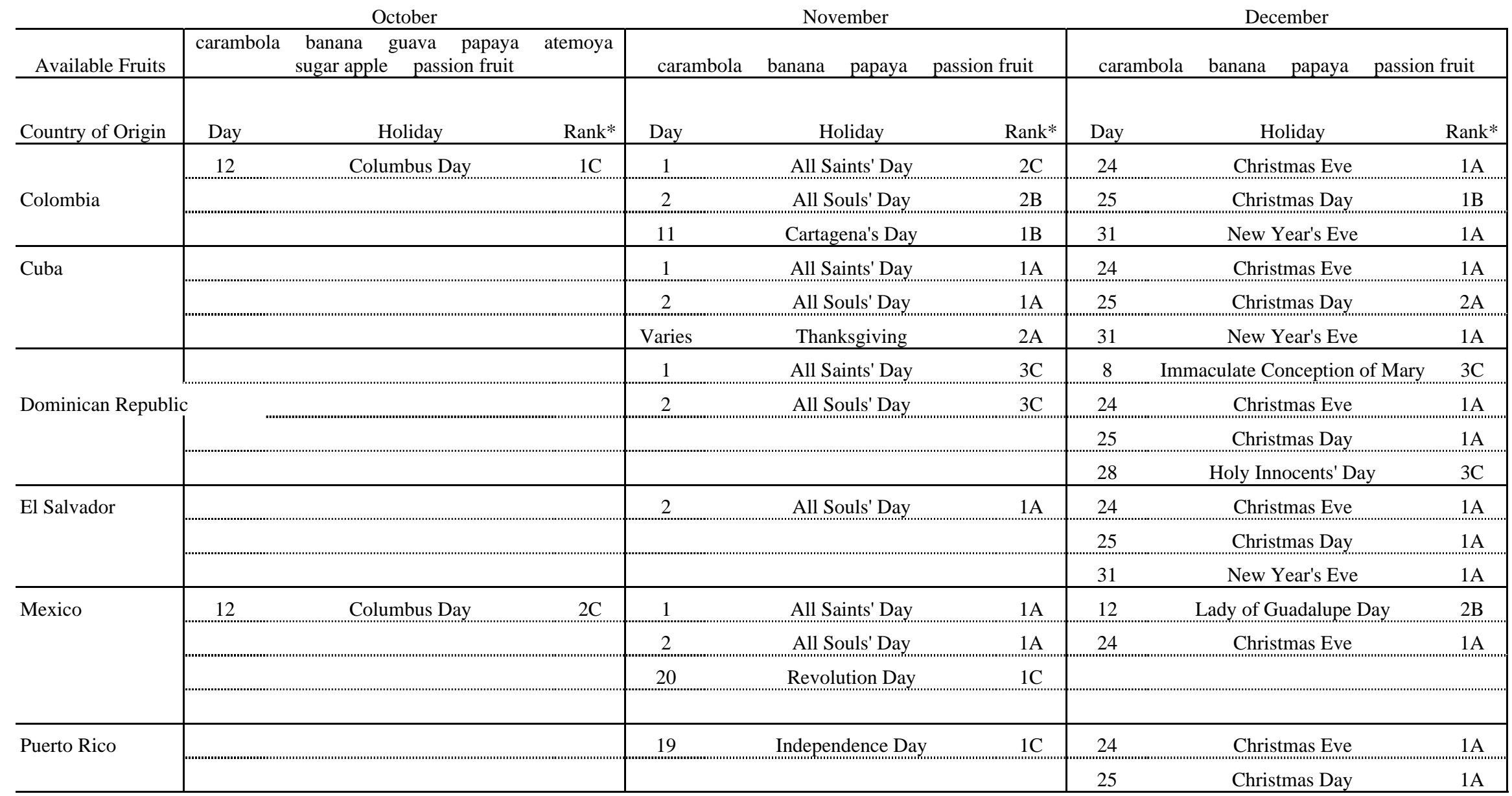

* The numeric portion of the ranking indicates the importance of the holiday: 1=very important holiday, 2=moderately important holiday and $3=$ minor holiday. Likewise the alphabetic portion of the rank indicates the significance of food in celebrating th 
Appendix Table C-1. Chainstore produce executives' comments on atemoya, 75 firms, 30 cities.

\begin{tabular}{|c|c|c|c|c|}
\hline \multirow[t]{2}{*}{ Buyers' Comments } & \multicolumn{2}{|c|}{ Firms } & \multicolumn{2}{|c|}{ Stores } \\
\hline & (Number) & $(\text { Percent })^{a}$ & (Number) & (Percent) $)^{b}$ \\
\hline \multicolumn{5}{|l|}{ Performance/Demand } \\
\hline \multicolumn{5}{|l|}{ Positive: } \\
\hline Fruit is selling ok & 5 & 6.7 & 711 & 4.7 \\
\hline Fruit is selling well & 1 & 1.3 & $--c$ & 1.0 \\
\hline \multicolumn{5}{|l|}{ Negative: } \\
\hline Not carried- unknown to customer & 17 & 22.7 & 4,305 & 28.4 \\
\hline Not carried- no demand & 15 & 20.0 & 2,628 & 17.3 \\
\hline Carry only on special order & 10 & 13.3 & 2,465 & 16.3 \\
\hline Fruit is selling poorly & 12 & 16.0 & 1,660 & 11.0 \\
\hline Not carried- unknown to buyer & 10 & 13.3 & 1,448 & 9.6 \\
\hline Not carried- did at one time; poor seller & 4 & 5.3 & 548 & 3.6 \\
\hline Fruit is rarely requested & 1 & 1.3 & 213 & 1.4 \\
\hline Carry very few of this fruit & 1 & 1.3 & 147 & 1.0 \\
\hline Quantities sold too small to justify carrying & 1 & 1.3 & 125 & 0.8 \\
\hline Sold for variety not profit/low profit & 3 & 4.0 & 672 & 4.4 \\
\hline \multicolumn{5}{|l|}{ Pricing } \\
\hline Lower prices/fruit is too expensive & 10 & 13.3 & 2,403 & 15.9 \\
\hline \multicolumn{5}{|l|}{ Fruit Characteristics/Quality/Pack } \\
\hline Prefer sweet fruit/sweet varieties of fruit & 1 & 1.3 & 1,202 & 7.9 \\
\hline Appearance/quality very important & 2 & 2.7 & 210 & 1.4 \\
\hline \multicolumn{5}{|l|}{ Supply Issues } \\
\hline Supplies of fruit are inconsistent/unreliable & 2 & 2.7 & 515 & 3.4 \\
\hline Season is too short- extend if possible & 2 & 2.7 & 301 & 2.0 \\
\hline \multicolumn{5}{|l|}{ Consumer Markets } \\
\hline$\overline{\text { High income market item }}$ & 5 & 6.7 & 1,603 & 10.6 \\
\hline Anglos are unfamiliar with fruit & 3 & 4.0 & 1,152 & 7.6 \\
\hline Demographically mixed market item & 2 & 2.7 & 775 & 5.1 \\
\hline Hispanic market area- too expensive & 4 & 5.3 & 443 & 2.9 \\
\hline \multicolumn{5}{|l|}{ Advertising and Promotion } \\
\hline$\overline{\text { Consumer education about fruit is needed }}$ & 20 & 26.7 & 3,476 & 22.9 \\
\hline Fruit needs more advertising/promotion & 14 & 18.7 & 2,461 & 16.2 \\
\hline Retailer education about fruit is needed & 4 & 5.3 & 736 & 4.9 \\
\hline Needs in-store demonstrations & 5 & 6.7 & 460 & 3.0 \\
\hline
\end{tabular}


Appendix Table C-2. Chainstore produce executives' comments on specialty bananas, 75 firms, 30 cities.

\begin{tabular}{|c|c|c|c|c|}
\hline \multirow[t]{2}{*}{ Buyers' Comments } & \multicolumn{2}{|c|}{ Firms } & \multicolumn{2}{|c|}{ Stores } \\
\hline & (Number) & (Percent) $^{a}$ & (Number) & (Percent) $^{b}$ \\
\hline \multicolumn{5}{|l|}{ Performance/Demand } \\
\hline \multicolumn{5}{|l|}{$\begin{array}{l}\text { Positive: } \\
\end{array}$} \\
\hline Fruit is selling ok & 10 & 13.3 & 1,484 & 9.8 \\
\hline Fruit is selling well & 3 & 4.0 & 985 & 6.5 \\
\hline Sales are improving & 2 & 2.7 & 412 & 2.7 \\
\hline Fruit has much potential & 1 & 1.3 & 241 & 1.6 \\
\hline \multicolumn{5}{|l|}{ Negative: } \\
\hline Fruit is selling poorly & 25 & 33.3 & 5,152 & 34.0 \\
\hline Low demand for fruit & 10 & 13.3 & 2,804 & 18.5 \\
\hline Carry only on special order & 8 & 10.7 & 2,243 & 14.8 \\
\hline Not carried- no demand & 14 & 18.7 & 2,014 & 13.3 \\
\hline Not carried- did at one time; poor seller & 6 & 8.0 & 776 & 5.1 \\
\hline Fruit is rarely requested & 1 & 1.3 & 400 & 2.6 \\
\hline Not carried- unknown to customer & 3 & 4.0 & 278 & 1.8 \\
\hline Carry very few of this fruit & 2 & 2.7 & 125 & 0.8 \\
\hline \multicolumn{5}{|l|}{ Pricing } \\
\hline Lower prices/fruit is too expensive & 8 & 10.7 & 2,246 & 14.8 \\
\hline \multicolumn{5}{|l|}{ Fruit Characteristics/Quality/Pack } \\
\hline Often mishandled- arrives damaged & 8 & 10.7 & 1,387 & 9.2 \\
\hline Appearance/quality very important & 4 & 5.3 & 807 & 5.3 \\
\hline Fruit is unattractive & 2 & 2.7 & 593 & 3.9 \\
\hline Can't be stored or displayed cold & 3 & 4.0 & 414 & 2.7 \\
\hline Fruit must be ripe to sell & 1 & 1.3 & 251 & 1.7 \\
\hline Improve flavor & 1 & 1.3 & 147 & 1.0 \\
\hline "Lunch-box" (small) size fruit is preferred & 1 & 1.3 & 147 & 1.0 \\
\hline Quality is currently poor & 1 & 1.3 & 147 & 1.0 \\
\hline \multicolumn{5}{|l|}{ Supply Issues } \\
\hline Season is too short- extend if possible & 1 & 1.3 & 187 & 1.2 \\
\hline Supplies of fruit are inconsistent/unreliable & 1 & 1.3 & 101 & 0.7 \\
\hline \multicolumn{5}{|l|}{ Consumer Markets } \\
\hline Hispanic market area- too expensive & 13 & 17.3 & 3,211 & 21.2 \\
\hline Ethnic market item & 6 & 8.0 & 1,894 & 12.5 \\
\hline Anglos are unfamiliar with fruit & 5 & 6.7 & 1,699 & 11.2 \\
\hline Demographically mixed market item & 1 & 1.3 & 650 & 4.3 \\
\hline Asian market item & 1 & 1.3 & 125 & 0.8 \\
\hline High income market item & 1 & 1.3 & 90 & 0.6 \\
\hline \multicolumn{5}{|l|}{ Advertising and Promotion } \\
\hline Consumer education about fruit is needed & 22 & 29.3 & 5,018 & 33.1 \\
\hline Fruit needs more advertising/promotion & 16 & 21.3 & 3,599 & 23.7 \\
\hline Retailer education about fruit is needed & 4 & 5.3 & 736 & 4.9 \\
\hline Fruit needs in-store demonstrations & 7 & 9.3 & 693 & 4.6 \\
\hline More P.O.P. material is needed & 1 & 1.3 & 350 & 2.3 \\
\hline Specialty bananas have received a lot of promotion & 1 & 1.3 & 180 & 1.2 \\
\hline
\end{tabular}


Appendix Table C-3. Chainstore produce executives' comments on carambola, 75 firms, 30 cities.

\begin{tabular}{|c|c|c|c|c|}
\hline \multirow[t]{2}{*}{ Buyers' Comments } & \multicolumn{2}{|c|}{ Firms } & \multicolumn{2}{|c|}{ Stores } \\
\hline & (Number) & (Percent) $^{a}$ & (Number) & (Percent) $^{b}$ \\
\hline \multicolumn{5}{|l|}{ Performance/Demand } \\
\hline \multicolumn{5}{|l|}{ Positive: } \\
\hline Fruit is selling well & 32 & 42.7 & 5,355 & 35.3 \\
\hline Fruit is selling ok & 18 & 24.0 & 3,857 & 25.5 \\
\hline Sales are improving & 15 & 20.0 & 3,478 & 22.9 \\
\hline Fruit has much potential & 3 & 4.0 & 635 & 4.2 \\
\hline High demand for fruit & 2 & 2.7 & 268 & 1.8 \\
\hline \multicolumn{5}{|l|}{ Negative: } \\
\hline Fruit is selling poorly & 10 & 13.3 & 1,850 & 12.2 \\
\hline Not carried- no demand & 2 & 2.7 & 267 & 1.8 \\
\hline Carry very few of this fruit & 1 & 1.3 & 147 & 1.0 \\
\hline Not carried- did at one time; poor seller & 1 & 1.3 & 120 & 0.8 \\
\hline Carry only on special order & 1 & 1.3 & 45 & 0.3 \\
\hline Low demand for fruit & 1 & 1.3 & 45 & 0.3 \\
\hline \multicolumn{5}{|l|}{ Pricing } \\
\hline Lower prices/fruit is too expensive & 14 & 18.7 & 3,219 & 21.2 \\
\hline Fruit sells well if on sale & 4 & 5.3 & 573 & 3.8 \\
\hline Sells well if price is less than $\$ 1$ per fruit & 4 & 5.3 & 543 & 3.6 \\
\hline Sells well if price is 2 or 3 fruit per $\$ 1$ & 3 & 4.0 & 527 & 3.5 \\
\hline \multicolumn{5}{|l|}{ Fruit Characteristics/Quality/Pack } \\
\hline Prefer sweet fruit/sweet varieties of fruit & 2 & 2.7 & 1,382 & 9.1 \\
\hline Improve packing & 1 & 1.3 & 1,202 & 7.9 \\
\hline Improve flavor & 3 & 4.0 & 517 & 3.4 \\
\hline Prefer large fruit & 3 & 4.0 & 459 & 3.0 \\
\hline Appearance/quality very important & 2 & 2.7 & 210 & 1.4 \\
\hline Prefer small fruit & 1 & 1.3 & 124 & 0.8 \\
\hline "Lunch-box" (small) size fruit is preferred & 1 & 1.3 & 69 & 0.5 \\
\hline \multicolumn{5}{|l|}{ Supply Issues } \\
\hline Season is too short-extend if possible & 14 & 18.7 & 2,424 & 16.0 \\
\hline Increase production of fruit & 3 & 4.0 & 493 & 3.3 \\
\hline Supplies of fruit are inconsistent/unreliable & 4 & 5.3 & 439 & 2.9 \\
\hline \multicolumn{5}{|l|}{ Consumer Markets } \\
\hline$\overline{\text { High income market item }}$ & 5 & 6.7 & 1,843 & 12.2 \\
\hline Anglos are unfamiliar with fruit & 3 & 4.0 & 1,152 & 7.6 \\
\hline Demographically mixed market item & 3 & 4.0 & 824 & 5.4 \\
\hline Asian market item & 1 & 1.3 & 187 & 1.2 \\
\hline Hispanic market area- too expensive & 1 & 1.3 & 120 & 0.8 \\
\hline Ethnic market item & 1 & 1.3 & 80 & 0.5 \\
\hline \multicolumn{5}{|l|}{ Advertising and Promotion } \\
\hline Consumer education about fruit is needed & 25 & 33.3 & 6,970 & 46.0 \\
\hline Fruit needs more advertising/promotion & 16 & 21.3 & 2,968 & 19.6 \\
\hline Retailer education about fruit is needed & 4 & 5.3 & 736 & 4.9 \\
\hline Needs in-store demonstrations & 6 & 8.0 & 550 & 3.6 \\
\hline More P.O.P. material is needed & 3 & 4.0 & 328 & 2.2 \\
\hline Carambola has received a lot of promotion & 3 & 4.0 & 323 & 2.1 \\
\hline
\end{tabular}


Appendix Table C-4. Chainstore produce executives' comments on guava, 75 firms, 30 cities.

\begin{tabular}{|c|c|c|c|c|}
\hline \multirow[t]{2}{*}{ Buyers' Comments } & \multicolumn{2}{|c|}{ Firms } & \multicolumn{2}{|c|}{ Stores } \\
\hline & (Number) & (Percent) $^{a}$ & (Number) & (Percent) $^{b}$ \\
\hline \multicolumn{5}{|l|}{ Performance/Demand } \\
\hline \multicolumn{5}{|l|}{ Positive: } \\
\hline Fruit is selling ok & 6 & 8.0 & 1,259 & 8.3 \\
\hline Sales are improving & 2 & 2.7 & 387 & 2.6 \\
\hline Fruit is selling well & 2 & 2.7 & 332 & 2.2 \\
\hline \multicolumn{5}{|l|}{ Negative: } \\
\hline Fruit is selling poorly & 36 & 48.0 & 6,742 & 44.5 \\
\hline Low demand for fruit & 18 & 24.0 & 3,526 & 23.3 \\
\hline Carry only on special order & 10 & 13.3 & 2,716 & 17.9 \\
\hline Not carried- no demand & 10 & 13.3 & 1,530 & 10.1 \\
\hline Not carried- did at one time; poor seller & 4 & 5.3 & 421 & 2.8 \\
\hline Fruit is rarely requested & 1 & 1.3 & 400 & 2.6 \\
\hline Not carried- unknown to customer & 1 & 1.3 & 260 & 1.7 \\
\hline Not carried- unknown to buyer & 1 & 1.3 & 150 & 1.0 \\
\hline Carry very few of this fruit & 1 & 1.3 & 147 & 1.0 \\
\hline \multicolumn{5}{|l|}{ Pricing } \\
\hline Lower prices/fruit is too expensive & 10 & 13.3 & 2,030 & 13.4 \\
\hline \multicolumn{5}{|l|}{ Fruit Characteristics/Quality/Pack } \\
\hline Appearance/quality very important & 2 & 2.7 & 210 & 1.4 \\
\hline Use more consistent sizing grades & 1 & 1.3 & 200 & 1.3 \\
\hline Fruit must be ripe to sell & 1 & 1.3 & 132 & 0.9 \\
\hline \multicolumn{5}{|l|}{ Supply Issues } \\
\hline Supplies of fruit are inconsistent/unreliable & 4 & 5.3 & 423 & 2.8 \\
\hline Season is too short- extend if possible & 1 & 1.3 & 187 & 1.2 \\
\hline \multicolumn{5}{|l|}{ Consumer Markets } \\
\hline 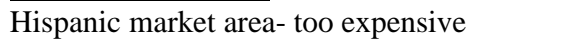 & 10 & 13.3 & 1,960 & 12.9 \\
\hline Anglos are unfamiliar with fruit & 4 & 5.3 & 1,552 & 10.2 \\
\hline Ethnic market item & 3 & 4.0 & 958 & 6.3 \\
\hline High income market item & 5 & 6.7 & 882 & 5.8 \\
\hline Demographically mixed market item & 1 & 1.3 & 81 & 0.5 \\
\hline \multicolumn{5}{|l|}{ Advertising and Promotion } \\
\hline$\overline{\text { Consumer education about fruit is needed }}$ & 30 & 40.0 & 7,316 & 48.3 \\
\hline Fruit needs more advertising/promotion & 21 & 28.0 & 3,570 & 23.6 \\
\hline Retailer education about fruit is needed & 4 & 5.3 & 736 & 4.9 \\
\hline Needs in-store demonstrations & 7 & 9.3 & 683 & 4.5 \\
\hline Guava has received a lot of promotion & 2 & 2.7 & 550 & 3.6 \\
\hline More P.O.P. material is needed & 1 & 1.3 & 200 & 1.3 \\
\hline
\end{tabular}


Appendix Table C-5. Chainstore produce executives' comments on lychee, 75 firms, 30 cities.

\begin{tabular}{|c|c|c|c|c|}
\hline \multirow[t]{2}{*}{ Buyers' Comments } & \multicolumn{2}{|c|}{ Firms } & \multicolumn{2}{|c|}{ Stores } \\
\hline & (Number) & ${ }_{\text {(Percent) }}{ }^{a}$ & (Number) & ${ }_{\text {(Percent) }}^{b}$ \\
\hline \multicolumn{5}{|l|}{ Performance/Demand } \\
\hline \multicolumn{5}{|l|}{ Positive: } \\
\hline Fruit is selling ok & 5 & 6.7 & 1,153 & 7.6 \\
\hline Fruit is selling well & 6 & 8.0 & 1,152 & 7.6 \\
\hline Sales are improving & 1 & 1.3 & 62 & 0.4 \\
\hline \multicolumn{5}{|l|}{ Negative: } \\
\hline Fruit is selling poorly & 19 & 25.3 & 3,316 & 21.9 \\
\hline Carry only on special order & 20 & 26.7 & 3,186 & 21.0 \\
\hline Not carried- no demand & 16 & 21.3 & 2,541 & 16.8 \\
\hline Low demand for fruit & 13 & 17.3 & 2,536 & 16.7 \\
\hline Not carried- unknown to customer & 2 & 2.7 & 862 & 5.7 \\
\hline Not carried- unknown to buyer & 4 & 5.3 & 795 & 5.2 \\
\hline Carry very few of this fruit & 2 & 2.7 & 279 & 1.8 \\
\hline Fruit is rarely requested & 2 & 2.7 & 277 & 1.8 \\
\hline Not carried- did at one time; poor seller & 1 & 1.3 & 120 & 0.8 \\
\hline \multicolumn{5}{|l|}{ Pricing } \\
\hline Lower prices/fruit is too expensive & 12 & 16.0 & 2,773 & 18.3 \\
\hline Sells well if on sale & 1 & 1.3 & 198 & 1.3 \\
\hline \multicolumn{5}{|l|}{ Fruit Characteristics/Quality/Pack } \\
\hline Very fragile/hard to get high quality fruit & 2 & 2.7 & 290 & 1.9 \\
\hline Appearance/quality very important & 2 & 2.7 & 210 & 1.4 \\
\hline Prefer Hispanic to Asian lychee & 1 & 1.3 & 200 & 1.3 \\
\hline Improve packing & 1 & 1.3 & 101 & 0.7 \\
\hline Often mishandled- arrives damaged & 1 & 1.3 & 94 & 0.6 \\
\hline \multicolumn{5}{|l|}{ Supply Issues } \\
\hline$\overline{\text { Supplies of fruit are inconsistent/unreliable }}$ & 3 & 4.0 & 1,065 & 7.0 \\
\hline Season is too short- extend if possible & 5 & 6.7 & 1,013 & 6.7 \\
\hline Customers will buy large quantities if available & 4 & 5.3 & 579 & 3.8 \\
\hline Increase production of fruit & 1 & 1.3 & 149 & 1.0 \\
\hline \multicolumn{5}{|l|}{ Consumer Markets } \\
\hline Asian market item & 14 & 18.7 & 3,107 & 20.5 \\
\hline Hispanic market area- too expensive & 4 & 5.3 & 1,616 & 10.7 \\
\hline Anglos are unfamiliar with fruit & 3 & 4.0 & 1,152 & 7.6 \\
\hline Few Asians in area & 3 & 4.0 & 880 & 5.8 \\
\hline Demographically mixed market item & 2 & 2.7 & 775 & 5.1 \\
\hline Ethnic market item & 2 & 2.7 & 519 & 3.4 \\
\hline High income market item & 2 & 2.7 & 315 & 2.1 \\
\hline \multicolumn{5}{|l|}{ Advertising and Promotion } \\
\hline Consumer education about fruit is needed & 25 & 33.3 & 4,924 & 32.5 \\
\hline Fruit needs more advertising/promotion & 11 & 14.7 & 2,225 & 14.7 \\
\hline Retailer education about fruit is needed & 5 & 6.7 & 886 & 5.8 \\
\hline Fruit needs in-store demonstrations & 5 & 6.7 & 460 & 3.0 \\
\hline
\end{tabular}

\footnotetext{
${ }^{a}$ Percentages are based upon a total of 75 firms.

${ }^{b}$ Percentages are based upon a total of 15,155 stores.

${ }^{c}$ Data not reported to avoid disclosure.
} 
Appendix Table C-6. Chainstore produce executives' comments on longan, 75 firms, 30 cities.

\begin{tabular}{|c|c|c|c|c|}
\hline \multirow[t]{2}{*}{ Buyers' Comments } & \multicolumn{2}{|c|}{ Firms } & \multicolumn{2}{|c|}{ Stores } \\
\hline & (Number) & (Percent) $^{a}$ & (Number) & (Percent) $^{b}$ \\
\hline \multicolumn{5}{|l|}{$\underline{\text { Performance/Demand }}$} \\
\hline \multicolumn{5}{|l|}{ Positive: } \\
\hline Fruit is selling well & 1 & 1.3 & 241 & 1.6 \\
\hline \multicolumn{5}{|l|}{ Negative: } \\
\hline Not carried- no demand & 21 & 28.0 & 4,511 & 29.8 \\
\hline Not carried- unknown to buyer & 20 & 26.7 & 3,744 & 24.7 \\
\hline Carry only on special order & 8 & 10.7 & 1,997 & 13.2 \\
\hline Fruit is selling poorly & 9 & 12.0 & 1,712 & 11.3 \\
\hline Not carried- unknown to customer & 8 & 10.7 & 1,519 & 10.0 \\
\hline Low demand for fruit & 5 & 6.7 & 830 & 5.5 \\
\hline Not carried- did at one time; poor seller & 3 & 4.0 & 380 & 2.5 \\
\hline Fruit is rarely requested & 2 & 2.7 & 326 & 2.2 \\
\hline Carry very few of this fruit & 1 & 1.3 & 147 & 1.0 \\
\hline \multicolumn{5}{|l|}{ Pricing } \\
\hline Lower prices/fruit is too expensive & 5 & 6.7 & 1,223 & 8.1 \\
\hline \multicolumn{5}{|l|}{ Fruit Characteristics/Quality/Pack } \\
\hline Appearance/quality very important & 2 & 2.7 & 210 & 1.4 \\
\hline Very fragile/hard to get high quality fruit & 1 & 1.3 & 187 & 1.2 \\
\hline Improve packing & 1 & 1.3 & 101 & 0.7 \\
\hline \multicolumn{5}{|l|}{ Supply Issues } \\
\hline Season is too short- extend if possible & 3 & 4.0 & 658 & 4.3 \\
\hline Customers will buy large quantities if available & 2 & 2.7 & 307 & 2.0 \\
\hline \multicolumn{5}{|l|}{ Consumer Markets } \\
\hline Asian market item & 5 & 6.7 & 1,365 & 9.0 \\
\hline Anglos are unfamiliar with fruit & 3 & 4.0 & 1,152 & 7.6 \\
\hline Ethnic market item & 1 & 1.3 & 225 & 1.5 \\
\hline Demographically mixed market item & 1 & 1.3 & 125 & 0.8 \\
\hline Hispanic market area- too expensive & 1 & 1.3 & 120 & 0.8 \\
\hline High income market item & 1 & 1.3 & 90 & 0.6 \\
\hline \multicolumn{5}{|l|}{ Advertising and Promotion } \\
\hline Consumer education about fruit is needed & 16 & 21.3 & 3,121 & 20.6 \\
\hline Fruit needs more advertising/promotion & 11 & 14.7 & 2,225 & 14.7 \\
\hline Retailer education about fruit is needed & 4 & 5.3 & 736 & 4.9 \\
\hline Fruit needs in-store demonstrations & 5 & 6.7 & 460 & 3.0 \\
\hline Longan has received a lot of promotion & 1 & 1.3 & 241 & 1.6 \\
\hline
\end{tabular}


Appendix Table C-7. Chainstore produce executives' comments on mamey sapote, 75 firms, 30 cities.

\begin{tabular}{|c|c|c|c|c|}
\hline \multirow[t]{2}{*}{ Buyers' Comments } & \multicolumn{2}{|c|}{ Firms } & \multicolumn{2}{|c|}{ Stores } \\
\hline & (Number) & (Percent) $^{a}$ & (Number) & ${ }_{\text {(Percent) }}^{b}$ \\
\hline \multicolumn{5}{|l|}{ Performance/Demand } \\
\hline \multicolumn{5}{|l|}{ Positive: } \\
\hline Fruit is selling well & 2 & 2.7 & 753 & 5.0 \\
\hline Sales are improving & 1 & 1.3 & 200 & 1.3 \\
\hline Fruit is selling ok & 1 & 1.3 & 90 & 0.6 \\
\hline Fruit has much potential & 1 & 1.3 & 64 & 0.4 \\
\hline \multicolumn{5}{|l|}{ Negative: } \\
\hline Not carried- no demand & 20 & 26.7 & 3,980 & 26.3 \\
\hline Not carried- unknown to buyer & 15 & 20.0 & 2,231 & 14.7 \\
\hline Carry only on special order & 10 & 13.3 & 1,810 & 11.9 \\
\hline Fruit is selling poorly & 13 & 17.3 & 1,698 & 11.2 \\
\hline Not carried- unknown to customer & 6 & 8.0 & 1,502 & 9.9 \\
\hline Low demand for fruit & 6 & 8.0 & 1,317 & 8.7 \\
\hline Not carried- did at one time; poor seller & 3 & 4.0 & 424 & 2.8 \\
\hline Carry very few of this fruit & 1 & 1.3 & 147 & 1.0 \\
\hline \multicolumn{5}{|l|}{ Pricing } \\
\hline Lower prices/fruit is too expensive & 6 & 8.0 & 1,873 & 12.4 \\
\hline \multicolumn{5}{|l|}{ Fruit Characteristics/Quality/Pack } \\
\hline Appearance/quality very important & 2 & 2.7 & 210 & 1.4 \\
\hline Prefer large fruit & 1 & 1.3 & 200 & 1.3 \\
\hline Very fragile/hard to get high quality fruit & 1 & 1.3 & 149 & 1.0 \\
\hline Quality is currently poor & 1 & 1.3 & 149 & 1.0 \\
\hline Improve packing & 1 & 1.3 & 149 & 1.0 \\
\hline \multicolumn{5}{|l|}{ Supply Issues } \\
\hline$\overline{\text { Increase production of fruit }}$ & 1 & 1.3 & 390 & 2.6 \\
\hline Supplies of fruit are inconsistent/unreliable & 4 & 5.3 & 361 & 2.4 \\
\hline Season is too short- extend if possible & 2 & 2.7 & 301 & 2.0 \\
\hline \multicolumn{5}{|l|}{ Consumer Markets } \\
\hline Hispanic market area- too expensive & 6 & 8.0 & 2,295 & 15.1 \\
\hline Anglos are unfamiliar with fruit & 3 & 4.0 & 1,152 & 7.6 \\
\hline Ethnic market item & 3 & 4.0 & 958 & 6.3 \\
\hline Demographically mixed market item & 2 & 2.7 & 775 & 5.1 \\
\hline High income market item & 2 & 2.7 & 170 & 1.1 \\
\hline \multicolumn{5}{|l|}{$\underline{\text { Advertising and Promotion }}$} \\
\hline$\overline{\text { Consumer education about fruit is needed }}$ & 17 & 22.7 & 3,315 & 21.9 \\
\hline Fruit needs more advertising/promotion & 12 & 16.0 & 2,319 & 15.3 \\
\hline Retailer education about fruit is needed & 4 & 5.3 & 736 & 4.9 \\
\hline Fruit needs in-store demonstrations & 5 & 6.7 & 460 & 3.0 \\
\hline
\end{tabular}

${ }^{a}$ Percentages are based upon a total of 75 firms.

$b$ Percentages are based upon a total of 15,155 stores.

c Data not reported to avoid disclosure. 
Appendix Table C-8. Chainstore produce executives' comments on mango, 75 firms, 30 cities.

\begin{tabular}{|c|c|c|c|c|}
\hline \multirow[t]{2}{*}{ Buyers' Comments } & \multicolumn{2}{|c|}{ Firms } & \multicolumn{2}{|c|}{ Stores } \\
\hline & (Number) & (Percent) $^{a}$ & (Number) & (Percent) $^{b}$ \\
\hline \multicolumn{5}{|l|}{ Performance/Demand } \\
\hline \multicolumn{5}{|l|}{ Positive: } \\
\hline Fruit is selling well & 54 & 72.0 & 9,808 & 64.7 \\
\hline Sales are improving & 16 & 21.3 & 4,711 & 31.1 \\
\hline Fruit is selling ok & 3 & 4.0 & 510 & 3.4 \\
\hline High demand for fruit & 3 & 4.0 & 323 & 2.1 \\
\hline Sells more than any trop fruit & 2 & 2.7 & 180 & 1.2 \\
\hline Fruit has much potential & 1 & 1.3 & 125 & 0.8 \\
\hline \multicolumn{5}{|l|}{ Negative: } \\
\hline Fruit is selling poorly & 3 & 4.0 & 917 & 6.1 \\
\hline Low demand for fruit & 1 & 1.3 & 120 & 0.8 \\
\hline \multicolumn{5}{|l|}{ Pricing } \\
\hline Sells well if on sale & 5 & 6.7 & 1,808 & 11.9 \\
\hline Lower prices/fruit is too expensive & 8 & 10.7 & 1,507 & 9.9 \\
\hline Sells well if price is 2 or 3 fruit per $\$ 1$ & 3 & 4.0 & 560 & 3.7 \\
\hline Sells well if price is less than $\$ 1$ per fruit & 3 & 4.0 & 402 & 2.7 \\
\hline \multicolumn{5}{|l|}{ Fruit Characteristics/Quality/Pack } \\
\hline Fruit must have good blush & 16 & 21.3 & 4,401 & 29.0 \\
\hline Tommy Atkins is a preferred variety & 19 & 25.3 & 3,192 & 21.1 \\
\hline Appearance/quality very important & 11 & 14.7 & 2,026 & 13.4 \\
\hline Green fruit is undesirable & 4 & 5.3 & 1,794 & 11.8 \\
\hline Quality is currently good & 1 & 1.3 & 450 & 3.0 \\
\hline Fruit must be ripe to sell & 3 & 4.0 & 399 & 2.6 \\
\hline Prefer large fruit & 2 & 2.7 & 388 & 2.6 \\
\hline Kent is a preferred variety & 1 & 1.3 & 370 & 2.4 \\
\hline Improve packing & 2 & 2.7 & 305 & 2.0 \\
\hline Prefer small fruit & 2 & 2.7 & 184 & 1.2 \\
\hline Improve quality standards & 1 & 1.3 & 180 & 1.2 \\
\hline \multicolumn{5}{|l|}{ Supply Issues } \\
\hline Season is too short- extend if possible & 3 & 4.0 & 336 & 2.2 \\
\hline Increase production of fruit & 2 & 2.7 & 223 & 1.5 \\
\hline \multicolumn{5}{|l|}{ Consumer Markets } \\
\hline Hispanic market area- too expensive & 26 & 34.7 & 5,953 & 39.3 \\
\hline Demographically mixed market item & 13 & 17.3 & 4,063 & 26.8 \\
\hline Anglos are unfamiliar with fruit & 3 & 4.0 & 1,152 & 7.6 \\
\hline Ethnic market item & 6 & 8.0 & 1,133 & 7.5 \\
\hline Haitian market area- too expensive & 2 & 2.7 & 770 & 5.1 \\
\hline High income market item & 4 & 5.3 & 549 & 3.6 \\
\hline Asian or Islander market item & 3 & 4.0 & 505 & 3.3 \\
\hline \multicolumn{5}{|l|}{ Advertising and Promotion } \\
\hline Fruit needs more advertising/promotion & 14 & 18.7 & 3,167 & 20.9 \\
\hline Consumer education about fruit is needed & 17 & 22.7 & 3,010 & 19.9 \\
\hline Retailer education about fruit is needed & 4 & 5.3 & 736 & 4.9 \\
\hline Mango has received a lot of promotion & 4 & 5.3 & 721 & 4.8 \\
\hline Fruit needs in-store demonstrations & 5 & 6.7 & 460 & 3.0 \\
\hline More P.O.P. material is needed & 2 & 2.7 & 217 & 1.4 \\
\hline
\end{tabular}


Appendix Table C-9. Chainstore produce executives' comments on papaya, 75 firms, 30 cities.

\begin{tabular}{|c|c|c|c|c|}
\hline \multirow[t]{2}{*}{ Buyers' Comments } & \multicolumn{2}{|c|}{ Firms } & \multicolumn{2}{|c|}{ Stores } \\
\hline & (Number) & ${ }_{\text {(Percent) }}{ }^{a}$ & (Number) & ${ }_{\text {(Percent) }}^{b}$ \\
\hline \multicolumn{5}{|l|}{ Performance/Demand } \\
\hline \multicolumn{5}{|l|}{ Positive: } \\
\hline Fruit is selling ok & 30 & 40.0 & 5,672 & 37.4 \\
\hline Fruit is selling well & 19 & 25.3 & 3,158 & 20.8 \\
\hline Sales are improving & 5 & 6.7 & 1,338 & 8.8 \\
\hline Fruit has much potential & 3 & 4.0 & 589 & 3.9 \\
\hline \multicolumn{5}{|l|}{ Negative: } \\
\hline Fruit is selling poorly & 8 & 10.7 & 1,623 & 10.7 \\
\hline Low demand for fruit & 3 & 4.0 & 410 & 2.7 \\
\hline Carry very few of this fruit & 1 & 1.3 & 141 & 0.9 \\
\hline \multicolumn{5}{|l|}{ Pricing } \\
\hline Lower prices/fruit is too expensive & 16 & 21.3 & 3,230 & 21.3 \\
\hline Sells well if on sale & 1 & 1.3 & 481 & 3.2 \\
\hline Sells well if price is less than $\$ 1$ per fruit & 5 & 6.7 & 287 & 1.9 \\
\hline \multicolumn{5}{|l|}{ Fruit Characteristics/Quality/Pack } \\
\hline People are unsure when fruit is ripe & 2 & 2.7 & 557 & 3.7 \\
\hline Prefer small fruit & 2 & 2.7 & 524 & 3.5 \\
\hline Improve quality standards & 1 & 1.3 & 390 & 2.6 \\
\hline Fruit must be ripe to sell & 3 & 4.0 & 384 & 2.5 \\
\hline Prefer sweet fruit/sweet varieties of fruit & 2 & 2.7 & 361 & 2.4 \\
\hline Appearance/quality very important & 4 & 5.3 & 353 & 2.3 \\
\hline Prefer large fruit & 3 & 4.0 & 334 & 2.2 \\
\hline Packing has improved & 2 & 2.7 & 312 & 2.1 \\
\hline Green fruit is undesirable & 1 & 1.3 & 225 & 1.5 \\
\hline People buy fruit for health benefits/nutrition & 3 & 4.0 & 220 & 1.5 \\
\hline Can't be stored or displayed cold & 1 & 1.3 & 200 & 1.3 \\
\hline Quality is currently good & 1 & 1.3 & 180 & 1.2 \\
\hline Prefer yellow-fleshed varieties & 2 & 2.7 & 143 & 0.9 \\
\hline \multicolumn{5}{|l|}{ Supply Issues } \\
\hline Supplies of fruit are inconsistent/unreliable & 2 & 2.7 & 564 & 3.7 \\
\hline Season is too short- extend if possible & 1 & 1.3 & 187 & 1.2 \\
\hline \multicolumn{5}{|l|}{ Consumer Markets } \\
\hline 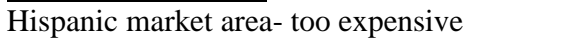 & 12 & 16.0 & 2,276 & 15.0 \\
\hline Demographically mixed market item & 6 & 8.0 & 1,830 & 12.1 \\
\hline Anglos are unfamiliar with fruit & 3 & 4.0 & 1,152 & 7.6 \\
\hline Haitian market area- too expensive & 2 & 2.7 & 850 & 5.6 \\
\hline Ethnic market item & 4 & 5.3 & 775 & 5.1 \\
\hline High income market item & 5 & 6.7 & 548 & 3.6 \\
\hline Asian market item & 2 & 2.7 & 210 & 1.4 \\
\hline \multicolumn{5}{|l|}{ Advertising and Promotion } \\
\hline Consumer education about fruit is needed & 24 & 32.0 & 4,947 & 32.6 \\
\hline Fruit needs more advertising/promotion & 19 & 25.3 & 3,764 & 24.8 \\
\hline Fruit needs in-store demonstrations & 8 & 10.7 & 937 & 6.2 \\
\hline More P.O.P. material is needed & 2 & 2.7 & 800 & 5.3 \\
\hline Retailer education about fruit is needed & 4 & 5.3 & 736 & 4.9 \\
\hline Papaya has received a lot of promotion & 1 & 1.3 & 187 & 1.2 \\
\hline
\end{tabular}

\footnotetext{
${ }^{a}$ Percentages are based upon a total of 75 firms.

${ }^{b}$ Percentages are based upon a total of 15,155 stores.

$c$ Data not reported to avoid disclosure.
} 
Appendix Table C-10. Chainstore produce executives' comments on passion fruit, 75 firms, 30 cities.

\begin{tabular}{|c|c|c|c|c|}
\hline \multirow[t]{2}{*}{ Buyers' Comments } & \multicolumn{2}{|c|}{ Firms } & \multicolumn{2}{|c|}{ Stores } \\
\hline & (Number) & (Percent) ${ }^{a}$ & (Number) & (Percent) ${ }^{b}$ \\
\hline \multicolumn{5}{|l|}{ Performance/Demand } \\
\hline \multicolumn{5}{|l|}{ Positive: } \\
\hline Fruit is selling ok & 11 & 14.7 & 1,683 & 11.1 \\
\hline Sales are improving & 1 & 1.3 & 390 & 2.6 \\
\hline \multicolumn{5}{|l|}{ Negative: } \\
\hline Fruit is selling poorly & 34 & 45.3 & 6,235 & 41.1 \\
\hline Low demand for fruit & 15 & 20.0 & 3,078 & 20.3 \\
\hline Carry only on special order & 9 & 12.0 & 2,906 & 19.2 \\
\hline Not carried- no demand & 10 & 13.3 & 1,480 & 9.8 \\
\hline Not carried- did at one time; poor seller & 3 & 4.0 & 607 & 4.0 \\
\hline Not carried- unknown to customer & 1 & 1.3 & 260 & 1.7 \\
\hline Carry very few of this fruit & 1 & 1.3 & 147 & 1.0 \\
\hline \multicolumn{5}{|l|}{ Pricing } \\
\hline Lower prices/fruit is too expensive & 14 & 18.7 & 2,308 & 15.2 \\
\hline \multicolumn{5}{|l|}{ Fruit Characteristics/Quality/Pack } \\
\hline Fruit is unattractive & 5 & 6.7 & 801 & 5.3 \\
\hline Appearance/quality very important & 3 & 4.0 & 290 & 1.9 \\
\hline People are unsure when fruit is ripe & 2 & 2.7 & 194 & 1.3 \\
\hline \multicolumn{5}{|l|}{ Supply Issues } \\
\hline Supplies of fruit are inconsistent/unreliable & 3 & 4.0 & 851 & 5.6 \\
\hline Season is too short- extend if possible & 1 & 1.3 & 187 & 1.2 \\
\hline \multicolumn{5}{|l|}{ Consumer Markets } \\
\hline Anglos are unfamiliar with fruit & 3 & 4.0 & 1,152 & 7.6 \\
\hline High income market item & 6 & 8.0 & 814 & 5.4 \\
\hline Demographically mixed market item & 1 & 1.3 & 650 & 4.3 \\
\hline Hispanic market area- too expensive & 4 & 5.3 & 474 & 3.1 \\
\hline Ethnic market item & 1 & 1.3 & 370 & 2.4 \\
\hline \multicolumn{5}{|l|}{ Advertising and Promotion } \\
\hline Consumer education about fruit is needed & 32 & 42.7 & 6,335 & 41.8 \\
\hline Fruit needs more advertising/promotion & 14 & 18.7 & 2,399 & 15.8 \\
\hline Retailer education about fruit is needed & 4 & 5.3 & 736 & 4.9 \\
\hline Fruit needs in-store demonstrations & 5 & 6.7 & 460 & 3.0 \\
\hline More P.O.P. material is needed & 1 & 1.3 & 60 & 0.4 \\
\hline
\end{tabular}

a Percentages are based upon a total of 75 firms.

$b$ Percentages are based upon a total of 15,155 stores.

$c$ Data not reported to avoid disclosure. 
Appendix Table C-11. Chainstore produce executives' comments on sugar apple, 75 firms, 30 cities.

\begin{tabular}{|c|c|c|c|c|}
\hline \multirow[t]{2}{*}{ Buyers' Comments } & \multicolumn{2}{|c|}{ Firms } & \multicolumn{2}{|c|}{ Stores } \\
\hline & (Number) & (Percent) $^{a}$ & (Number) & ${ }_{\text {(Percent) }}^{b}$ \\
\hline \multicolumn{5}{|l|}{ Performance/Demand } \\
\hline \multicolumn{5}{|l|}{ Positive: } \\
\hline Fruit is selling well & 1 & 1.3 & 149 & 1.0 \\
\hline \multicolumn{5}{|l|}{ Negative: } \\
\hline Not carried- unknown to buyer & 24 & 32.0 & 5,454 & 36.0 \\
\hline Not carried- no demand & 20 & 26.7 & 3,407 & 22.5 \\
\hline Not carried- unknown to customer & 12 & 16.0 & 2,823 & 18.6 \\
\hline Low demand for fruit & 4 & 5.3 & 1,025 & 6.8 \\
\hline Carry only on special order & 4 & 5.3 & 760 & 5.0 \\
\hline Fruit is selling poorly & 5 & 6.7 & 556 & 3.7 \\
\hline Not carried- did at one time; poor seller & 3 & 4.0 & 414 & 2.7 \\
\hline Carry very few of this fruit & 1 & 1.3 & 147 & 1.0 \\
\hline \multicolumn{5}{|l|}{ Pricing } \\
\hline Lower prices/fruit is too expensive & 7 & 9.3 & 1,813 & 12.0 \\
\hline \multicolumn{5}{|l|}{ Fruit Characteristics/Quality/Pack } \\
\hline Appearance/quality very important & 2 & 2.7 & 210 & 1.4 \\
\hline \multicolumn{5}{|l|}{ Supply Issues } \\
\hline Supplies of fruit are inconsistent/unreliable & 1 & 1.3 & 390 & 2.6 \\
\hline Season is too short- extend if possible & 1 & 1.3 & 187 & 1.2 \\
\hline \multicolumn{5}{|l|}{$\underline{\text { Consumer Markets }}$} \\
\hline Anglos are unfamiliar with fruit & 3 & 4.0 & 1,152 & 7.6 \\
\hline Hispanic market area- too expensive & 3 & 4.0 & 363 & 2.4 \\
\hline High income market item & 1 & 1.3 & 90 & 0.6 \\
\hline Demographically mixed market item & 1 & 1.3 & 125 & 0.8 \\
\hline \multicolumn{5}{|l|}{ Advertising and Promotion } \\
\hline Consumer education about fruit is needed & 19 & 25.3 & 3,403 & 22.5 \\
\hline Fruit needs more advertising/promotion & 13 & 17.3 & 2,392 & 15.8 \\
\hline Retailer education about fruit is needed & 4 & 5.3 & 736 & 4.9 \\
\hline Fruit needs in-store demonstrations & 5 & 6.7 & 460 & 3.0 \\
\hline
\end{tabular}

${ }^{a}$ Percentages are based upon a total of 75 firms.

${ }^{b}$ Percentages are based upon a total of 15,155 stores.

$c$ Data not reported to avoid disclosure. 
Appendix Table D-1. Phytosanitary restrictions resulting from the Caribbean Fruit Fly on selected tropical fruit shipments to California, Texas and Arizona.

\begin{tabular}{lll}
\hline \hline Fruit & Shipments allowed & Comment \\
\hline Atemoya & No & No approved treatment \\
Specialty bananas & Yes & Not a host plant \\
Carambola & Yes & Must be cold treated, 12 days @ 34 degrees F. \\
Guava & Yes & How water treated, 35 minutes at 46.1 degrees C. \\
Lychee & Yes & No treatment required for commercially produced fruit \\
Longan & Yes & No treatment required for commercially produced fruit \\
Mamey sapote & Yes & Not a host plant \\
Mango & Yes & Hot water treated, various times and temperatures depending on size \\
Papaya & Yes & Hot water treatment required \\
Passion fruit & No & No approved treatment \\
Sugar apple & No & No approved treatment \\
\hline
\end{tabular}

${ }^{\text {a }}$ Sources of information include the Arizona, California, Florida and Texas Departments of Agriculture.

b Shipment of Mamey sapote may not enter California, however, they may enter Texas and Arizona. 
Appendix Table D-2. Sales trends reported by specialty produce wholesalers for selected tropical fruits by U.S.

region.

\begin{tabular}{|c|c|c|c|c|c|c|c|c|}
\hline \multirow[b]{3}{*}{ Fruit/Region } & \multirow[b]{3}{*}{$a$} & \multirow[b]{3}{*}{ Number reporting a trend } & \multicolumn{6}{|c|}{ Trend } \\
\hline & & & \multicolumn{2}{|c|}{ Down } & \multicolumn{2}{|c|}{ Stable } & \multicolumn{2}{|c|}{$\mathrm{Up}$} \\
\hline & & & Number & Percent & Number & Percent & Number & Percent \\
\hline \multicolumn{9}{|l|}{ Atemoya } \\
\hline Eastern & & 14 & 2 & 14.3 & 9 & 64.3 & 3 & 21.4 \\
\hline Western & & 4 & 0 & 0.0 & 3 & 75.0 & 1 & 25.0 \\
\hline Overall & & 18 & 2 & 11.1 & 12 & 67.7 & 4 & 22.2 \\
\hline \multicolumn{9}{|c|}{ Specialty bananas } \\
\hline Eastern & & 17 & 1 & 5.9 & 9 & 52.3 & 7 & 41.2 \\
\hline Western & & 22 & 0 & 0.0 & 10 & 45.4 & 12 & 54.6 \\
\hline Overall & & 39 & 1 & 2.6 & 19 & 48.7 & 19 & 48.7 \\
\hline \multicolumn{9}{|c|}{ Carambola $\quad b$} \\
\hline Eastern & & 37 & 0 & 0.0 & 11 & 29.7 & 26 & 70.3 \\
\hline Western & & 14 & 1 & 7.1 & 7 & 50.0 & 6 & 42.9 \\
\hline Overall & & 51 & 1 & 2.0 & 18 & 35.3 & 32 & 62.7 \\
\hline \multicolumn{9}{|l|}{ Guava } \\
\hline Eastern & & 23 & 2 & 8.7 & 14 & 60.9 & 7 & 30.4 \\
\hline Western & & 23 & 2 & 8.7 & 13 & 56.5 & 8 & 34.8 \\
\hline Overall & & 46 & 4 & 8.7 & 27 & 58.7 & 15 & 32.6 \\
\hline Lychee & $b$ & & & & & & & \\
\hline Eastern & & 28 & 1 & 3.6 & 19 & 67.9 & 8 & 28.6 \\
\hline Western & & 19 & 3 & 15.8 & 7 & 36.8 & 9 & 47.4 \\
\hline Overall & & 47 & 4 & 8.5 & 26 & 55.3 & 17 & 36.2 \\
\hline \multicolumn{9}{|l|}{ Longan } \\
\hline Eastern & & 10 & 0 & 0.0 & 6 & 60.0 & 4 & 40.0 \\
\hline Western & & 6 & 0 & 0.0 & 3 & 50.0 & 3 & 50.0 \\
\hline Overall & & 16 & 0 & 0.0 & 9 & 56.2 & 7 & 43.8 \\
\hline \multicolumn{9}{|l|}{ Mamey sapote } \\
\hline Eastern & & 14 & 1 & 7.1 & 9 & 64.3 & 4 & 28.6 \\
\hline Western & & 7 & 2 & 28.6 & 3 & 42.9 & 2 & 28.6 \\
\hline Overall & & 21 & 3 & 14.3 & 12 & 57.1 & 6 & 28.6 \\
\hline \multicolumn{9}{|l|}{ Mango } \\
\hline Eastern & & 62 & 4 & 6.4 & 14 & 22.6 & 44 & 71.0 \\
\hline Western & & 69 & 9 & 13.0 & 15 & 21.7 & 45 & 65.2 \\
\hline Overall & & 131 & 13 & 9.9 & 29 & 22.1 & 89 & 67.9 \\
\hline \multicolumn{9}{|l|}{ Papaya } \\
\hline Eastern & & 51 & 3 & 5.9 & 14 & 27.4 & 34 & 66.7 \\
\hline Western & & 63 & 7 & 11.1 & 22 & 34.9 & 34 & 54.0 \\
\hline Overall & & 114 & 10 & 8.8 & 36 & 31.6 & 68 & 59.6 \\
\hline \multicolumn{9}{|c|}{ Passion fruit $b$} \\
\hline Eastern & & 28 & 2 & 7.1 & 21 & 75.0 & 5 & 17.9 \\
\hline Western & & 15 & 0 & 0.0 & 6 & 40.0 & 9 & 60.0 \\
\hline Overall & & 43 & 2 & 4.7 & 27 & 62.8 & 14 & 32.6 \\
\hline \multicolumn{9}{|l|}{ Sugar apple } \\
\hline Eastern & & 7 & 0 & 0.0 & 6 & 85.7 & 1 & 14.3 \\
\hline Western & & 1 & 0 & 0.0 & 1 & 100.0 & 0 & 0.0 \\
\hline Overall & & 8 & 0 & 0.0 & 7 & 87.5 & 1 & 12.5 \\
\hline
\end{tabular}


Appendix Table D-3. Wholesalers' sources of specialty tropical fruits, by fruit.

\begin{tabular}{|c|c|c|c|c|c|c|c|c|c|c|c|c|c|}
\hline $\begin{array}{l}\text { Wholesaler } \\
\text { location }\end{array}$ & Fruit & Source 1 & Percent & Source 2 & Percent & Source 3 & Percent & Source 4 & Percent & Source 5 & Percent & Source 6 & Percent \\
\hline $\mathrm{CA}$ & Atemoya & Florida & 100 & & & & & & & & & & \\
\hline $\mathrm{CA}$ & Atemoya & unknown & 100 & & & & & & & & & & \\
\hline $\mathrm{CA}$ & Atemoya & Florida & 50 & California & 50 & & & & & & & & \\
\hline FL & Atemoya & Florida & 100 & & & & & & & & & & \\
\hline FL & Atemoya & Florida & n.a. & Mexico & n.a. & & & & & & & & \\
\hline FL & Atemoya & Florida & 100 & & & & & & & & & & \\
\hline $\mathrm{IL}$ & Atemoya & California & 100 & & & & & & & & & & \\
\hline $\mathrm{IL}$ & Atemoya & Florida & 100 & & & & & & & & & & \\
\hline IN & Atemoya & Florida & 90 & unknown & 10 & & & & & & & & \\
\hline MA & Atemoya & S. America & 100 & & & & & & & & & & \\
\hline MA & Atemoya & Florida & 100 & & & & & & & & & & \\
\hline MI & Atemoya & Florida & 95 & unknown & 5 & & & & & & & & \\
\hline MI & Atemoya & unknown & 100 & & & & & & & & & & \\
\hline NJ & Atemoya & unknown & 100 & & & & & & & & & & \\
\hline NY & Atemoya & Florida & 100 & & & & & & & & & & \\
\hline NY & Atemoya & Florida & 100 & & & & & & & & & & \\
\hline PA & Atemoya & unknown & 100 & & & & & & & & & & \\
\hline $\mathrm{TX}$ & Atemoya & Florida & 100 & & & & & & & & & & \\
\hline $\mathrm{AZ}$ & Banana & Mexico & 75 & Phillippines & 13 & S. America & 13 & & & & & & \\
\hline $\mathrm{AZ}$ & Banana & unknown & 100 & & & & & & & & & & \\
\hline $\mathrm{CA}$ & Banana & unknown & 100 & & & & & & & & & & \\
\hline $\mathrm{CA}$ & Banana & Mexico & 100 & & & & & & & & & & \\
\hline $\mathrm{CA}$ & Banana & unknown & 100 & & & & & & & & & & \\
\hline $\mathrm{CA}$ & Banana & Mexico & 100 & & & & & & & & & & \\
\hline $\mathrm{CA}$ & Banana & Ecuador & 90 & Mexico & 10 & & & & & & & & \\
\hline $\mathrm{CA}$ & Banana & Guatemala & 100 & & & & & & & & & & \\
\hline $\mathrm{CA}$ & Banana & unknown & 100 & & & & & & & & & & \\
\hline $\mathrm{CA}$ & Banana & Ecuador & 70 & Mexico & 30 & & & & & & & & \\
\hline $\mathrm{CA}$ & Banana & Mexico & n.a. & Costa Rica & n.a. & & & & & & & & \\
\hline $\mathrm{CA}$ & Banana & Ecuador & 90 & Mexico & 10 & & & & & & & & \\
\hline $\mathrm{CA}$ & Banana & Ecuador & n.a. & Costa Rica & n.a. & Panama & n.a. & Guatemala & n.a. & & & & \\
\hline $\mathrm{CA}$ & Banana & Mexico & 100 & & & & & & & & & & \\
\hline $\mathrm{CA}$ & Banana & Ecuador & 100 & & & & & & & & & & \\
\hline $\mathrm{CA}$ & Banana & Ecuador & 100 & & & & & & & & & & \\
\hline $\mathrm{CA}$ & Banana & Ecuador & 100 & & & & & & & & & & \\
\hline $\mathrm{CA}$ & Banana & Mexico & 99 & Venezuela & 1 & & & & & & & & \\
\hline $\mathrm{CA}$ & Banana & S. America & 100 & & & & & & & & & & \\
\hline $\mathrm{CA}$ & Banana & Mexico & 100 & & & & & & & & & & \\
\hline FL & Banana & Florida & 5 & S. America & 95 & & & & & & & & \\
\hline FL & Banana & unknown & 100 & & & & & & & & & & \\
\hline FL & Banana & Costa Rica & n.a. & Dominican & n.a. & Honduras & n.a. & & & & & & \\
\hline FL & Banana & unknown & 100 & & & & & & & & & & \\
\hline FL & Banana & Venezuela & 100 & & & & & & & & & & \\
\hline FL & Banana & Venezuela & 100 & & & & & & & & & & \\
\hline $\mathrm{IL}$ & Banana & Florida & n.a. & California & n.a. & & & & & & & & \\
\hline $\mathrm{IL}$ & Banana & California & 100 & & & & & & & & & & \\
\hline IN & Banana & Florida & 90 & unknown & 10 & & & & & & & & \\
\hline MA & Banana & unknown & 100 & & & & & & & & & & \\
\hline MA & Banana & Puerto Rico & 80 & Costa Rica & 20 & & & & & & & & \\
\hline MI & Banana & Costa Rica & 100 & & & & & & & & & & \\
\hline NJ & Banana & Honduras & 100 & & & & & & & & & & \\
\hline NY & Banana & Ecuador & 100 & & & & & & & & & & \\
\hline NY & Banana & Ecuador & 100 & & & & & & & & & & \\
\hline NY & Banana & Ecuador & 100 & & & & & & & & & & \\
\hline NY & Banana & Honduras & 100 & & & & & & & & & & \\
\hline $\mathrm{TX}$ & Banana & Mexico & 100 & & & & & & & & & & \\
\hline TX & Banana & Ecuador & 100 & & & & & & & & & & \\
\hline
\end{tabular}


Appendix Table D-3 (continued). Wholesalers' sources of specialty tropical fruits, by fruit.

\begin{tabular}{|c|c|c|c|c|c|c|c|c|c|c|c|c|c|}
\hline $\begin{array}{l}\text { Wholesaler } \\
\text { location }\end{array}$ & Fruit & Source 1 & Percent & Source 2 & Percent & Source 3 & Percent & Source 4 & Percent & Source 5 & Percent & Source 6 & Percent \\
\hline $\mathrm{AZ}$ & Carambola & California & 25 & Florida & 50 & Hawaii & 25 & & & & & & \\
\hline $\mathrm{CA}$ & Carambola & Florida & 80 & Hawaii & 20 & & & & & & & & \\
\hline $\mathrm{CA}$ & Carambola & Florida & 99 & California & 1 & & & & & & & & \\
\hline $\mathrm{CA}$ & Carambola & Florida & 80 & Hawaii & 20 & & & & & & & & \\
\hline $\mathrm{CA}$ & Carambola & Florida & 90 & Hawaii & 10 & & & & & & & & \\
\hline $\mathrm{CA}$ & Carambola & Malaysia & 100 & & & & & & & & & & \\
\hline $\mathrm{CA}$ & Carambola & Florida & 90 & Hawaii & 10 & & & & & & & & \\
\hline $\mathrm{CA}$ & Carambola & Florida & 100 & & & & & & & & & & \\
\hline $\mathrm{CA}$ & Carambola & unknown & 100 & & & & & & & & & & \\
\hline $\mathrm{CA}$ & Carambola & unknown & 100 & & & & & & & & & & \\
\hline $\mathrm{CA}$ & Carambola & unknown & 100 & & & & & & & & & & \\
\hline $\mathrm{CA}$ & Carambola & Florida & 100 & & & & & & & & & & \\
\hline $\mathrm{CA}$ & Carambola & Florida & 100 & & & & & & & & & & \\
\hline FL & Carambola & Florida & 100 & & & & & & & & & & \\
\hline FL & Carambola & Florida & 100 & & & & & & & & & & \\
\hline FL & Carambola & Florida & 100 & & & & & & & & & & \\
\hline FL & Carambola & Florida & 100 & & & & & & & & & & \\
\hline FL & Carambola & Florida & n.a. & Mexico & n.a. & & & & & & & & \\
\hline FL & Carambola & Florida & 100 & & & & & & & & & & \\
\hline FL & Carambola & Florida & 100 & & & & & & & & & & \\
\hline FL & Carambola & Florida & 100 & & & & & & & & & & \\
\hline FL & Carambola & Florida & 100 & & & & & & & & & & \\
\hline FL & Carambola & Florida & 100 & & & & & & & & & & \\
\hline FL & Carambola & Florida & 100 & & & & & & & & & & \\
\hline GA & Carambola & Florida & 100 & & & & & & & & & & \\
\hline IL & Carambola & Florida & 100 & & & & & & & & & & \\
\hline IL & Carambola & Florida & 100 & & & & & & & & & & \\
\hline IL & Carambola & Florida & 100 & & & & & & & & & & \\
\hline IN & Carambola & Florida & 100 & & & & & & & & & & \\
\hline MA & Carambola & Florida & 100 & & & & & & & & & & \\
\hline MA & Carambola & unknown & 100 & & & & & & & & & & \\
\hline MA & Carambola & Florida & 100 & & & & & & & & & & \\
\hline MI & Carambola & Florida & 100 & & & & & & & & & & \\
\hline MI & Carambola & Florida & 100 & & & & & & & & & & \\
\hline MI & Carambola & Florida & 100 & & & & & & & & & & \\
\hline MN & Carambola & Florida & 100 & & & & & & & & & & \\
\hline NJ & Carambola & Florida & 90 & California & 10 & & & & & & & & \\
\hline NJ & Carambola & Florida & 100 & & & & & & & & & & \\
\hline NY & Carambola & S. America & 100 & & & & & & & & & & \\
\hline NY & Carambola & S. America & 100 & & & & & & & & & & \\
\hline NY & Carambola & Florida & 100 & & & & & & & & & & \\
\hline NY & Carambola & unknown & 100 & & & & & & & & & & \\
\hline NY & Carambola & Florida & 100 & & & & & & & & & & \\
\hline NY & Carambola & Florida & 100 & & & & & & & & & & \\
\hline NY & Carambola & Florida & 100 & & & & & & & & & & \\
\hline PA & Carambola & Florida & 100 & & & & & & & & & & \\
\hline PA & Carambola & Florida & 100 & & & & & & & & & & \\
\hline PA & Carambola & Florida & 100 & & & & & & & & & & \\
\hline PA & Carambola & Florida & 100 & & & & & & & & & & \\
\hline SC & Carambola & Florida & 90 & imports & 10 & & & & & & & & \\
\hline $\mathrm{TN}$ & Carambola & Florida & 100 & & & & & & & & & & \\
\hline $\mathrm{TX}$ & Carambola & Florida & 100 & & & & & & & & & & \\
\hline $\mathrm{AZ}$ & Guava & unknown & 100 & & & & & & & & & & \\
\hline $\mathrm{AZ}$ & Guava & unknown & 100 & & & & & & & & & & \\
\hline $\mathrm{CA}$ & Guava & California & 100 & & & & & & & & & & \\
\hline $\mathrm{CA}$ & Guava & Mexico & n.a. & N. Zealand & n.a. & & & & & & & & \\
\hline $\mathrm{CA}$ & Guava & Mexico & 100 & & & & & & & & & & \\
\hline $\mathrm{CA}$ & Guava & Mexico & n.a. & California & n.a. & & & & & & & & \\
\hline $\mathrm{CA}$ & Guava & Mexico & 40 & Florida & 30 & California & 30 & & & & & & \\
\hline $\mathrm{CA}$ & Guava & unknown & 100 & & & & & & & & & & \\
\hline
\end{tabular}


Appendix Table D-3 (continued). Wholesalers' sources of specialty tropical fruits, by fruit.

\begin{tabular}{|c|c|c|c|c|c|c|c|c|c|c|c|c|c|}
\hline $\begin{array}{l}\text { Wholesaler } \\
\text { location }\end{array}$ & Fruit & Source 1 & Percent & Source 2 & Percent & Source 3 & Percent & Source 4 & Percent & Source 5 & Percent & Source 6 & Percent \\
\hline $\mathrm{CA}$ & Guava & N. Zealand & 100 & & & & & & & & & & \\
\hline $\mathrm{CA}$ & Guava & California & 100 & & & & & & & & & & \\
\hline $\mathrm{CA}$ & Guava & unknown & 100 & & & & & & & & & & \\
\hline $\mathrm{CA}$ & Guava & unknown & 100 & & & & & & & & & & \\
\hline $\mathrm{CA}$ & Guava & Mexico & 100 & & & & & & & & & & \\
\hline CA & Guava & Florida & 75 & Mexico & 25 & & & & & & & & \\
\hline $\mathrm{CA}$ & Guava & California & 100 & & & & & & & & & & \\
\hline $\mathrm{CA}$ & Guava & California & 100 & & & & & & & & & & \\
\hline $\mathrm{CA}$ & Guava & California & 100 & & & & & & & & & & \\
\hline CA & Guava & California & 70 & N. Zealand & 30 & & & & & & & & \\
\hline $\mathrm{CA}$ & Guava & California & 95 & Florida & 5 & & & & & & & & \\
\hline CA & Guava & California & 40 & N. Zealand & 60 & & & & & & & & \\
\hline FL & Guava & Florida & 100 & & & & & & & & & & \\
\hline FL & Guava & Florida & 100 & & & & & & & & & & \\
\hline FL & Guava & Florida & 100 & & & & & & & & & & \\
\hline FL & Guava & Florida & n.a. & Mexico & n.a. & & & & & & & & \\
\hline FL & Guava & Florida & 100 & & & & & & & & & & \\
\hline FL & Guava & Florida & 100 & & & & & & & & & & \\
\hline FL & Guava & Florida & 100 & & & & & & & & & & \\
\hline FL & Guava & Florida & 100 & & & & & & & & & & \\
\hline IL & Guava & Florida & 10 & California & 50 & N. Zealand & 40 & & & & & & \\
\hline IN & Guava & Florida & 90 & unknown & 10 & & & & & & & & \\
\hline MA & Guava & Florida & 100 & & & & & & & & & & \\
\hline MA & Guava & N. Zealand & 100 & & & & & & & & & & \\
\hline MI & Guava & Florida & 100 & & & & & & & & & & \\
\hline MI & Guava & Hawaii & 90 & Florida & 10 & & & & & & & & \\
\hline MI & Guava & unknown & 100 & & & & & & & & & & \\
\hline $\mathrm{NJ}$ & Guava & unknown & 100 & & & & & & & & & & \\
\hline NV & Guava & unknown & 100 & & & & & & & & & & \\
\hline NY & Guava & unknown & 100 & & & & & & & & & & \\
\hline NY & Guava & Florida & 100 & & & & & & & & & & \\
\hline NY & Guava & unknown & 100 & & & & & & & & & & \\
\hline NY & Guava & Florida & 100 & & & & & & & & & & \\
\hline NY & Guava & Guatemala & 100 & & & & & & & & & & \\
\hline NY & Guava & Florida & 100 & & & & & & & & & & \\
\hline PA & Guava & Florida & 100 & & & & & & & & & & \\
\hline PA & Guava & Mexico & 100 & & & & & & & & & & \\
\hline $\mathrm{TX}$ & Guava & Florida & 100 & & & & & & & & & & \\
\hline $\mathrm{TX}$ & Guava & unknown & 100 & & & & & & & & & & \\
\hline $\mathrm{AZ}$ & Lychee & California & 100 & & & & & & & & & & \\
\hline $\mathrm{CA}$ & Lychee & Mexico & 100 & & & & & & & & & & \\
\hline $\mathrm{CA}$ & Lychee & Florida & 60 & Mexico & 40 & & & & & & & & \\
\hline CA & Lychee & Florida & 20 & Thailand & 80 & & & & & & & & \\
\hline $\mathrm{CA}$ & Lychee & Israel & 10 & Mexico & 10 & Thailand & 10 & Florida & 70 & & & & \\
\hline $\mathrm{CA}$ & Lychee & Mexico & 100 & & & & & & & & & & \\
\hline CA & Lychee & Mexico & 100 & & & & & & & & & & \\
\hline $\mathrm{CA}$ & Lychee & Florida & 100 & & & & & & & & & & \\
\hline $\mathrm{CA}$ & Lychee & Mexico & 100 & & & & & & & & & & \\
\hline $\mathrm{CA}$ & Lychee & Mexico & 75 & Israel & 25 & & & & & & & & \\
\hline CA & Lychee & unknown & 100 & & & & & & & & & & \\
\hline $\mathrm{CA}$ & Lychee & unknown & 100 & & & & & & & & & & \\
\hline $\mathrm{CA}$ & Lychee & unknown & 100 & & & & & & & & & & \\
\hline $\mathrm{CA}$ & Lychee & Austrailia & n.a. & N. Zealand & n.a. & & & & & & & & \\
\hline $\mathrm{CA}$ & Lychee & Mexico & 100 & & & & & & & & & & \\
\hline $\mathrm{CA}$ & Lychee & Mexico & 50 & Florida & 50 & & & & & & & & \\
\hline $\mathrm{CA}$ & Lychee & Mexico & 100 & & & & & & & & & & \\
\hline FL & Lychee & Florida & n.a. & Mexico & n.a. & & & & & & & & \\
\hline FL & Lychee & Florida & n.a. & Chile & n.a. & & & & & & & & \\
\hline FL & Lychee & Florida & 50 & Israel & 50 & & & & & & & & \\
\hline FL & Lychee & Florida & 100 & & & & & & & & & & \\
\hline FL & Lychee & Florida & 100 & & & & & & & & & & \\
\hline FL & Lychee & Florida & 100 & & & & & & & & & & \\
\hline FL & Lychee & Florida & 100 & & & & & & & & & & \\
\hline
\end{tabular}


Appendix Table D-3 (continued). Wholesalers' sources of specialty tropical fruits, by fruit.

\begin{tabular}{|c|c|c|c|c|c|c|c|c|c|c|c|c|c|}
\hline Wholesaler & & & & & & & & & & & & & \\
\hline $\begin{array}{c}\text { location } \\
\text { FL }\end{array}$ & $\begin{array}{c}\text { Fruit } \\
\text { Lychee }\end{array}$ & $\begin{array}{l}\text { Source } 1 \\
\text { Florida }\end{array}$ & $\begin{array}{c}\text { Percent } \\
100\end{array}$ & Source 2 & Percent & Source 3 & Percent & Source 4 & Percent & Source 5 & Percent & Source 6 & Percent \\
\hline FL & Lychee & Florida & 100 & & & & & & & & & & \\
\hline FL & Lychee & Florida & 100 & & & & & & & & & & \\
\hline FL & Lychee & Florida & 100 & & & & & & & & & & \\
\hline GA & Lychee & Florida & 100 & & & & & & & & & & \\
\hline IL & Lychee & Florida & 100 & & & & & & & & & & \\
\hline IL & Lychee & Florida & 60 & California & 40 & & & & & & & & \\
\hline IN & Lychee & Florida & 90 & unknown & 10 & & & & & & & & \\
\hline MA & Lychee & unknown & 100 & & & & & & & & & & \\
\hline MA & Lychee & Mexico & 100 & & & & & & & & & & \\
\hline MA & Lychee & Florida & 100 & & & & & & & & & & \\
\hline MI & Lychee & Florida & 100 & & & & & & & & & & \\
\hline MI & Lychee & Florida & 50 & Caribbean & 50 & & & & & & & & \\
\hline MI & Lychee & Florida & 95 & unknown & 5 & & & & & & & & \\
\hline $\mathrm{NJ}$ & Lychee & Hawaii & 100 & & & & & & & & & & \\
\hline NY & Lychee & Florida & 100 & & & & & & & & & & \\
\hline NY & Lychee & Chile & 100 & & & & & & & & & & \\
\hline NY & Lychee & Florida & 100 & & & & & & & & & & \\
\hline NY & Lychee & Mexico & 50 & Florida & 50 & & & & & & & & \\
\hline NY & Lychee & unknown & 100 & & & & & & & & & & \\
\hline PA & Lychee & unknown & 100 & & & & & & & & & & \\
\hline PA & Lychee & unknown & 100 & & & & & & & & & & \\
\hline PA & Lychee & Florida & 35 & Israel & 65 & & & & & & & & \\
\hline TX & Lychee & Florida & 100 & & & & & & & & & & \\
\hline $\mathrm{AZ}$ & Longan & California & 100 & & & & & & & & & & \\
\hline $\mathrm{CA}$ & Longan & SE Asia & 100 & & & & & & & & & & \\
\hline $\mathrm{CA}$ & Longan & Florida & 100 & & & & & & & & & & \\
\hline $\mathrm{CA}$ & Longan & Florida & 100 & & & & & & & & & & \\
\hline $\mathrm{CA}$ & Longan & Mexico & 100 & & & & & & & & & & \\
\hline FL & Longan & Florida & 100 & & & & & & & & & & \\
\hline FL & Longan & Florida & 100 & & & & & & & & & & \\
\hline IL & Longan & Florida & 100 & & & & & & & & & & \\
\hline IN & Longan & Florida & 90 & unknown & 10 & & & & & & & & \\
\hline MA & Longan & Florida & 100 & & & & & & & & & & \\
\hline MA & Longan & Florida & 100 & & & & & & & & & & \\
\hline NY & Longan & unknown & 100 & & & & & & & & & & \\
\hline NY & Longan & Florida & 100 & & & & & & & & & & \\
\hline NY & Longan & unknown & 100 & & & & & & & & & & \\
\hline $\mathrm{TX}$ & Longan & Florida & 100 & & & & & & & & & & \\
\hline $\mathrm{AZ}$ & Mamey Sapote & unknown & 100 & & & & & & & & & & \\
\hline $\mathrm{CA}$ & Mamey Sapote & Costa Rica & 100 & & & & & & & & & & \\
\hline $\mathrm{CA}$ & Mamey Sapote & unknown & 100 & & & & & & & & & & \\
\hline CA & Mamey Sapote & Mexico & 100 & & & & & & & & & & \\
\hline FL & Mamey Sapote & Florida & 100 & & & & & & & & & & \\
\hline FL & Mamey Sapote & Florida & n.a. & Mexico & n.a. & & & & & & & & \\
\hline FL & Mamey Sapote & Florida & 100 & & & & & & & & & & \\
\hline FL & Mamey Sapote & Florida & 100 & & & & & & & & & & \\
\hline FL & Mamey Sapote & Florida & 100 & & & & & & & & & & \\
\hline IL & Mamey Sapote & Florida & 100 & & & & & & & & & & \\
\hline IN & Mamey Sapote & Florida & 90 & unknown & 10 & & & & & & & & \\
\hline MA & Mamey Sapote & S. America & 50 & Mexico & 50 & & & & & & & & \\
\hline MA & Mamey Sapote & Florida & 100 & & & & & & & & & & \\
\hline MI & Mamey Sapote & Florida & 95 & unknown & 5 & & & & & & & & \\
\hline NY & Mamey Sapote & Florida & 100 & & & & & & & & & & \\
\hline NY & Mamey Sapote & Florida & 100 & & & & & & & & & & \\
\hline NY & Mamey Sapote & unknown & 100 & & & & & & & & & & \\
\hline PA & Mamey Sapote & unknown & 100 & & & & & & & & & & \\
\hline $\mathrm{TX}$ & Mamey Sapote & unknown & 100 & & & & & & & & & & \\
\hline $\mathrm{TX}$ & Mamey Sapote & Florida & 100 & & & & & & & & & & \\
\hline $\mathrm{TX}$ & Mamey Sapote & Florida & 100 & & & & & & & & & & \\
\hline
\end{tabular}


Appendix Table D-3 (continued). Wholesalers' sources of specialty tropical fruits, by fruit.

\begin{tabular}{|c|c|c|c|c|c|c|c|c|c|c|c|c|c|}
\hline Wholesaler & & & & & & & & & & & & & \\
\hline location & Fruit & Source 1 & Percent & Source 2 & Percent & Source 3 & Percent & Source 4 & Percent & Source 5 & Percent & Source 6 & Percent \\
\hline AZ & Mango & Mexico & $\begin{array}{l}100 \\
100\end{array}$ & & & & & & & & & & \\
\hline AZ & Mango & Mexico & 100 & & & & & & & & & & \\
\hline $\mathrm{AZ}$ & Mango & Mexico & 100 & & & & & & & & & & \\
\hline $\mathrm{AZ}$ & Mango & Mexico & 100 & & & & & & & & & & \\
\hline $\mathrm{AZ}$ & Mango & Mexico & 75 & Peru & 13 & Chile & 13 & & & & & & \\
\hline $\mathrm{AZ}$ & Mango & Mexico & 100 & & & & & & & & & & \\
\hline $\mathrm{CA}$ & Mango & Mexico & 100 & & & & & & & & & & \\
\hline CA & Mango & Brazil & 5 & Mexico & 95 & & & & & & & & \\
\hline $\mathrm{CA}$ & Mango & Mexico & 70 & Brazil & 30 & & & & & & & & \\
\hline $\mathrm{CA}$ & Mango & Mexico & 100 & & & & & & & & & & \\
\hline $\mathrm{CA}$ & Mango & Mexico & 100 & & & & & & & & & & \\
\hline $\mathrm{CA}$ & Mango & Mexico & 100 & & & & & & & & & & \\
\hline CA & Mango & Mexico & 100 & & & & & & & & & & \\
\hline CA & Mango & Mexico & 100 & & & & & & & & & & \\
\hline CA & Mango & Mexico & 100 & & & & & & & & & & \\
\hline $\mathrm{CA}$ & Mango & Mexico & 100 & & & & & & & & & & \\
\hline $\mathrm{CA}$ & Mango & Mexico & 100 & & & & & & & & & & \\
\hline CA & Mango & Mexico & 100 & & & & & & & & & & \\
\hline $\mathrm{CA}$ & Mango & Mexico & 80 & Brazil & 10 & Ecuador & 10 & & & & & & \\
\hline $\mathrm{CA}$ & Mango & Mexico & 100 & & & & & & & & & & \\
\hline CA & Mango & Mexico & 100 & & & & & & & & & & \\
\hline CA & Mango & Mexico & 100 & & & & & & & & & & \\
\hline $\mathrm{CA}$ & Mango & Mexico & 75 & Brazil & 13 & Peru & 13 & & & & & & \\
\hline $\mathrm{CA}$ & Mango & Mexico & 70 & Brazil & 10 & Ecuador & 10 & Peru & 10 & & & & \\
\hline CA & Mango & Mexico & 90 & Brazil & 5 & Peru & 5 & & & & & & \\
\hline $\mathrm{CA}$ & Mango & Mexico & 85 & S. America & 15 & & & & & & & & \\
\hline CA & Mango & unknown & 100 & & & & & & & & & & \\
\hline CA & Mango & unknown & 100 & & & & & & & & & & \\
\hline CA & Mango & S. America & 100 & & & & & & & & & & \\
\hline CA & Mango & Peru & 60 & Nicaragua & 10 & Ecuador & 30 & & & & & & \\
\hline CA & Mango & Peru & 25 & El Salvador & 13 & Brazil & 50 & Costa Rica & 13 & & & & \\
\hline CA & Mango & Peru & 100 & & & & & & & & & & \\
\hline $\mathrm{CA}$ & Mango & Mexico & 50 & unknown & 50 & & & & & & & & \\
\hline CA & Mango & Mexico & 60 & Peru & 20 & Brazil & 20 & & & & & & \\
\hline $\mathrm{CA}$ & Mango & Mexico & 90 & S. America & 10 & & & & & & & & \\
\hline $\mathrm{CA}$ & Mango & Mexico & 50 & Brazil & 17 & Peru & 17 & Ecuador & 17 & & & & \\
\hline CA & Mango & Mexico & 90 & Peru & 10 & & & & & & & & \\
\hline $\mathrm{CA}$ & Mango & Mexico & 70 & Peru & 30 & & & & & & & & \\
\hline $\mathrm{CA}$ & Mango & Mexico & 99 & N. Zealand & 1 & & & & & & & & \\
\hline $\mathrm{CA}$ & Mango & Mexico & n.a. & Guatemala & n.a. & & & & & & & & \\
\hline CA & Mango & Mexico & 80 & Florida & 20 & & & & & & & & \\
\hline $\mathrm{CA}$ & Mango & Mexico & 75 & Ecuador & 8 & Peru & 8 & Brazil & 8 & & & & \\
\hline CA & Mango & Mexico & 95 & Ecuador & 3 & Peru & 3 & & & & & & \\
\hline CA & Mango & Arizona & 100 & & & & & & & & & & \\
\hline CA & Mango & Mexico & 100 & & & & & & & & & & \\
\hline CA & Mango & Mexico & 100 & & & & & & & & & & \\
\hline CA & Mango & Mexico & 100 & & & & & & & & & & \\
\hline $\mathrm{CA}$ & Mango & Mexico & 100 & & & & & & & & & & \\
\hline CA & Mango & Guatemala & n.a. & Mexico & n.a. & & & & & & & & \\
\hline CA & Mango & Florida & 100 & & & & & & & & & & \\
\hline $\mathrm{CA}$ & Mango & Chile & 80 & Mexico & 20 & & & & & & & & \\
\hline CA & Mango & Brazil & 10 & Mexico & 60 & Peru & 10 & Columbia & 10 & Ecuador & 10 & & \\
\hline CA & Mango & Hawaii & 50 & Mexico & 50 & & & & & & & & \\
\hline $\mathrm{CA}$ & Mango & Mexico & 100 & & & & & & & & & & \\
\hline CA & Mango & Brazil & 10 & Mexico & 80 & Ecuador & 5 & Peru & 5 & & & & \\
\hline $\mathrm{CA}$ & Mango & Mexico & 100 & & & & & & & & & & \\
\hline FL & Mango & Florida & n.a. & Guatemala & n.a. & Mexico & n.a. & & & & & & \\
\hline FL & Mango & Venezuela & 30 & Haiti & 50 & Peru & 20 & & & & & & \\
\hline FL & Mango & Florida & 5 & Mexico & 60 & Venezuela & 20 & Brazil & 10 & Peru & 5 & & \\
\hline FL & Mango & Florida & 25 & Mexico & 20 & Brazil & 20 & Ecuador & 20 & Haiti & 5 & Peru & 10 \\
\hline FL & Mango & Mexico & 90 & Florida & 10 & & & & & & & & \\
\hline FL & Mango & Florida & 10 & Haiti & 30 & Mexico & 60 & & & & & & \\
\hline FL & Mango & Mexico & 15 & Guatemala & 30 & Peru & 20 & Brazil & 35 & & & & \\
\hline FL & Mango & Mexico & 50 & Peru & 10 & Nicaragua & 10 & Guatemala & 10 & Venezuela & 10 & Brazil & 10 \\
\hline
\end{tabular}


Appendix Table D-3 (continued). Wholesalers' sources of specialty tropical fruits, by fruit.

\begin{tabular}{|c|c|c|c|c|c|c|c|c|c|c|c|c|c|}
\hline $\begin{array}{l}\text { Wholesaler } \\
\text { location }\end{array}$ & Fruit & Source 1 & Percent & Source 2 & Percent & Source 3 & Percent & Source 4 & Percent & Source 5 & Percent & Source 6 & Percent \\
\hline FL & Mango & Florida & 75 & Arizona & 13 & Mexico & 13 & & & & & & \\
\hline FL & Mango & unknown & 100 & & & & & & & & & & \\
\hline FL & Mango & Florida & 100 & & & & & & & & & & \\
\hline FL & Mango & Florida & 100 & & & & & & & & & & \\
\hline FL & Mango & Florida & 10 & Venezuela & 20 & Mexico & 20 & Brazil & 50 & & & & \\
\hline FL & Mango & Venezuela & 50 & Haiti & 50 & & & & & & & & \\
\hline FL & Mango & C. America & n.a. & S. America & n.a. & & & & & & & & \\
\hline FL & Mango & St. Vincent & 35 & Guatemala & 25 & Haiti & 15 & $\begin{array}{l}\text { Peru } \\
\text { Puerto }\end{array}$ & 25 & & & & \\
\hline FL & Mango & Florida & 25 & Peru & 25 & Mexico & 25 & Rico & 25 & & & & \\
\hline FL & Mango & Mexico & 60 & Florida & 40 & & & & & & & & \\
\hline FL & Mango & Guatemala & 100 & & & & & & & & & & \\
\hline FL & Mango & Guatemala & 15 & Belize & 15 & S. America & 70 & & & & & & \\
\hline FL & Mango & Haiti & 100 & & & & & & & & & & \\
\hline FL & Mango & Haiti & 40 & Jamaica & 40 & Mexico & 10 & Florida & 10 & & & & \\
\hline GA & Mango & Mexico & 100 & & & & & & & & & & \\
\hline GA & Mango & Haiti & 50 & C. America & 25 & S. America & 25 & & & & & & \\
\hline IL & Mango & S. America & 100 & & & & & & & & & & \\
\hline IL & Mango & Mexico & 90 & S. America & 10 & & & & & & & & \\
\hline IL & Mango & Guatemala & 10 & Venezuela & 7 & Ecuador & 3 & Mexico & 80 & & & & \\
\hline IL & Mango & Mexico & 100 & & & & & & & & & & \\
\hline IL & Mango & Mexico & 75 & S. America & 25 & & & & & & & & \\
\hline IN & Mango & Florida & 90 & unknown & 10 & & & & & & & & \\
\hline MA & Mango & Haiti & 50 & Mexico & 40 & Florida & 10 & & & & & & \\
\hline MA & Mango & S. America & 70 & N. Zealand & 30 & & & & & & & & \\
\hline MA & Mango & Mexico & 100 & & & & & & & & & & \\
\hline MA & Mango & Venezuela & 10 & Brazil & 10 & Mexico & 50 & Haiti & 10 & Guatemala & 10 & Peru & 10 \\
\hline MD & Mango & Mexico & 100 & & & & & & & & & & \\
\hline MI & Mango & Mexico & 80 & unknown & 20 & & & & & & & & \\
\hline MI & Mango & Mexico & 95 & Brazil & 3 & Peru & 3 & & & & & & \\
\hline MI & Mango & Mexico & 75 & Florida & 25 & & & & & & & & \\
\hline MN & Mango & Mexico & 75 & Brazil & 13 & Haiti & 13 & & & & & & \\
\hline NJ & Mango & Haiti & n.a. & Mexico & n.a. & & & & & & & & \\
\hline $\mathrm{NJ}$ & Mango & Puerto Rico & 60 & Mexico & 10 & Haiti & 15 & Brazil & 15 & & & & \\
\hline NM & Mango & unknown & 100 & & & & & & & & & & \\
\hline NV & Mango & Guatemala & 80 & Mexico & 10 & Chile & 10 & & & & & & \\
\hline NY & Mango & Puerto Rico & 100 & & & & & & & & & & \\
\hline NY & Mango & Costa Rica & 100 & & & & & & & & & & \\
\hline NY & Mango & Mexico & 50 & unknown & 50 & & & & & & & & \\
\hline NY & Mango & Mexico & 15 & Venezuela & 15 & Haiti & 60 & Brazil & 10 & & & & \\
\hline NY & Mango & Mexico & 10 & Venezuela & 15 & Haiti & 73 & Florida & 2 & & & & \\
\hline NY & Mango & Mexico & 100 & & & & & & & & & & \\
\hline NY & Mango & Mexico & 50 & Brazil & 20 & Venezuela & 30 & & & & & & \\
\hline NY & Mango & Mexico & 100 & & & & & & & & & & \\
\hline NY & Mango & Mexico & 75 & Peru & 13 & Brazil & 13 & & & & & & \\
\hline NY & Mango & Mexico & 70 & Haiti & 30 & & & & & & & & \\
\hline NY & Mango & Florida & 100 & & & & & & & & & & \\
\hline NY & Mango & Mexico & 80 & Brazil & 20 & & & & & & & & \\
\hline NY & Mango & Florida & 100 & & & & & & & & & & \\
\hline NY & Mango & Mexico & 70 & Peru & 10 & Venezuela & 10 & Haiti & 10 & & & & \\
\hline NY & Mango & Ecuador & 5 & Brazil & 5 & Peru & 5 & Haiti & 40 & Mexico & 40 & Venezuela & 5 \\
\hline OR & Mango & Mexico & 100 & & & & & & & & & & \\
\hline PA & Mango & Venezuela & 10 & Guatemala & 10 & Florida & 40 & Haiti & 40 & & & & \\
\hline PA & Mango & Venezuela & 30 & Mexico & 60 & Peru & 5 & Brazil & 5 & & & & \\
\hline PA & Mango & Mexico & 25 & Venezuela & 25 & Guatemala & 25 & Brazil & 25 & & & & \\
\hline PA & Mango & Florida & 80 & Mexico & 20 & & & & & & & & \\
\hline PA & Mango & Mexico & 80 & Florida & 5 & Peru & 5 & Brazil & 5 & Guatemala & 5 & & \\
\hline $\mathrm{SC}$ & Mango & Florida & 90 & imports & 10 & & & & & & & & \\
\hline $\mathrm{TN}$ & Mango & Florida & 25 & C. America & 75 & & & & & & & & \\
\hline $\mathrm{TX}$ & Mango & Mexico & 100 & & & & & & & & & & \\
\hline TX & Mango & Mexico & 100 & & & & & & & & & & \\
\hline TX & Mango & Mexico & 100 & & & & & & & & & & \\
\hline TX & Mango & Mexico & 100 & & & & & & & & & & \\
\hline TX & Mango & Mexico & 100 & & & & & & & & & & \\
\hline
\end{tabular}


Appendix Table D-3 (continued). Wholesalers' sources of specialty tropical fruits, by fruit.

\begin{tabular}{|c|c|c|c|c|c|c|c|c|c|c|c|c|c|}
\hline $\begin{array}{l}\text { Wholesaler } \\
\text { location }\end{array}$ & Fruit & Source 1 & Percent & Source? & Percent & Source 3 & Percent & Source 4 & Percent & Source 5 & Percent & Source 6 & Percent \\
\hline $\mathrm{TX}$ & Mango & Texas & 100 & & 1. Tोetit & & & & 1 tercent & & 1 tectiot & & \\
\hline $\mathrm{TX}$ & Mango & Mexico & 100 & & & & & & & & & & \\
\hline $\mathrm{TX}$ & Mango & Mexico & 100 & & & & & & & & & & \\
\hline $\mathrm{TX}$ & Mango & Mexico & 70 & Brazil & 27 & Ecuador & 3 & & & & & & \\
\hline WA & Mango & Mexico & 75 & Florida & 25 & & & & & & & & \\
\hline $\mathrm{AZ}$ & Papaya & Hawaii & 90 & Mexico & 10 & & & & & & & & \\
\hline $\mathrm{AZ}$ & Papaya & Phillippines & 50 & Mexico & 50 & & & & & & & & \\
\hline $\mathrm{CA}$ & Papaya & unknown & 20 & Florida & 80 & & & & & & & & \\
\hline CA & Papaya & Hawaii & 100 & & & & & & & & & & \\
\hline CA & Papaya & Hawaii & 100 & & & & & & & & & & \\
\hline $\mathrm{CA}$ & Papaya & Mexico & 100 & & & & & & & & & & \\
\hline $\mathrm{CA}$ & Papaya & Mexico & 100 & & & & & & & & & & \\
\hline $\mathrm{CA}$ & Papaya & Hawaii & 100 & & & & & & & & & & \\
\hline $\mathrm{CA}$ & Papaya & Mexico & 100 & & & & & & & & & & \\
\hline $\mathrm{CA}$ & Papaya & Mexico & 100 & & & & & & & & & & \\
\hline $\mathrm{CA}$ & Papaya & Hawaii & 100 & & & & & & & & & & \\
\hline $\mathrm{CA}$ & Papaya & Hawaii & 100 & & & & & & & & & & \\
\hline CA & Papaya & Hawaii & 100 & & & & & & & & & & \\
\hline $\mathrm{CA}$ & Papaya & Hawaii & 100 & & & & & & & & & & \\
\hline $\mathrm{CA}$ & Papaya & Mexico & 100 & & & & & & & & & & \\
\hline $\mathrm{CA}$ & Papaya & Mexico & 100 & & & & & & & & & & \\
\hline $\mathrm{CA}$ & Papaya & Hawaii & 70 & Mexico & 30 & & & & & & & & \\
\hline $\mathrm{CA}$ & Papaya & Hawaii & 90 & Mexico & 10 & & & & & & & & \\
\hline $\mathrm{CA}$ & Papaya & Hawaii & 20 & Mexico & 80 & & & & & & & & \\
\hline CA & Papaya & Hawaii & 80 & C. America & 20 & & & & & & & & \\
\hline $\mathrm{CA}$ & Papaya & Mexico & 100 & & & & & & & & & & \\
\hline $\mathrm{CA}$ & Papaya & Mexico & 100 & & & & & & & & & & \\
\hline $\mathrm{CA}$ & Papaya & Hawaii & 100 & & & & & & & & & & \\
\hline $\mathrm{CA}$ & Papaya & Mexico & 100 & & & & & & & & & & \\
\hline $\mathrm{CA}$ & Papaya & Hawaii & 100 & & & & & & & & & & \\
\hline $\mathrm{CA}$ & Papaya & Hawaii & 100 & & & & & & & & & & \\
\hline $\mathrm{CA}$ & Papaya & Hawaii & 100 & & & & & & & & & & \\
\hline $\mathrm{CA}$ & Papaya & Hawaii & 100 & & & & & & & & & & \\
\hline $\mathrm{CA}$ & Papaya & Mexico & 70 & Hawaii & 30 & & & & & & & & \\
\hline CA & Papaya & Mexico & 100 & & & & & & & & & & \\
\hline $\mathrm{CA}$ & Papaya & Mexico & 85 & Hawaii & 15 & & & & & & & & \\
\hline CA & Papaya & Mexico & 50 & Hawaii & 50 & & & & & & & & \\
\hline $\mathrm{CA}$ & Papaya & Mexico & 33 & Hawaii & 67 & & & & & & & & \\
\hline $\mathrm{CA}$ & Papaya & Mexico & 100 & & & & & & & & & & \\
\hline $\mathrm{CA}$ & Papaya & Dominican & 100 & & & & & & & & & & \\
\hline $\mathrm{CA}$ & Papaya & unknown & 100 & & & & & & & & & & \\
\hline $\mathrm{CA}$ & Papaya & unknown & 100 & & & & & & & & & & \\
\hline $\mathrm{CA}$ & Papaya & Mexico & 100 & & & & & & & & & & \\
\hline $\mathrm{CA}$ & Papaya & Mexico & 100 & & & & & & & & & & \\
\hline $\mathrm{CA}$ & Papaya & Mexico & 100 & & & & & & & & & & \\
\hline $\mathrm{CA}$ & Papaya & Mexico & 100 & & & & & & & & & & \\
\hline $\mathrm{CA}$ & Papaya & Hawaii & 100 & & & & & & & & & & \\
\hline $\mathrm{CA}$ & Papaya & Mexico & 100 & & & & & & & & & & \\
\hline $\mathrm{CA}$ & Papaya & Mexico & 100 & & & & & & & & & & \\
\hline $\mathrm{CA}$ & Papaya & Mexico & 100 & & & & & & & & & & \\
\hline CA & Papaya & Mexico & 100 & & & & & & & & & & \\
\hline $\mathrm{CA}$ & Papaya & Mexico & 100 & & & & & & & & & & \\
\hline CA & Papaya & Mexico & 100 & & & & & & & & & & \\
\hline $\mathrm{CA}$ & Papaya & Hawaii & 100 & & & & & & & & & & \\
\hline FL & Papaya & Jamaica & 75 & Belize & 25 & & & & & & & & \\
\hline FL & Papaya & Jamaica & 100 & & & & & & & & & & \\
\hline FL & Papaya & Jamaica & 30 & Dominican & 70 & & & & & & & & \\
\hline FL & Papaya & Jamaica & 50 & Hawaii & 50 & & & & & & & & \\
\hline FL & Papaya & Jamaica & 90 & Hawaii & 10 & & & & & & & & \\
\hline FL & Papaya & Mexico & 50 & Jamaica & 50 & & & & & & & & \\
\hline FL & Papaya & Jamaica & 40 & Mexico & 20 & Dominican & 40 & & & & & & \\
\hline FL & Papaya & Jamaica & 100 & & & & & & & & & & \\
\hline FL & Papaya & Jamaica & 100 & & & & & & & & & & \\
\hline
\end{tabular}


Appendix Table D-3 (continued). Wholesalers' sources of specialty tropical fruits, by fruit.

\begin{tabular}{|c|c|c|c|c|c|c|c|c|c|c|c|c|c|}
\hline $\begin{array}{c}\text { Wholesaler } \\
\text { location }\end{array}$ & Fruit & Source 1 & Percent & Source 2 & Percent & Source 3 & Percent & Source 4 & Percent & Source 5 & Percent & Source 6 & Percent \\
\hline FL & Papaya & Bahamas & 100 & & & & & & & & & & \\
\hline $\mathrm{FL}$ & Papaya & Jamaica & 100 & & & & & & & & & & \\
\hline $\mathrm{FL}$ & Papaya & Dominican & 80 & Florida & 20 & & & & & & & & \\
\hline FL & Papaya & Florida & 100 & & & & & & & & & & \\
\hline $\mathrm{FL}$ & Papaya & Florida & 100 & & & & & & & & & & \\
\hline $\mathrm{FL}$ & Papaya & Dominican & 60 & Jamaica & 40 & & & & & & & & \\
\hline FL & Papaya & Dominican & n.a. & Guatemala & n.a. & Belize & n.a. & & & & & & \\
\hline FL & Papaya & Florida & n.a. & Mexico & n.a. & & & & & & & & \\
\hline $\mathrm{FL}$ & Papaya & Dominican & 100 & & & & & & & & & & \\
\hline $\mathrm{FL}$ & Papaya & Dominican & 100 & & & & & & & & & & \\
\hline FL & Papaya & Bahamas & 25 & Florida & 25 & Jamaica & 50 & & & & & & \\
\hline GA & Papaya & Jamaica & 100 & & & & & & & & & & \\
\hline IL & Papaya & Hawaii & 100 & & & & & & & & & & \\
\hline IL & Papaya & Hawaii & 5 & Jamaica & 75 & Mexico & 20 & & & & & & \\
\hline $\mathrm{IL}$ & Papaya & Costa Rica & 100 & & & & & & & & & & \\
\hline $\mathrm{IL}$ & Papaya & Jamaica & 80 & Dominican & 20 & & & & & & & & \\
\hline IN & Papaya & Florida & 90 & unknown & 10 & & & & & & & & \\
\hline MA & Papaya & Florida & 10 & Mexico & 90 & & & & & & & & \\
\hline MA & Papaya & Hawaii & 100 & & & & & & & & & & \\
\hline MA & Papaya & Hawaii & 100 & & & & & & & & & & \\
\hline MI & Papaya & Florida & 100 & & & & & & & & & & \\
\hline MI & Papaya & Hawaii & 95 & unknown & 5 & & & & & & & & \\
\hline MI & Papaya & Hawaii & 95 & Mexico & 3 & Caribbean & 3 & & & & & & \\
\hline MN & Papaya & Hawaii & 25 & Mexico & 25 & Jamaica & 50 & & & & & & \\
\hline NJ & Papaya & Hawaii & 50 & Jamaica & 50 & & & & & & & & \\
\hline NJ & Papaya & Hawaii & 75 & Puerto Rico & 25 & & & & & & & & \\
\hline NV & Papaya & Hawaii & 100 & & & & & & & & & & \\
\hline NY & Papaya & Jamaica & 65 & Hawaii & 35 & & & & & & & & \\
\hline NY & Papaya & Hawaii & 70 & Jamaica & 10 & Dominican & 10 & Belize & 10 & & & & \\
\hline NY & Papaya & Mexico & 100 & & & & & & & & & & \\
\hline NY & Papaya & Dominican & 100 & & & & & & & & & & \\
\hline NY & Papaya & Caribbean & 50 & Hawaii & 50 & & & & & & & & \\
\hline NY & Papaya & Belize & 70 & Jamaica & 15 & Dominican & 15 & & & & & & \\
\hline NY & Papaya & Mexico & 100 & & & & & & & & & & \\
\hline NY & Papaya & Mexico & 100 & & & & & & & & & & \\
\hline NY & Papaya & Mexico & 100 & & & & & & & & & & \\
\hline NY & Papaya & Hawaii & 100 & & & & & & & & & & \\
\hline NY & Papaya & Mexico & 100 & & & & & & & & & & \\
\hline OR & Papaya & Hawaii & 100 & & & & & & & & & & \\
\hline OR & Papaya & Hawaii & 100 & & & & & & & & & & \\
\hline PA & Papaya & Hawaii & 100 & & & & & & & & & & \\
\hline PA & Papaya & Jamaica & 75 & Dominican & 25 & & & & & & & & \\
\hline PA & Papaya & Hawaii & 33 & Belize & 33 & Jamaica & 33 & & & & & & \\
\hline $\mathrm{PA}$ & Papaya & Hawaii & 99 & S. America & 1 & & & & & & & & \\
\hline $\mathrm{SC}$ & Papaya & Florida & 90 & imports & 10 & & & & & & & & \\
\hline $\mathrm{TN}$ & Papaya & Florida & 25 & C. America & 75 & & & & & & & & \\
\hline TX & Papaya & Dominican & 50 & Jamaica & 50 & & & & & & & & \\
\hline $\mathrm{TX}$ & Papaya & Florida & 100 & & & & & & & & & & \\
\hline TX & Papaya & Mexico & 100 & & & & & & & & & & \\
\hline $\mathrm{TX}$ & Papaya & Texas & 100 & & & & & & & & & & \\
\hline $\mathrm{TX}$ & Papaya & unknown & 100 & & & & & & & & & & \\
\hline $\mathrm{TX}$ & Papaya & unknown & 100 & & & & & & & & & & \\
\hline $\mathrm{TX}$ & Papaya & Mexico & 100 & & & & & & & & & & \\
\hline $\mathrm{TX}$ & Papaya & Mexico & 100 & & & & & & & & & & \\
\hline TX & Papaya & Mexico & 100 & & & & & & & & & & \\
\hline $\mathrm{AZ}$ & Passion Fruit & unknown & 100 & & & & & & & & & & \\
\hline $\mathrm{AZ}$ & Passion Fruit & unknown & 100 & & & & & & & & & & \\
\hline $\mathrm{CA}$ & Passion Fruit & unknown & 100 & & & & & & & & & & \\
\hline $\mathrm{CA}$ & Passion Fruit & N. Zealand & 100 & & & & & & & & & & \\
\hline $\mathrm{CA}$ & Passion Fruit & N. Zealand & 100 & & & & & & & & & & \\
\hline $\mathrm{CA}$ & Passion Fruit & N. Zealand & 80 & California & 20 & & & & & & & & \\
\hline $\mathrm{CA}$ & Passion Fruit & N. Zealand & 40 & California & 60 & & & & & & & & \\
\hline $\mathrm{CA}$ & Passion Fruit & N. Zealand & n.a. & Mexico & n.a. & & & & & & & & \\
\hline
\end{tabular}


Appendix Table D-3 (continued). Wholesalers' sources of specialty tropical fruits, by fruit.

\begin{tabular}{|c|c|c|c|c|c|c|c|c|c|c|c|c|c|}
\hline $\begin{array}{c}\text { Wholesaler } \\
\text { location }\end{array}$ & Fruit & Source 1 & Percent & Source 2 & Percent & Source 3 & Percent & Source 4 & Percent & Source 5 & Percent & Source 6 & Percent \\
\hline $\mathrm{CA}$ & Passion Fruit & California & 60 & N. Zealand & 40 & & & & & & & & \\
\hline $\mathrm{CA}$ & Passion Fruit & California & 80 & N. Zealand & 20 & & & & & & & & \\
\hline $\mathrm{CA}$ & Passion Fruit & California & 50 & N. Zealand & 50 & & & & & & & & \\
\hline $\mathrm{CA}$ & Passion Fruit & California & 50 & N. Zealand & 50 & & & & & & & & \\
\hline $\mathrm{CA}$ & Passion Fruit & California & 33 & Florida & 33 & N. Zealand & 33 & & & & & & \\
\hline $\mathrm{CA}$ & Passion Fruit & unknown & 100 & & & & & & & & & & \\
\hline $\mathrm{CA}$ & Passion Fruit & unknown & 100 & & & & & & & & & & \\
\hline $\mathrm{CA}$ & Passion Fruit & California & 100 & & & & & & & & & & \\
\hline FL & Passion Fruit & Florida & n.a. & Mexico & n.a. & & & & & & & & \\
\hline FL & Passion Fruit & Florida & 50 & N. Zealand & 50 & & & & & & & & \\
\hline FL & Passion Fruit & Florida & 95 & N. Zealand & 5 & & & & & & & & \\
\hline FL & Passion Fruit & Florida & 100 & & & & & & & & & & \\
\hline FL & Passion Fruit & Florida & 100 & & & & & & & & & & \\
\hline FL & Passion Fruit & California & 40 & Florida & 50 & N. Zealand & 10 & & & & & & \\
\hline FL & Passion Fruit & Florida & 100 & & & & & & & & & & \\
\hline FL & Passion Fruit & Florida & 100 & & & & & & & & & & \\
\hline $\mathrm{IL}$ & Passion Fruit & N. Zealand & 90 & Florida & 10 & & & & & & & & \\
\hline IL & Passion Fruit & N. Zealand & 50 & California & 45 & Florida & 5 & & & & & & \\
\hline IL & Passion Fruit & C. America & 100 & & & & & & & & & & \\
\hline IN & Passion Fruit & Florida & 90 & unknown & 10 & & & & & & & & \\
\hline MA & Passion Fruit & S. America & 100 & & & & & & & & & & \\
\hline MA & Passion Fruit & N. Zealand & 60 & California & 20 & Florida & 20 & & & & & & \\
\hline MI & Passion Fruit & N. Zealand & 100 & & & & & & & & & & \\
\hline $\mathrm{NJ}$ & Passion Fruit & California & 100 & & & & & & & & & & \\
\hline NJ & Passion Fruit & unknown & 100 & & & & & & & & & & \\
\hline NY & Passion Fruit & Florida & 100 & & & & & & & & & & \\
\hline NY & Passion Fruit & Chile & 100 & & & & & & & & & & \\
\hline NY & Passion Fruit & Florida & 100 & & & & & & & & & & \\
\hline NY & Passion Fruit & S. America & 100 & & & & & & & & & & \\
\hline NY & Passion Fruit & Florida & 100 & & & & & & & & & & \\
\hline NY & Passion Fruit & Florida & 100 & & & & & & & & & & \\
\hline NY & Passion Fruit & Florida & 50 & California & 50 & & & & & & & & \\
\hline PA & Passion Fruit & Florida & 30 & N. Zealand & 70 & & & & & & & & \\
\hline PA & Passion Fruit & Florida & 100 & & & & & & & & & & \\
\hline SC & Passion Fruit & imports & 100 & & & & & & & & & & \\
\hline FL & Sugar Apple & Florida & 100 & & & & & & & & & & \\
\hline FL & Sugar Apple & Florida & 100 & & & & & & & & & & \\
\hline IL & Sugar Apple & Florida & 100 & & & & & & & & & & \\
\hline IL & Sugar Apple & Florida & 100 & & & & & & & & & & \\
\hline IN & Sugar Apple & Florida & 90 & unknown & 10 & & & & & & & & \\
\hline MA & Sugar Apple & unknown & 100 & & & & & & & & & & \\
\hline PA & Sugar Apple & unknown & 100 & & & & & & & & & & \\
\hline TX & Sugar Apple & Florida & 100 & & & & & & & & & & \\
\hline
\end{tabular}

